UNIVERSIDADE DE SÃO PAULO

FACULDADE DE FILOSOFIA, LETRAS E CIÊNCIAS HUMANAS DEPARTAMENTO DE LETRAS CLÁSSICAS E VERNÁCULAS PROGRAMA DE PÓS-GRADUAÇÃO EM LETRAS CLÁSSICAS

\title{
CRÍTON: TRADUÇÃO, ANÁLISE E COMENTÁRIOS
}

\author{
Mauro Armond Di Giorgi
}

(mauro@linuxmail.org)

Dissertação apresentada ao Programa de Pósgraduação em Letras Clássicas do Departamento de Letras Clássicas e Vernáculas da Faculdade de Filosofia, Letras e Ciências Humanas da Universidade de São Paulo, para a obtenção do título de Mestre em Letras.

Área de concentração: Grego

Orientador: Prof. Dr. Adriano Machado Ribeiro

\section{São Paulo}


Errata 
À Alessandra, minha companheira há 16 anos. 


\section{Agradecimentos}

À Alessandra Moura Velho, pelo amor, carinho, incentivo e paciência durante os nossos 16 anos de relacionamento.

Ao Prof. Dr. Adriano Machado Ribeiro, pelas inestimáveis contribuições para que esta dissertação se realizasse: desde o apoio à minha primeira tradução de um texto em grego, O elogio de Helena, em 2004, passando pela primeira versão da tradução do Críton, em 2005, e pela tradução da Apologia, em 2008, até a enésima leitura e crítica do presente trabalho. O rigor exigido na explicação de cada linha traduzida nestes textos criou em mim um gosto enorme pelo estudo da sintaxe grega. Este gosto traduziu-se nas centenas de notas que espalhei pela tradução.

À Amanda Perez Pinos, pela paciência, respeito e aguçado espírito

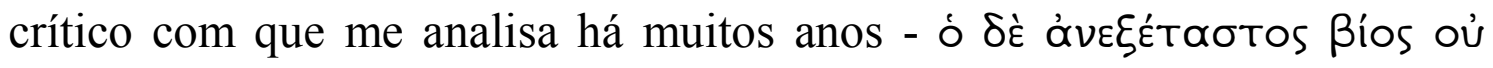

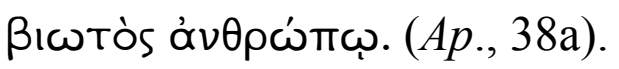

Ao Prof. Dr. Daniel Rossi Nunes Lopes, pelos comentários e críticas realizados durante o meu Exame de Qualificação, mas, principalmente, pela dedicação e generosidade demonstradas nas aulas de sábado que ministrou durante o ano de 2003, como complemento aos cursos regulares de Língua Grega I e II. Essas aulas foram fundamentais para o meu aperfeiçoamento posterior no estudo da língua grega.

Aos meus pais, por tudo que fizeram por mim, principalmente pelo amor e carinho com que me criaram.

Ao Prof. Dr. Roberto Bolzani Filho, pelos comentários e críticas realizados durante o meu Exame de Qualificação. Sua atenciosa e criteriosa leitura de minha tradução rendeu-me quase quatro meses de trabalho envolvendo correções e reelaborações. 


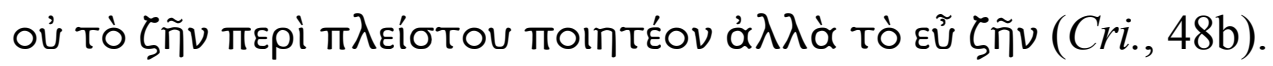




\section{RESUMO}

Esta dissertação tem dois objetivos principais: (1) efetuar um estudo introdutório, concentrando-se sobretudo no argumento do diálogo que se encontra em 49a-c e (2) apresentar uma tradução do Críton de Platão em português a partir do original em grego. Quanto à tradução, esta está entremeada de notas e comentários que visam: (a) explicar o meu entendimento acerca das funções exercidas pelas partículas, que são abundantes no texto em grego; (b) esclarecer a sintaxe dos trechos que considerei mais complexos; (c) fundamentar algumas das opções que adotei na tradução; (d) explicar algumas referências a nomes, lugares e trechos de obras citados no texto original; e, finalmente, (e) evidenciar alguns pontos do Criton que não são tratados diretamente nesta dissertação, mas que são objetos de estudo e discussão entre os comentadores de Platão. Quanto ao trecho 49a-c, Sócrates propõe nele um princípio que limita a retaliação em resposta a uma injustiça qualquer sofrida. $\mathrm{O}$ estudo que me propus a fazer consiste em (a) evidenciar algumas ambigüidades presentes na formulação de tal princípio e em (b) uma análise das interpretações de três importantes comentadores de Platão sobre este tema.

Palavras-chave: Críton, Sócrates, Platão, retaliação, tradução. 


\begin{abstract}
This dissertation has two main objectives: (1) to perform a introductory study concerning the argument of the dialogue which lies in the passage 49a-c and (2) to present a translation of Plato's Crito from the original text in Greek into Portuguese. With relation to the translation, it is interspersed with notes and commentaries whose intentions are: (a) to explain my understanding of the functions performed by the particles, which are plentiful in the text; (b) to clarify the syntax of the passages I considered more difficult; (c) to give support to some choices I adopted in the translation; (d) to explain some references to names, places and passages of other works mentioned in the original text; and, finally, (e) to point out some passages of the Crito with which I do not deal in this dissertation, but which are objects of study and discussion among the commentators on Plato. With relation to the passage 49a-c, Socrates proposes in it a principle that limits the retaliation in response to an injustice suffered. The study I intended to perform consists (a) in pointing out some ambiguities in the formulation of this principle and (b) in analyzing the interpretations of this passage performed by three important commentators on Plato.
\end{abstract}

Keywords: Crito, Socrates, Plato, retaliation, translation. 


\section{Lista de Siglas}

GP - Denniston, Greek Particles.

LSJ - Liddell, Scott e Jones, Greek-English Lexicon.

SMTGV - Goodwin, Syntax of the Mood and Tenses of the Greek Verb.

GG - Smith, Greek Grammar.

OCT - Duke, Hicken, Nicoll, Robinson e Stratchan, Platonis Opera I. 


\section{Sumário}

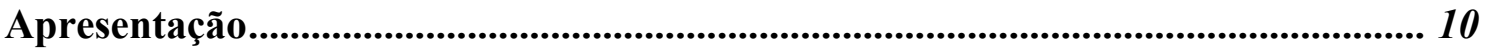

A retaliação no Críton .................................................................................................... 12

Introdução ……………............................................................................................................................... 12

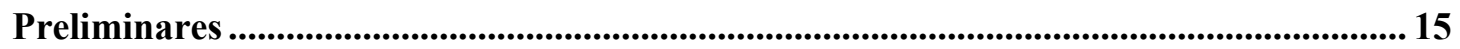

Não-retaliação ou retaliação moderada? .............................................................................. 20

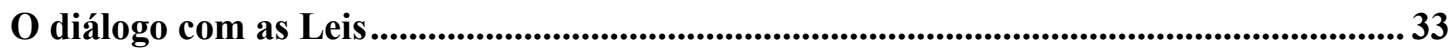

Conclusão ........................................................................................................................................... 47

Quadro sinótico dos trechos referenciados no capítulo ........................................ 48

Quadro sinótico dos princípios de não-retaliação propostos por Irwin e/ou Stokes ........51

Quadro sinótico dos princípios de não-retaliação propostos por Vlastos.............................52

Tradução do Críton............................................................................................. 53

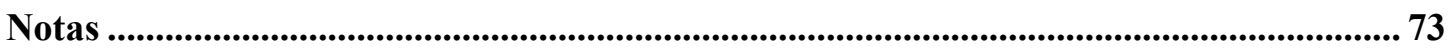

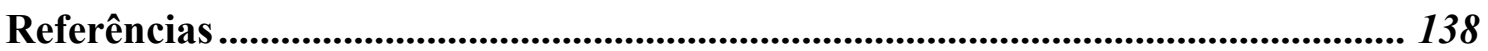

Anexo I - Texto do Críton em grego .................................................................... 142 


\section{Apresentação}

Esta dissertação tem dois objetivos principais: apresentar uma tradução do Criton de Platão a partir do original em grego e efetuar um estudo do trecho 49a-c, de acordo com a paginação estabelecida por Henricus Stephanus. Para tanto, dividi-a em dois capítulos.

No primeiro deles, "A retaliação no Críton", farei uma pequena introdução ao diálogo em questão, procurando, principalmente, diferenciálo dos demais diálogos ditos socráticos, além de expor dois importantes temas de discussão entre os comentadores que o envolvem, justificando, por fim, por que escolhi o último deles, o trecho $49 \mathrm{a}-\mathrm{c}$, como objeto de análise. Em seguida, apresentarei um pequeno resumo da parte inicial do Criton, comentando algumas passagens, com o intuito de destacar a importância do trecho 49a-c na argumentação de Sócrates. Na seção seguinte, efetuarei uma análise detalhada do trecho em questão, evidenciando algumas ambigüidades presentes na construção do princípio formulado por Sócrates que limitaria a retaliação diante de uma injustiça sofrida, e apresentarei as interpretações que Vlastos, Irwin e Stokes dele fizeram. Percorrerei, em seguida, o restante do diálogo, verificando a coerência de tais interpretações com a argumentação das Leis de Atenas. Discutirei, depois, mais duas outras possíveis interpretações formuladas por Stokes, enfatizando, além da coerência, a aderência delas ao diálogo, apresentando, por fim, uma conclusão.

O capítulo 2 será dedicado à tradução do Críton a partir do texto estabelecido pela OCT. A tradução será entremeada de notas e comentários cujos objetivos fundamentais são:

a) explicar tanto o meu entendimento acerca das funções cumpridas por muitas das partículas, que são abundantes no texto, quanto a sintaxe dos 
trechos que julguei mais complexos, de modo que um estudante que já tenha cursado de quatro a cinco semestres de língua grega possa apreciar as sutilezas das construções de Platão;

b) esclarecer algumas opções que adotei na tradução;

c) explicar algumas referências diretas ou indiretas a personagens, lugares, trechos de obras e eventos que deveriam ser relativamente evidentes para os primeiros leitores do diálogo, mas que dizem muito pouco para os que procuram estudá-lo atualmente;

d) destacar passagens relevantes no diálogo que não foram tratadas de modo mais profundo no primeiro capítulo da dissertação. 


\section{A retaliação no Críton}

\section{Introdução}

O Criton é considerado um dos primeiros diálogos de Platão ${ }^{1}$. Dramaticamente ele se vincula ao período que cobre o julgamento e a morte de Sócrates. É, quanto à cena dramática, o terceiro num total de quatro composições (os dois primeiros são o Eutifron e a Apologia; o último, o Fédon). No Eutífron, as acusações contra Sócrates são mencionadas, tornando-se o ponto de partida para a discussão filosófica de que o dito diálogo trata; na Apologia, Sócrates apresenta a sua defesa perante o tribunal de Atenas; o Críton, por sua vez, mostra Sócrates aguardando na prisão o dia da execução de sua pena; finalmente, no Fédon, temos o testemunho que Fédon dá a um amigo do último dia da vida de Sócrates. O Criton apresenta, juntamente com o Eutifron, a estrutura mais simples possível para o gênero, pois possui apenas dois interlocutores em mimese direta. Difere, no entanto, muito do padrão geral seguido pelos primeiros diálogos, ditos aporéticos ou socráticos. Nesses, via de regra, Sócrates propõe a seus interlocutores que definam alguma virtude (a piedade no Eutífron, a temperança no Cármides, a justiça na República I, v.g.) e, sempre que recebe uma resposta, normalmente dada de modo

\footnotetext{
${ }^{1}$ Estou seguindo a ordem cronológica estabelecida por Vlastos (VLASTOS, 1995b, pp 135). Tarrant (1995 apud STOKES, pp 212 n. 20), no entanto, defende que o Críton, dada a abundância de adjetivos verbais, que são raros em outras obras platônicas anteriores à República, seja considerado também um trabalho tardio de Platão. Stokes, por sua vez, argumenta que a abundância de adjetivos verbais, e outras formas correlatas (ver nota em 49a4), se justificaria pela própria natureza do diálogo: "The Crito is par excellence the dialogue that discusses what ought to be done". (Tarrant, H. 'Plato's Euthydemus and the faces of Socrates', Prudentia 47, 4-17).
} 
confiante pelo interlocutor, que supõe conhecê-la ${ }^{2}$, aquele a submete a questionamentos que finalmente a levam a ser rejeitada. O processo é, então, repetido, com uma nova definição sendo proposta pelos mesmos ou por outros interlocutores, até que, tendo sido uma a uma rejeitadas, a outra parte admita não ter o conhecimento que supunha ter sobre tal virtude

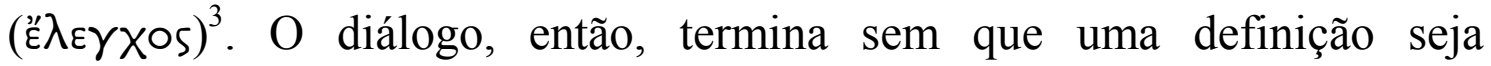
apresentada nem mesmo por Sócrates, já que ele afirma não ter conhecimento algum.

No Criton, nada disso ocorre. Sócrates aguarda na prisão o dia de sua execução. Seu amigo (cujo nome é o título do diálogo) avisa-o que tal dia se aproxima e propõe-lhe que fuja da prisão com a ajuda de alguns outros companheiros. Ambos passam a deliberar, então, tendo como base princípios morais, se Sócrates deve aceitar a idéia da fuga, contrariando a vontade da cidade, que o condenou, ou se ele deve permanecer na prisão e acatar a sua pena, mesmo considerando que sua condenação tenha sido injusta. Trata-se, assim, de decidir, por meio de uma deliberação, qual das ações é moralmente justificada.

As posições defendidas por Sócrates no Criton são freqüentemente comparadas às que ele defende na Apologia. Isso se deve não somente por este preceder imediatamente aquele no que diz respeito à cena dramática mas também por ambos terem sido escritos, conforme julga a maioria dos comentadores de Platão, em datas não muito distantes ${ }^{4}$. Algumas dessas posições, no entanto, nem sempre parecem conciliáveis. No Críton, por exemplo, Sócrates, por meio da personificação das Leis de Atenas, defende

\footnotetext{
${ }^{2}$ Conforme Sócrates narra na Apologia (Ap., 21b-22e).

${ }^{3}$ Não havia um nome para este processo de refutação, mas Sócrates costumava descrevê-lo como ËㅊำXOS (refutação). VLASTOS, 1995b, pp 2.

${ }^{4}$ Vide nota 1.
} 
(51b-c) o que Finley (FINLEY, 1995) chama de obrigação política de um cidadão, ao afirmar que um homem, após ter aceitado viver durante toda a sua vida em uma pólis como cidadão, concordou também em respeitar as leis e as decisões dos tribunais quaisquer que estas fossem. Na Apologia, por sua vez, Sócrates afirma (29b-c) que, se os membros do tribunal the propusessem um acordo em que o livrariam de todas as acusações, na condição de que ele deixasse de filosofar, ele, apesar de toda a estima que dizia ter por Atenas, obedeceria ao Deus, quem ele considerava ter-lhe concedido a sua missão filosófica, e não aceitaria tal acordo. Esta aparente contradição evidenciada por estas duas passagens é um dos mais importantes temas de discussão entre os estudiosos do Críton, principalmente por parte dos que se ocupam em estudar a figura de Sócrates, já que boa parte dos comentadores consideram que, nestas duas obras, Platão teria apresentado um Sócrates que se assemelharia muito ao Sócrates histórico. Não tratarei, nesta dissertação, deste tema, principalmente porque seria impossível fazê-lo sem que um estudo profundo da Apologia fosse realizado em conjunto, algo que fugiria muito do escopo daquilo que me propus a fazer.

Há, no entanto, no Críton, um outro importante ponto de discussão entre os comentadores que merece destaque. Sócrates (49a-c), partindo do princípio de que ninguém deve, deliberadamente, agir de modo injusto, deriva um princípio que limita a retaliação em resposta a uma injustiça qualquer sofrida. Para Vlastos (VLASTOS, 1991), tal princípio seria um rompimento radical com a moral vigente no mundo grego de então. Para Irwin (IRWIN, 1995), no entanto, o mesmo princípio era, na verdade, ambíguo e, portanto, mereceria um estudo mais detalhado, o que foi feito, recentemente, por Stokes (STOKES, 2005). 
Por estar na base da argumentação de Sócrates e, posteriormente, das Leis de Atenas contra a fuga, o que já cobre boa parte do diálogo; pela importância do tema em si para os estudiosos da teoria da ação em Platão, em particular; e, principalmente, devido à possibilidade de verificarmos, com base na análise do texto do Críton exclusivamente, o quão coerentes e aderentes ao diálogo são as visões destes comentadores sobre este tema, detive-me nesta questão como ponto central de análise nesta dissertação.

\section{Preliminares}

Críton, depois de comunicar a Sócrates que o dia de sua execução era iminente, propõe-lhe que sem demora aceite a ajuda que ele e seus amigos lhe oferecem para fugir da prisão. Para sustentar seu argumento, Críton menciona o seu temor de ter a sua reputação questionada, pois muitos acreditariam que ele poderia tê-lo salvado se quisesse gastar dinheiro, além da grande perda pessoal que sofreria, pois considera Sócrates um amigo inigualável. Em resposta, Sócrates faz pouco caso do questionamento que fariam da reputação de Crito, isto é, do que a "maioria" (oi mo $\lambda \lambda \circ$ oí$^{\text {) }}$ pensaria acerca de sua morte, replicando que os "mais capazes" (oi

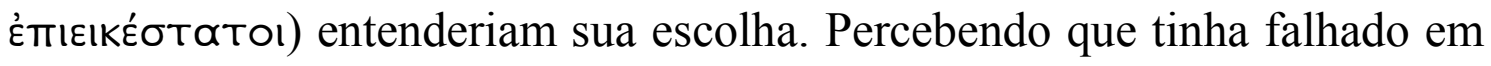
sua primeira investida, Críton tenta averiguar se a razão da resistência de Sócrates se deve ao fato de ele não querer prejudicar seus amigos, que certamente terão de enfrentar algum tipo de retaliação por ajudá-lo a fugir. A resposta de Sócrates, confirmando que isso também o preocupava, dá um novo alento a Críton, que lança uma nova série de argumentos contra a sua permanência na prisão (45c6-45d9). Ele, em suma, acusa Sócrates de não estar agindo corretamente, pois, acatando sua pena, este está beneficiando os seus inimigos, que o querem morto, e prejudicando a si mesmo, os seus 
amigos e, principalmente, seus filhos, que o querem vivo. É digno de nota que "beneficiar os inimigos e prejudicar os amigos" é exatamente o oposto do que o ateniense médio da época de Sócrates, alguém da "maioria", entendia por "agir com justiça", Considerando que havia conseguido minimizar o temor de Sócrates quanto à retaliação que sofreriam e que também havia demonstrado a injustiça que acarretava sua recusa, Críton exorta-o (46a4-a9) a deixar-se persuadir por ele:

"Vamos, decida-se - ou melhor, não é mais hora de decidir, mas de estar decidido. Só há uma decisão, pois na noite que se aproxima isso já deverá estar feito. Se ainda esperarmos, a fuga será impraticável e não será mais possível empreendê-la. Vamos, Sócrates, de qualquer maneira, deixe-se persuadir por mim e de forma alguma faça de outro modo." 6

O ímpeto do amigo e a acusação de estar atuando de modo contrário ao justo fazem Sócrates concordar em discutir a possibilidade da fuga, mas ele adianta que não se deixará persuadir por apelos emocionais:

“Temos, então, de examinar se devemos fazer isso ou não, porque eu não agora pela primeira vez mas, de fato, sempre tenho sido do tipo tal que não me deixo persuadir por nada que

\footnotetext{
${ }^{5}$ DOVER, pp 180-181.

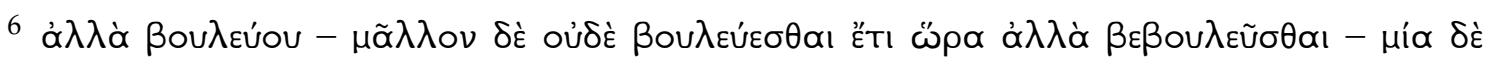

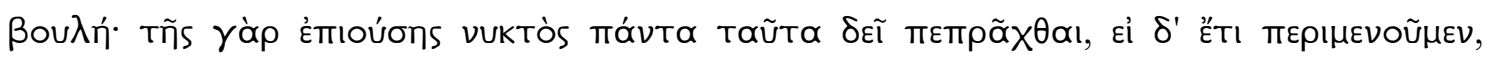

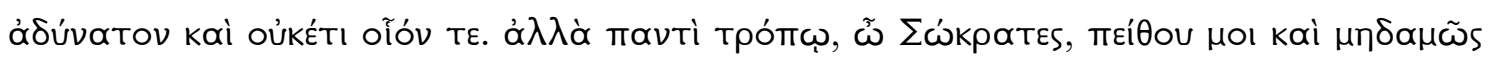

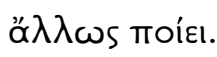


esteja sob meu comando a não ser pelo raciocínio que se mostrar melhor para mim quando raciocino. ${ }^{7}$

Sócrates completa, em seguida, que sua decisão de permanecer na prisão é baseada em princípios que ele sempre defendeu durante sua vida, os quais são de conhecimento de Críton; e que a fuga só será considerada uma alternativa viável se, nas circunstâncias em que se encontram, puderem produzir argumentos que refutem os anteriores. Ambos, então, passam a analisar se isto ocorre com os argumentos lançados há pouco por Críton, começando pelo valor que ele afirma ter o juízo da maioria.

Dessa análise, Sócrates faz Críton conceder que

a) os juízos dos homens mais sábios são os que devem ser levados em conta, mas não os dos tolos, isto é, que o que importa é a qualidade intelectiva de quem os emite, não a sua quantidade numericamente preponderante (47a9-11);

b) um atleta deve ouvir os juízos de seu treinador, que é quem conhece o que deve ou não ser feito para que se atinja a excelência atlética, mas não os juízos de quaisquer outros (47a12b12);

c) um atleta que faz o oposto disso sofrerá um dano em seu corpo $(47 \mathrm{c} 1-\mathrm{c} 7)$

d) analogamente, a respeito das questões morais, deve-se temer e obedecer os conselhos do especialista moral, caso exista um, mas não os de quaisquer outros $(47 \mathrm{c} 8-\mathrm{d} 6)$;

e) não vale a pena viver com o corpo corrompido (47e4-e6);

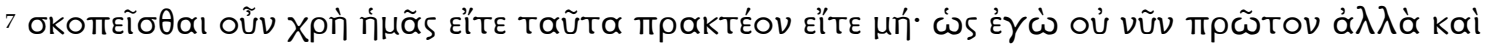

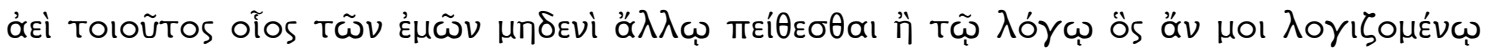

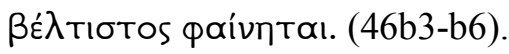


f) a $\underline{\operatorname{alma}}^{8}$ é ferida pelo ato injusto, mas beneficiada pelo justo $(47 \mathrm{e} 7)$;

g) a alma é muito mais importante que o corpo (47e8-48a2);

h) não vale a pena viver com a alma corrompida.

Tendo feito estas concessões, Críton admite que não se deve dar atenção ao juízo da maioria, mas somente ao do especialista e, por conseguinte, à verdade. Devem ser feitas algumas observações acerca destes argumentos, pois eles serão retomados adiante.

Primeiramente, para que se aceite (c), é preciso que se considere que o juízo de quem não é um especialista em determinado assunto a respeito do mesmo é falso e danoso, o que é, no mínimo, rigoroso demais. Depois, por ter concedido (c), Críton não precisaria aceitar (d): a idéia de que a virtude é um conhecimento constitui um dos grandes paradoxos do Sócrates de Platão e, conforme vemos nos diálogos ditos Socráticos, ela não era facilmente assimilada por seus interlocutores. Finalmente, a analogia entre o corpo e a alma sugere que as ações injustas prejudicam esta do mesmo modo que as atitudes não saudáveis fazem com aquele, o oposto ocorrendo mutatis mutandis com as ações justas e as atitudes saudáveis. Deste modo, pode-se perguntar quantos e que tipos de atos injustos são precisos para que a alma se corrompa definitivamente, pois não é somente com uma única atitude não saudável que o corpo se corrompe. Por exemplo, é sabido que beber em demasia não é saudável, mas talvez seja somente com um hábito prolongado de se embriagar que se chegue à corrupção do corpo. Tal questionamento não é feito por Críton e tal dúvida

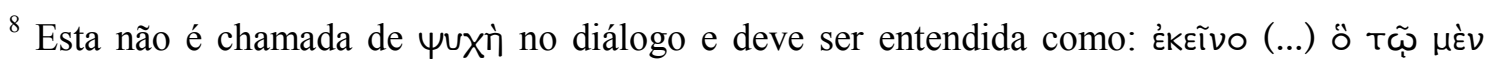

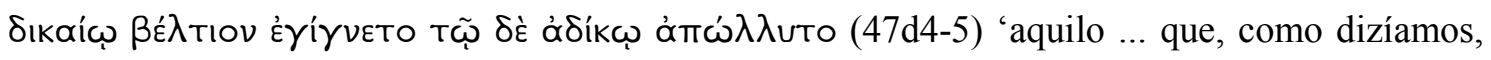
torna-se melhor com o justo, mas é destruído com o injusto'. Sempre que nos referirmos a alma nesse sentido, o termo será sublinhado.
} 
não é esclarecida pelo diálogo. Além disso, como notou Irwin ${ }^{9}$, o fato de o ato justo beneficiar e do injusto prejudicar, em última instância, o agente, dado por (f), torna-se um ponto importante a ser analisado no argumento de Sócrates, pois ele estará obrigado a demonstrar no desenrolar do diálogo que o que até então ele considera justo a fazer - sofrer a pena que lhe foi imposta - é também um benefício para si mesmo, e, reciprocamente, que a fuga, além de injusta, é maléfica.

Sócrates passa, em seguida, a tratar do outro argumento de Críton: "embora o juízo da maioria não seja de grande valia, ela pode sentenciarnos à morte". Para refutá-lo, Sócrates utiliza (h) para conseguir que

i) o que importa não é viver, mas viver bem (48b5); e termina fazendo Críton aceitar também que

j) viver bem é o mesmo que viver bela e justamente (48b7).

A partir de (j), Sócrates deriva, em 48b11-c2, o critério segundo o qual a questão da fuga será debatida entre ambos:

"Devemos, portanto, examinar isso a partir daquilo com que concordamos: se é justo ou não que eu tente sair daqui sem a permissão dos atenienses. E, se isso se mostrar justo, tentemos, caso contrário, desistamos. ${ }^{\mathrm{I}{ }^{\circ}}$

Com a concordância de Críton em relação ao critério adotado, Sócrates indica como a questão será examinada:

\footnotetext{
${ }^{9}$ IRWIN, pp 45.

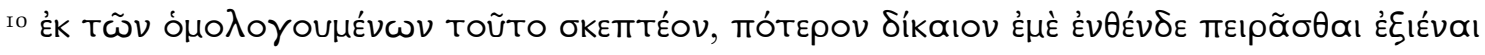

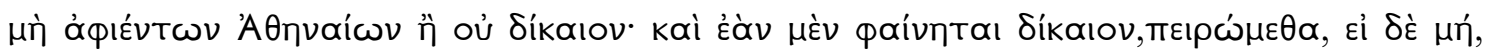

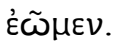


"Assim, observe o princípio da investigação, se este lhe for dito com senso, e tente responder a questão como considerar melhor. ${ }^{\text {II" }}$

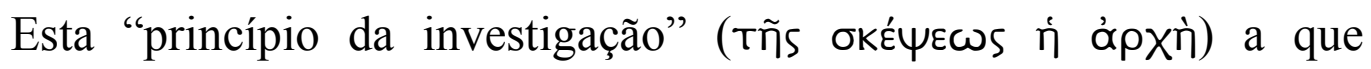
Sócrates se refere e que será construído a partir de outros mais elementares no trecho 49a4-49c11, será o objeto de análise das seções seguintes.

Para facilitar a sua análise e futuras referências, o trecho será apresentado na íntegra e seus principais argumentos serão sublinhados e numerados.

\section{Não-retaliação ou retaliação moderada?}

So. Afirmamos que, de modo algum, devemos cometer uma injustiça deliberadamente ou que, de algum modo, devemos, mas, de outro, não?(I) Ou de modo algum cometer uma injustiça, porque é injusto, é belo e bom, como muitas vezes nós também anteriormente concordamos? (II) Ou todos os princípios com as quais concordávamos antes foram descartados nestes poucos dias e, anteriormente, Críton, como agora se evidencia, nós mesmos (49b), homens de idade, não notamos que, embora conversássemos seriamente um com o outro, em nada diferíamos de crianças? Ou acima de tudo é assim como então se costumava dizer: se a maioria afirmar ou não, ou melhor, se tivermos ainda que sofrer algo mais difícil que isso ou mais fácil, não obstante, cometer uma injustiça,

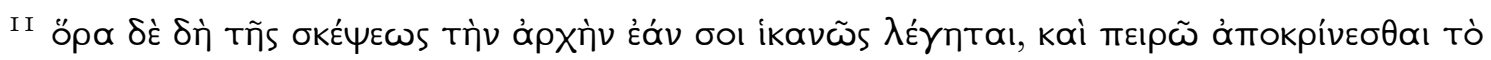

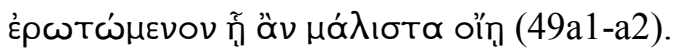


porque é injusto, vem a ser ruim e vergonhoso para quem a comete, de qualquer maneira (III)? Afirmamos isso ou não?

Cr. Afirmamos.

So. De modo algum se deve, então, cometer uma injustiça $($ (IV).

Cr. Certamente não.

So. Nem, portanto, revidar com uma injustiça se sofrer uma

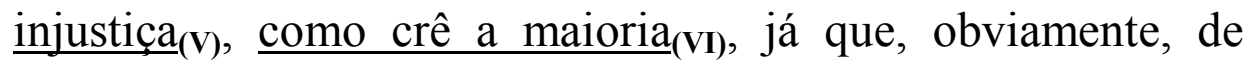
modo algum se deve cometer uma injustiça.

Cr. Aparentemente não $_{(\text {VII })}$. (c)

So. E quanto a isso aqui: deve-se, Críton, fazer mal a alguém ou não $($ VIII)?

Cr. Certamente não se deve, Sócrates.

So. E isso: é justo revidar com um mal, se sofrer um mal, $\underline{\text { como afirma a maioria, ou injusto }}_{(\mathbf{I X})}$ ?

Cr. De forma alguma.

So. Pois, presumo, fazer mal aos homens em nada difere de cometer uma injustiça $(\mathbf{X})$.

Cr. Você diz a verdade.

So. Não se deve, portanto, nem revidar com uma injustiça nem fazer mal a nenhum dos homens, nem mesmo se vier a sofrer qualquer coisa da parte deles $(\mathbf{X I )}$.

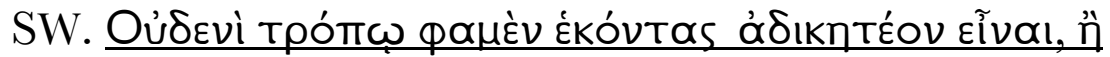

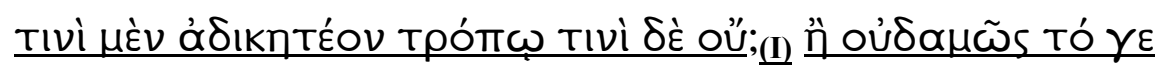

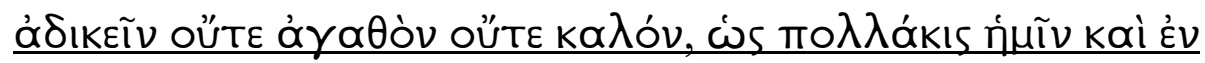

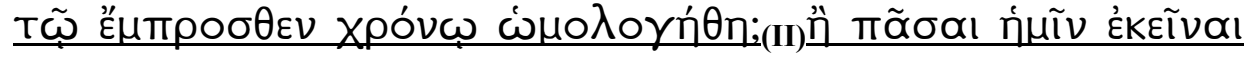
ai 


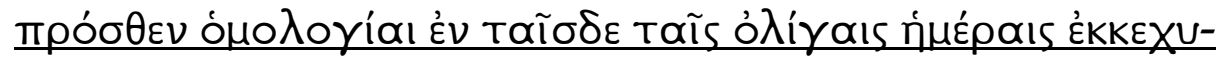

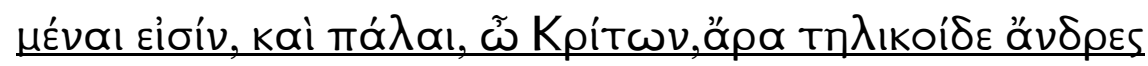

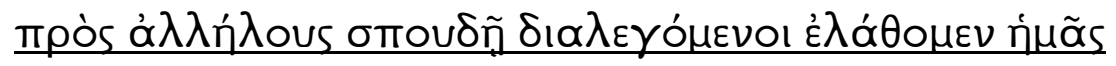

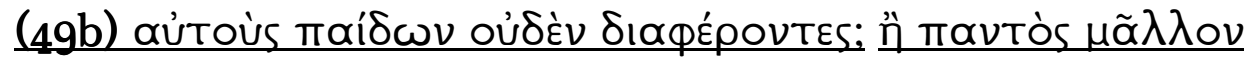

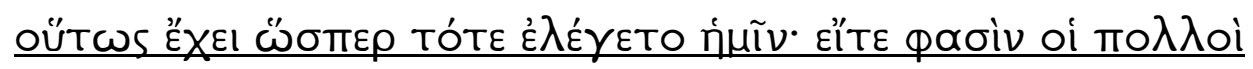

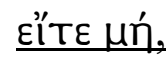

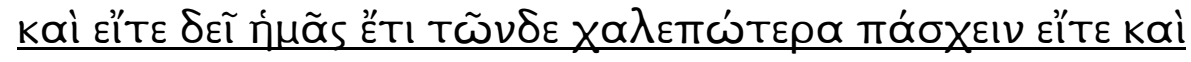

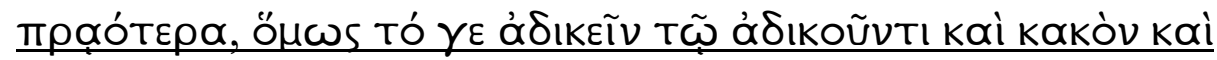

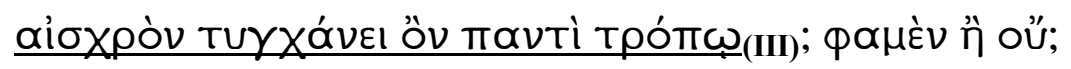

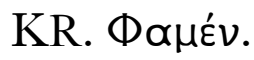

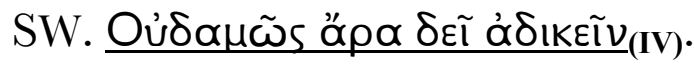
KR. Ou่ $\delta \tilde{n} \tau \alpha$.

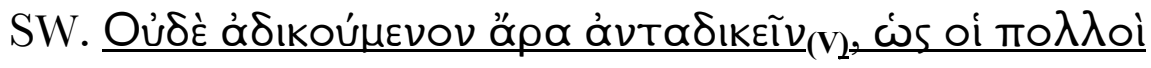

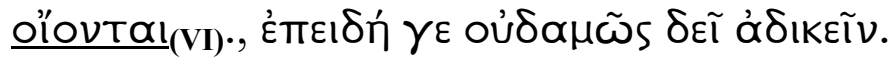

KR. OỦ páiveTal ${ }_{(\mathrm{VII})}$. (c)

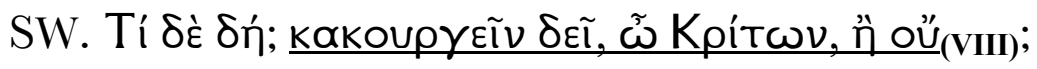

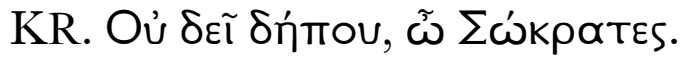

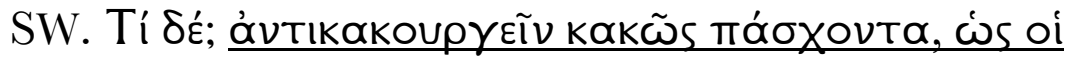

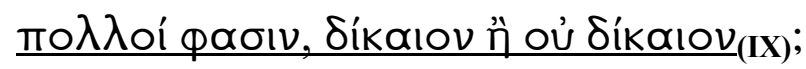

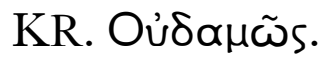

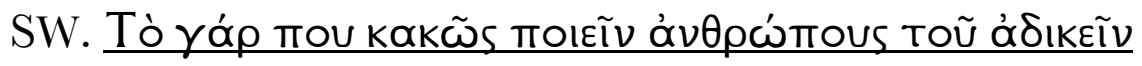

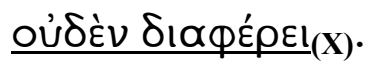

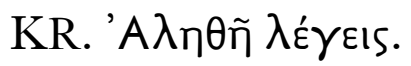

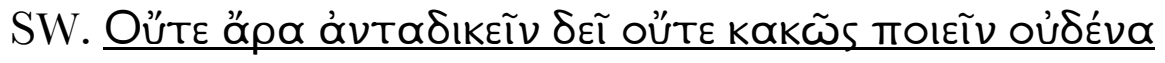

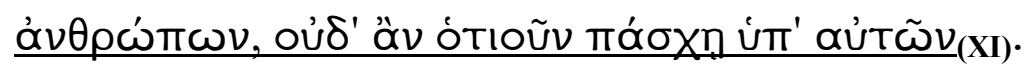


No trecho $(\mathrm{I})^{12}$, Sócrates simplesmente indaga a Críton se a proibição de se cometer uma injustiça deliberadamente deve ser absoluta. No trecho (II), por sua vez, ele o relembra que anteriormente ambos já haviam concordado que cometer uma injustiça não era de modo algum nem "belo"13" nem "bom" 14". No trecho (III), por fim, Sócrates praticamente exige que Críton conceda a proibição absoluta que ele apenas sugeria em (I) ou que, no mínimo, apresente razões para ter aceitado os argumentos de (II) em outros tempos, mas rejeitá-los na ocasião em se encontram.

De (II), podemos concluir modo tollente que se algo é "belo" e "bom", ele não é o resultado de uma injustiça. Além disso, parece pressuposto tanto em (II) quanto em (III) que não se deve agir deliberadamente visando algo "ruim ${ }^{15}$ " ou "feio" ${ }^{16 "}$ (ou "vergonhoso"), pois nem Sócrates nem Críton levantam qualquer objeção quanto a isso no diálogo todo.

Podemos, portanto, dizer que a concessão desejada no trecho (I), que aparece como uma conclusão em (IV) ${ }^{17}$, Sócrates a deriva assim:

(a) Não se deve agir visando algo "ruim" ou "vergonhoso" deliberadamente. (Pressuposto em II e III)

(b) Cometer uma injustiça é, de todo modo, "ruim" e "vergonhoso" para quem a comete. (II e III)

\footnotetext{
${ }^{12}$ Há um quadro sinótico com todos os trechos e princípios referenciados neste capítulo no final deste.

${ }^{13} \mathrm{k} \alpha \lambda$ ós.

${ }^{14}$ àjờòs.

${ }^{15}$ kakòs.

${ }^{16}$ aioxpòs.

${ }^{17}$ Embora o argumento (IV) omita o adjetivo Ékóvtas, deixa-o subentendido. Ver nota $49 \mathrm{~b} 7$.
} 
(c) De modo algum se deve cometer uma injustiça deliberadamente. (IV)

O princípio (IV), no entanto, apresenta uma ambigüidade séria: como não há definição explícita de justiça no diálogo, não é possível afirmar se a injustiça a que ele se refere deve ser tomada absolutamente ou considerando-se as circunstâncias em que ela ocorrer. Este mesmo problema está presente nos qualificantes "belo", "bom", "ruim" e "feio" ("vergonhoso").

Para ilustrar a diferença das duas concepções, tomemos um exemplo do Livro I da República (R, 331a ss). Nesta passagem, Céfalo afirmou que a justiça consistia, entre outras coisas, em pagar o seus débitos. Sócrates, para refutá-lo, criou um cenário com a seguinte seqüência de ações:

i. W toma emprestado a espada de Z.

ii. $\mathrm{Z}$ torna-se insano.

Se adicionássemos (IV), tomado em sua forma absoluta, ao princípio proposto por Céfalo, teríamos que conceder que $\mathrm{W}$ deveria devolver a espada para $Z$, já que $\mathrm{W}$ deve uma espada a Z. Porém, se (IV) fosse aplicado, levando-se em conta as circunstâncias acima, concluiríamos, como fez Sócrates, que $\mathrm{W}$ não deveria devolver a espada a $\mathrm{Z}$, pois a injustiça que $\mathrm{W}$ estaria cometendo a $\mathrm{Z}$, não devolvendo a sua espada, seria um mal menor que o que poderia ocorrer caso $\mathrm{Z}$ tivesse sua espada de volta, nas condições em que ele se encontra. Esta mesma ambigüidade está presente em (II), (III) e será espalhada pelos argumentos que seguem.

Quanto a Críton, ele certamente deveria, a partir do que vimos nos argumentos (a)-(h) comentados na seção anterior, conceder que se deve evitar ao máximo a prática de uma injustiça, já que isso prejudicaria a alma do mesmo modo como o que é não saudável faz com o corpo. Porém não 
haveria razões suficientes para que ele acatasse a proibição absoluta, pois, como vimos, as analogias tanto entre o corpo e a alma quanto entre a doença e a injustiça não são suficientes, por exemplo, para descartar um ato injusto feito esporadicamente. Há, porém, ao menos uma razão forte para que Críton acate (IV): se não o fizesse, o fato de Sócrates cometer uma injustiça, permanecendo na prisão, como Críton considera, deixaria de ser um argumento suficiente para que Sócrates aceitasse a idéia de fuga.

Com base no argumento (IV), Sócrates deriva o (V). Da mesma forma como vimos em (IV), ao dizer que não se deve revidar com uma injustiça $X$ uma injustiça sofrida $Y$, Sócrates não especifica se a injustiça $X$ deve ser tomada absolutamente ou relativamente às circunstâncias em que se sofre a injustiça Y. Irwin ${ }^{18}$, estudando este trecho, forneceu dois princípios que satisfazem o argumento (V), mas explicam diferentemente a relação entre as injustiças $\mathrm{X}$ e Y mencionadas acima:

O princípio R1 diz que:

1. Se A cometeu uma injustiça Y em B;

2. Se $B$ fizer $X$ a $A$ e $X$ for considerado uma injustiça, caso $A$ não tenha feito $\mathrm{Y}$ a $\mathrm{B}$;

3. Então, B não deve fazer X a A.

O princípio R2 diz que:

1. Se A cometeu uma injustiça $\mathrm{Y}$ em B;

2. Se B fizer $X$ a A e $X$ for considerado uma injustiça, caso $A$ não tenha feito $\mathrm{Y}$ a $\mathrm{B}$;

3. Então, o fato de ter sofrido $Y$ não é uma razão suficiente para que $B$ faça $X$ a $A$.

\footnotetext{
${ }^{18}$ IRWIN, pp 361 n. 47.
} 
$\mathrm{O}$ princípio $\mathrm{R} 1$, por tomar cada ato absolutamente, proibiria qualquer ato retaliatório, como, por exemplo, uma punição por um delito cometido ou mesmo a autodefesa.

A título de comparação, cabe notar que, apesar de severo, R1, restrito a agressões físicas, no entanto, difere muito do seguinte princípio cristão, que também proíbe qualquer ato retaliatório,

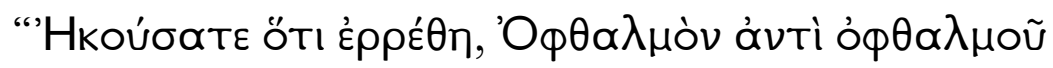

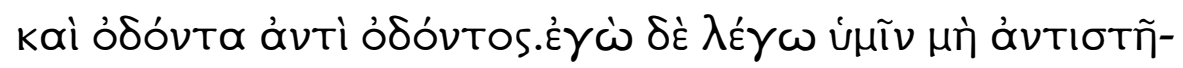

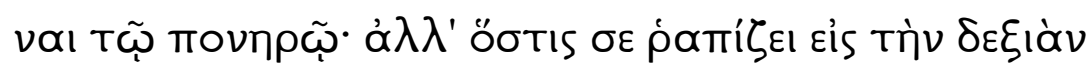

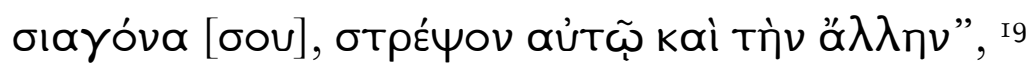

pois R1 de modo algum requer que quem sofra uma agressão continue a sofrê-la, ou até que a estimule, com o intuito de ensinar o seu agressor que sua ação é errada ou de, simplesmente, envergonhá-lo.

O princípio R2, ao contrário, permite atos retaliatórios, como agir em defesa própria, mas exige que se apresentem outras justificativas. No caso, o direito de cada um de preservar sua integridade física. Notemos que em (VII), Críton mostra-se reticente em aceitar o princípio $(\mathrm{V})^{20}$ - ou o que quer que tenha entendido dele - o qual, segundo Sócrates, é o contrário do que crê a maioria (VI). As ambigüidades de (IV) e (V) não nos permitem avaliar nem os motivos da reticência de Críton nem por que Sócrates julga que a maioria não os aceitaria.

Permaneçamos, por enquanto, somente com esses dois princípios, R1 e R2, como possíveis sentidos para (V) e sigamos com a análise dos próximos argumentos.

\footnotetext{
I9 Novum Testamentum, Evangelium secundum Matthaeum Chapter 5, v 38-40. "Ouvistes porque foi dito: olho por olho, dente por dente. Mas eu vos digo: não te oponhas a quem é mal, mas a quem quer que te bata na tua face direita, oferece-lhe também a outra."
}

${ }^{20}$ Ver nota em $49 \mathrm{c} 1$. 
No argumento (VIII), Sócrates parece querer expandir o alcance do

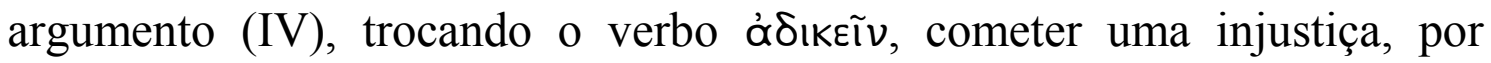

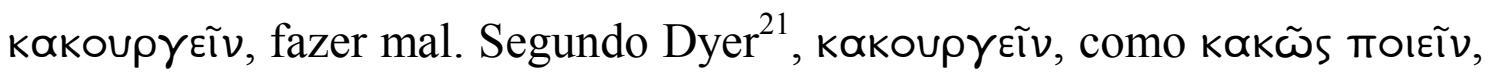

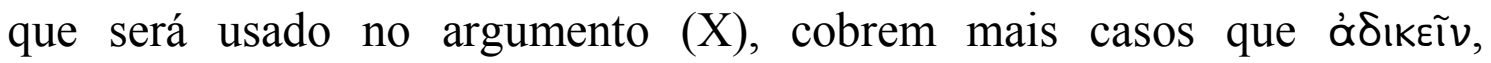
incluindo também ferimentos corporais sem levar em conta se são ou não

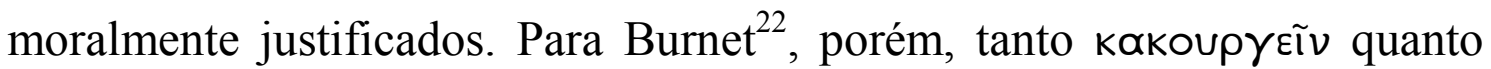

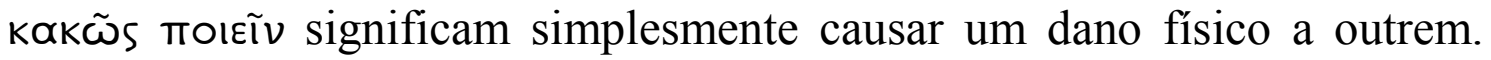
Por último, Emilyn-Jones ${ }^{23}$ interpreta os verbos de maneira oposta à de Burnet: para ela ambos significam apenas realizar qualquer espécie de ato

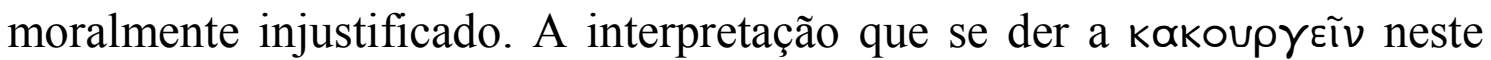
argumento, como veremos, dará origem a interpretações completamente distintas de todo o trecho em questão, de modo a influenciar, inclusive, o entendimento da segunda parte do diálogo.

Sócrates deriva, em seguida, o argumento (IX) do (VIII) de maneira análoga à utilizada para derivar o (V) do (IV). É digno de nota a semelhança estrutural que os pares (IV)/(V) e (VIII)/(IX) apresentam. Comparemos, esquematicamente, os dois ${ }^{24}$ :

- $(\mathrm{IV}) /(\mathrm{V})$

Já que (argumento (IV))

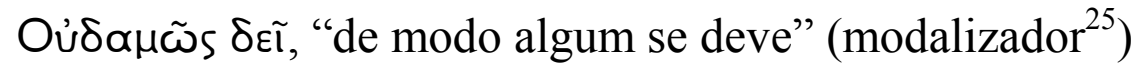

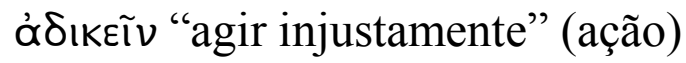

\footnotetext{
${ }^{21}$ PLATO, 1998, pp 132.

${ }^{22}$ PLATO, 1979, pp 279.

${ }^{23}$ PLATO, 1999, pp 72.

${ }^{24}$ Adaptado a partir do que fez Stokes (STOKES, pp. 105 ss.)

${ }^{25}$ Estou usando o termo "modalizador" lato senso, como fez Palmer (PALMER, pp 51 ss): além das noções básicas de possibilidade ou necessidade, engloba qualquer sistema modal que indique o grau de comprometimento do falante com aquilo que ele diz.
} 
então (argumento(V))

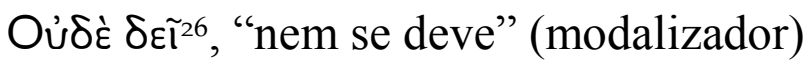

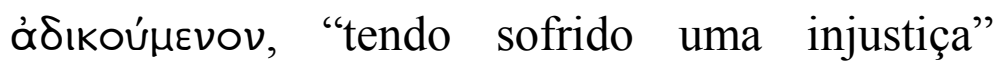
(sofrimento)

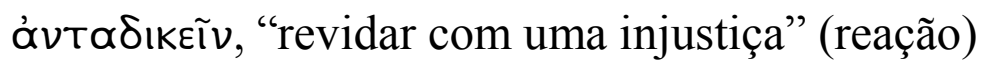

- $(\mathrm{VIII}) /(\mathrm{IX})$

Já que (argumento (VIII))

Oủ $\delta \varepsilon \tilde{\imath}$, "não se deve" (modalizador)

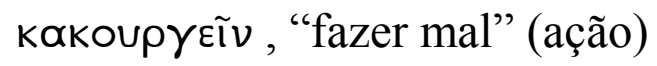

então (argumento (IX))

oủ Síkøıov, "não é justo que" (modalizador)

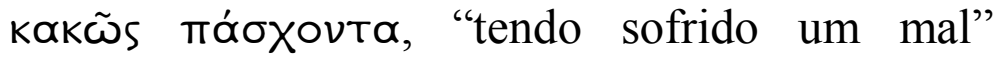
(sofrimento)

ávTıKakoupyeĩv, "revidar com um mal" (reação)

A simetria estrutural evidente entre os argumentos sugere que notemos também as dissemelhanças entre os termos usados em cada par e tentemos entender qual foi a razão dessas escolhas. Há dois casos que merecem uma atenção mais detalhada.

O primeiro diz respeito aos modalizadores utilizados nos argumentos (V) e (IX): enquanto que no argumento (V) Sócrates usou a forma "não se deve", em (IX) ele preferiu a forma "não é justo que". A meu ver, podemos explicar as variações como um refinamento no argumento de Sócrates: "não se deve" simplesmente proíbe, ao passo que "não é justo que" nos dá a causa da proibição, pois, conforme o que ambos acordaram (48b11-c2), numa deliberação, o que deve ser feito deve subordinar-se ao que é justo.

${ }^{26} \delta \varepsilon \tilde{\text { I }}$, embora não explicitado, está subentendido. 
O segundo diz respeito aos verbos utilizados nas partes que chamei de "ação", "sofrimento" e "reação". Em (V), Sócrates usou o verbo áరıкยĨv na voz ativa para marcar a "ação"; o particípio do mesmo verbo na

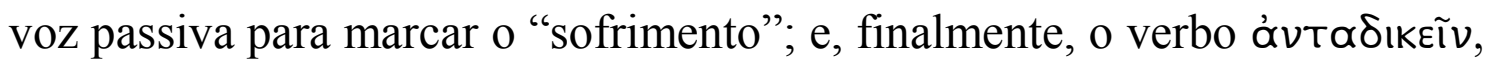

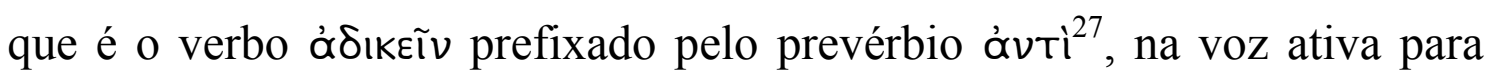
marcar a "reação". Já em (IX), ele utilizou os verbos kakoupyeĩv e

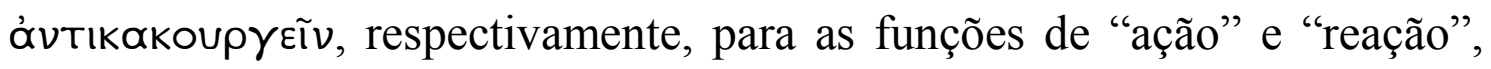
mas, para indicar o "sofrimento", estranhamente, onde se esperava

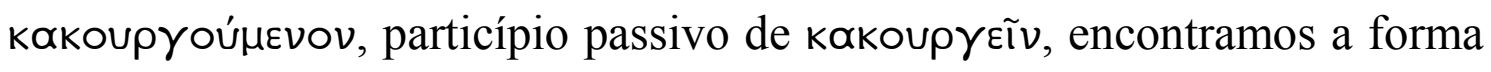

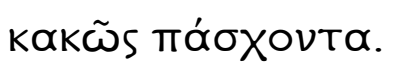

Stokes $^{28}$, que estudou detalhadamente a passagem, forneceu um

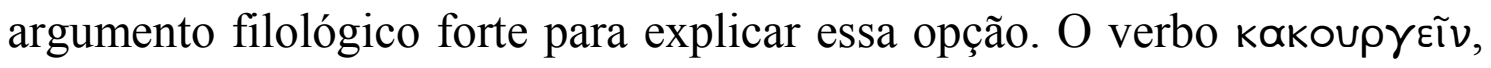
significando fazer um mal moralmente injustificado a alguém, é um verbo intransitivo no período clássico da língua grega, não admitindo a

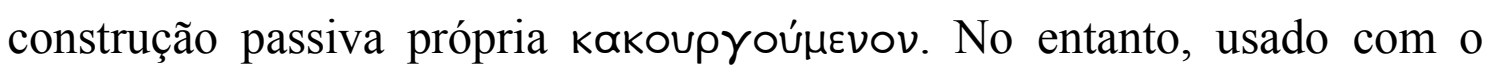
sentido de ferir ou causar um dano físico, como interpretou Burnet acima,

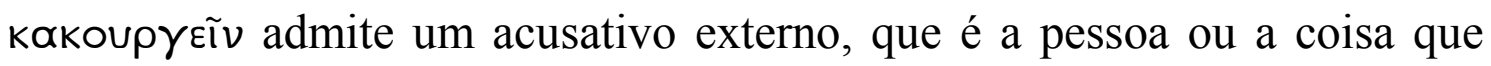
sofre a ação, e, portanto, a construção passiva. Logo, se Sócrates tivesse

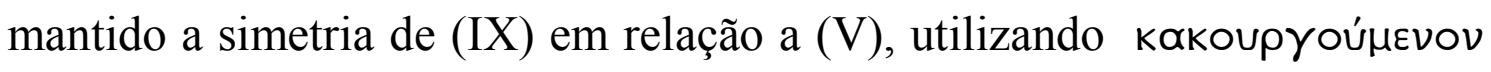

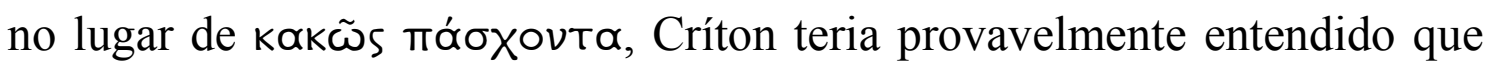
não se deveria revidar com um dano físico um dano físico recebido. Se, porém, fosse esse o sentido que Sócrates tinha em mente, não haveria

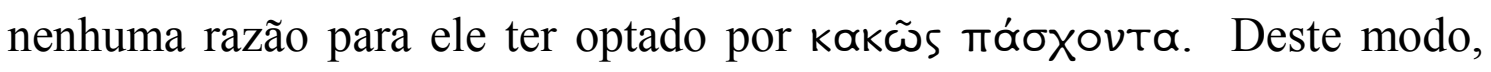

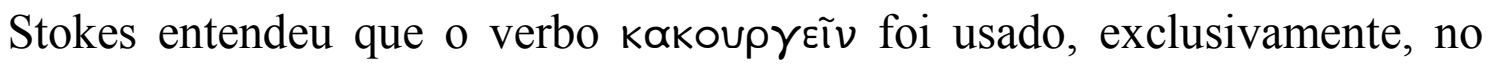

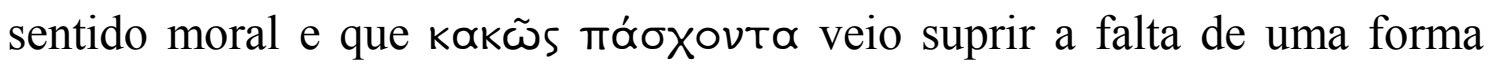

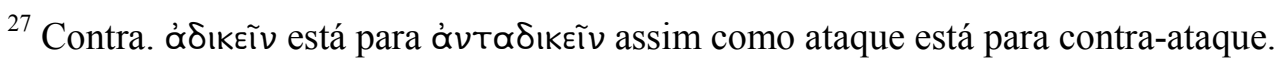

${ }^{28}$ STOKES, pp. 101-105
} 
passiva do tal verbo com esse sentido, já que o verbo máoXẼ̃v significa "sofrer".

$\mathrm{Na}$ visão de Stokes, portanto, o argumento (X), no qual Sócrates

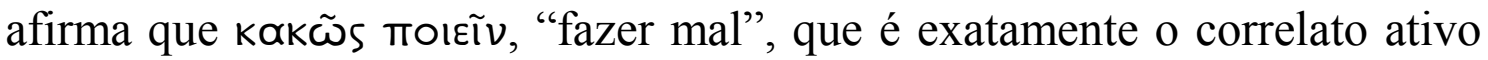

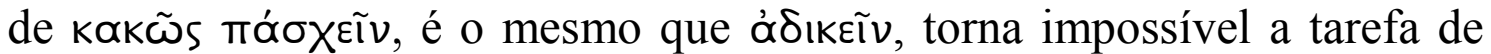
diferenciar os argumentos (V) e (IX) no âmbito do diálogo. Além disso, como o argumento (XI) não é mais que uma síntese dos argumentos (V) e (IX) as ambigüidades trazidas por (V) passam a ser de (IX) e, conseqüentemente, de (XI) também.

Esta, porém, não é a interpretação que Vlastos fez de (VIII) e (IX) ${ }^{29}$. Tomando, diferentemente de Stokes, (X) e (XI) como pontos de partida, em

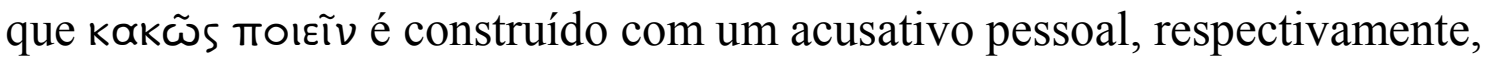

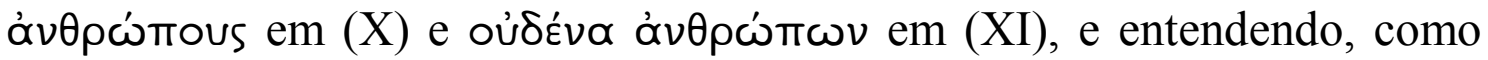

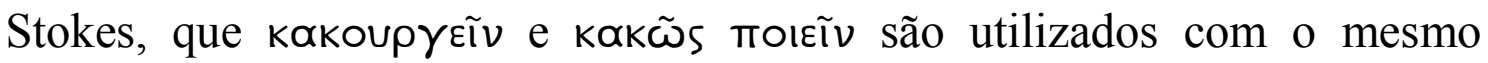
sentido, respectivamente, em (VIII) e (X), Vlastos considerou que o

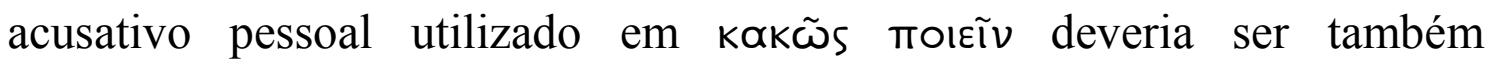

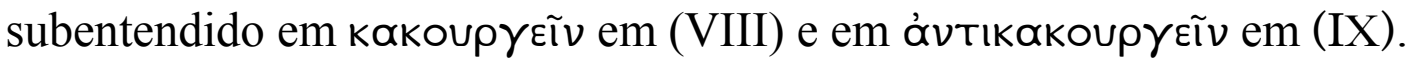

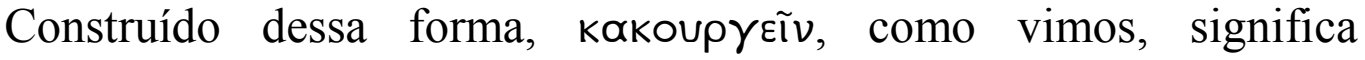
simplesmente "causar um dano físico a alguém". A favor do entendimento

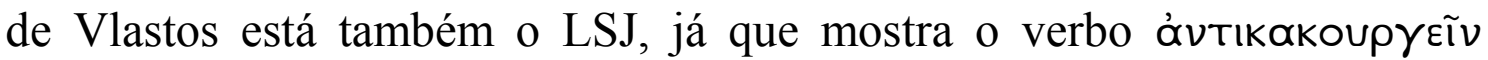
como sendo transitivo, construído com o acusativo pessoal, e cita esta passagem do Críton em questão como exemplo.

Cabe ressaltar que, mesmo percorrendo o caminho feito por Vlastos,

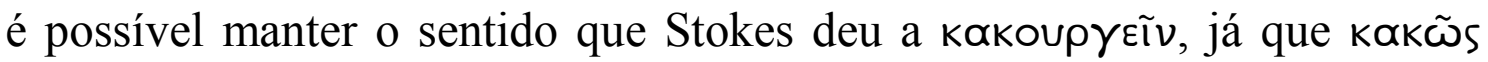
ToเєĨv pode ser usado para se referir tanto a danos moralmente injustificados quanto a danos físicos simplesmente. Para isso, bastaria que,

\footnotetext{
${ }^{29}$ VLASTOS, 1991, pp. 194.
} 
ao invés de um acusativo pessoal ligado diretamente ao verbo, se utilizasse o mesmo acusativo precedido da preposição $\pi \varepsilon \rho i ́$, como o mesmo Platão

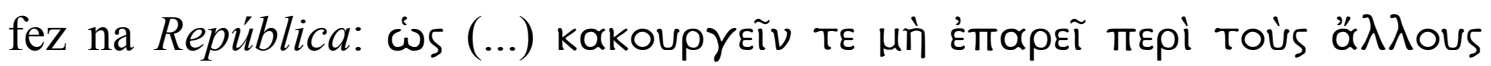
то入і́та $\varsigma^{30}$.

Segundo a interpretação de Vlastos, no entanto, (VIII) e (IX) devem ser entendidos, respectivamente, como "não se deve causar um dano físico a outrem" e "não se deve revidar com um dano físico um dano físico sofrido", o que os torna complementares em relação a (IV) e (V). Seguindo Vlastos, (IX) proibiria, por exemplo, até mesmo a autodefesa se esta dependesse de um gesto mais enérgico para se concretizar.

Vlastos, pouco depois, suavizou o entendimento de (IX) da seguinte forma: o dano físico a ser evitado seria

... any morally avoidable evil - any evil which is not purely incidental to the execution of a non-malicious intent, as in the case of self-defense (where harm is inflicted on an aggressor solely to prevent him from causing wrongful harm) or that of punishment (where infliction of the evil of the penalty Socrates takes to be moral therapy for wrongdoer (G. 480A-D, 525B) and/or retribution and deterrence (G. 525A-527A) ${ }^{31}$.

Como (XI), relembremos, sintetiza (V) e (IX), há, seguindo Vlastos, duas possibilidades interpretativas para tal princípio. $\mathrm{Na}$ primeira, que chamaremos de N1, o princípio (XI) seguiria a versão mais forte de (IX), proibindo qualquer revide que implicasse um ato injusto ou um dano físico ao agressor. Na segunda, que chamaremos de N2, (XI) seguiria a versão mais fraca de (IX), que permite a autodefesa e as punições judiciais.

\footnotetext{
$3^{30}$ (...) e de modo que não incite (os guadiões) a agir injustamente em relação aos outros cidadãos. (R., 416d1).

${ }^{31}$ VLASTOS, 1991, pp. 196 n. 50.
} 
Resumamos as posições dos dois comentadores. Para Stokes ${ }^{32},(\mathrm{~V})$, (IX) e (XI) simplesmente proíbem que se revide com uma injustiça uma injustiça recebida. Nada, contudo, afirmariam acerca do que seria um revide injusto:

Given these alternative readings of a veto on unjust retaliation for injustice suffered, what, at the end of the injustice-argument at Crito 49a4-c11, do the two speakers know about each other's views on what it would mean to commit injustice in return for injustice? The answer to that is virtually nothing. The questions put and the assents given are so potentially polysemous that fine though they sound, their informational content is low $^{33}$.

$\mathrm{Na}$ opinião de Stokes, portanto, as ambigüidades apontadas neste trecho sempre existiram, mesmo para os primeiros leitores do diálogo, ou seja, para ele, R1 e R2, ao menos, sempre foram interpretações plausíveis para o princípio (XI).

Para Vlastos, por outro lado, os princípios (V), (IX) e (XI) implicam na rejeição da lex talionis, não importando se se interpreta o princípio (XI) como N1 ou como N2. Eles teriam, portanto, diferentemente da interpretação defendida por Stokes, um conteúdo bastante forte. Mas que razão Sócrates fornece para que se aceite a interpretação de Vlastos?

There is no satisfactory answer to this question anywhere in Plato's Socratic dialogues. (...) The one thing that is made clear in this passage - and this is what we must settle for - is Socrates' intuition that true moral goodness is incapable of doing intentional injury to others, for it is inherently beneficent, radiant in its operation, spontaneously communicating goodness to those who come in

\footnotetext{
${ }^{32}$ E também para Irwin, que o precedeu nesta análise.

${ }^{33}$ STOKES, pp. 76.
} 
contact with it, always producing benefit instead of injury, so that the idea of a just man injuring anyone, friend or foe, is unthinkable ${ }^{34}$.

Vlastos não se ocupou das ambigüidades apontadas em (V). Quando Irwin as publicou (1995), ele já havia falecido (1991). Porém é digno de nota que, em N2, ele parece ter R2 em mente, já que, na autodefesa, por exemplo, seria permitido infligir ferimentos ao agressor que seriam injustificados caso nenhuma agressão ocorresse. Porém, na justificativa acima, o princípio que melhor se adequaria parece ser o R1.

\section{O diálogo com as Leis}

Como Platão não escrevia proposições simplesmente, mas diálogos, cabe questionar o que o restante do Criton tem a dizer sobre estas interpretações. Mais especificamente: que interpretações do princípio (XI), dentre as que levantamos até agora, seriam consistentes com os argumentos das Leis de Atenas? R1, R2, N1, N2 ou nenhuma delas?

Para tentar responder esta pergunta, voltemos ao diálogo. Lembremos que, logo após apresentar os princípios que analisamos acima, Sócrates consegue que Críton conceda mais um:

"sempre que alguém estiver de acordo com outrem em relação a certas coisas, sendo elas justas, ele deve cumprir o acordo.35" $(49 \mathrm{e} 6-7)(\mathrm{XII})^{36}$

Finalmente, levando em consideração os princípios (XI) e (XII), ele pede a Críton que responda:

\footnotetext{
${ }^{34}$ VLASTOS, 1991, pp. 196-197.

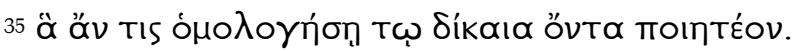

${ }^{36}$ Continuarei numerando os argumentos do mesmo modo como fiz no trecho $49 \mathrm{a}$-c.
} 
"Nós, indo embora daqui sem ter persuadido a cidade, fazemos mal a alguns, mais precisamente, aos que menos devemos

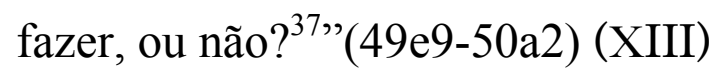

Esta pergunta, Críton declarou que não podia respondê-la. Para alguns, ele não o fez porque não era intelectualmente capaz de acompanhar o raciocínio de Sócrates. Para outros, a pergunta é suficientemente vaga para que, no mínimo, Sócrates se disponha a explicá-la melhor. Porém, antes de formar qualquer juízo precipitado, deve-se notar que Críton, como vimos anteriormente, tinha argumentado que era a recusa de Sócrates em aceitar a fuga que prejudicaria quem ele menos deveria prejudicar. Declarar-se incapaz de respondê-la, portanto, é perfeitamente compatível com o respeito que ele devia ter pela capacidade argumentativa de Sócrates e com o seu argumento inicial, que, lembremos, não foi ainda desafiado.

Diante da declaração de Críton, Sócrates, introduz, personificadas, as Leis de Atenas: elas dialogarão com Críton e um Sócrates ${ }^{38}$ que hipoteticamente teria aceitado a idéia de fuga, na tentativa de obter de ambos uma reposta à pergunta acima.

Em 50a10-b6, as Leis perguntam a Sócrates ${ }_{\mathrm{H}}$ :

"Diga-me, Sócrates, o que você tem em mente fazer? Não é verdade que, com esse ato ${ }^{39}$ que você empreende, você planeja destruir, tanto quanto lhe cabe, a nós, as leis, e a cidade como $\underline{\text { um todo }}{ }^{40}$ ? (XIV)

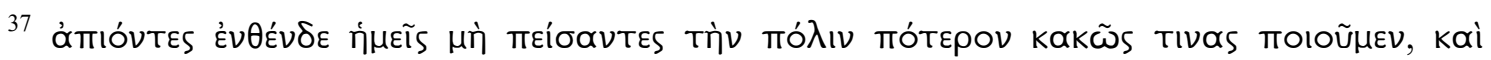

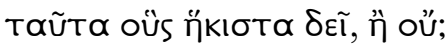

${ }^{38}$ Daqui em diante Sócrates $_{\mathrm{H}}$.

${ }^{39}$ Isto é, a fuga da prisão.

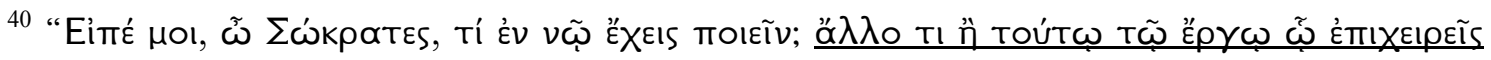

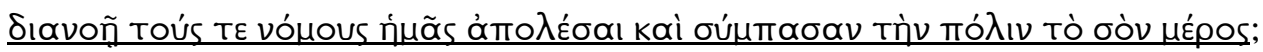


Em suma, as Leis, personificadas, igualaram em (XIV) a idéia de fuga de Sócrates $_{\mathrm{H}}$ a uma tentativa, dentro das possibilidades deste, de destruí-las. Sem contestar (XIV), Sócrates ${ }_{\mathrm{H}}$, em seguida, justifica o ato em questão, com o consentimento de Críton, da seguinte forma (50c1-2):

"Sim, tentaremos isso, porque a cidade foi injusta conosco e não aplicou corretamente a justiça. ${ }^{41}$ " (XV)

Se estivessem argumentando contra a fuga, entendendo (XI) como $\mathrm{N} 1$, não haveria mais necessidade de as Leis argumentarem sobre a injustiça da ação de Sócrates $_{\mathrm{H}}$, já que N1 proíbe que se cause um dano físico a qualquer pessoa. Note-se que a personificação das Leis é de importância fundamental para que N1 faça sentido em (XIV), pois (X) e (XI), recordemos, restringem-se somente ao maltrato de homens.

Como as Leis continuam argumentando, devemos rejeitar a idéia de que elas argumentam contra um entendimento de (XI) que acomode N1.

Se estiverem, no entanto, argumentando contra a fuga, entendendo (XI) como R1, as Leis necessitam apenas mostrar que a fuga da prisão é uma ato injusto, pois, como vimos, tal princípio proíbe absolutamente a prática de uma injustiça, não importando o que se tenha sofrido.

As Leis lembram-nos, então, (50c4-5), sem insistir muito no ponto por ora, que Sócrates $_{\mathrm{H}}$, tentando a fuga, estaria quebrando um acordo prévio que tinha justamente com elas, o de respeitar as decisões judiciais. Embora tal argumento seja forte, já que poderia contar como uma violação do princípio (XII), elas preferem avançar em outra direção, tentando mostrar que justificar (XIV) com (XV) é injusto per se. Assim, em 50e251a7, após conseguirem a concordância de ambos de que as leis sobre o

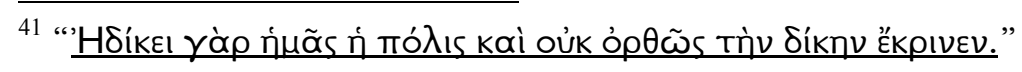


casamento e as que garantiam os direitos das crianças à educação eram boas, lançam três argumentos seguidos:

"Bem, depois que nasceu e foi nutrido e educado, você podia dizer, em primeiro lugar, que, a seu ver, não era nosso filho ou escravo, nem você nem seus ancestrais? (XVI) E se isso é assim, você considera que o justo exista a partir de uma igualdade para você e para nós, mais precisamente, aquilo que tentarmos fazer-lhe você considera que seja justo também para você fazer de volta em represália? (XVII) Ou, por um lado, como era evidente, em relação ao seu pai e ao seu senhor, se por acaso teve um, o justo não existia a partir de uma igualdade, de modo que você também fizesse de volta em represália precisamente aquilo que sofresse, ou seja, não era justo que, se falavam mal de você, você respondesse nem que, se fosse atacado, contra-atacasse nem que fizesse muitas coisas semelhantes a estas; mas, por outro lado, em relação à pátria e às leis, como se envidencia, será permitido a você fazer tudo $\underline{\text { isso, de modo que, se nós tentarmos destruí-lo, considerando }}$ que isso seja justo, você também, tanto quanto seja capaz, tentará destruir-nos, às leis e à pátria, e dirá que, fazendo isso, pratica ações justas, você que verdadeiramente cuida da virtude $^{42}$ ? (XVIII)

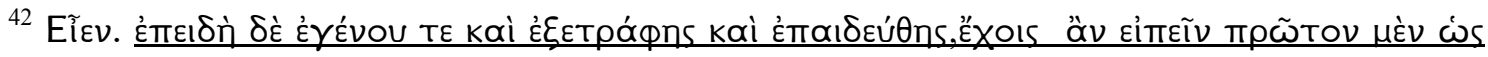

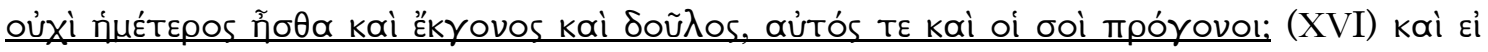

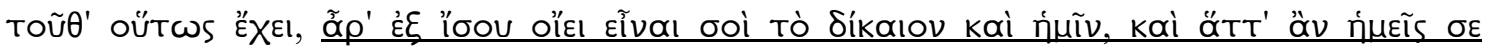

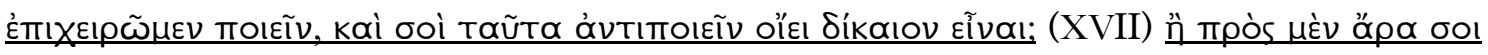

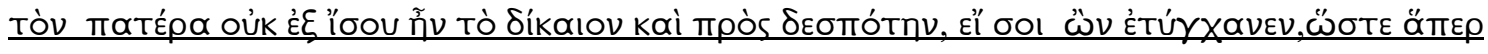

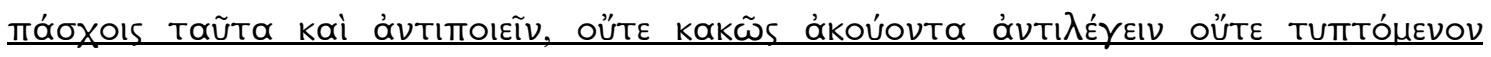


$\mathrm{O}$ argumento (XVI) visa estabelecer que as Leis devem ser consideradas por todos, incluindo os escravos, como se, pelo menos, fossem pais ou senhores, o que não foi contestado nem por Críton nem por Sócrates $_{\mathrm{H}}$, mesmo porque não era possível que soubessem que tipo de analogia elas fariam, uma vez que, com relação aos pais, por exemplo, são múltiplas as possibilidades: "assim como se obedece aos pais, deve-se obedecer às leis", "assim como se é grato aos pais, deve-se ser grato às leis" etc.

No argumento (XVII), a analogia conseguida em (XVI) é esclarecida: está no nível dos direitos que uma parte tem em relação à outra, ou seja, mais especificamente, no direito de uma parte fazer que a outra sofra algo não ainda especificado, sem que esta tenha direito de replicá-lo.

Com o argumento (XVIII), as Leis querem ter certeza de que a analogia foi bem entendida por ambos, isto é, que fique claro que assim como o filho ou escravo devem ouvir as críticas e sofrer, sem replicar, os castigos de seus pais ou senhores, todos devem sujeitar-se aos castigos que as Leis, quando elas considerarem serem justos, lhes apliquem.

Como ambos não retrucam estes argumentos, estão aceitando que em (XIV) há, como conseqüência destes, uma injustiça contra as Leis. Portanto, se as Leis argumentassem contra a fuga, entendendo (XI) como $\mathrm{R} 1$, a injustiça de Sócrates $_{\mathrm{H}}$ estaria demonstrada e o diálogo entre eles não necessitaria ser prolongado. O mesmo aconteceria se interpretassem (XI)

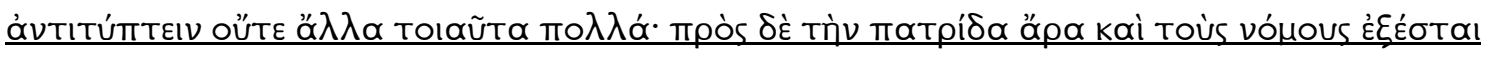

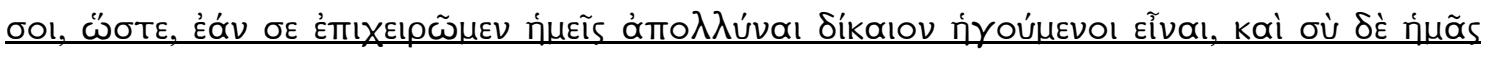

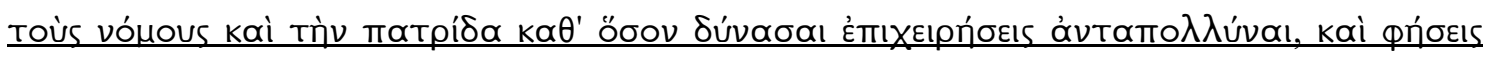

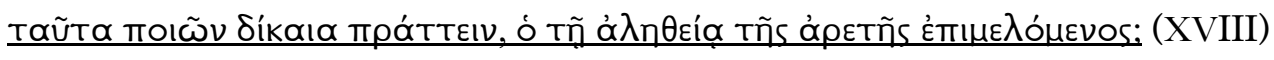


como N2, pois a autodefesa permitida por tal princípio estaria, em vista dos mesmos argumentos, também deslegitimada.

Se (XI) fosse tomado como R2, no entanto, o fato de (XIV) ser injusto contra as Leis só seria suficiente para derrubar a idéia de fuga se não houvesse razões adicionais que justificassem empreendê-la, pois, como vimos, tal princípio diz somente que o fato de se ter sofrido uma injustiça $Y$ não é um argumento suficiente para que $\mathrm{Y}$ seja revidada com uma outra injustiça $X^{43}$.

Antes de lidar com as justificativas em prol da fuga, as Leis reforçam

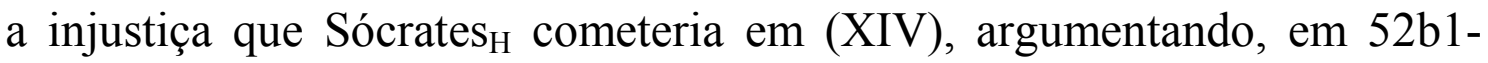
53a9, desta vez de forma exaustiva, que ele estaria quebrando o acordo tácito e justo que tinha firmado com a comunidade: o de respeitar as decisões judiciais para poder viver como cidadão. Sócrates ${ }_{\mathrm{H}}$, portanto, estaria violando também o princípio (XII).

Como Críton já tinha lançado outros argumentos em prol da fuga anteriormente, as Leis, supondo que eles agora também são apoiados por Sócrates $_{\mathrm{H}}$, precisam mostrar que, ainda assim, eles são insuficientes para justificar (XIV) e a violação de (XII).

Primeiramente, Críton tinha acusado Sócrates de agir de modo injusto, abandonado a si mesmo, quando poderia ser salvo (45c6-7). As Leis, por sua vez, contra-argumentam que a pena de morte havia sido uma escolha de Sócrates:

"E ainda, foi-lhe permitido no seu julgamento propor o exílio como pena, se desejasse, e fazer, na ocasião, com o

\footnotetext{
${ }^{43} \mathrm{X}$ e Y tomadas como injustiças absolutamente, sem que uma influencie na prática da outra.
} 
consentimento da cidade, precisamente isso que você tenta fazer agora sem o consentimento dela. ${ }^{44, "}(52 \mathrm{c} 4-6)$

Depois, quando pediu que Sócrates não temesse a fuga, afirmando que ele poderia ser bem recebido em muitos lugares, e em particular na Tessália (45b7-c5), Críton apresentou uma possível refutação ao argumento que Sócrates tinha fornecido na Apologia (Ap. 37c ss) para recusar o exílio como pena alternativa, já que ele disse então estar certo de que seria expulso de qualquer cidade em que continuasse a sua "missão filosófica". Tal missão, que Sócrates afirmou ter recebido do deus, recordemos, ele mesmo a apresentou (Ap., 29b-d) como uma justificativa suficiente para que ele não aceitasse, caso the tivesse sido proposto pelos juizes, um acordo ou sentença em que saísse livre do julgamento, na condição de que abandonasse a filosofia:

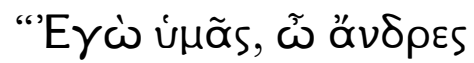

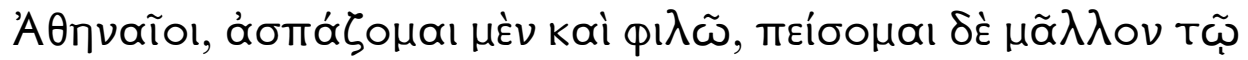

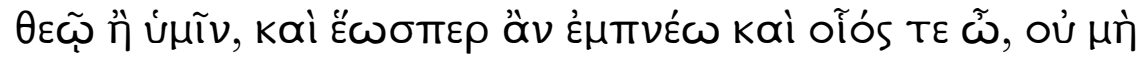

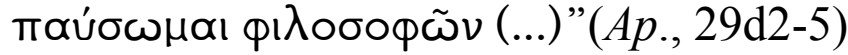

"Eu, atenienses, os saúdo e amo, mas obedecerei mais ao deus que a vocês e, enquanto eu respirar e for possível, de modo algum eu pararei de filosofar" (...)

Quando, então, as Leis perguntam retoricamente a Sócrates $_{\mathrm{H}}$ em 53a9-b1

"Transgredindo tudo isso e cometendo aí um erro, que bem fará a si mesmo ou ao seus amigos? ${ }^{45,}$,

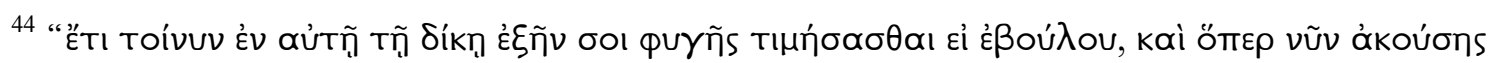

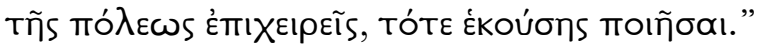

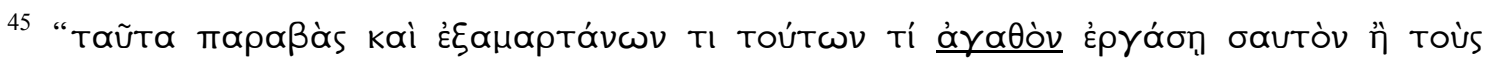

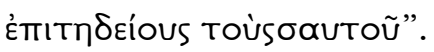


estão, a meu ver, reconhecendo que tal argumento, se não for derrubado, pode justificar a fuga de Sócrates $\mathrm{H}_{\mathrm{H}}$.

Para derrubá-lo, primeiramente, as Leis argumentam que, se Sócrates $_{\mathrm{H}}$ fosse para as cidades que têm boas leis, não seria aceito, pois ele chegaria como um inimigo, já que seria considerado um corruptor de leis (53b5-c3). Se fosse para as que têm leis ruins, não poderia filosofar, pois não teria como argumentar que a virtude e a justiça valem muito em lugares onde não se prezam esses assuntos (53c3-8). Se fosse à Tessália, em particular, poderia até ser bem acolhido pelos amigos de Críton, mas somente se não os incomodasse, o que implicaria ele não poder examinálos. Caso contrário, ele teria que ouvir que preferiu, transgredindo as maiores leis, viver a qualquer custo, contrariando tudo em que acreditou durante toda a sua vida. (53d8-e6).

Tendo mostrado que Sócrates não conseguiria nenhum benefício para si com a fuga, particularmente no que diz respeito a continuar filosofando, as Leis argumentam ainda que ele ainda colocaria em perigo a vida de seus amigos que o ajudassem na fuga (53b1-3). Além disso, nem seus filhos seriam beneficiados, pois elas argumentam que seria melhor que eles permanecessem em Atenas, educados e sustentados por seus amigos, mesmo na hipótese do exílio, pois eles se tornariam cidadãos atenienses, não estrangeiros, passando a ser desprovidos de direitos políticos. Mas, se este era o caso, não faria diferença se ele vivesse ou morresse:

“Ou cuidarão deles se você partir para a Tessália, mas, se partir para o Hades, não? Se, ao menos, há realmente alguma 
utilidade para os que the dizem que são seus amigos, você certamente deve considerar que sim! ${ }^{46, "}(54 \mathrm{a} 8-\mathrm{b} 2)$

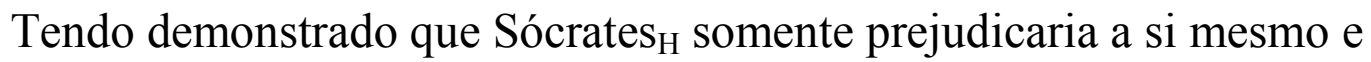
aos seus, se empreendesse a fuga, ele e Críton estão aptos agora a responderem por si sós a pergunta feita no trecho (XIII). Deste modo, a injustiça feita em (XIV) mostra-se injustificada pelos argumentos iniciais de Críton e, além disso, esses mesmos argumentos voltam-se contra ele. Portanto as Leis já podem falar em violação de (XI), mesmo sob a ótica de R2. Elas, então, resumem a sua argumentação em (54b9-d1):

“Agora, no entanto, se você partir, partirá, sendo injustiçado não por nós, as leis, mas pelos homens; mas, se sair tão vergonhosamente, tendo revidado uma injustiça com uma injustiça ou um mal com um mal ${ }^{47}$, tendo transgredido os seus acordos e o convencionado conosco ${ }^{48}$, e tendo feito mal a estes a quem menos deveria fazer - a si mesmo, aos amigos ${ }^{49}$, ao país e a nós - nós ficaremos irritadas com você enquanto viver, e lá, no outro mundo, as nossas irmãs, as leis no Hades, não o receberão gentilmente, sabendo que, dentro das suas possibilidades, você tentou destruir inclusive a nós. ${ }^{50,}$

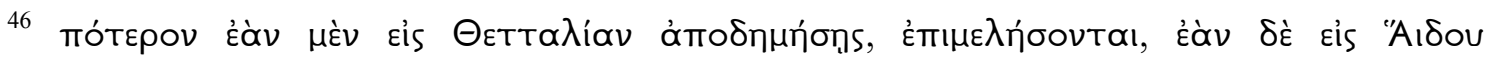

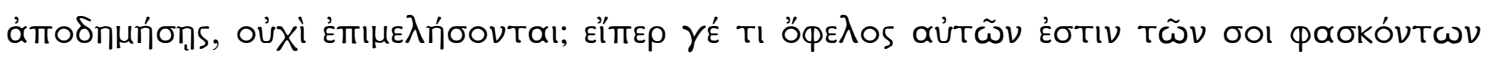

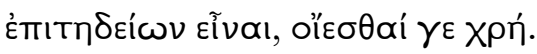

${ }^{47}$ violando (XI).

${ }^{48}$ violando (XII).

${ }^{49}$ Derrubando o argumento inicial de Críton.

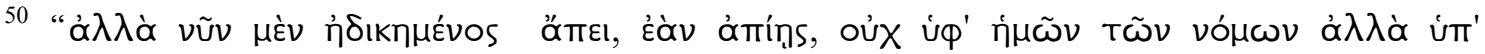

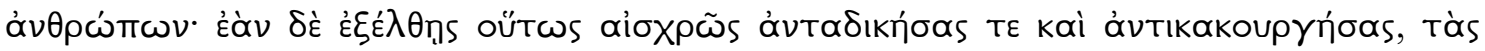

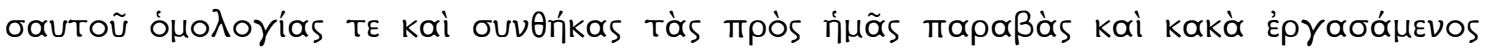

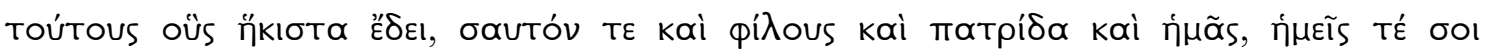


Note-se que, a partir do que foi dito acima, entre os malefícios de se cometer a injustiça da fuga está, ainda, o fato de Sócrates $_{\mathrm{H}}$, quando morrer, ter de enfrentar a fúria das Leis no Hades, o que modo tollente implica que, para que haja a possibilidade de ele ser bem recebido pelas Leis do Hades, necessariamente, ele deve deixar este mundo tendo vivido de modo justo.

Convidado a mostrar novos argumentos em prol da fuga, Sócrates dá-se por satisfeito:

“A isso, querido amigo Críton, esteja certo que julgo ouvir como aqueles tomados pelo entusiasmo coribântico julgam ouvir flautas, e em mim o som destes argumentos ressoa e torna impossível ouvir outros. ${ }^{51 \text { " }(54 \mathrm{~d} 3-6)}$

Críton, convidado a prosseguir, não consegue. Desta vez, a meu ver, por estar em completa aporia:

"Ora, Sócrates, não posso dizer mais nada. ${ }^{52 " ~(54 d 9) ~}$

Com mais nada a acrescentar, o diálogo termina com Sócrates afirmando:

"Por isso, Críton, ceda e façamos assim, já que assim o deus conduz. ${ }^{53 "}(54 \mathrm{e} 1-2)$

Portanto, é consistente que as Leis tenham argumentado contra a fuga tomando (XI) como sendo R2.

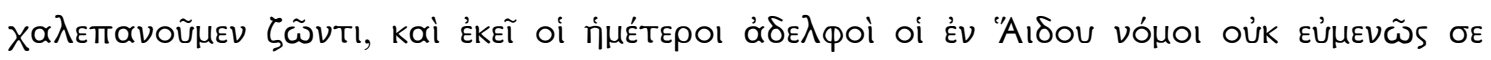

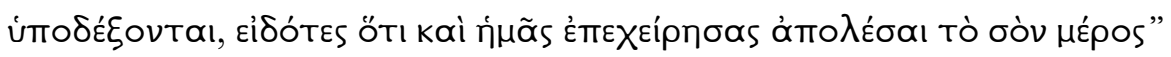

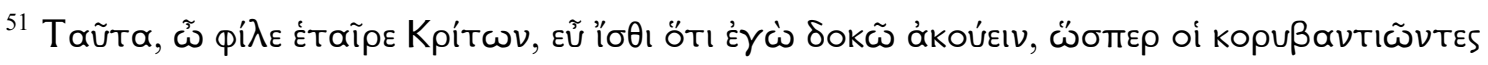

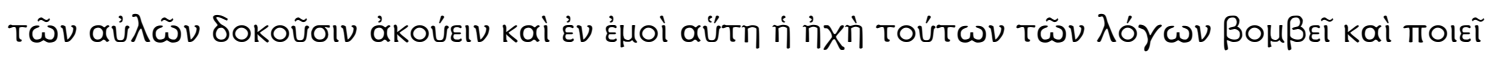

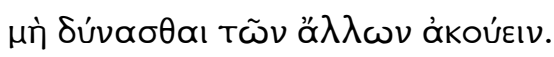

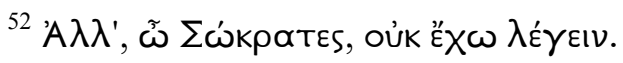

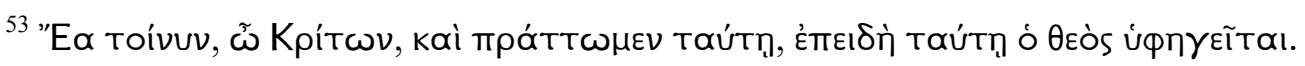


Stokes $^{54}$, no entanto, perguntou-se se não existiriam outras interpretações de (XI) que fossem, além de coerentes, mais "aderentes" à argumentação das Leis. Analisando mais detalhadamente o trecho (XVII), ele interpretou que este indiretamente não só autorizava, mas também justificava, que se revidasse o que se tivesse sofrido, desde que a justiça

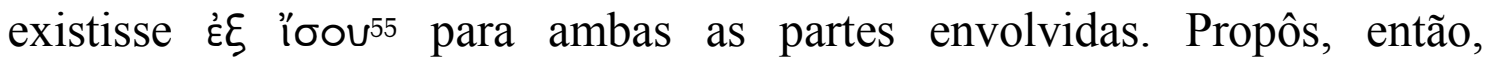
mantendo o estilo em que foram formulados R1 e R2 por Irwin, mais duas possibilidades para (XI).

O princípio R3 diz que

1. Se A cometeu uma injustiça x em B;

2. Se, caso A não tivesse cometido $\mathrm{x}$ em $\mathrm{B}$, o fato de $\mathrm{B}$ fazer y a A for considerado uma injustiça maior que ter sofrido x de A;

3. Então, B não deve fazer y a $\mathrm{A}$.

O princípio R4 diz que

1. Se A cometeu uma injustiça x em B;

2. Se, caso A não tivesse cometido x em $\mathrm{B}$, o fato de $\mathrm{B}$ fazer y a A for considerado uma injustiça maior que ter sofrido x de A;

4. Então, o fato de ter sofrido x não é uma razão suficiente para que $B$ faça y a $A$.

O princípio R3 implicaria a lex talionis, isto é, permitiria, por exemplo, no máximo, "um olho por olho", mas nunca "uma cabeça por um olho". R4, por sua vez, afirmaria que, retomando o exemplo acima, para que se tomasse a cabeça por um olho, seriam necessárias mais justificativas, além da perda do olho em si.

\footnotetext{
${ }^{54}$ STOKES, 105 ss.

55 "a partir de uma igualdade". Ver nota em 50e5.
} 
$\mathrm{Se}$ as Leis tivessem R3 em mente quando formularam (XVI)(XVIII), estes, como fizeram com R1, seriam suficientes, segundo Stokes, para tornar a fuga injustificável, pois, como a relação entre as Leis e os demais não está definida $\varepsilon^{\prime} \xi$ íoou, todo revide por parte destes seria mais injusto.

Contudo, se fosse, finalmente, R4 a interpretação das Leis, teríamos, segundo Stokes, uma situação exatamente idêntica à de R2, isto é, embora (XIV) não pudesse ser justificado somente por (XV), haveria os outros argumentos de Críton que poderiam justificá-la. Assim, como as mesmas contestações utilizadas contra tais argumentos, interpretando (XI) como R2, são válidas quando formuladas tendo R4 em mente, Stokes concluiu que R4, além de coerente, era mais aderente ao diálogo que R2.

A meu ver, a formulação de R3 e R4 apresenta um problema muito sério: de onde vem a ordenação a partir da qual todas as injustiças são comparadas? Essa pergunta faz sentido, pois o diálogo só menciona explicitamente duas categorias possíveis para que as ações sejam classificadas: justo e não-justo. Stokes admitiu simplesmente, para que pudesse apresentar R3 e R4 como interpretações plausíveis de (XI), que, se a justiça não estivesse definida $̇ \xi \zeta$ íoou para os membros de um grupo $\mathrm{A}$ e os de B (e se supuséssemos que A está em um patamar superior ao de B), então, se um membro de A cometesse uma injustiça $X$ contra um membro de $\mathrm{B}$, qualquer injustiça $\mathrm{Y}$ que um membro de $\mathrm{B}$ cometesse contra um outro de A seria maior que X. Contudo os trechos (XVII) e (XVIII), nos quais ele se baseou, não são suficientes, penso, para dar suporte a tal hierarquia. Os dois trechos permitem que se conclua, seguindo ainda o exemplo acima, que não é justo que $\mathrm{B}$ cometa uma injustiça $\mathrm{Y}$ a um 
membro de $\mathrm{A}$, caso tenha sofrido da parte deste uma injustiça $\mathrm{X}$, porém não se pode afirmar que a injustiça $\mathrm{Y}$ é maior que a $\mathrm{X}$ a partir disso.

Além disso, mesmo que se aceitasse a ordenação arbitrada por Stokes entre as injustiças cometidas pelos membros de A nos membros de B e vice-versa, faltaria explicar como seriam comparadas as demais injustiças, como, por exemplo, as cometidas pelos membros de um grupo nos membros do próprio grupo, pois, para que R3 implique a lex talionis ou para que R4 vá além dela, a ordenação entre as injustiças deve ser total, isto é, qualquer injustiça deve ser comparável à outra.

Seria razoável pressupor que exista, mesmo implicitamente, uma hierarquia total entre as injustiças neste diálogo? Seria mais defensável, a meu ver, supor que o Sócrates que refutou Céfalo no exemplo que citamos na seção anteriormente, possuísse, implicitamente, uma tal hierarquia, mas isto não está claro, como vimos, no Críton. Deste modo, diante da falta de uma ordenação entre as injustiças melhor definida, explicitada e fundamentada da parte de Stokes, e da implausibilidade de se supor uma no diálogo, penso, não se pode apresentar R4 como uma alternativa a R2.

A idéia de Stokes de propor R3 e R4, a meu ver, pode ter sido motivada pelo fato de ele ter entendido que a cooperação e complementaridade que ele supõe existir entre a argumentação de Sócrates, na primeira parte do diálogo, e a das Leis, na segunda, ocorria do seguinte modo: Sócrates proibia de todo modo que se cometesse uma injustiça, sem mostrar que a fuga era injusta, enquanto que as Leis provavam que a fuga contaria como uma injustiça, pois seria uma retaliação injusta, qualquer que

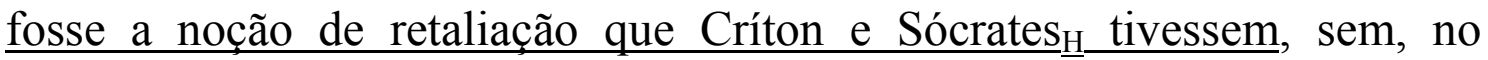
entanto, proibir que se cometesse uma injustiça ${ }^{56}$. Quanto menores fossem,

\footnotetext{
${ }^{56}$ STOKES, pp 117.
} 
portanto, as restrições à retaliação - o que ocorre introduzindo-se os princípios R3 e R4 - mais poderoso seria, no seu entender, o argumento das Leis.

No entanto, pode-se entender, a meu ver, que esta complementaridade e cooperação entre a argumentação de ambos ocorre de maneira diversa: Críton argumentou que Sócrates prejudicaria, permanecendo na prisão, a si mesmo, seus amigos e seus filhos, ou seja, aqueles a quem ele, na sua visão, menos deveria prejudicar. Sócrates, admitindo discutir a fuga, estabeleceu que ele a aceitaria, somente se esta se mostrasse justa. Estabelece, então, que não se deveria revidar uma injustiça de modo injusto nem quebrar acordos justos. Diante destas premissas, perguntou, finalmente, a Críton se a fuga não causaria um mal àqueles a quem menos deveria causar. Diante do espanto e da incompreensão de Críton face a esta pergunta, as Leis de Atenas entraram em cena para mostrar que a fuga seria uma injustiça contra elas e a cidade, e contaria como um rompimento de um acordo justo. Em seguida, mostraram que esta injustiça seria tão grande que prejudicaria Sócrates e seus amigos, além de não beneficiar os seus filhos. Tal injustiça, portanto, seria também uma retaliação injusta contra as Leis e a cidade, sob a ótica de R2. Terminada a fala das Leis, a incompreensão de Críton desaparece mas talvez não o seu espanto: ele percebe que seu argumento tinha sido não só derrubado mas direcionado contra ele mesmo. Finalmente, por estar em aporia, Críton desiste de argumentar. Resumindo, Sócrates e as Leis agem de modo complementar e cooperativo para deixar Críton em aporia. Por este ponto de vista, enfraquecer R2, como fez Stokes, não alteraria em nada a argumentação das Leis. 


\section{Conclusão}

Entendendo, finalmente, que R2, entre as interpretações de (XI) que nos dispusemos a analisar, é a mais consistente com o discurso das Leis, basta, para que terminemos esta análise, que comentemos a possibilidade de que Sócrates, mesmo assim, tenha tido em mente N1 ou N2 quando formulou (IX), como propôs Vlastos, ou que interpretasse (XI) como R1, uma possibilidade aventada por Irwin e Stokes. Em qualquer um desses casos, diante do que foi exposto, devemos concluir que a linha argumentativa Sócrates estava, necessariamente, dissociada daquela seguida pelas Leis, isto é, que cada uma das partes tinha o seu próprio entendimento acerca das restrições à retaliação. Porém, com essa dissociação, a hipótese de que Sócrates interpretasse (XI) como N1, N2 ou $\mathrm{R} 1$, embora perfeitamente possível, torna-se mais fraca do que a de que fosse algo parecido com R2 o que ele tenha tido em mente, já que nem N1 nem N2 nem R1 podem ser sustentados com argumentos advindos do próprio Críton. 


\section{Quadro sinótico dos trechos referenciados no capítulo}

I. "De modo algum, devemos cometer uma injustiça deliberadamente ou, de algum modo, devemos, mas, de outro, não?" (Sócrates)

II. "De modo algum cometer uma injustiça, porque é injusto, é belo e bom, como muitas vezes nós também anteriormente concordamos?" (Sócrates)

III. "Ou todos os princípios com as quais concordávamos antes foram descartados nestes poucos dias e, anteriormente, Críton, como agora se evidencia, nós mesmos, homens de idade, não notamos que, embora conversássemos seriamente um com o outro, em nada diferíamos de crianças?Ou acima de tudo é assim como então se costumava dizer: se a maioria afirmar ou não, ou melhor, se tivermos ainda que sofrer algo mais difícil que isso ou mais fácil, não obstante, cometer uma injustiça, porque é injusto, vem a ser ruim e vergonhoso para quem a comete, de qualquer maneira."(Sócrates)

IV. "De modo algum se deve, então, cometer uma injustiça". (Sócrates)

V. Nem, portanto, revidar com uma injustiça se sofrer uma injustiça. (Sócrates)

VI. "Como crê a maioria (a respeito de (V))." (Sócrates).

VII. “Aparentemente não".(Críton - comentando (V)).

VIII. “Deve-se, Críton, fazer mal a alguém ou não?” (Sócrates).

IX. "É justo revidar com um mal, se sofrer um mal, como afirma a maioria, ou injusto?" (Sócrates).

X. "Pois, presumo, fazer mal aos homens em nada difere de cometer uma injustiça”. (Sócrates) 
XI. "Não se deve, portanto, nem revidar com uma injustiça nem fazer mal a nenhum dos homens, nem mesmo se vier a sofrer qualquer coisa da parte deles". (Sócrates)

XII. "Sempre que alguém estiver de acordo com outrem em relação a certas coisas, sendo elas justas, ele deve cumprir o acordo." (Sócrates)

XIII. "Nós, indo embora daqui sem ter persuadido a cidade, nós fazemos mal a alguns, mais precisamente, aos que menos devemos fazer, ou não?" (Sócrates)

XIV. "Não é verdade que, com esse ato que você empreende, você planeja destruir, tanto quanto lhe cabe, a nós, as leis, e a cidade como um todo?" (Leis)

$\mathrm{XV}$. "Sim, tentaremos isso, porque A cidade foi injusta conosco e não aplicou corretamente a justiça" (Sócrates $\mathrm{H}_{\mathrm{H}}$ Críton).

XVI. "Depois que nasceu e foi nutrido e educado, você poderia dizer, em primeiro lugar, que, a seu ver, não era nosso filho ou escravo, nem você nem seus ancestrais?” (Leis)

XVII. "Você considera que o justo exista a partir de uma igualdade para você e para nós, mais precisamente, aquilo que tentarmos fazer-lhe você considera que seja justo também para você fazer de volta em represália?” (Leis)

XVIII. "Ou, por um lado, como era evidente, em relação ao seu pai e ao seu senhor, se por acaso teve um, o justo não existia a partir de uma igualdade, de modo que você também fizesse de volta em represália precisamente aquilo que sofresse, ou seja, não era justo que, se falavam mal de você, você respondesse nem que, se fosse atacado, contraatacasse nem que fizesse muitas coisas semelhantes a estas; mas, por outro lado, em relação à pátria e às leis, como se envidencia, será 
permitido a você fazer tudo isso, de modo que, se nós tentarmos destruílo, considerando que isso seja justo, você também, tanto quanto seja capaz, tentará destruir-nos, às leis e à pátria, e dirá que, fazendo isso, pratica ações justas, você que verdadeiramente cuida da virtude" (Leis). 
Quadro sinótico dos princípios de não-retaliação propostos por Irwin e/ou Stokes

$\mathrm{R} 1$

1. Se A cometeu uma injustiça $\mathrm{Y}$ em $\mathrm{B}$, ;

2. Se B fizer $X$ a A e $X$ for considerado uma injustiça, caso $A$ não tenha feito $\mathrm{Y}$ a B;

3. Então, B não deve fazer X a A. (Irwin/Stokes)

R2

1. Se A cometeu uma injustiça $\mathrm{Y}$ em B;

2. Se B fizer $X$ a $A$ e $X$ for considerado uma injustiça, caso $A$ não tenha feito $\mathrm{Y}$ a $\mathrm{B}$;

3. Então, o fato de ter sofrido $Y$ não é uma razão suficiente para que B faça X a A. (Irwin/Stokes)

R3

1. Se A cometeu uma injustiça x em B;

2. Se, caso A não tivesse cometido x em B, o fato de B fazer y a A for considerado uma injustiça maior que ter sofrido $\mathrm{x}$ de $\mathrm{A}$;

3. Então, B não deve fazer y a A. (Stokes)

$\mathrm{R} 4$

1. Se A cometeu uma injustiça x em B;

2. Se, caso A não tivesse cometido $\mathrm{x}$ em $\mathrm{B}$, o fato de $\mathrm{B}$ fazer y a A for considerado uma injustiça maior que ter sofrido $\mathrm{x}$ de $\mathrm{A}$;

3. Então, o fato de ter sofrido x não é uma razão suficiente para que B faça y a A. (Stokes) 
Quadro sinótico dos princípios de não-retaliação propostos por Vlastos

N1 "Não se deve revidar com um dano físico ou com uma injustiça um mal sofrido." (Vlastos).

N2 "Não se deve revidar com um dano físico moralmente injustificado ou com uma injustiça um mal sofrido." (Vlastos) 


\section{Tradução do Críton}

KPITSN

\section{Criton}

So. (43a) Por que você chegou a esta hora, Críton? Não é cedo ainda ${ }^{1}$ ?

Cr. De fato, é muito cedo ${ }^{2}$.

So. Que hora mais precisamente ${ }^{3}$ ?

Cr. Quase alvorada ${ }^{4}$.

So. Eu me admiro ${ }^{5}$ como o guarda da prisão ${ }^{6}$ tenha consentido em atendêlo.

Cr. Ele já está acostumado comigo, Sócrates, porque venho aqui freqüentemente $\mathrm{e}^{7}$, além disso, recebeu de mim um agrado.

So. Você chegou agora há pouco ou já faz algum tempo?

Cr. Há um tempo razoável.

So. (43b) Nesse caso ${ }^{8}$, como você não me acordou imediatamente ao invés $\mathrm{de}^{9}$ ficar sentado em silêncio?

Cr. Não, por Zeus, Sócrates! Nem eu mesmo gostaria de estar com tanta insônia e dor ${ }^{10}$. Mas também há algum tempo estou admirado com você, observando como você está dormindo bem ${ }^{11}$; e propositadamente deixei de acordá-lo $^{12}$ para que você passasse o tempo do modo mais agradável possível. Muitas vezes, mesmo anteriormente, considerei-o feliz pelo seu modo de agir durante toda a sua vida, mas muito mais agora, no infortúnio presente, porque fácil e calmamente você o suporta ${ }^{13}$.

So. Com certeza, Críton, pois ${ }^{14}$ seria destoante ${ }^{15}$ indignar-me na minha idade porque devo morrer ${ }^{16}$ agora.

Cr. (43c) Também outros da mesma idade que a sua, Sócrates, são submetidos a tais infortúnios, mas a idade em nada os $\operatorname{livra}^{17}$ de se indignarem com a sorte presente. 
So. É verdade. Mas ${ }^{18}$ você chegou tão cedo por quê?

Cr. Chego, Sócrates, trazendo ${ }^{19}$ uma notícia triste. Não para você, como aparenta $^{20}$, mas triste e penosa para mim e para todos os seus amigos, a qual, como eu julgo ${ }^{21}$, poucos suportariam tão penosamente quanto $\mathrm{eu}^{22}$.

So. Qual notícia ${ }^{23}$ ? Já chegou de Delos ${ }^{24}$ o barco (43d) após cuja chegada ${ }^{25}$ devo morrer ${ }^{26}$ ?

Cr. Bem, de fato não ${ }^{27}$ chegou, mas, na minha opinião ${ }^{28}$, chegará hoje a partir do que informaram alguns que vieram de Súnio $^{29}$ e abandonaram-no lá. É claro, portanto, a partir destes informantes ${ }^{30}$, que chegará hoje, e que amanhã será realmente forçoso, Sócrates, que a sua vida chegue ao fim ${ }^{31}$.

So. Tomara, Críton, que seja para uma sorte melhor ${ }^{32}$ ! Se dessa maneira é agradável aos deuses, que assim seja! Não creio, no entanto, que o barco chegará hoje.

Cr. (44a) De onde você conclui isso?

So. Eu lhe direi. Devo morrer um dia depois de o barco chegar, não é isso $^{33}$ ?

Cr. Sem dúvida! ${ }^{34}$ ao menos, afirmam os que tem autoridade sobre isso ${ }^{35}$.

So. Por isso ${ }^{36}$, penso que o barco não chegará no dia que está por vir, mas no seguinte. Concluo ${ }^{37}$ isso de um sonho que acabei de ter um pouco antes, durante essa noite. E é possível que você não me tenha acordado em um momento oportuno.

Cr. Mas o sonho era ${ }^{38}$ o quê?

So. Parecia ${ }^{39}$ que uma mulher bela e atraente (44b), vestida de branco, depois de se aproximar de mim, chamou-me e disse: "Sócrates, no terceiro dia poderás alcançar a fértil $\mathrm{Ftia}^{40} 41$ ".

Cr. Que sonho estranho, Sócrates ${ }^{42}$ !

So. Pelo contrário ${ }^{43}$, Críton, ele é claro ${ }^{44}$. Eu, ao menos ${ }^{45}$, julgo assim. 
Cr. Bem claro ${ }^{46}$, como aparenta. $\mathrm{Mas}^{47}$, divino ${ }^{48}$ Sócrates, mesmo agora ${ }^{49}$ deixe-se persuadir ${ }^{50}$ por mim e salve-se. Porque, se você morrer, para mim não há um único infortúnio ${ }^{51}$ : além de ser privado de um amigo tal qual com certeza nunca mais encontrarei ${ }^{52} \mathrm{um}$, muitos ainda que não conheçam bem $^{53}$ nem a mim nem a você, julgarão que fui negligente, porque, alegariam $^{54}$, (44c) eu seria capaz de salvá-lo se quisesse gastar dinheiro ${ }^{55}$. Ora ${ }^{56}$ que reputação ${ }^{57}$ seria mais vergonhosa que esta ${ }^{58}$, parecer estimar mais o dinheiro que os amigos? Pois a maioria não acreditará ${ }^{59}$ que foi você mesmo quem se recusou ${ }^{60}$ a fugir daqui, ainda que nós nos esforçássemos por isso ${ }^{61}$.

So. Mas $^{62}$ por que, meu caro Críton, nos preocupamos tanto com o juízo da maioria ${ }^{63}$ ? Pois os mais capazes $^{64}$, que são mais dignos de atenção, considerarão que as coisas foram feitas assim como vierem a ser feitas ${ }^{65}$.

Cr. (44d) $\mathrm{Mas}^{66}$ você certamente vê ${ }^{67}$ que também é necessário, Sócrates, preocupar-se com o juízo da maioria ${ }^{68}$. Os eventos atuais evidenciam que a maioria é capaz de realizar não os menores mas quase que os maiores males se, entre eles, alguém for caluniado.

So. Quem dera ${ }^{69}$, Críton, que a maioria fosse capaz de realizar os maiores males para que também fosse capaz dos maiores bens ${ }^{70}$. Isso seria bom. Mas, de fato ${ }^{71}$, a maioria não é capaz de realizar nenhuma das duas coisas, pois ela não é apta a tornar alguém ${ }^{72}$ nem sábio nem tolo, mas faz aquilo que lhe ocorrer.

Cr. (44e) Que assim seja ${ }^{73}$ ! Mas responda-me isto, Sócrates: ora $^{74}$, você não está preocupado comigo e com os demais amigos, receoso de que ${ }^{75}$, se fugir daqui, os sicofantas ${ }^{76}$ nos causem problemas, alegando ${ }^{77}$ que o subtraímos daqui? De que sejamos obrigados a perder toda a nossa propriedade, uma grande soma em dinheiro, ou inclusive ${ }^{78}$ a sofrer alguma 
outra coisa além ${ }^{79}$ ? Porque ${ }^{80}$, se você (45a) teme algo semelhante, esqueça$\mathrm{o}^{81}$. Pois, presumo ${ }^{82}$, é justo que corramos este risco, salvando-o, e um outro ainda maior que este se ainda for preciso. $\operatorname{Vamos}^{83}$, deixe-se persuadir por mim $^{84}$ e não faça de outro modo.

So. Estou preocupado, Críton, com isso e com muitas outras coisas.

Cr. Então ${ }^{85}$, não ${ }^{86}$ as tema, pois, de fato, ${ }^{87}$ nem é muito o dinheiro que querem alguns homens que estão dispostos a salvá-lo e a tirá-lo daqui ${ }^{88}$. Ademais, estes sicofantas ${ }^{89}$, você não vê como eles são baratos e como não seria preciso muito dinheiro (45b) para eles? E o meu dinheiro está à sua disposição, o que, a meu ver, é suficiente. Além do mais ${ }^{90}$, mesmo se você considerar, por se preocupar comigo, que não deve gastar meu dinheiro, esses estrangeiros aqui ${ }^{11}$ estão prontos para fazê-lo. Um deles inclusive, Símias de Tebas, conseguiu, para isso mesmo, dinheiro suficiente; e também Cebes ${ }^{92}$ está pronto e muitos outros. De modo que, como afirmo, nem hesite ${ }^{93}$ em se salvar temendo essas coisas nem deixe que se torne preocupante para você aquilo que você dizia no seu julgamento ${ }^{94}$ : que você não saberia, se partisse para o exílio, o que fazer ${ }^{95}$ consigo mesmo $(45 \mathrm{c})$. Porque em muitos lugares, ou melhor ${ }^{96}$, em qualquer lugar onde chegar, você será bem tratado, mas se quiser ir à Tessália ${ }^{97}$, tenho amigos lá que o estimarão muito e que lhe oferecerão segurança, de modo que ninguém da região da Tessália lhe fará mal.

Além do mais, Sócrates, eu julgo que não seja justo que você empreenda tal coisa, que traia a si mesmo, sendo possível ser salvo. Você instiga que ocorram aos seus amigos e familiares ${ }^{98}$ exatamente o que também os seus inimigos, ao querer destruí-lo, instigariam e instigaram. Além disso, eu julgo que você (45d) trai também os seus filhos, porque ${ }^{99}$, embora seja possível nutri-los e educá-los, você partirá ${ }^{100}$, tendo-os deixado 
sós. E, no que depende de vocêt ${ }^{101}$, eles lograrão ${ }^{102}$ aquilo que obtiverem fortuitamente ${ }^{103}$, e obterão, como é provável, aquilo que precisamente costuma ocorrer entre os órfãos na orfandade. Pois ou não se deve fazer filhos ou deve-se enfrentar as dificuldades com eles, nutrindo-os e educando-os. Mas julgo que você escolhe o mais fácil. Você, ao menos, que vem afirmando incisivamente durante toda a vida que cuidou da virtude $^{104}$ deve, no entanto, escolher exatamente o que um homem nobre e corajoso escolheria. Porque ${ }^{105} \mathrm{eu}$, ao menos, me envergonho ${ }^{106}$ por você e por nós, seus amigos, e temo que julguem que todo o seu processo ${ }^{107}$ (45e) tenha sido conduzido com alguma covardia de nossa parte - primeiramente, como se deu a entrada do caso no tribunal, uma vez que era possível que não tivesse entrado ${ }^{108}$; em seguida, como ocorreu o desenvolvimento do caso especificamente ${ }^{109} \mathrm{e}$, no fim, essa cena aqui ${ }^{110}$, como se fosse a parte ridícula do ato ${ }^{111}$ : que julguem ${ }^{112}$ que, por algum vício ou covardia de nossa parte, esta oportunidade tenha-nos escapado (46a) porque ${ }^{113}$ não $o$ salvamos nem você a si mesmo, embora isso fosse possível e factível ${ }^{114}$ se fôssemos de alguma ${ }^{115}$ utilidade. Portanto, Sócrates, cuide ${ }^{116}$ para que isso além de ruim não seja também vergonhoso ${ }^{117}$ para você e para nós. $\operatorname{Vamos}^{118}$, decida-se - ou melhor ${ }^{119}$, não é mais hora de decidir, mas de estar decidido. Só há uma decisão, pois na noite que se aproxima ${ }^{120}$ isso já deverá estar feito. Se ainda esperarmos, a fuga será impraticável e não será mais possível empreendê-la ${ }^{121}$. Vamos ${ }^{122}$, Sócrates, de qualquer maneira, deixe-se persuadir por $\operatorname{mim}^{123}$ e de forma alguma faça de outro modo.

So. (46b) Caro Críton, o seu ímpeto seria digno de muita consideração, se estivesse acompanhado de alguma correção ${ }^{124}{ }^{125}$, caso contrário, quanto maior ele for, mais difícil de lidar. Temos, então, de examinar ${ }^{126}$ se 
devemos fazer isso ou não, porque eu não agora pela primeira vez mas, de fato, sempre ${ }^{127}$ tenho sido do tipo tal que não me deixo persuadir por nada que esteja sob meu comando ${ }^{128}$ a não ser pelo raciocínio que se mostrar melhor para mim quando raciocino ${ }^{129}$. Assim ${ }^{130}$, os argumentos que costumava proferir anteriormente, não posso descartá-los agora porque este infortúnio ocorreu comigo; pelo contrário ${ }^{131}$, eles se mostram para mim quase idênticos aos anteriores, e estimo e honro os mesmos que (46c) antes $^{132}$. Então ${ }^{133}$, se não pudermos proferir, na presente ocasião, um $\operatorname{argumento}^{134}$ melhor do que estes, saiba bem que, definitivamente, não ${ }^{135}$ cederei a você nem se o poder da maioria nos "mormorizar"136, como se fôssemos crianças, mais do que agora, infligindo-nos correntes, mortes e confisco de dinheiro ${ }^{137}$. Como, então, poderíamos examinar ${ }^{138}$ isso na melhor medida possível? E se retomássemos primeiramente este $\operatorname{argumento}^{139}$ que você afirma acerca dos juízos ${ }^{140}$ ? Costumava-se ou não dizer corretamente ${ }^{141}$, em cada ocasião (46d), que, quanto aos juízos ${ }^{142}$, deve-se prestar atenção a alguns, mas a outros não ${ }^{143}$ ? Ou, antes que eu devesse morrer ${ }^{144}$, falava-se corretamente ${ }^{145}$, mas agora, depois de tudo que ocorreu $^{146}$, tornou-se evidente que se argumentava ${ }^{147}$ somente por argumentar, e que tudo era realmente uma brincadeira e uma tolice? $\mathrm{Eu}$, ao menos, desejo examinar conjuntamente com você ${ }^{148}$, Críton, se, porque estou nessa situação, este argumento, para mim, se mostra algo diferente do anterior ${ }^{149}$ ou idêntico, e se nós seremos persuadidos por ele ${ }^{150}$ ou se deixaremos como está ${ }^{151}$. Os que pensam dizer algo de valor ${ }^{152}$ costumavam dizer em cada ocasião, penso eu, mais ou menos assim ${ }^{153}$ como eu precisamente dizia agora, que alguns dos juízos ${ }^{154}$ que (46e) os homens produzem deviam ser muito estimados, mas outros não. Diante dos deuses, Críton, você não julga que isso é dito corretamente ${ }^{155}$ ? Porque, 
humanamente falando ${ }^{156}$, está fora de cogitação que você (47a) morra amanhã ${ }^{157}$, e a presente circunstância não o poderia abalar. Examine, então $^{158}$ : você não julga que é dito satisfatoriamente ${ }^{159}$ que não se deve estimar todos os juízos ${ }^{160}$ dos homens, mas alguns sim, outros não; e nem de todos eles: mas de uns sim, de outros não? Que você me diz? Isso aí não é dito corretamente?

Cr. $\dot{E}^{161}$.

So. Então os bons deve-se estimar, mas os ruins, desprezar?

Cr. Sim.

So. Mas os bons não são os dos sábios e os ruins, os dos tolos?

Cr. Como não ${ }^{162}$ ?

So Diga, então ${ }^{163}$ : como se costumava argumentar a respeito de tais coisas? Um homem que pratica ginástica (47b) e empenha-se nisso ${ }^{164}$, presta atenção ao elogio, à censura ou ao juízo ${ }^{165}$ de qualquer homem ou de somente um único, o que, por acaso, for médico ou treinador?

Cr. Deste somente.

So. Então deve-se temer as censuras e acolher os elogios deste único homem, mas não os da maioria.

Cr. Evidentemente ${ }^{166}$.

So. Portanto ele deve agir, exercitar-se, além de ${ }^{167}$ comer e beber, da maneira como julgar este único homem - que é o dirigente e quem conhece - mais que da maneira como julgarem todos os outros.

Cr. É isso mesmo ${ }^{168}$.

So. (47c) Bem, desobedecendo a esse único homem e desrespeitando o juízo ${ }^{169}$ e os elogios dele, mas estimando os da maioria, isto é ${ }^{170}$, os dos que não conhecem absolutamente nada ${ }^{171}$, ele não sofrerá algum mal?

Cr. Certamente sofrerá ${ }^{172}$. 
So. Qual é este mal? Para onde ele tende? Em qual das partes daquele que desobedece ele age ${ }^{173}$ ?

Cr. É claro que é no corpo, pois ele o destrói.

So. Você fala bem ${ }^{174}$. Ora, as demais coisas não são assim, para que não percorramos todas? Particularmente, as que são acerca das coisas justas e injustas, das vergonhosas e nobres, das boas e ruins, destas acerca das quais a nossa deliberação trata? Assim, nós devemos nos deixar persuadir pelo juízo $^{175}$ da maioria e temê-lo (47d) ou pelo juízo daquele único homem, se é alguém que conhece, porque é diante dele que devemos sentir vergonha e temor mais do que diante de todos os demais? ${ }^{176}{ }^{177} \mathrm{E}^{178}$, se não o seguirmos, destruiremos e arruinaremos aquilo que, como dizíamos, tornase melhor com o justo, mas é destruído com o injusto ${ }^{179}$. Ou não é nada disso?

Cr. Eu penso que $\operatorname{sim}^{180}$, Sócrates.

So. Diga, então ${ }^{181}$ : se destruímos o que se torna melhor pelo saudável, mas que é corrompido pela doença, deixando-nos persuadir pelo juízo ${ }^{182}$ dos que não conhecem ${ }^{183}$, vale a pena para nós viver, uma vez que ele está corrompido? Isso, presumo ${ }^{184}$ (47e), é o corpo, não é ?

Cr. Sim.

So. Vale, então, a pena para nós viver ${ }^{185}$ com o corpo arruinado e corrompido?

Cr. De forma alguma.

So. Bem, vale, então ${ }^{186}$, a pena para nós viver com isto corrompido, com o que o injusto arruína, mas o justo beneficia? Ou consideramos que isso - o que quer que seja (48a) das nossas partes, acerca do qual é tanto a injustiça quanto a justiça - é de menor importância que o corpo?

Cr. De forma alguma. 
So. Mas ${ }^{187}$ mais valioso?

Cr. Muito mais.

So. Então, excelente homem, não nos deve preocupar tanto assim o que a maioria dirá de nós ${ }^{188}$, mas o que ${ }^{189}$ dirão quem conhece acerca das coisas que são justas e injustas, ou seja, este único homem, e a própria verdade. Conseqüentemente ${ }^{190}$, em primeiro lugar, você não introduz corretamente a discussão deste modo, afirmando que devemos nos preocupar com o juízo ${ }^{191}$ da maioria acerca das coisas que são justas, belas e nobres e das contrárias. "Mas, no entanto"192", alguém poderia muito bem afirmar, "é possível que a maioria nos mate".

Cr. (48b) Isso também é evidente, porque alguém afirmaria isso, Sócrates ${ }^{193}$.

So. Você diz a verdade. Mas ${ }^{194}$, homem admirável, este argumento que acabamos de concluir eu julgo que ainda é semelhante ao anterior ${ }^{195} 196$. Examine ${ }^{197}$ novamente se ainda este aqui permanece ou não: que não se deve dar máxima importância ao viver, mas ao viver bem.

Cr. Certamente permanece ${ }^{198}$.

So. E permanece ou não que "bem", "belamente" e "justamente" 199 são idênticos ${ }^{200}$ ?

Cr. Permanece.

So. Deve-se, portanto, examinar ${ }^{201}$ isso a partir daquilo com que concordamos: se é justo ${ }^{202}$ ou não que eu tente sair daqui sem a permissão dos atenienses. E, se isso se mostrar (48c) justo, tentemos; caso contrário, desistamos. Quanto às considerações que você vem proferindo acerca do gasto de dinheiro, da reputação ${ }^{203}$ e da criação dos filhos ${ }^{204}$, suspeito, Críton, que ${ }^{205}$ estas $^{206}$ sejam, verdadeiramente, questões próprias para a consideração dos que facilmente condenam pessoas à morte e que, além 
$\operatorname{disso}^{207}$, as trariam ${ }^{208}$ de volta à vida se pudessem, sem nenhuma reflexão, isto é, próprias para a consideração destes, os da maioria ${ }^{209}$. Quanto a nós ${ }^{210}$, no entanto, já que o raciocínio assim escolhe ${ }^{211}$, suspeito que não nos seja necessário examinar ${ }^{212}$ nenhuma outra questão ${ }^{213}$ que não seja precisamente aquela de que falávamos agora mesmo: se nós agiremos de modo justo, pagando a esses que me levarão para fora daqui com dinheiro e gratificações - por nós entendendo ${ }^{214}$ os que levam (48d) e quem se deixa levar ${ }^{215}$ - ou, se, realmente, fazendo todas essas coisas, cometeremos uma injustiça; e, se ficar evidente que agimos de modo injusto ${ }^{216}$, temo que ${ }^{217}$, diante de cometer uma injustiça, não devamos levar em conta nem se devemos morrer, ficando aqui e permanecendo em silêncio, nem se devemos sofrer qualquer outra coisa.

Cr. Eu julgo que você fala bem, Sócrates, mas veja o que devemos fazer ${ }^{218}$. So. Examinemos ${ }^{219}$, meu caro, conjuntamente, e, se de algum modo puder contestar-me enquanto eu falar, conteste, e eu me deixarei persuadir por você $\hat{e}^{220}$, senão pare já, (48e) caro, de dizer repetidamente a mesma coisa, que eu devo ir embora daqui sem o consentimento dos atenienses ${ }^{221}$. Porque eu, ao menos, acho importante agir, quanto a isso, persuadindo-o ${ }^{222}$ antes, mas não sem o seu consentimento ${ }^{223}$. Assim, observe ${ }^{224}$ o princípio da investigação ${ }^{225}$, se este lhe for dito com senso $^{226}$, e tente responder a questão (49a) como você considerar melhor.

Cr. Certamente tentarei ${ }^{227}$.

So. Afirmamos ${ }^{228}$ que, de modo algum, devemos cometer uma injustiça ${ }^{229}$ deliberadamente ${ }^{230}$ ou que, de algum modo, devemos, mas, de outro, não? Ou de modo algum ${ }^{231}$ cometer uma injustiça, porque é injusto ${ }^{232}$, é belo e bom, como muitas vezes nós também anteriormente concordamos? Ou todos aqueles princípios com as quais concordávamos antes foram 
descartados nestes poucos dias, e, anteriormente, Críton, como agora se evidencia $^{233}$, nós mesmos (49b), homens de idade, não notamos que, embora conversássemos seriamente um com o outro, em nada diferíamos de crianças? Ou acima de tudo é assim como então se costumava dizer: se a maioria afirmar ou não, ou melhor ${ }^{234}$, se tivermos ainda que sofrer algo mais difícil que isso ou mais fácil, não obstante ${ }^{235}$, cometer uma injustiça, porque é injusto $^{236}$, vem a ser ruim e vergonhoso para quem a comete, de qualquer maneira? Afirmamos isso ou não?

Cr. Afirmamos.

So. De modo algum se deve, então ${ }^{237}$, cometer uma injustiça ${ }^{238}$.

Cr. Certamente não ${ }^{239}$.

So. Nem, portanto ${ }^{240}$, revidar com uma injustiça se sofrer uma injustiça, como crê a maioria, já que, obviamente ${ }^{241}$, de modo algum se deve cometer uma injustiça.

Cr. (49c) Aparentemente não ${ }^{242}$.

So. E quanto a isso aqui ${ }^{243}$ : deve-se, Críton, fazer mal a alguém ou não?

Cr. Certamente não se deve ${ }^{244}$, Sócrates.

So. E quanto a isso ${ }^{245}$ : é justo revidar com um mal, se sofrer um $\mathrm{mal}^{246}$, como afirma a maioria, ou injusto?

Cr. De forma alguma.

So. Pois, presumo, fazer mal aos homens não difere em nada de cometer uma injustiça.

Cr. Você diz a verdade.

So. Não se deve, portanto ${ }^{247}$, nem revidar com uma injustiça nem fazer mal a nenhum dos homens, nem mesmo se vier a sofrer qualquer coisa da parte deles. Cuide também, (49d) Críton, para que, aceitando estes princípios, você não concorde com uma crença ${ }^{248}$ contrária à sua, pois eu sei que 
poucos a estes consideram ou considerarão. $\mathrm{Na}$ verdade $^{249}$, eles, os que os consideram e os que não, não têm uma base comum para a deliberação ${ }^{250}$, $\mathrm{e}^{251}$, necessariamente, devem, observando as resoluções uns dos outros, desprezar uns aos outros. Examine ${ }^{252}$, então ${ }^{253}$, muito bem se você compartilha do princípio ${ }^{254}$ também e julga, como eu, que é assim, e comecemos a deliberar a partir deste ponto ${ }^{255}$, a saber, que nunca é correto nem cometer uma injustiça nem revidar com uma injustiça nem, tendo sofrido um mal, defender-se, revidando com um $\mathrm{mal}^{256}$. Ou se você recua e não compartilha do princípio? Porque (49e) eu julguei que era assim antes e ainda agora julgo, mas se você tem julgado que é de algum outro modo, fale e explique-se. Se, porém, você permanece com as crenças anteriores, ouça o meu próximo ponto ${ }^{257}$.

Cr. Certamente ${ }^{258}$ não só permaneço mas julgo, como você, que é assim. Vamos $^{259}$, diga.

So. Bem, da minha parte, digo ${ }^{260}$ o que vem a seguir, ou melhor ${ }^{261}$, pergunto: sempre que alguém estiver de acordo com outrem ${ }^{262}$ em relação a certas coisas, sendo elas justas ${ }^{263}$, ele deve cumprir o acordo ou enganar$\mathrm{se}^{264}$ ?

Cr. Cumprir.

So. A partir especificamente disso ${ }^{265}$, examine: nós, indo embora daqui sem ter persuadido ${ }^{266}$ a cidade, fazemos mal a alguns, mais precisamente (50a), aos que menos devemos fazer ${ }^{267}$, ou não? Permanecemos também com estes princípios quanto aos quais ${ }^{268}$ nos pusemos de acordo, sendo eles justos, ou não?

Cr. Não posso, Sócrates, responder o que você me pergunta, pois não compreendo. 
So. Pois bem, examine dessa forma ${ }^{269}$. Se a nós, que estamos prestes a fugir daqui - ou da maneira que se deve nomear isso ${ }^{270}$ - as leis e o interesse comum da pólis ${ }^{271}$ viessem, aparecessem e perguntassem" 272 "Diga-me, Sócrates, o que você tem em mente fazer? Não é verdade que ${ }^{273}$, com este ato que $\mathrm{e}^{274}$ você empreende, você planeja (50b) destruir, tanto quanto the $\mathrm{cabe}^{275}$, a nós, as leis, e a cidade como um todo? Ou você julga que seja possível que aquela cidade ainda exista e não esteja arruinada, aquela na qual $^{276}$ as decisões judiciais proferidas ${ }^{277}$ não prevaleçam, mas, por intermédio de homens, no âmbito de seus interesses particulares ${ }^{278}$, tornemse sem efeito e sejam destruídas?". O que responderemos ${ }^{279}$, Críton, a estas coisas e outras afins? Porque alguém, Críton, especialmente um orador ${ }^{280}$, poderia falar muito em defesa dessa lei que está sendo destruída, a qual ordena que as decisões dos casos julgados sejam (50c) soberanas. Ou nós lhes diremos: "Sim, tentaremos isso, porque a cidade foi injusta conosco ${ }^{281}$ e não aplicou corretamente a justiça"? Diremos isso ou o quê?

Cr. Isso, por Zeus, Sócrates.

So. O que, então, diremos se as leis disserem ${ }^{282}$ : "Sócrates, foi isso" ${ }^{283}$ realmente o que foi acordado entre nós e você ou o acordo era permanecer nas decisões que a cidade vier a julgar ${ }^{284}$ ?”. Se, então, ficássemos admirados com o que elas disseram, elas talvez dissessem: "Sócrates, não fique admirado com o que dizemos, mas responda, já que você também está acostumado a fazer uso do perguntar e responder. Bem ${ }^{285}$, por que, acusando (50d) a nós e a cidade, você tenta destruir-nos? Em primeiro $\operatorname{lugar}^{286}$, nós não o geramos, ou melhor ${ }^{287}$, não foi por nosso intermédio que o seu pai tomou a sua mãe como esposa e o engendrou? Diga, então, a estas dentre nós - as leis acerca do casamento - você as censura em algo sob o pretexto de que não sejam boas ${ }^{288}$ ?". "Não censuro", eu diria. "E 
quanto $^{289}$ àquelas a respeito da nutrição de quem nasceu e de sua educação, na qual você também foi educado? Não comandavam bem as leis dentre nós designadas para isso ${ }^{290}$, exortando o seu pai a educá-lo em música e (50e) ginástica?". "Comandavam”, eu diria. "Bem, depois que nasceu e foi nutrido e educado, você poderia dizer, em primeiro lugar, que, a seu ver ${ }^{291}$, não era nosso filho ou escravo ${ }^{292}$, nem você nem seus ancestrais? E se isso é assim, você considera que o justo exista a partir de uma igualdade ${ }^{293}$ para você e para nós, mais precisamente ${ }^{294}$, aquilo que tentarmos fazer-lhe você considera que seja justo também para você fazer de volta em represália? Ou, por um lado ${ }^{295}$, como era evidente ${ }^{296}$, em relação ao seu pai e ao seu senhor - se por acaso você teve um - o justo não existia a partir de uma igualdade, de modo que ${ }^{297}$ você também fizesse de volta em represália precisamente o que sofresse ${ }^{298}$, ou seja ${ }^{299}$, (51a) não era justo nem que, se falavam mal de você, você respondesse nem que, se fosse atacado ${ }^{300}$, contra-atacasse nem que fizesse muitas coisas semelhantes a estas. Mas, por outro lado, em relação à pátria e às leis, como se evidencia ${ }^{301}$, será permitido a você fazer tudo isso ${ }^{302}$, de modo que, se nós tentarmos destruílo, considerando que isso seja justo, você também ${ }^{303}$, tanto quanto for capaz, tentará destruir-nos, às leis e à pátria, e dirá que, fazendo isso, pratica ações justas, você que verdadeiramente cuida da virtude ${ }^{304}$ ? Ou você é tão sábio que não notou ${ }^{305}$ que a pátria ${ }^{306}$ é mais preciosa que a mãe, o pai e todos os outros ancestrais? Que ela também é mais venerável, mais sagrada $^{307}$ e é a que tem o maior (51b) quinhão ${ }^{308}$ tanto junto aos deuses quanto aos homens sensatos ${ }^{309}$ ? Que se deve, quando ela ${ }^{310}$ ficar irritada, tratá-la com mais honra, obediência e subserviência que ao pai? E que se deve ou persuadi-la $\mathrm{a}^{311}$ ou fazer o que ela ordenar ${ }^{312}$, e sofrer, sempre que ela mandar que sofra algo, sem retrucar? Que, sempre que ela mandar que 
você seja atacado, que fique preso, que vá à guerra para ser ferido ou morto $^{313}$, deve-se fazer essas coisas, e isso é o justo? E que não se deve desistir nem se retirar nem abandonar o posto, mas, na guerra, no tribunal, em todos os lugares ${ }^{314}$, deve-se ou fazer o que a pólis e a pátria ordenarem ou persuadi-la ${ }^{315}$ do modo como é naturalmente justo ${ }^{316}$ ? Que é ímpio usar a força $\mathrm{a}^{317}$ (51c) tanto contra o pai quanto contra a mãe, mas, muito pior ainda do que contra estes, é usar a força contra a pátria?" O que lhes diremos com relação a essas questões, Críton? Que as leis dizem a verdade ou não?

Cr. Eu, ao menos, julgo que dizem.

So. "Examine agora ${ }^{318}$, Sócrates", talvez as leis dissessem, "se dizemos a verdade quanto a isso: não é justo o que você tenta fazer conosco agora ${ }^{319}$, pois nós, depois de o ter gerado, criado, educado e compartilhado tudo de bom que pudemos compartilhar com você e com os demais cidadãos (51d), não obstante declaramos publicamente ${ }^{320}$, por ter dado permissão a quem dos atenienses desejasse, quando se tornasse um efebo ${ }^{321}$ e observasse os assuntos na cidade e a nós, as leis, que era permitido a quem não agradássemos que fosse embora, levando consigo os seus pertences, para onde quisesse. Além disso ${ }^{322}$, nenhuma de nós, as leis, está no caminho nem proíbe que alguém, mantendo os seus pertences, vá aonde quiser, seja a uma colônia ateniense, caso nós e a cidade não lhe tenhamos agradado, seja a outro lugar qualquer (51e), para viver como meteco ${ }^{323}$. Porém ${ }^{324}$ agora afirmamos que quem de vocês quiser permanecer, observando o modo como nós aplicamos a justiça e administramos a cidade quanto às outras coisas, que este homem ai ${ }^{325}$, estabeleceu um acordo conosco, por seus atos, que faria o que ordenássemos ${ }^{326}$. Além disso ${ }^{327}$, afirmamos que quem quer que não obedeça ${ }^{328}$ comete uma injustiça de três formas: porque 
não obedece a nós, que o geramos; porque não obedece a quem o criou; e porque, tendo concordado conosco em obedecer, nem nos obedece nem nos persuade, se não estamos fazendo algo bem. Embora nós tenhamos dado uma escolha, persuadir ${ }^{329}$ ou fazer - não ordenado selvagemente que fizesse aquilo que (52a) ordenássemos, mas permitido uma das duas alternativas nenhuma destas faz ${ }^{330 " \text {. "A estas acusações }}{ }^{331}$, Sócrates, afirmamos que você também estará sujeito se realmente fizer o que tem em mente. E você estará, entre os atenienses, não menos, mas mais sujeito do que a maioria ${ }^{332 " . ~ S e, ~ e n t a ̃ o, ~ e u ~ p e r g u n t a s s e ~ " P o r ~ q u e ̂ ? ", ~ e l a s ~ t a l v e z ~ j u s t a m e n t e ~}$ me censurassem, dizendo que eu, mais do que a maioria ${ }^{333}$ dos atenienses, tinha firmado com elas este acordo. Porque (52b) diriam: "Sócrates, para nós há grandes indícios de que ${ }^{334}$ nós e a cidade lhe agradávamos. Porque, de outro modo ${ }^{335}$, você nunca permaneceria nela mais do que todos os outros atenienses ${ }^{336}$ se não estivesse mais satisfeito com ela que todos os demais $^{337}$ : você nunca saiu da cidade para assistir aos festivais ${ }^{338}$, exceto ${ }^{339}$ uma vez para assistir aos de Istmo; nem para ir a nenhum outro lugar em outro tempo, exceto para servir como soldado ${ }^{340}$; nem nunca teve outra ausência, como os demais homens; e, além disso, não ${ }^{341}$ o tomou o desejo de outra cidade ou de outras leis, de conhecê-las ${ }^{342}$. Ao contrário ${ }^{343}$, nós e a nossa cidade the fomos suficientes: você nos escolheu com muita veemência; (52c) concordou em viver como cidadão de acordo conosco; e, particularmente ${ }^{344}$, nela criou os seus filhos, já que, a seu ver, ${ }^{345}$ a cidade lhe agradava. $\mathrm{E}$ ainda ${ }^{346}$, foi-lhe permitido no seu julgamento propor $\mathrm{o}$ exílio como pena, se desejasse, e fazer, na ocasião, com o consentimento da cidade, precisamente isso que você tenta fazer agora sem o consentimento dela. Você, na ocasião ${ }^{347}$, porém, vangloriou-se $\mathrm{e}^{348}$ de que não ficaria indignado se tivesse de morrer, $\mathrm{e}^{349}$ escolheu, como você disse, a morte em 
vez do exílio. Mas agora não se envergonha na frente de seus $\operatorname{argumentos}^{350}$ nem mostra respeito por nós, as leis, tentando nos destruir, $\operatorname{mas}^{351}$ faz exatamente aquilo que o escravo mais insignificante (52d) faria, tentando fugir, contrariamente às convenções e acordos segundo os quais ${ }^{352}$ acordou conosco viver como cidadão. Primeiramente, então ${ }^{353}$, respondanos isso, se dizemos ou não a verdade, afirmando que você tinha concordado em viver como cidadão não com palavras, mas por seus $\operatorname{atos}^{354}$." O que devemos dizer-lhes, Críton? Não é verdade que ${ }^{355}$ devemos concordar?

Cr. Necessariamente, Sócrates.

So. "Não é verdade, então", diriam, "que você está transgredindo as convenções e os acordos feitos especificamente $\operatorname{conosco}^{356}$, embora não (52e) tenha concordado sob coerção nem tenha sido enganado nem constrangido $^{357}$ a decidir em pouco tempo, mas em setenta anos, nos quais lhe foi permitido ir embora se nós não lhe agradássemos e você julgasse que os acordos não eram justos? Você não preferiu nem Esparta nem Creta, aquelas mesmas que $\mathrm{e}^{358} \mathrm{em}$ todas as ocasiões você afirma que têm leis bem estabelecidas $^{359}$, nem nenhuma outra das cidades helenas ou (53a) bárbaras, mas, pelo contrário ${ }^{360}$, você ficou ausente dela menos que os aleijados, os cegos e os demais incapacitados. É evidente que você ficou satisfeito com a cidade e também ${ }^{361}$ conosco, as leis, muito mais do que todos os demais ${ }^{362}$, pois a quem uma cidade sem leis agradaria? E agora, depois de tudo ${ }^{363}$, você não permanecerá fiel àquilo que tínhamos acordado? Permanecerá, se se deixar persuadir por nós ${ }^{364}$, Sócrates; e, ao menos, não será digno de riso por ter saído da cidade.

Examine com atenção ${ }^{365}$ : transgredindo tudo isso e cometendo aí um erro, que bem você fará a si mesmo ou aos (53b) seus amigos? Porque é 
quase certo que $\mathrm{e}^{366}$ os seus amigos, também eles, estarão expostos a riscos: ao risco $\mathrm{de}^{367}$ serem exilados, privados da cidade ou de perderem a propriedade. Em primeiro lugar ${ }^{368}$, se for a uma das cidades mais próximas, Tebas ou Megara, já que ambas têm leis bem estabelecidas, você chegará, Sócrates, como inimigo para o governo delas, e todos que cuidam de suas próprias cidades o desprezarão, considerando-o corruptor das leis. Além disso, você confirmará o juízo ${ }^{369}$ dos juizes $^{370}$, de modo a julgarem (53c) que a sentença foi dada corretamente, pois quem é um corruptor de leis seria, presumo, certamente reputado como um corruptor de jovens ${ }^{371}$ e de homens insensatos. Evitará, então, as cidades com boas leis e os homens mais bem organizados? E, fazendo isso, para você valerá a pena viver? $\mathrm{Ou}$ você se aproximará deles e não terá vergonha de dialogar? Sobre quais assuntos, Sócrates? Seriam exatamente os daqui ${ }^{372}$, dizendo que, a seu ver, a virtude e a justiça valem muito para os homens, assim como os costumes e as leis ${ }^{373}$ ? E você não considera que a conduta de (53d) Sócrates se mostraria indecorosa? Você certamente deve considerar que $\operatorname{sim}^{374}$ ! Ao invés disso ${ }^{375}$, você se distanciará desses lugares ${ }^{376}$ e chegará à Tessália até os amigos de Críton? Porque, sem dúvida ${ }^{377}$, lá há muita desordem e intemperança $^{378}$, e talvez ouçam com prazer como você ${ }^{379}$ fugiu da prisão de modo ridículo: vestindo um disfarce - com uma pele de carneiro ou com outras coisas do tipo com que ${ }^{380}$ costumam disfarçar-se os fugitivos - e mudando a sua aparência. Não haverá ninguém que ${ }^{381}$ dirá que você, um homem velho, tendo, provavelmente, pouco tempo de vida, ousou desejar viver tão tenazmente, tendo (53e) transgredido as maiores leis ${ }^{382}$ ? Talvez, se você não perturbar ninguém. Caso contrário, você ouvirá, Sócrates, muitas coisas indignas de você $\hat{e}^{383}$. Você, certamente ${ }^{384}$, viverá bajulando todos os homens e sujeitando-se como um escravo. Que outra coisa você 
ficará fazendo ${ }^{385}$ na Tessália a não ser festejando, como se tivesse ido até lá para jantar? E aquelas discussões sobre a justiça e as outras virtudes, perguntamos ${ }^{386}$, onde estarão (54a)? Ora, mas você dirá certamente que $\mathrm{e}^{387}$ quer viver por causa dos filhos, para nutri-los e educá-los? Você fala sério $^{388}$ ? Se os levar à Tessália, você os nutrirá e educará, depois de tornálos estrangeiros, para que disso usufruam ${ }^{389}$ também? Ou isso não ocorrerá $^{390}$, mas sendo nutridos aqui mesmo, enquanto você vive, serão mais bem nutridos e educados, sem que você esteja com eles ${ }^{391}$ ? Sim, eles serão ${ }^{392}$, pois os seus amigos cuidarão deles. $\mathrm{Ou}^{393}$ cuidarão deles se você partir para a Tessália, mas, se partir para o Hades, não? Se, ao menos, há realmente alguma utilidade ${ }^{394}$ para os que lhe dizem que são seus amigos, você certamente deve considerar (54b) que $\operatorname{sim}^{395}$ !". "Vamos ${ }^{396}$, Sócrates, deixando-se persuadir por nós ${ }^{397}$ que o nutrimos, não valorize mais os filhos nem o viver nem qualquer outra coisa antes do justo, para que, chegando ao Hades, você possa apresentar, em sua defesa, essas coisas aos que lá governam. Porque, se você fizer isso, o proposto por Críton $^{398}$, nem aqui parece que seja melhor ou mais justo ou mais pio para você, ou para qualquer um dos seus, nem lá, quando chegar, será melhor para você ${ }^{399}$. Agora, no entanto, se você partir, partirá, sendo injustiçado não por nós, as leis, mas pelos (54c) homens; mas, se sair tão vergonhosamente, tendo revidado uma injustiça com uma injustiça ou um mal com um mal, tendo transgredido os seus acordos e o convencionado conosco, e tendo feito mal a estes a quem menos deveria fazer - a si mesmo, aos amigos, ao país e a nós - nós ficaremos irritadas com você enquanto viver, e lá, no outro mundo, as nossas irmãs, as leis no Hades, não o receberão gentilmente, sabendo que, $(54 \mathrm{~d})$ dentro das suas possibilidades ${ }^{400}$, você tentou destruir 
inclusive a nós ${ }^{401}$. Bem, tomara ${ }^{402}$ que Críton não o persuada ${ }^{403}$, mais do que nós, a fazer o que ele diz."

A isso, querido amigo Críton, esteja certo que julgo ouvir como aqueles tomados pelo entusiasmo coribântico julgam ouvir flautas ${ }^{404}$, e em mim o som destes argumentos ressoa e torna impossível ouvir outros ${ }^{405}$. E tenha em mente que ${ }^{406}$, dentro do que são meus julgamentos agora ${ }^{407}$, se você falar contra estes, falará em vão. No entanto ${ }^{408}$, se você considera que pode ser bem sucedido, diga.

Cr. Ora, Sócrates, não posso dizer mais nada.

So. Por isso, Críton, ceda e façamos assim, já que assim o deus conduz. 


\section{Notas}

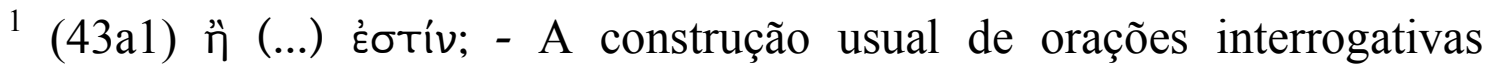

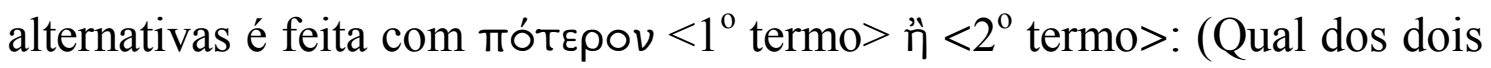
ocorre: $\mathrm{o}<1^{\mathrm{o}}$ termo $>$ ou $<2^{\circ}$ termo $>$ ?). No entanto, ク̈, em lugar de preceder o $2^{\circ}$ termo, pode iniciar uma interrogação simples, quando se requer da outra parte, com mais insistência, uma resposta esperada a uma primeira questão ou o consentimento a alguma afirmação anterior (BIZOS, pp. 150). Neste caso, por conta de sua pergunta anterior, denotando estranhamento quanto à presença de Críton àquela hora, podemos supor que Sócrates espera que ele confirme que ainda não é o horário usual de visitas, que sabemos pelo Fédon (59 d1 ss) que não era de manhã cedo (59 d6-7

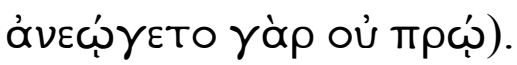

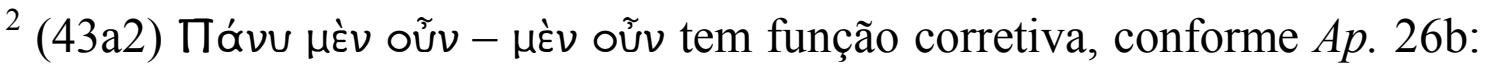
'imo, valde quidem' (PLATO, 1997a, pp. 22): 'De fato, é muito cedo'. Repetirei, no final de muitas das notas, a tradução que efetuei das expressões que destaquei para que se torne mais fácil encontrá-las no texto do Críton.

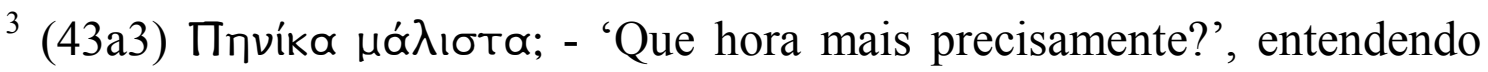
'hora' no seu sentido antigo, que era 'período do dia' (manhã, tarde, noite etc), já que a divisão do dia em 24 horas é posterior ao período clássico (LSJ, pp. 2035).

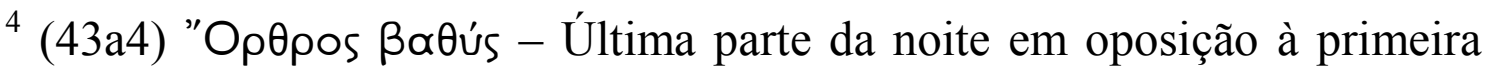

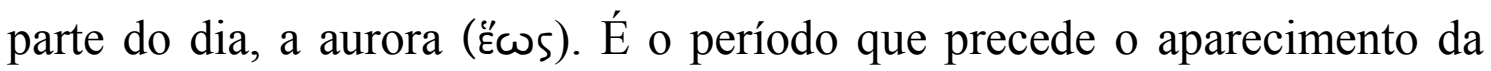
primeira claridade que aponta o início da manhã (PLATO, 1979, pp. 254).

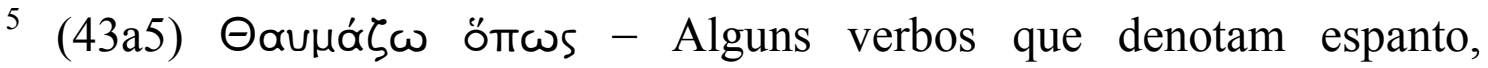
indignação etc podem ter como complemento uma interrogativa indireta 


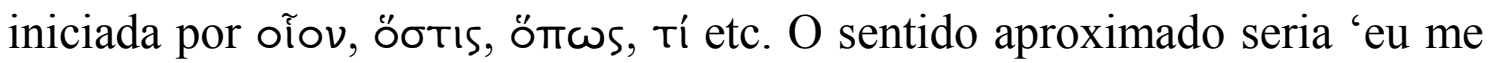
admiro como ...'. (BIZOS, pp. 144).

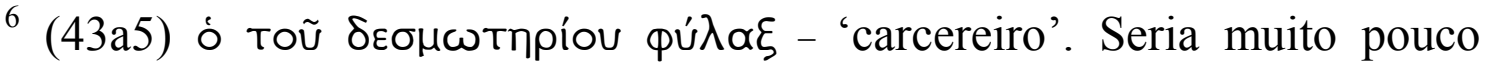
provável que se tratasse do porteiro que aparece no início do Fédon (Phd. 59e4), ó Oupwpós, já que ele não estaria de serviço a esta hora. Para autorizar visitas fora do horário, o tal carcereiro deve ser um funcionário dos Onze, que eram os responsáveis pela administração da prisão (PLATO, 2001a, pp. 46) (PLATO, 1979, pp. 255).

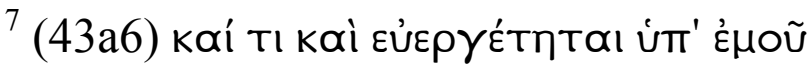

- kái Tı kaì - O primeiro kaí é uma conjunção aditiva, 'e', e o segundo, um advérbio, 'ademais' [(PLATO, 1979, pp. 255) e (PLATO, 2001a, pp. 46)].

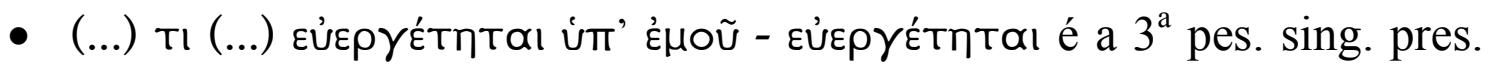

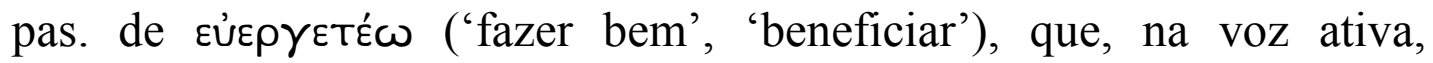
constrói-se com dois acusativos: um de objeto externo, referente à pessoa beneficiada, e outro interno, referente à coisa de que se beneficiou. Verbos que possuem esta regência, quando transformados na voz passiva, retêm o acusativo de objeto interno, enquanto que o externo torna-se o nominativo na construção passiva (GG, sec. 1591,

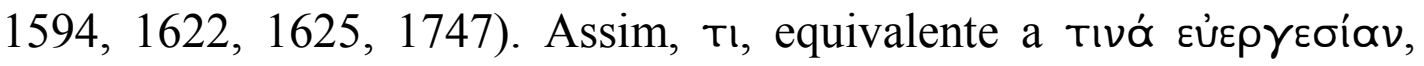
'um benefício', 'um agrado', é o acusativo de objeto interno de

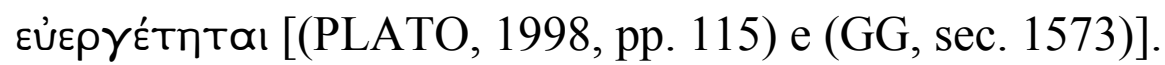

8 (43b1) Eĩta - 'então, nesse caso' - Advérbio denotando conseqüência, principalmente em exclamações que expressam surpresa, neste caso,

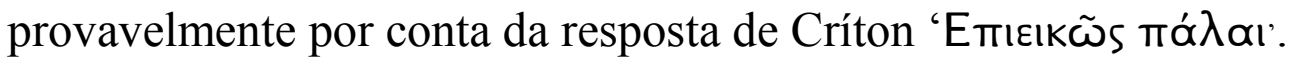

${ }^{9}$ (43b1) à $\lambda \lambda \grave{\alpha}$ - Conjunção que está marcando uma forte oposição entre as duas sentenças (GP, pp. 1), daí a escolha por traduzi-la por 'ao invés de'. 


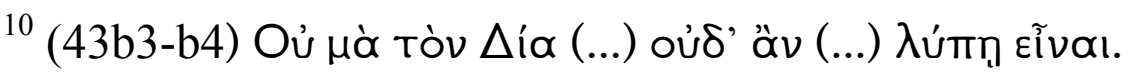

- Oủ nà tòv $\Delta i ́ \alpha$ - expressão idiomática: 'Não, por Zeus!'. Críton

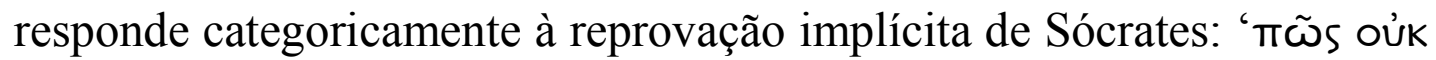

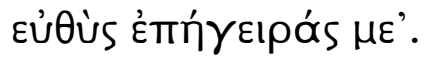

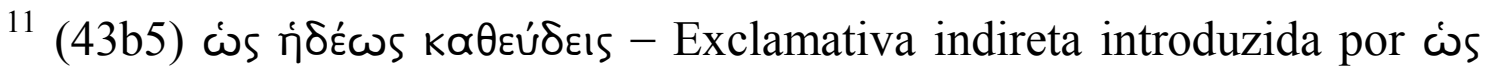

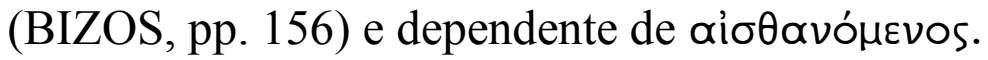

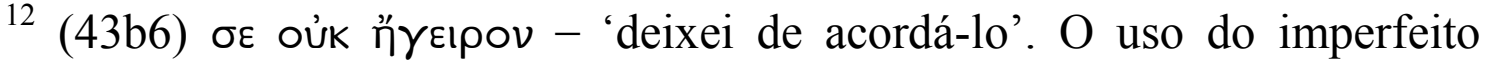
mostra a firmeza do propósito de Críton: se Platão tivesse usado o aoristo,

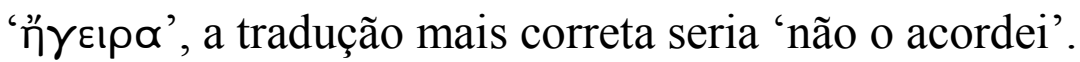

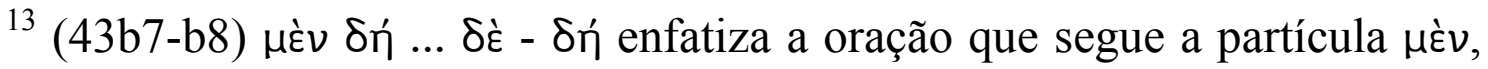
no par antitético $\mu \dot{\varepsilon} \nu . . . \delta \dot{\varepsilon}$ (GP, pp. 257-258).

${ }^{14}$ (43b10) Kài Yà - Forte assentimento, como se Sócrates estivesse descartando o contrário como se fosse absurdo (PLATO, 2001a, pp. 47): 'com certeza, pois (...)'

15 (43b10) $\pi \lambda \eta \mu \mu \varepsilon \lambda \dot{\varepsilon} s$ - adjetivo, que, literalmente, significa destoante, desafinado. Metaforicamente pode ser visto como algo que foge aos pressupostos, uma incoerência. Conforme Ap. 22 d8, ' $\dot{\eta} \pi \lambda \eta \mu \mu \varepsilon ́ \lambda \varepsilon ı \alpha$

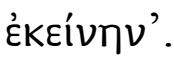

${ }^{16}$ (43b11) $\delta \varepsilon \tilde{~}$ - Deve-se notar a ambigüidade da construção utilizada por

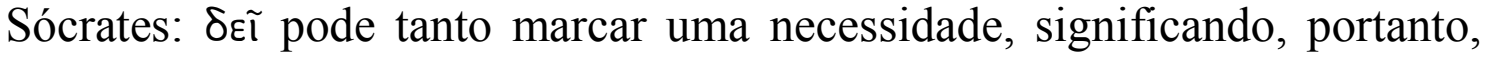
que Sócrates não tem escolha a não ser conformar-se diante da morte iminente, quanto uma obrigação moral, significando, nesse caso, que ele poderia, se quisesse, fugir. A tradução de $\delta \varepsilon \tilde{~} \tau \varepsilon \lambda \varepsilon \cup \tau \tilde{\alpha} \nu$ por 'devo morrer' mantém em português essa ambigüidade.

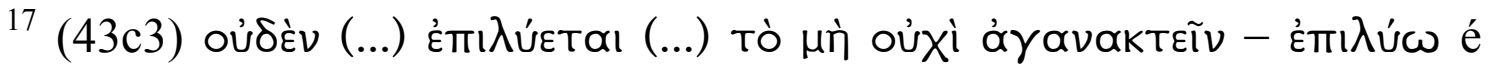
construído como se fosse um verbo que comunica a idéia de impedimento: com tò $\mu$ (т̀ (Tò $\mu$ oú, caso o verbo da oração principal esteja acompanhado 
de alguma partícula negativa) seguido de um verbo no infinitivo (SMTGV, pp. 198-202). Segundo Burnet, esta construção do verbo Émı $\lambda u ́ \omega$ é única na literatura grega (PLATO, 1979, pp. 256).

${ }^{18}$ (43c4) $\dot{\alpha} \lambda \lambda \grave{\alpha}$ - Utilizado por Sócrates para marcar o encerramento do assunto iniciado por Críton em $43 \mathrm{~b} 3$ e a retomada da pergunta que ele fez em $43 \mathrm{~b} 1$.

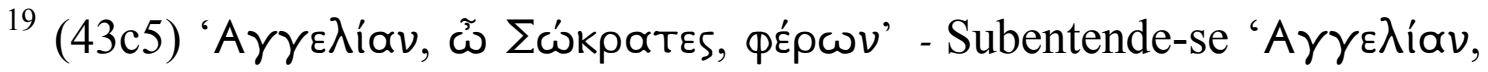

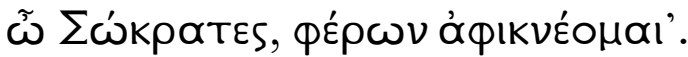

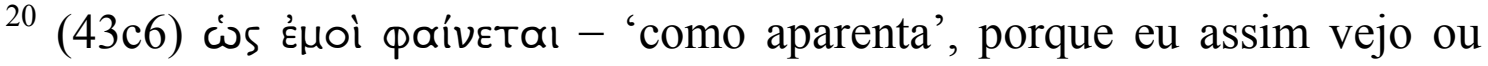
sinto.

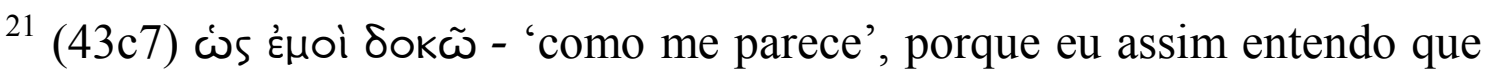
seja, isto é, 'como eu julgo'.

${ }^{22}$ (43c7) غ̇ ${ }^{2}$ Toĩs, anteposto a um advérbio (ou a um adjetivo) no grau superlativo, confere-lhe uma força maior ainda (GG, sec. 1089). Segundo

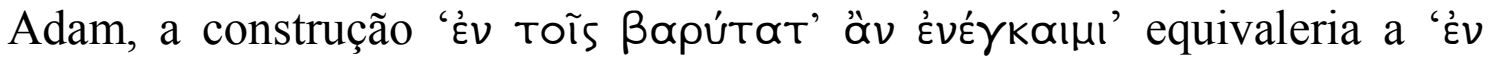

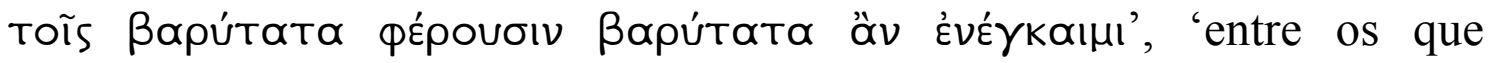
suportam com pesar, eu suportaria com extremo pesar', ou seja, algo próximo a 'poucos suportariam tão penosamente quanto eu'.

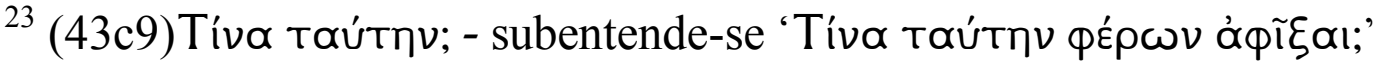

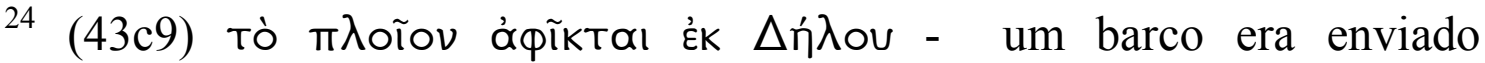
anualmente a Delos em celebração ao retorno de Teseu a Atenas vindo de Creta, ocasião em que este matou o Minotauro e salvou os jovens, que o acompanhavam na missão, de serem devorados pelo monstro. $\mathrm{O}$ barco em questão havia partido no dia anterior ao julgamento de Sócrates e, enquanto estivesse fora, a cidade deveria manter-se pura, o que suspendia todas as execuções de criminosos. Como a viagem demorava em torno de 30 dias, 
Sócrates teve de aguardar preso o momento de sua execução (Phd. 58a-c e Xen. Mem. iv 82).

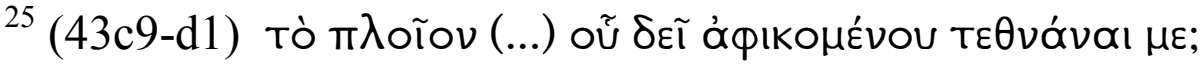

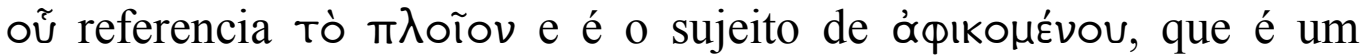

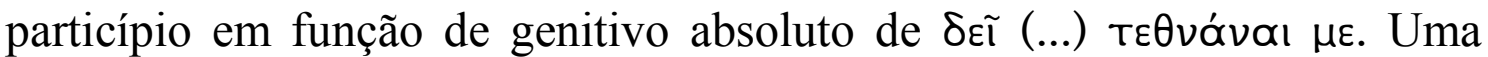
subordinção deste tipo é pouco usual em português, principalmente em diálogos informais, mesmo assim resolvi imitá-la na tradução, após consultar as soluções dadas por outros tradutores:

- Fowler - 'Has the ship come from Delos, at the arrival of which I am to die?' (PLATO, 2001b, pp. 153).

- Croiset - 'M'annonces-tu le retour du navire, revenant de Delos, à l'arrivée duquel je dois morrir?' (PLATON, 2002, pp. 217).

- Campos - 'Chegou de Delos a embarcação por ocasião de cuja chegada devo morrer?' (PLATÃO, 2008, pp.114).

- Pulquério - 'Será que acaba de chegar de Delos o navio, de cuja chegada depende a data da minha morte?' (PLATÃO, 2002, pp. 63)

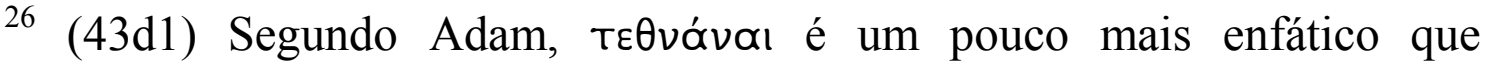

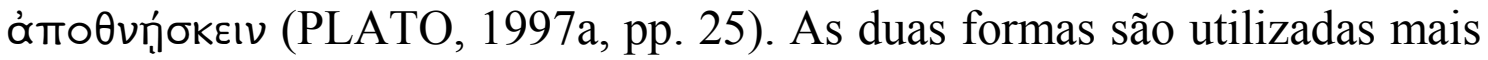
de uma vez no Críton e parece-me difícil diferenciá-las.

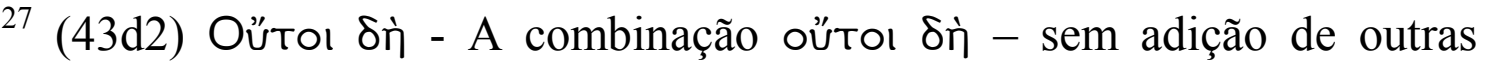
partículas - é vista somente em Platão (GP, pp. 552). Em geral, não há muita coesão nas combinações de tol com outras partículas: toı remete, em um diálogo, a questão ou o assunto ao outro com quem se dialoga

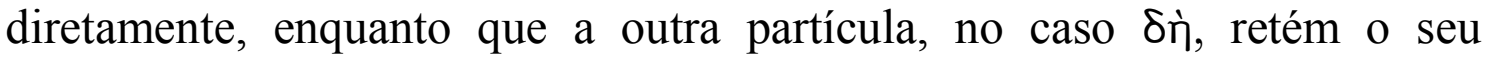
sentido usual (aqui intensivo) (GP, pp. 548-549): 'Bem, de fato não chegou 


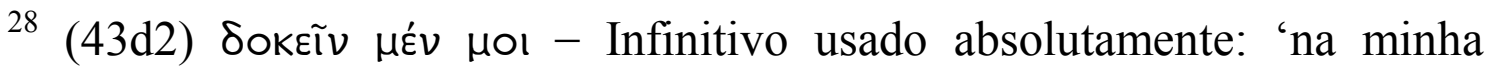

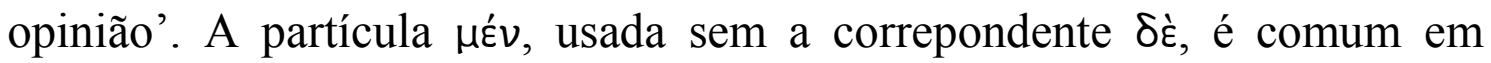
construções que involvam verbos que denotam opinião: o contraste é feito implicitamente, no caso, com o que se postula como fato.

${ }^{29}$ (43d3) Segundo Adam, o Cabo Súnio era uma importante referência para os navegadores na costa sul da Ática (PLATO, 1997a, pp. 25).

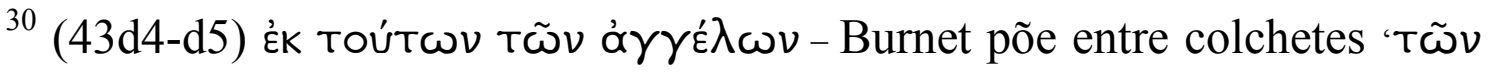

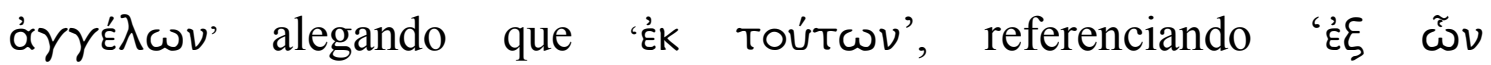

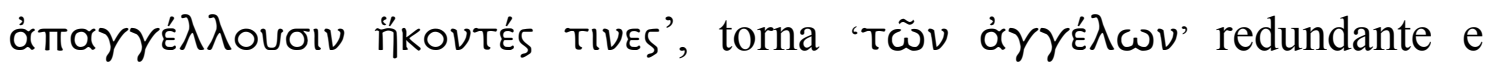
desnecessário (PLATO, 1979, pp. 257). A espressão, no entanto, foi mantida pela OCT.

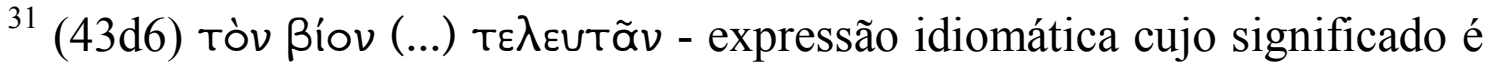
aproximadamente o mesmo de т $\varepsilon \theta v$ óvå: 'que a sua vida chegue ao fim'.

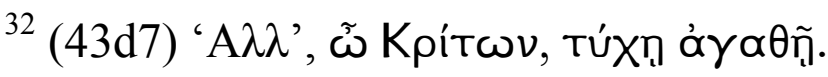

- $\alpha \lambda \lambda \lambda \dot{\alpha}$ - marca a transição de um presente conhecido para um futuro incerto, mas desejado (GP, pp. 15-16) - 'Tomara'.

33 (44a2) Yáp mou - usado freqüentemente por Platão quando busca a concordância da outra parte em relação ao que se afirma (GP, pp. 494).

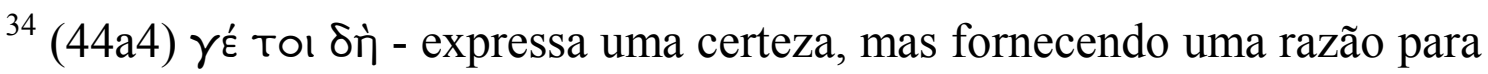
tal (GP, pp. 550-551) - 'Sem dúvida! ao menos, ...'.

35 (44a4) oi toútwv kúpıo - 'os que tem autoridade sobre isso', isto é, 'os Onze'.

${ }^{36}$ (44a5) Toívuv - introduz uma réplica que deriva diretamente, na opinião de quem fala, da resposta dada pelo falante anterior (GP, pp. 569-570) 'por isso', 'assim', 'sendo assim'. 


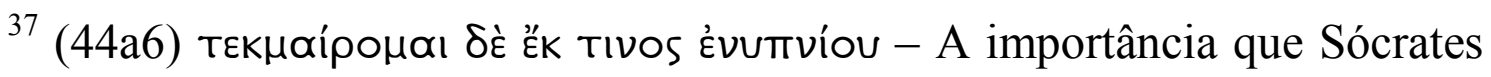

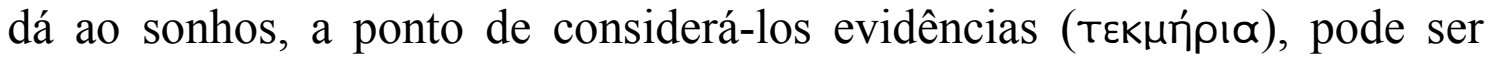
atestada também em sua defesa, $A p .33 \mathrm{c} 5$ e ss.

${ }^{38}$ (44a9) ${ }^{\text {T } H \nu ~ \delta \varepsilon ் ~ \delta i ̀ ~ T i ́ ~-~ e n f a t i z a ~ q u e ~ o ~ i n t e r e s s e ~ d e ~ C r i ́ t o n ~ e s t a ́ ~ n o ~ s o n h o ~ d e ~}$ Sócrates, não nas circunstâncias em que ele foi sonhado (GP, pp. 259). Adam nota que Críton não coloca o pronome interrogativo tí antes do verbo como seria o mais usual (PLATO, 1997a, pp. 27).

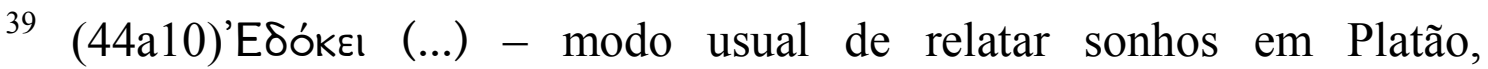
Aristófanes e Xenofonte (PLATO, 1979, pp. 257).

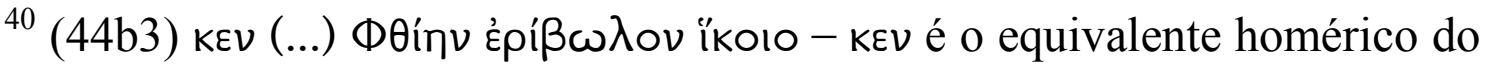
advérbio åk ático; o verbo íkoı é construído diretamente com um

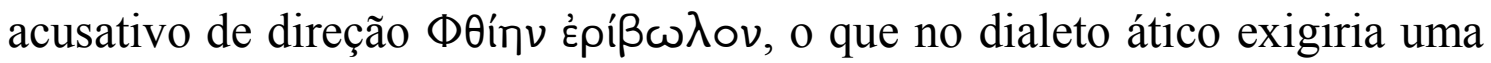
preposição.

${ }^{41}$ (44b3) A descrição do sonho feita por Sócrates é uma adaptação do trecho Il. IX, 363 em que Aquiles menciona a possibilidade de voltar à sua

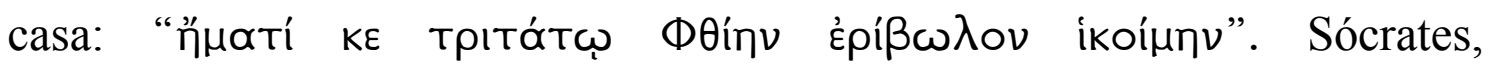
possivelmente, interpretou a fala da mulher de branco do sonho metaforicamente: a "chegada à fértil Ftia no terceiro dia" seria uma indicação clara de sua morte iminente. Porém, interpretada literalmente, tal fala poderia muito bem estar prevendo o exílio de Sócrates na Tessália, proposta que será feita por Críton pouco adiante, em $45 \mathrm{c} 2$, já que a Ftia era parte da Tessália.

Uma ambigüidade deste tipo no sonho relatado por Sócrates, percebida por Kramer (KRAMER, pp. 193-197), não pode ser desprezada. Ao fazer uma referência direta ao livro IX da Ilíada, Platão provavelmente pretendia estabelecer algum tipo de relação entre a cena narrada no livro em questão - a embaixada enviada pelo exército grego com o intuito de 
persuadir Aquiles a retornar à batalha - e a visita de Críton a Sócrates, que, como já adiantamos, tentará persuadi-lo a fugir da prisão.

Ainda no livro IX, em Il. IX 410-16, Aquiles explica aos presentes que sua mãe, a deusa Tétis, contara-lhe que seu destino não estava completamente traçado, cabendo-lhe uma escolha: ele poderia voltar à guerra e não voltar para casa, mas tendo uma glória imortal, ou voltar para casa e ter vida longa, mas sem nenhum renome. A decisão de Aquiles de vingar a morte de seu amigo Pátroclo, optando, conseqüentemente, pelo abreviamento de sua vida, como sabemos, somente ocorrerá no Livro XVIII, decisão, aliás, mencionada por Sócrates na sua defesa, Ap. 28b-d, e tida como correta e digna de ser imitada, o que mutatis mutandis foi o que ele fez em seu julgamento.

Para Kramer, o sonho, trazendo de volta o exemplo de Aquiles, faz o diálogo ganhar em dramaticidade, pois cria a expectativa de que, quase um mês depois de ter preferido a morte ao abandono da prática da filosofia, Sócrates terá que escolher de novo. Tal tese ganha ainda mais força quando analisamos mais detalhadamente o trecho do Livro IX a que o sonho se refere:

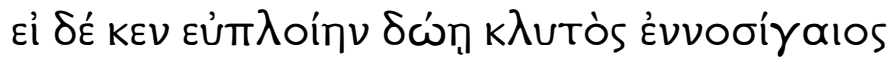

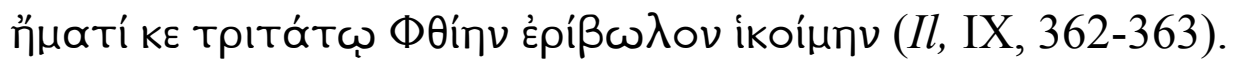

Se o glorioso Treme-Terra me conceder uma viagem tranqüila, no terceiro dia eu [poderia chegar/ chegarei] à fértil Ftia.

Trata-se de uma hipótese sobre o futuro, pois temos um verbo no subjuntivo ( $\delta \omega ́ n)$ precedido pela partícula $\kappa \varepsilon v$ na prótase, mas uma apódose com um valor ambíguo, pois nela há um verbo no optativo (íkoíunv) precedido também pela partícula $\kappa \varepsilon$, o que pode equivaler a uma forma atenuada de futuro do indicativo ou a uma possibilidade futura. A 
ambigüidade é quebrada pelo contexto, quando, por exemplo, Aquiles propõe:

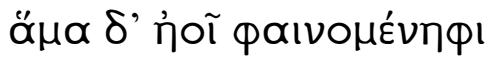

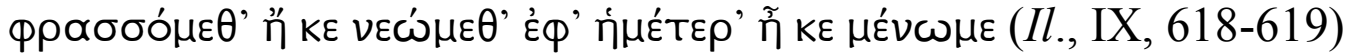

“Tão logo apareça o dia,

decidiremos se retornaremos às nossas [casas] ou se permaneceremos"

A apódose acima é, portanto, uma possibilidade futura, que, sabemos, não será exercida por Aquiles. Do mesmo modo, então, devemos

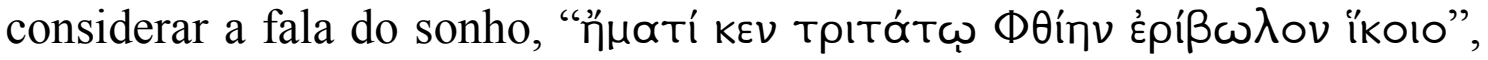
uma apódose cuja condição foi suprimida, mas que representa uma possibilidade futura que ainda está em aberto nesta etapa do diálogo.

${ }^{42}$ (44b4) ' $\omega_{\varsigma}$ - introduz uma sentença exclamativa (GG, sec. 2682).

${ }^{43}$ (44b5) $\mu \varepsilon \dot{\nu}$ oũv - oũv enfatiza a partícula $\mu \varepsilon \dot{v}$, que aqui tem um sentido adversativo (GP, pp. 475). Neste caso, Sócrates discorda enfaticamente da visão de Críton: 'Pelo contrário'.

${ }^{44}$ (44b5) Évapyès - 'claro, evidente'. Adjetivo comumente utilizado na qualificação de sonhos cujo significado é considerado evidente (PLATO, 2001a, pp. 50).

${ }^{45}$ (44b5) $\gamma \varepsilon ́$ - partícula aqui empregada com função limitativa: 'ao menos'

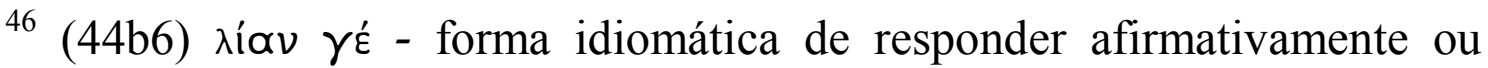
concordar com o que está sendo dito. Neste caso, por conta do advérbio $\lambda i ́ \alpha v$, 'muito', $\gamma$ '́ é uma partícula intensiva, assim podemos entender que Críton está acrescentando algo à afirmação feita por Sócrates (GP, 133134), que, penso, é a interpretação literal do sonho narrado. Ver notas $44 b 3$ e $45 \mathrm{c} 2$. 
${ }^{47}$ (44b6) $\dot{\alpha} \lambda \lambda \grave{\alpha}$ - Marca o encerramento de um assunto, como em 43c4. Apesar da semelhança, a meu ver, não se trata de um caso como em 45a3.

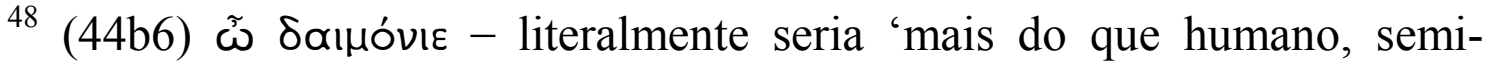
divino', mas aqui está sendo usado como sinal de afeição com um leve tom de reprovação (PLATO, 1997a, pp. 28) : 'divino'.

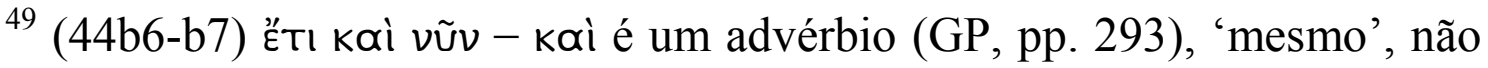
uma conjunção aditiva: 'ainda mesmo agora' ou somente 'mesmo agora'. Adam vê neste trecho e em 48e1-e3 fortes indícios de que ambos já tenham tido outras conversas sobre este mesmo tema.

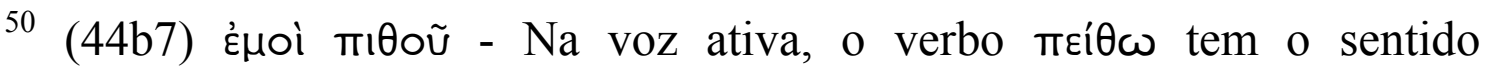
aproximado de "persuadir", com ênfase ora na tentativa de persuasão somente - "tentar persuadir" - ora no seu resultado - "convencer por meio

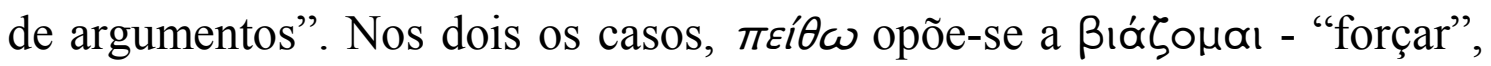
"submeter pela força". Na voz média ou na passiva, se for construído com um dativo pessoal, o verbo em questão pode ter o sentido aproximado de "ser persuadido por alguém", mas dependendo das circunstâncias, é melhor traduzido por "deixar-se persuadir por alguém", "acreditar em alguém" ou até por “obedecer a alguém”. Pode ainda, na voz média ou passiva, quando seguido ötı ou ẃs, ter o sentido de "acreditar que".

O verbo $\pi \varepsilon i \theta \omega$ aparece 22 vezes no Criton com todos os sentidos citados acima.

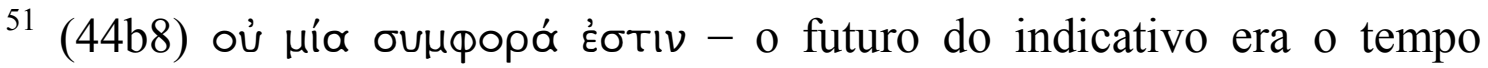
esperado na apódose quando a prótase contém um subjuntivo precedido do advérbio ő้v, marcando uma hipótese sobre o futuro. No entanto, o presente, dito de antecipação, é preferido nas condições em que se considera o que está por vir como certo ou muito provável (GG, sec. 1879). 


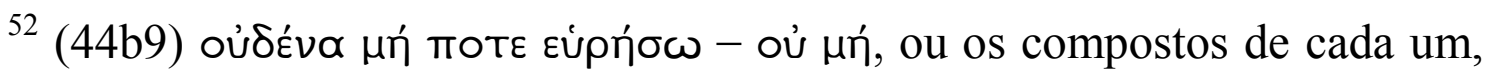
seguidos do futuro do indicativo, ou do subjuntivo, denotam uma negação forte (GG, sec 2755 b): 'com certeza nunca mais encontrarei'.

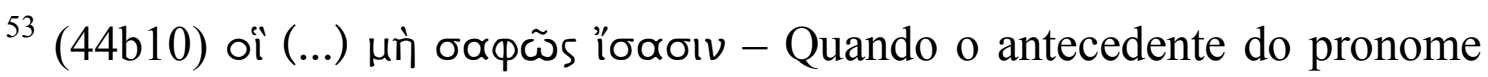
relativo é pensado em termos de suas características, isto é, quando é pensado não como alguém que faz algo, mas como alguém de um certo tipo ou que tipifica uma classe, como é o caso aqui - 'muitos que não conheçam bem nem a mim nem a você' - utiliza-se a negação $\mu$ (GG, sec. 2705 g).

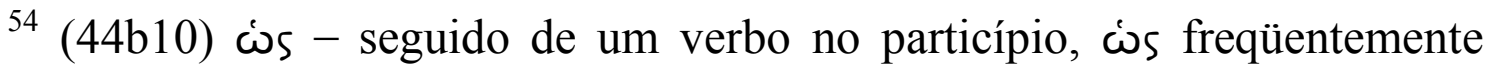
introduz uma causa alegada, não a verdadeira ou a endossada por quem fala: 'porque, alegariam, (...)'.

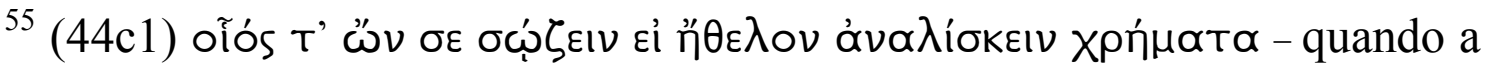
prótase é formada por um verbo no imperfeito do indicativo, marcando uma hipótese no presente que é considerada irrealizável, a apódose, mesmo se construída com um particípio ou infinitivo, normalmente contém o advérbio ơ̌ $v$. No entanto, diante de expressões impessoais indicando obrigação, possibilidade etc, costuma-se omitir tal advérbio. (GG, sec. 2313).

${ }^{56}$ (44c2) kaítol - partícula que marca, numa argumentação, a passagem de argumento para outro, freqüentemente na forma de uma pergunta (GP, pp.562-563): 'ora (...)'.

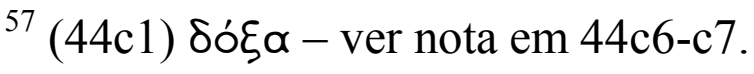

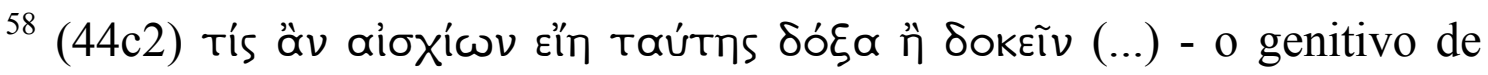
comparação, taútns, é explicado pela oração ī Sokeĩv (...), que funciona como um aposto [(GG, sec. 1075) \& (PLATO, 1979, pp. 259)]. Há uma variante, no entanto, citada pela OCT, a família P, que omite taútns.

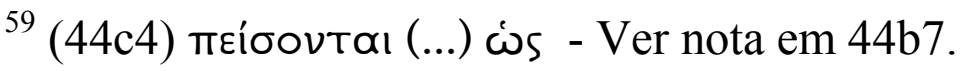




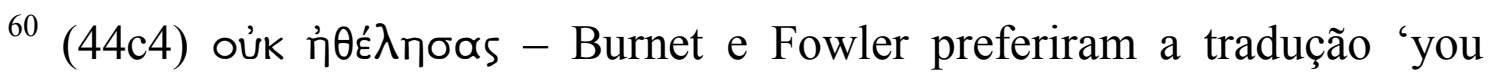
refused' - que eu também considero a melhor ante a escolha mais usual 'you did not want'[(PLATO, 1979, pp. 259) \& (PLATO, 2001b, pp. 155)].

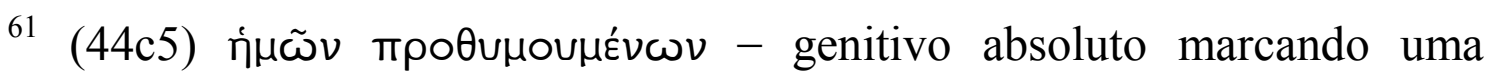
concessão: 'ainda que nós nos esforçássemos por isso'

${ }^{62}$ (44c6) $\alpha \lambda \lambda \lambda \grave{\alpha}$ - utilizado em respostas em objeção ao que acabou de ser dito pelo outro (GP, pp. 7): 'mas'.

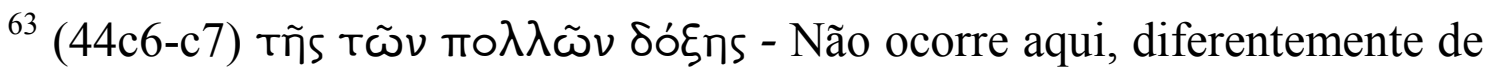
outros diálogos, em particular na República, uma oposição entre a $\delta o ́ \xi \alpha$,

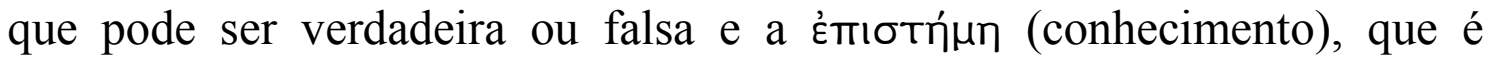
sempre verdadeira. A oposição existente no diálogo é entre '

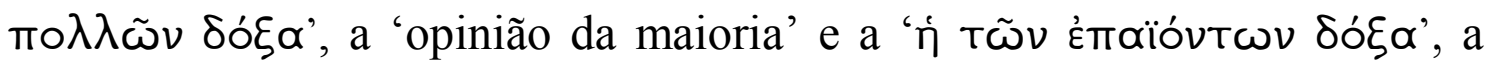
'opinião dos especialistas'. Porém, pelo fato de 'opinião' ser um termo marcado no vocabulário platônico, optei por traduzir $\delta o ́ \xi \alpha$, sempre que possível, por termos correlatos e não marcados, tais como 'juízo', 'reputação', 'crença' etc.

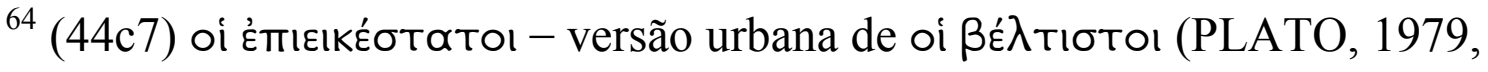
pp. 259), 'os melhores', 'os mais capazes', mas por deterem algum conhecimento, podendo englobar pessoas de quaisquer extratos. O termo é utilizado em Ap. 22a5, quando Sócrates, falando de sua missão divina,

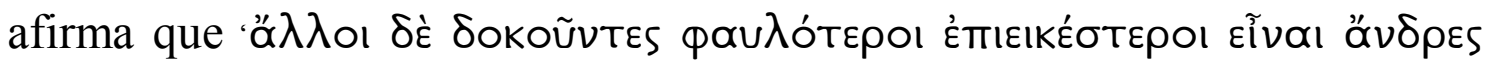

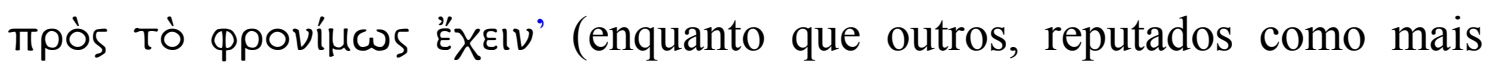
insignificantes, pareciam ser homens melhores com relação à sabedoria).

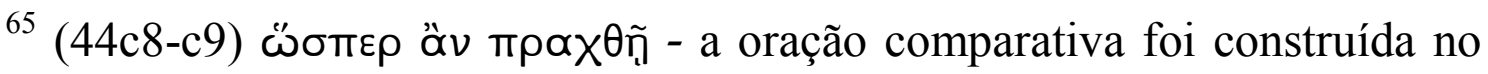
subjuntivo (eventual) porque Sócrates quis comunicar uma certa indefinição acerca do que será feito (GG, sec. 2475-2476), aumentando a dramaticidade da cena. 
${ }^{66}$ (44d1) à $\lambda \lambda \grave{\alpha}$ - ver nota 44c6.

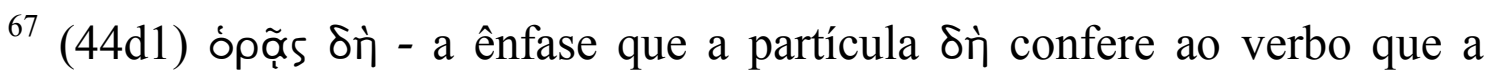
precede é de ordem mais intelectiva (GP, pp. 215): 'você certamente vê'.

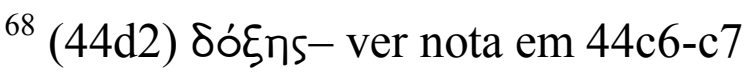

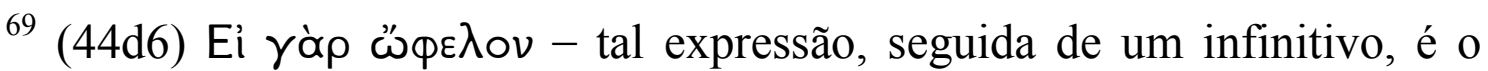
modo pelo qual o grego expressava um lamento ou um desejo irrealizável: 'Quem dera ...'

${ }^{70}$ (44d7) íva oĩoí T' ñoav - quando a oração principal representa um desejo frustrado, a oração final, introduzida nesse caso por ìva, tem o seu verbo em um tempo secundário do indicativo, indicando que o propósito que apresenta é inalcançável (GG, sec. 2185 c).

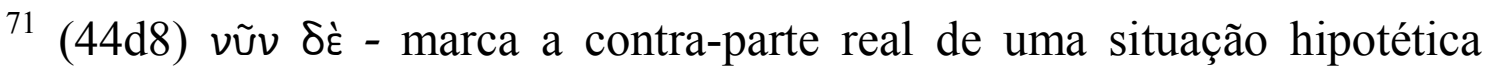

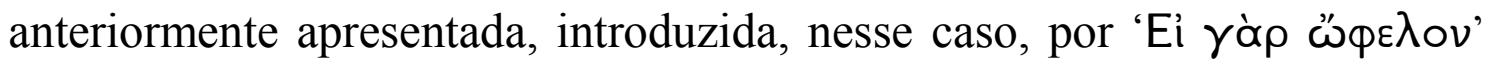
(GG, sec. 2924): 'mas, de fato'.

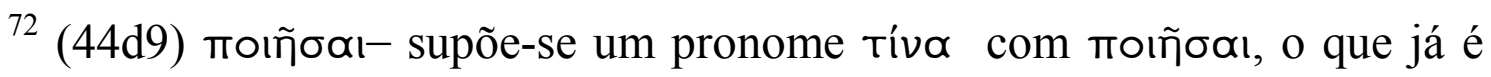
indiretamente sugerido pelo adjetivo öppova (acusativo masculino singular de ớ $\varphi \rho \omega \nu)$ : 'tornar alguém tolo'.

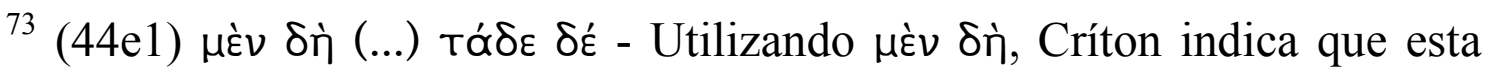
linha argumentativa, mais filosófica, trazida por Sócrates está encerrada, e busca uma nova, introduzida por Tód $\delta \varepsilon$ É (PLATO, 2001a, pp. 52-53): 'Que assim seja! Mas responda-me isto (...)'

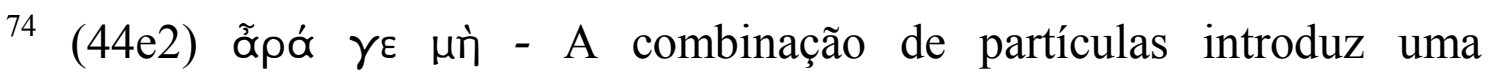
interrogação que não implica necessariamente a expectativa de uma resposta negativa, mas que a sugestão feita por ela é de difícil aceitação (GP, pp. 47-48 e 50): 'Ora (...) não (...) ?'.

75 (44e3) $\mu n ́$ - Os verbos que denotam medo ou apreensão, como

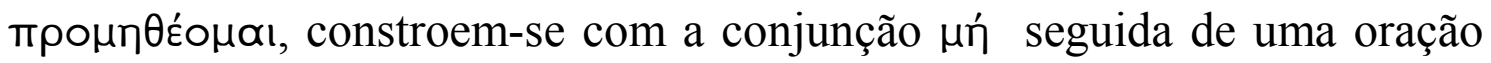




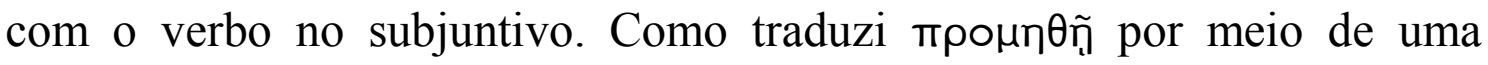
perífrase, 'está preocupado', para dar conta das pessoas que são objetos de

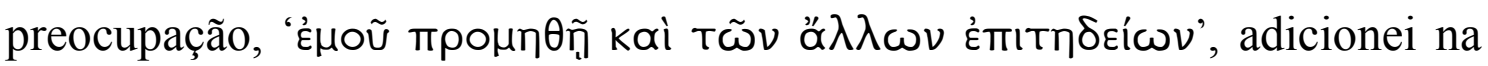
tradução o adjetivo 'receoso', formando uma nova perífrase, para dar conta do motivo da preocupação ou receio, introduzido pela conjunção $\mu$ ń.

${ }^{76}$ (44e3)oi oukoqóvтðı - Na Atenas democrática dos séculos V e IV não existia a figura do promotor público, que, modernamente, é quem acusa alguém em nome do Estado. Tal função podia ser exercida por qualquer cidadão. Os sicofantas eram tidos como informantes ou delatores, que obtiam dinheiro ora ameaçando denunciar alguém por qualquer delito, ora cobrando para não denunciá-lo.

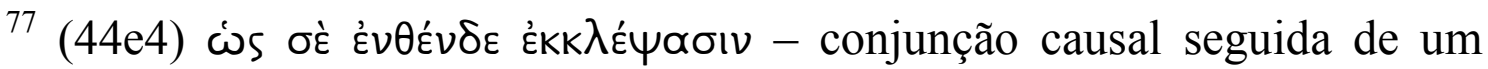
particípio (ver nota 44b10): 'alegando que o subtraímos daqui'.

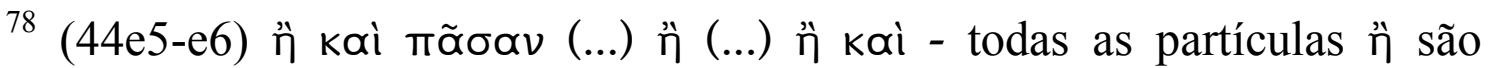

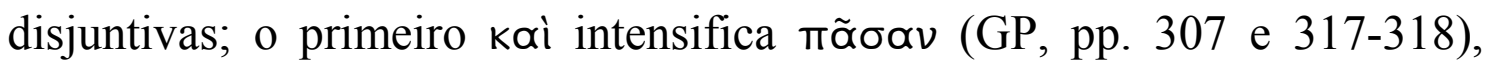
'inteira', 'toda', o segundo é uma advérbio, marcando o clímax do que foi enumerado (GP. pp.293), 'inclusive'.

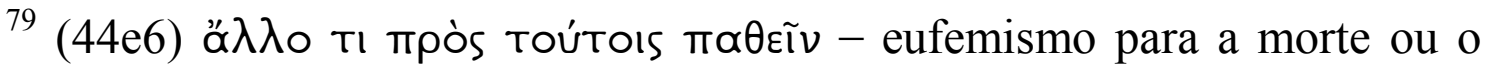
exílio (PLATO, 1997a, pp. 33).

${ }^{80}$ (44e6) Yá $\rho$ - dá as razões, de modo braquiológico, para Críton ter dito o que acabou de dizer (GP, pp. 60). Muitas vezes pode ser deixado sem tradução: 'Pergunto isso porque', 'Porque ...'.

${ }^{81}$ (45a1) Éaбov aủTò Xaípєıv - expressão idiomática (PLATO, 1979, pp. 261): 'esqueça isso!', 'deixe isso'.

${ }^{82}$ (45a1) yó 
${ }^{83}$ (45a3) $\dot{\alpha} \lambda \lambda \grave{\alpha}$ - Utilizado em comandos e exortações como um meio de combater a relutância ou indecisão de uma outra pessoa (GP, pp. 13-14): 'Vamos ...', 'Pois bem ....'.

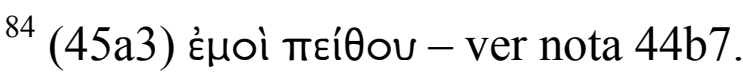

${ }^{85}$ (45a6) toívuv - Ver nota 44a5. Críton provavelmente imagina que Sócrates tem as mesmas preocupações que ele: 'então'.

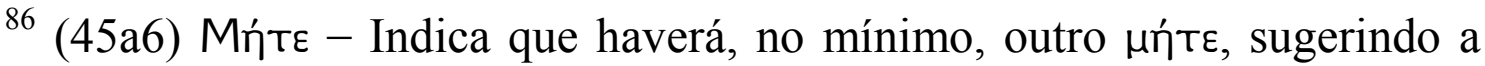
tradução 'nem ... nem'. Isso, no entanto, ocorrerá somente em 45b6, pois

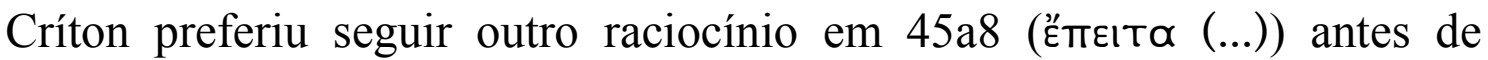
retomar a construção inicial em $45 \mathrm{~b} 6$.

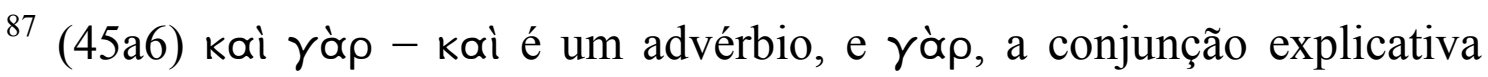
(GG, sec. 2815): 'pois, de fato,'.

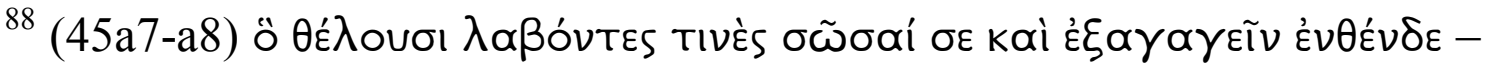
Construção de difícil interpretação e que, curiosamente, não é quase citada pelos comentadores. Dyer considera que ö é o objeto direto de $\lambda \propto \beta$ óvtes (PLATO, 1998, pp. 120) - os dois infinitivos seriam dependentes de

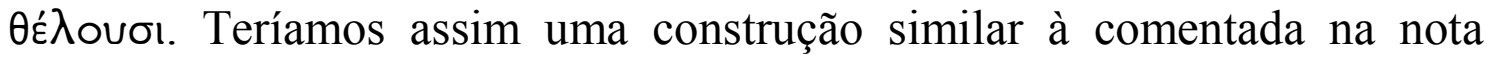
43c9-d1 - o pronome relativo exercendo uma função sintática em uma oração que, por sua vez, está subordinada à outra. Burnet, por sua vez, sugere, sem maiores explicações, que o trecho seja traduzido dessa forma: "which certain people are willing to take to save you ..." (PLATO, 1979,

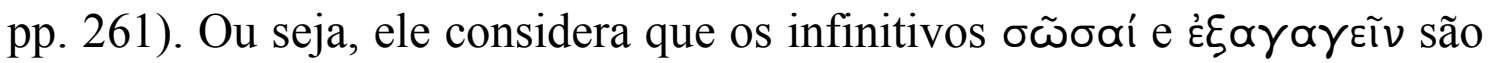
orações finais dependentes de $\lambda \propto \beta$ óvtєs, o que seria uma construção comum para os verbos que significam 'dar', 'tomar' ou 'receber' (GG, sec.

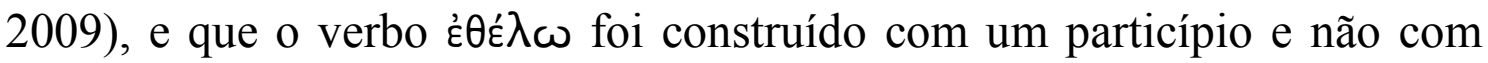
um infinitivo, uma possibilidade que não é mencionada por nenhum dicionário ou gramática listados na bibliografia deste trabalho. 
Quanto aos tradutores, Campos parece ter seguido a indicação de Burnet - "não é muita a prata que alguns querem obter para salvá-lo e retirá-lo daqui" (PLATÃO, 2008, pp. 118); Fowler, a de Dyer, fazendo algumas adaptações - "It is not a large sum of money we should pay to some man who are willing to save you ..." (PLATO, 2001b, pp. 157); por último, Croiset também parece ter seguido Dyer, mas preferiu uma construção completamente diferente, embora mantivesse o sentido geral do trecho -“C'est pour une médiocre somme que certaines gens sont disposés à te sauver, à te tirer d'ici". Quanto a mim, também considerei mais consistente a posição de Dyer, mas diferentemente do que fiz no trecho 43c9-d1, não imitei a construção do grego na tradução, pois esta soaria demasiadamente artificial - "nem é muito o dinheiro após o recebimento do qual alguns se disporiam a salvá-lo e tirá-lo daqui" - preferindo adaptar o trecho, como fizeram Croiset e Fowler - "nem é muito o dinheiro que querem alguns homens que estão dispostos a salvá-lo e a tirá-lo daqui”.

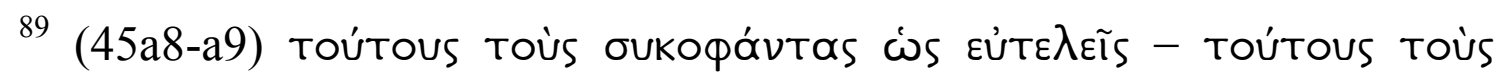
бUKoфávtas aparece como se fosse o objeto de ópã s, mas é, na verdade, o sujeito da oração introduzida por ćs (prolepse do sujeito).

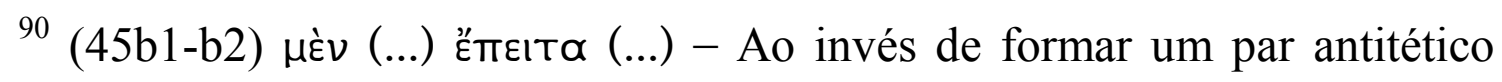

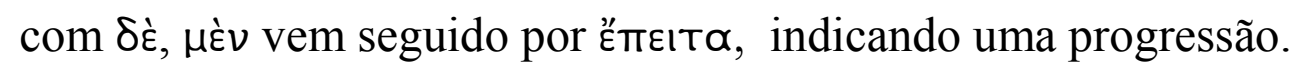

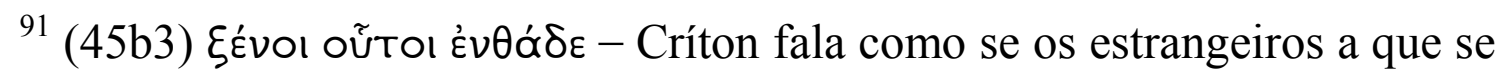
refere estivessem realmente diante dele, dado o pleonasmo que usou, pois

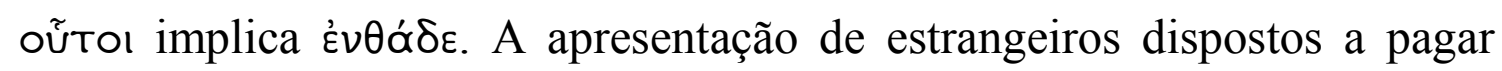
para libertar Sócrates é um bom argumento contra o seu possível temor quanto à reação dos sicofantas, pois, por serem estrangeiros, estariam livres a priori destes (PLATO, 1997a, pp.34). 


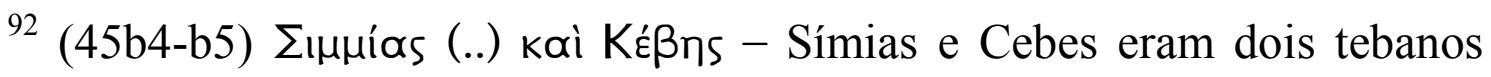
pitagóricos que desempenham um papel importante no Fédon, quando discutem com Sócrates acerca da imortalidade da alma.

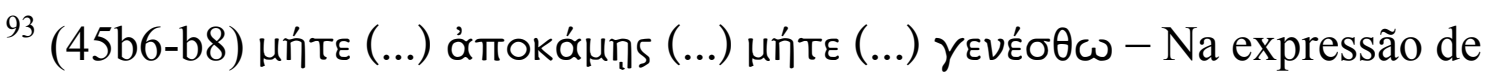
uma ordem negativa são usados tanto o subjuntivo aoristo (ámoká $\mu \eta \rrbracket s)$ quanto o imperativo aoristo ( $\gamma \varepsilon v \varepsilon ́ \sigma \theta \omega)$, este último restrito à terceira pessoa (BIZOS, pp. 139).

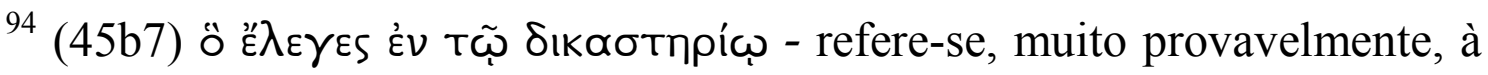
segunda parte de seu julgamento, quando, já declarado culpado, Sócrates deveria propor uma pena alternativa à morte. Discorrendo sobre a

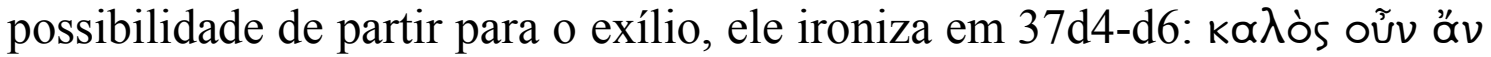

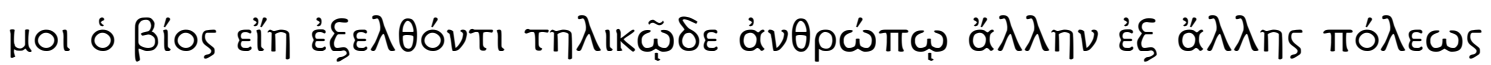

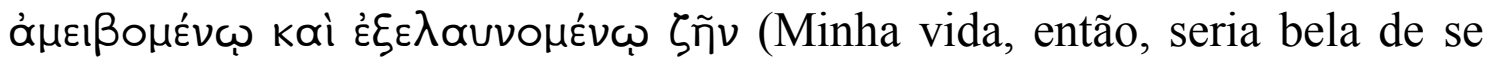
viver se, na minha idade, partisse para o exílio, mudando de uma cidade para outra e sendo continuamente banido).

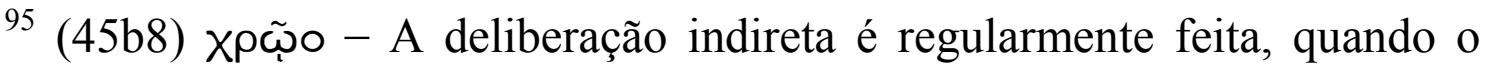
verbo da oração principal estiver em algum dos tempos primários, por meio do subjuntivo. O optativo foi usado nesse caso, muito provavelmente, porque o verbo da oração de que esta depende está no optativo (assimilação) (GG, sec. 2186 d)

${ }^{96}(45 \mathrm{c} 1)$ k đì tem a função de precisar o termo anterior, adequando-o à idéia que se deseja exprimir (HUMBERT, sec. 725). É melhor traduzida adverbialmente: 'ou melhor', 'precisamente'.

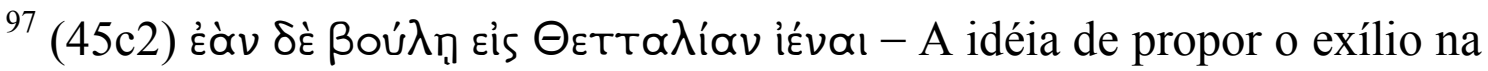
Tessália deve-se, muito provavelmente, como dissemos na nota 44b6, à interpretação literal que Críton fez do sonho narrado por Sócrates.

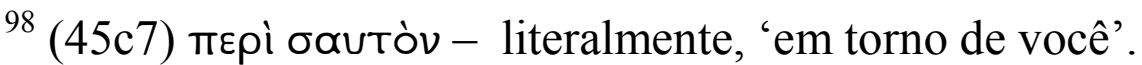


${ }^{99}$ (45d1) oüs = toútous ràp. Conforme nota em (46c2).

${ }^{100}$ (45d2) oixńon - 'partirá' - um eufemismo para a morte.

101 (45d2) Tò oòv uépos' - 'as far as is up to you' (IRWIN, pp. 46), 'dentro das suas possibilidades', 'tanto quanto lhe cabe', 'no que depende de você'.

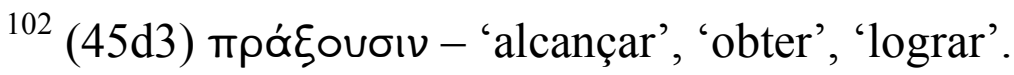

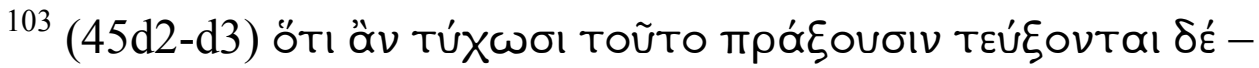

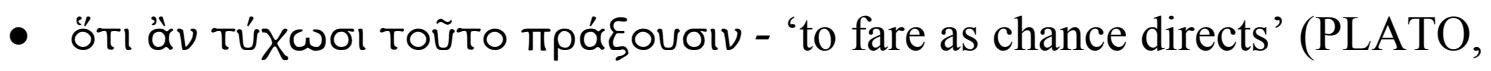
1997a, pp.37); 'to get along as chance directs' (PLATO, 1997b, pp. 36); 'to fare as best they may' (PLATO, 1979, pp. 265). Apesar destes

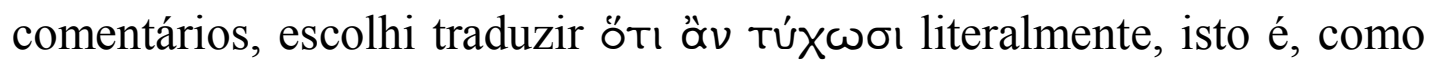
uma relativa, 'aquilo que obtiverem fortuitamente', porque o verbo

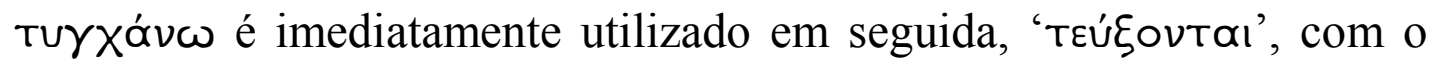
sentido claro de 'obter'.

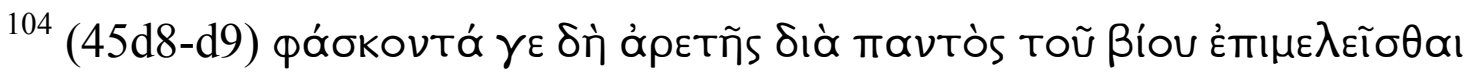

- фá́бKovtá - o particípio, em função atributiva, modifica o sujeito da

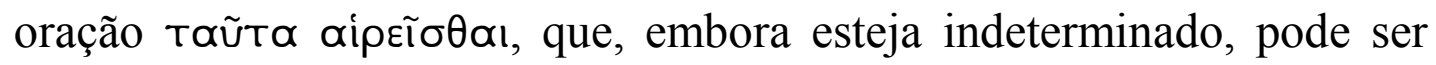
inferido como sendo Sócrates: 'você ... que vem afirmando'.

- $\gamma \varepsilon \delta \grave{~-~ a s ~ d u a s ~ p a r t i ́ c u l a s ~ c o m b i n a d a s ~ e n f a t i z a m ~ e ~ l i m i t a m ~ o ~ s e n t i d o ~ d e ~}$ фóokovtó (GP, pp. 245): 'você, ao menos, que vem afirmando incisivamente que ...'.

Sócrates realmente afirma isso em sua defesa, em Ap. 30a7-b4:

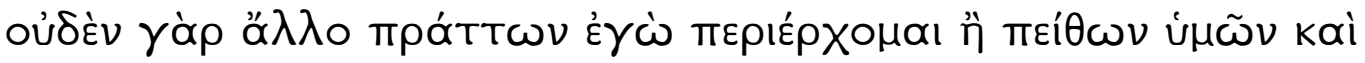

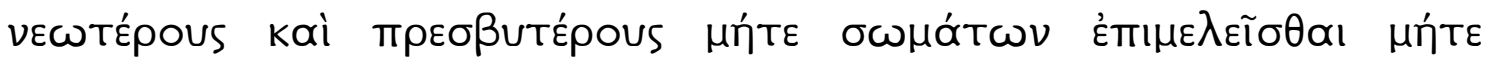

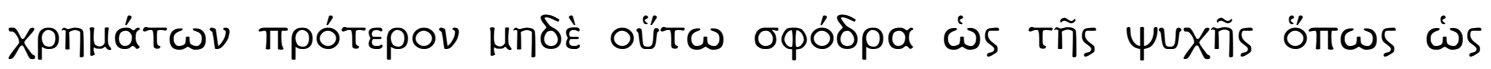

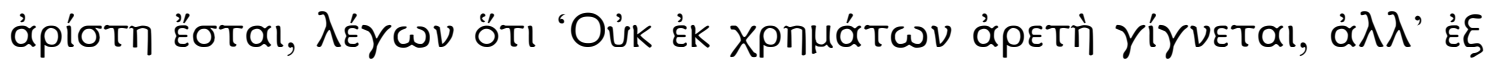

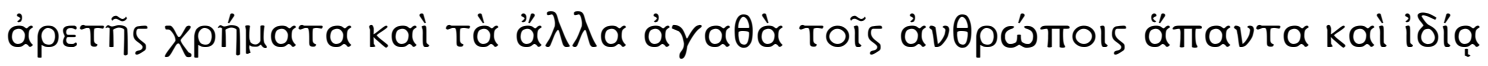

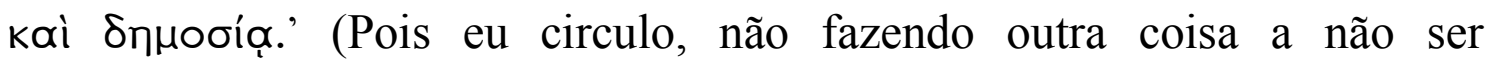


persuadindo-os, sejam jovens ou velhos, a não cuidarem antes do corpo ou do dinheiro tão seriamente como da alma, para que ela seja a melhor possível, dizendo que 'a virtude não vem do dinheiro, mas a partir da virtude o dinheiro e todas as demais coisas tornam-se boas para os homens, no âmbito público ou privado') - interpretei, seguindo Burnet, (PLATO,

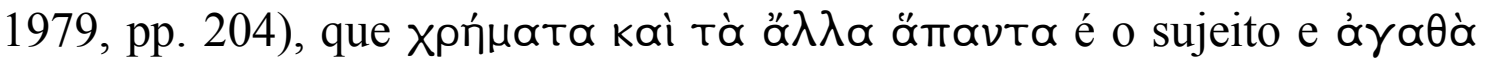

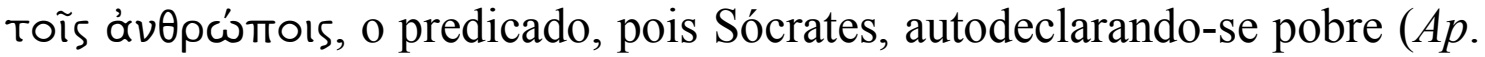
23b9), não poderia recomendar a busca pela ápetì como um bom investimento. O tom sarcástico da fala de Críton coloca-o, no entanto, diante de uma leitura mais atenta, como vítima de uma ironia de Platão, pois será precisamente por cuidar da virtude durante toda a vida que Sócrates se recusará a fugir da prisão.

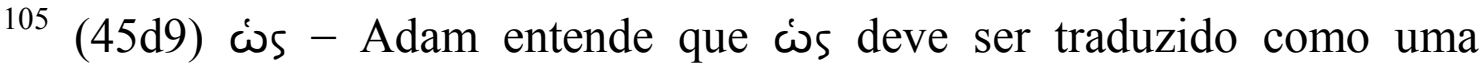
conjunção explicativa, como se se tratasse de um yà p da nota 44e6. Na sua opinião, portanto, Críton está praticamente dando uma ordem a Sócrates

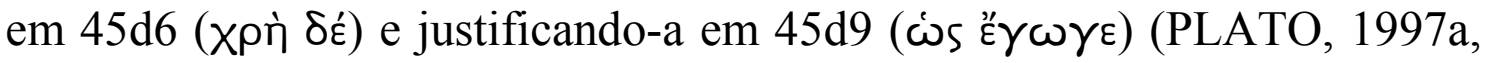
pp. 37).

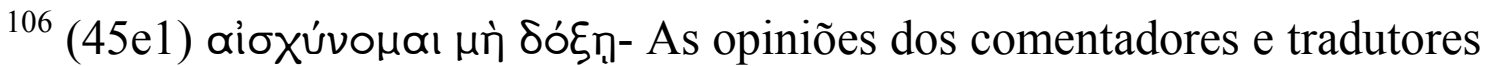
dividem-se quanto à interpretação deste trecho. Adam e Burnet consideram

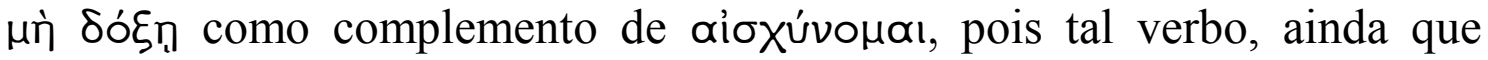
raramente (GG, sec. 2224a), admite esta construção, que é típica dos verbos que expressam temor [(PLATO, 1997a, pp. 38-39) \& (PLATO, 1979, pp. 265-266)]: 'eu me envergonho de que julguem ..,'. Dyer, Fowler e Croiset [(PLATO, 1998, pp. 122-123), (PLATO, 2001b, pp. 159-161) \& (PLATON, 2002, pp. 220)], por outro lado, consideram que aioxúvouðı é

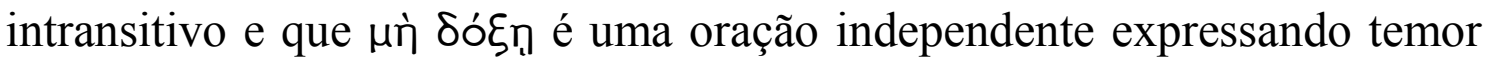
ou apreensão (GG, sec 1801): 'eu me envergonho (...), e temo que julguem 
que (...)'. Optei, na tradução, pela segunda interpretação, porque é a única que comunica em português a idéia de temor ou apreensão que, no grego, estaria presente, com maior ou menor ênfase, em ambas as construções. ${ }^{107}$ (45e1-46a1) äா

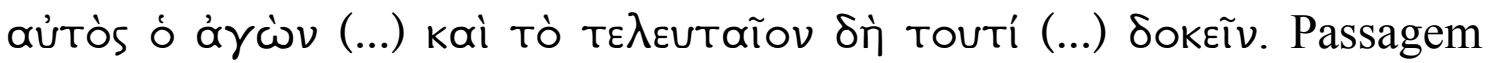
difícil e com múltiplas interpretações.

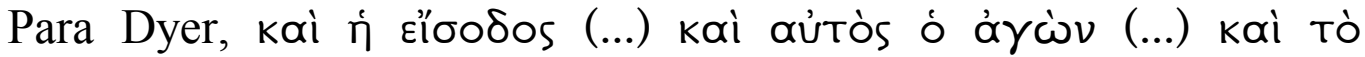

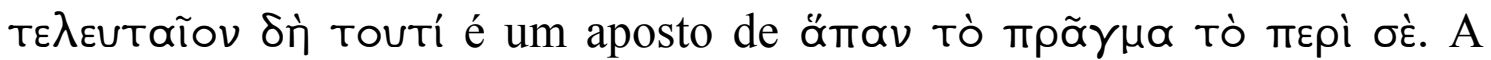
oração introduzida por ठокEĨv marcaria, por meio de um anacoluto, o retorno de Críton à idéia que vinha desenvolvendo anteriormente na oração

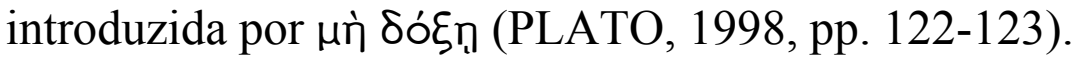

Watt (PLATO, 1927, pp.43) e Adam (PLATO, 1997a, pp.38-39) discordam da interpretação de Dyer no que se refere à função de Sokeĩv:

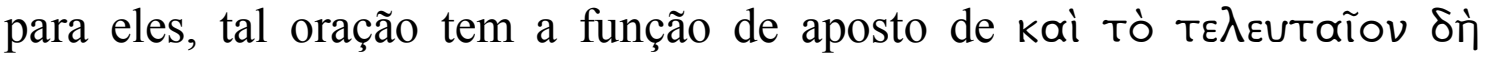
тoutí (GG, sec. 1987).

Por fim, Burnet (PLATO, 1979, pp. 265-267) considera que a oração

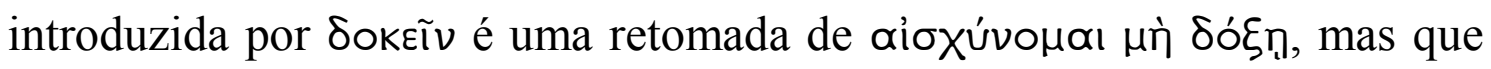
não constitui um anacoluto, devendo ser tratada como infinitivo exclamativo (GG, sec. 2115), exprimindo uma indignação.

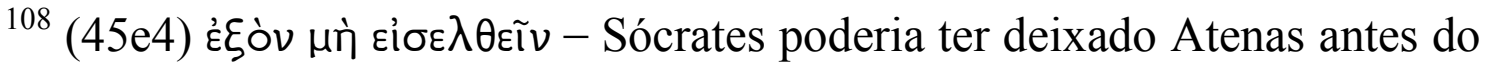
julgamento, o que provavelmente teria satisfeito Ânito (PLATO, 1979, pp. 266).

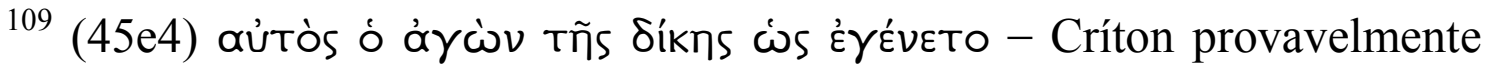
refere-se ao modo jocoso com que Sócrates se defendeu, principalmente quando poderia ter proposto, durante seu julgamento, uma pena alternativa à pena de morte (Ap. 35e1-38c4). 


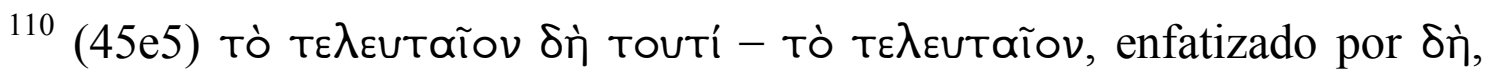
pode ser traduzido adverbialmente (PLATO, 1979, pp. 265-267); тoutí sugere que Críton aponta para a própria situação em que Sócrates se encontra (PLATO, 1997a, pp.38-39), porém seu sentido é indefinido: pode referir-se tanto ao resultado do julgamento, à sentença de morte, quanto a esta última oportunidade para revertê-la, na visão de Críton: 'no fim, essa cena aqui!'.

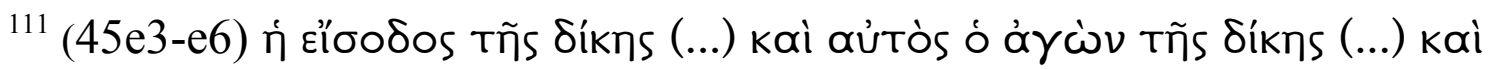

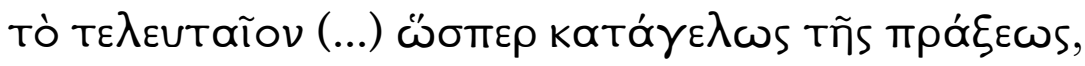

Adam nota que o vocabulário utilizado por Críton sugere uma comparação entre o julgamento de Sócrates e uma peça de teatro. A peça

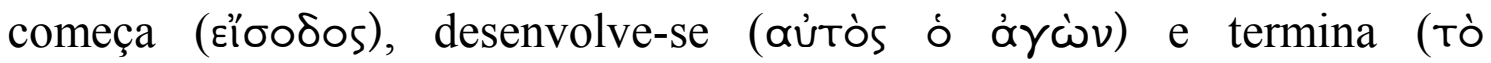

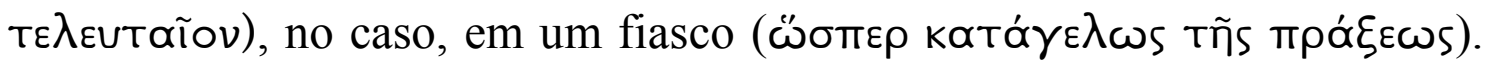

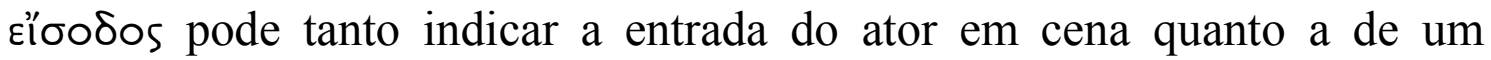
processo no tribunal; áyc่v pode ser tanto a atuação quanto a apelação (PLATO, 1997a, pp. 38). Burnet, no entanto, acha que a interpretação é despropositada, pois acredita que Críton seria incapaz de comparar o julgamento a uma comédia (PLATO, 1979, pp.265). Sem entrar no mérito acerca de quais seriam as reais intenções de Críton, o fato é que, para o leitor, tal comparação é sugerida e, portanto, deve manifestar-se na tradução.

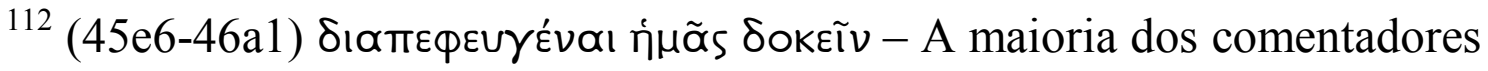
- uma importante exceção é Croiset (PLATON, 2002, pp. 220) - considera

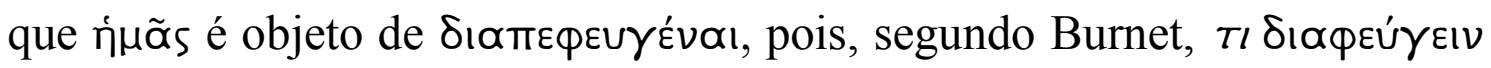
TIVó, com o sentido de 'alguém deixar de se lembrar de algo', é uma construção metafórica comum trazida do vocabulário usado na caça 
(PLATO, 1979, pp. 266). O sujeito de uma oração infinitiva é comumente omitido caso seja o sujeito ou o objeto da oração de que ela depende, caso já tenha aparecido em outra parte da sentença (GG, sec.1972) ou seja indefinido ou de caráter geral (GG, sec. 1980). Para Adam (PLATO,

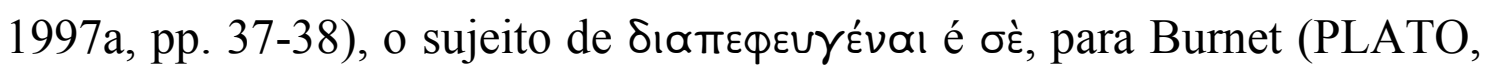
1979, pp.265), tò пра̃) $\mu \alpha$. Considero, como Burnet, que o sujeito é tò

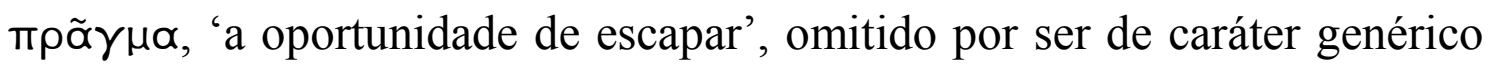
ou indefinido, mas sugerido por toutí, nota $45 \mathrm{e} 5$, isto é, não se trata do

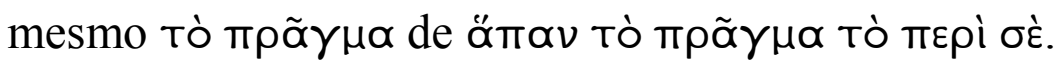

113 (46a1) olítıÉs - o pronome relativo introduz uma oração adverbial causal [(PLATO, 1979, pp. 267) e (GG, sec 2555)], sendo equivalente a

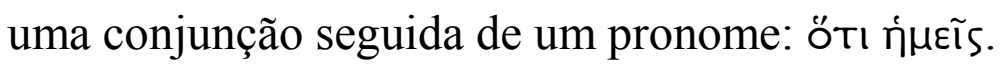

114 (46a2) oĩóv Tع ôv kaì Suvatòv - 'possível e factível'. Ocorre, a meu ver, uma gradação como em (46a7): oĩóv T $\varepsilon$ ôv marca a possibilidade em termos gerais de terem salvado Sócrates, enquanto que Suvatòv, a possibilidade prática de realizá-la. A diferença entre os dois termos poderia ser exemplificada deste modo: 'é possível 'oĩóv $\tau \varepsilon$ ' que eu corra $10 \mathrm{Km}$,

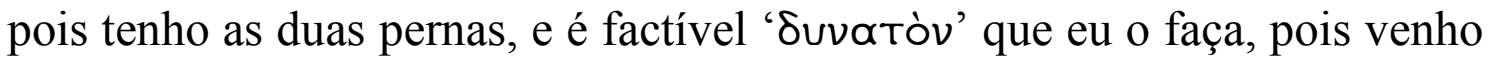
praticando corrida diariamente'.

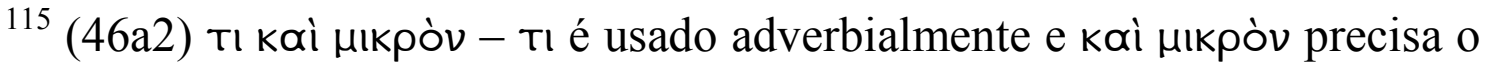
seu sentido (ver nota em $45 \mathrm{c} 1$ ), como se o corrigisse. Como o sentido de ambos os termos já é muito próximo, esta construção não foi imitada na tradução.

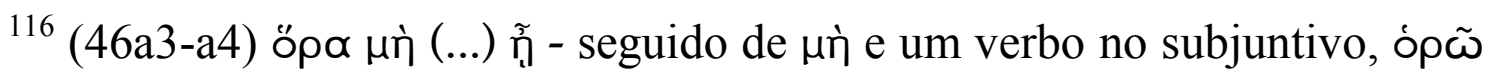
tem o sentido de 'cuide para que não (...)' (BIZOS, pp. 175).

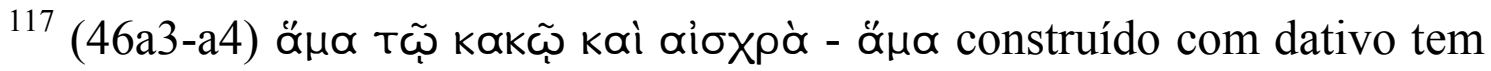
o sentido de 'juntamente com', 'além de' (GG, sec. 1701). 


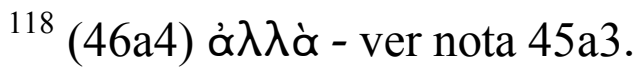

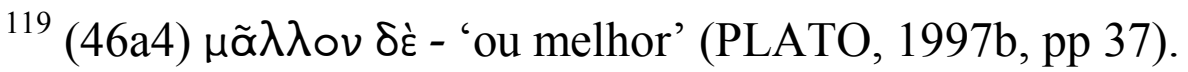

120 (46a6) Émıúons vUKTòs - ao colocar a noite que se aproxima como última possibilidade para a fuga de Sócrates, Críton está desconsiderando a evidência do sonho de Sócrates, que lhe daria mais uma noite ainda.

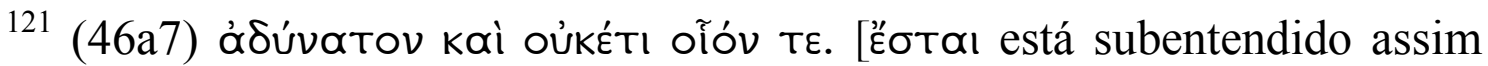

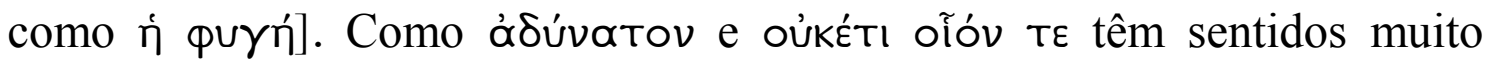
próximos (vide 46a2), muitos tradutores optam por traduzir somente oủkÉTI

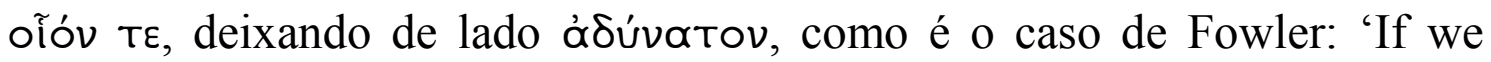
delay it can no longer be done.' (PLATO, 2001b, pp. 161). Porém, se notarmos que a 'falta de meios para fazer algo', a 'impotência' etc pertencem também ao campo semântico de ábúvatov, podemos considerar que as duas orações sugerem uma gradação semelhante mutatis mutandis à conseguida em (46a2): áoúvatov indicaria a impossibilidade em termos práticos de se empreender a fuga, enquanto que oúkétı oĩóv $\tau \varepsilon$, a impossibilidade em termos gerais de empreendê-la, funcionando quase como uma conseqüência do que foi dito na oração anterior.

122 (46a7) $\dot{\alpha} \lambda \lambda \grave{\alpha}$ - ver nota 45a3.

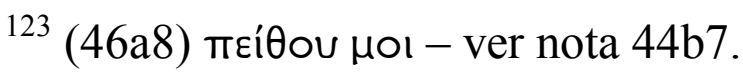

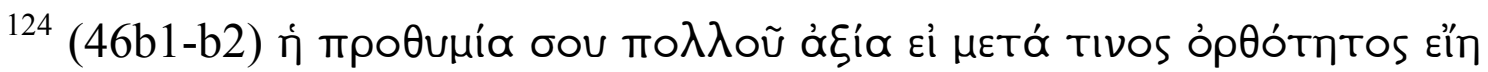
- Com a prótase formada com o optativo (Eln), era esperada uma apódose com o verbo no optativo modificado pela partícula åv. Nem o verbo nem a partícula estão presentes na apódose, e não é possível subentendê-los, já que ao menos a partícula é tida como obrigatória nesses casos. Deve-se tratar construção, portanto, como um anacoluto. É digno de nota (PLATO, 1997a, pp. 40), no entanto, que Sócrates ao utilizar eỉ - Eỉn (potencial), e não $\varepsilon i ̉$ - ก๊ (irreal), não está descartando a priori a possibilidade de mudar 
de idéia, isto é, de que a proposta de Críton seja de fato correta. Algo semelhante ocorreu na narração do seu sonho, como vimos na nota 44b1b3.

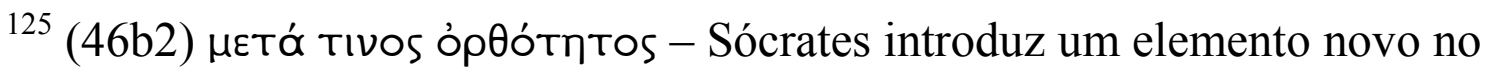
diálogo no que diz respeito à avaliação de um plano ou propósito: a sua correção. Isso contrapõe-se ao método proposto insistentemente por Críton

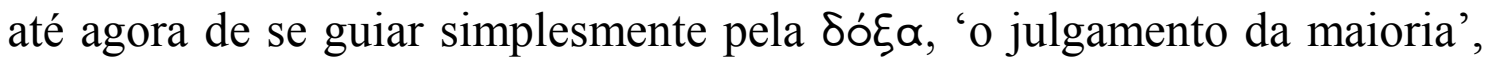
'a opinião comum'.

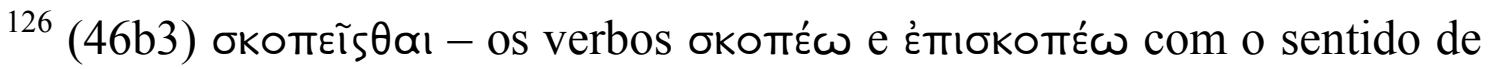
"examinar", “investigar" são praticamente sinônimos em Platão (ÉDOUARD des PLACES, pp. 201). Porém são usados somente no presente e no imperfeito e nas vozes ativa e média no dialeto ático no período que antecede Aristóteles (salvo em raríssimas ocasiões segundo o

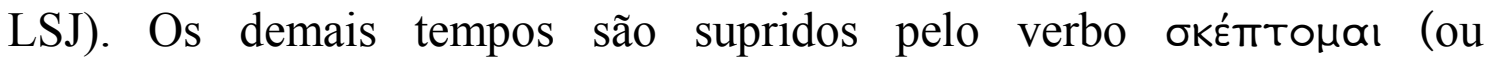

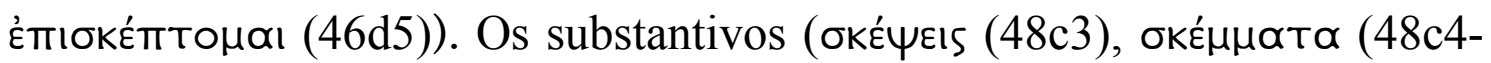

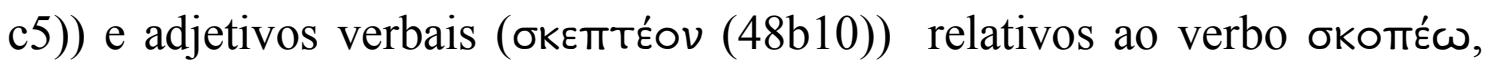

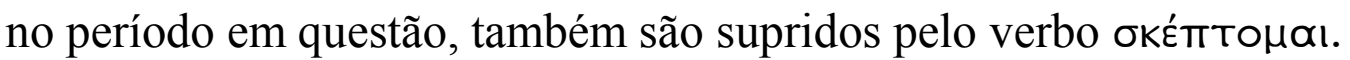

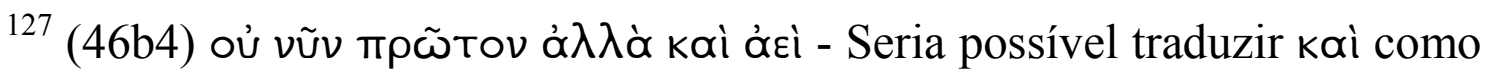

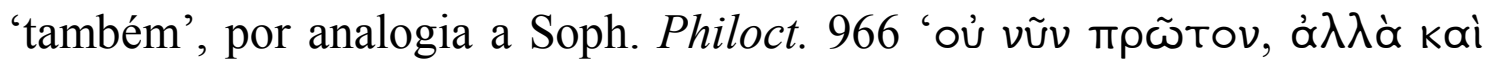

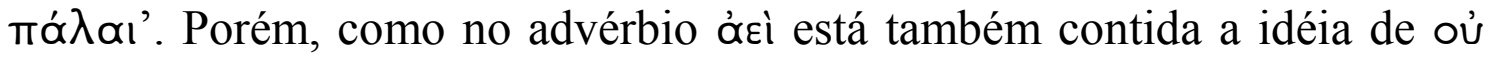

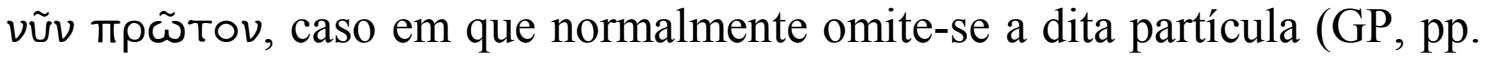
3), seria também possível considerar que kaì é utilizado enfaticamente (GP, pp. 317), significando 'de fato', 'na verdade'.

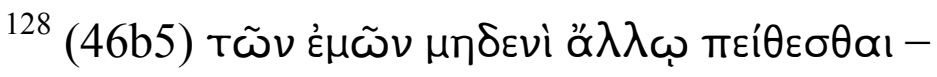

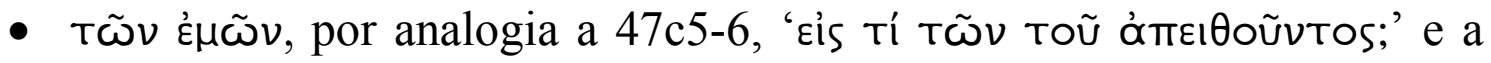

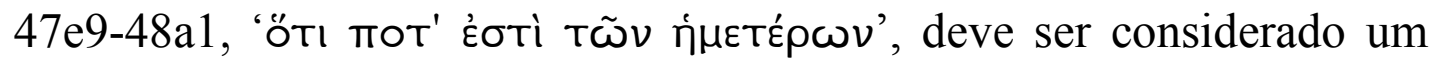
neutro plural, referindo-se, como sugere Burnet, à alma com seus 
sentimentos e pensamentos assim como ao corpo e às suas particularidades (PLATO, 1979, pp. 268). A expressão é muito difícil de ser traduzida, porém não considero que ela possa ser ignorada, como fizeram Fowler e Croiset em suas traduções, respectivamente, em (PLATO, 2001b, pp. 161), 'a man who folows nothing but ...', e (PLATON, 2002, pp. 220), 'de ne me laisser persuader par rien que ...', pois de acordo com a Apologia, Sócrates considerava que também deveria obedecer a (ou deixar-se persuadir por) alguém que fosse

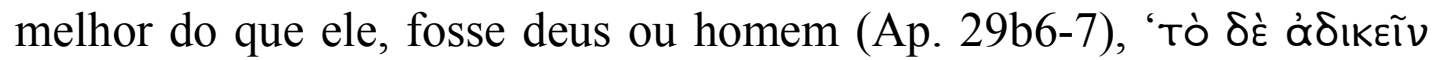

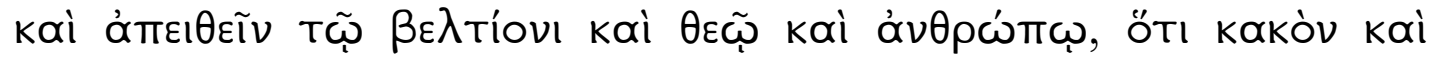

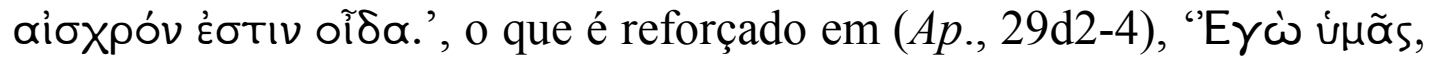

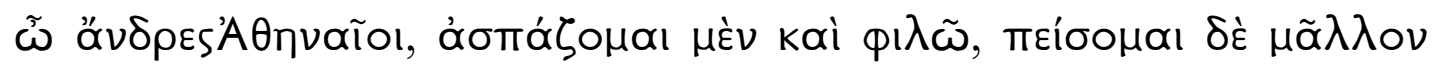

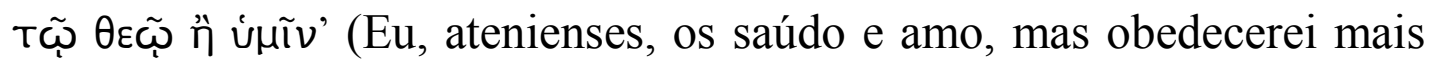

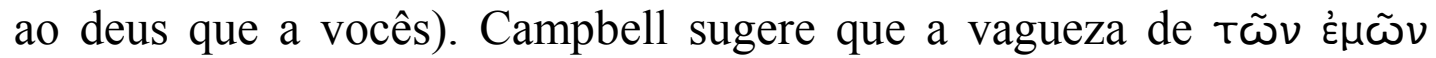
$\mu \eta \delta \varepsilon v i$ ơ $\lambda \lambda \omega$ poderia ser reproduzida por algo como "nothing else in my command' (PLATO, 1997b, pp. 39), o que considerei uma boa sugestão, já que englobaria as considerações de Burnet e não eliminaria os outros casos em que Sócrates aceitaria submeter-se, mesmo que não soubesse, não compreendesse as suas razões ou não concordasse com estas. Ver também nota $44 \mathrm{~b} 7$.

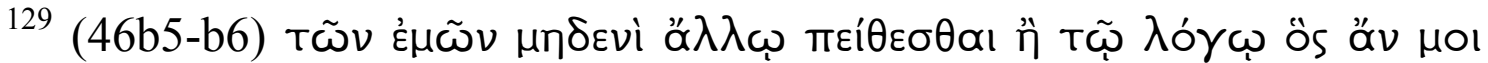

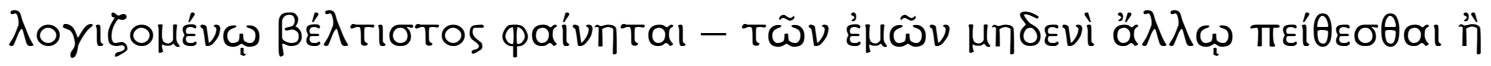

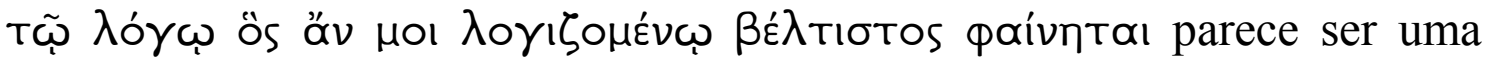

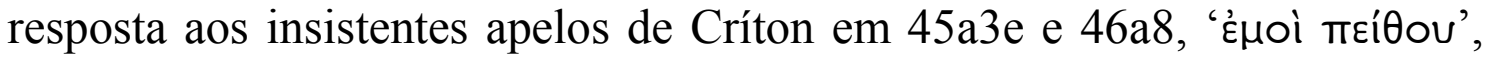
para que Sócrates se deixasse persuadir por um outro tipo de argumentação. Stokes notou que este tipo de argumentação usado por Críton, a tentativa de chamar um personagem, decidido a praticar um ato considerado pelo senso 
comum como insano, "à razão" por meio do uso reiterado do verbo $\pi \varepsilon i ́ \theta \omega$ na voz média, principalmente no imperativo, era comum nas tragédias de Sófocles, conforme os exemplos colhidos por Bernard Knox (KNOX, pp. 13-14). O desenvolvimento do diálogo, até pelo menos este ponto, deveria parecer, portanto, bastante familiar aos seus primeiros leitores (STOKES, pp. 39).

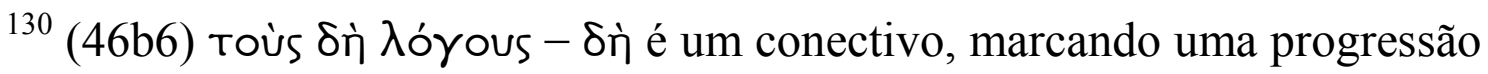
nos argumentos (GP, pp. 238-239). Pode ser traduzido adverbialmente por 'assim', 'por isso'.

${ }^{131}$ (46b8) $\dot{\alpha} \lambda \lambda \grave{\alpha}$ - conjunção adversativa marcando uma oposição extrema entre as duas orações (GP, pp. 1): 'pelo contrário'.

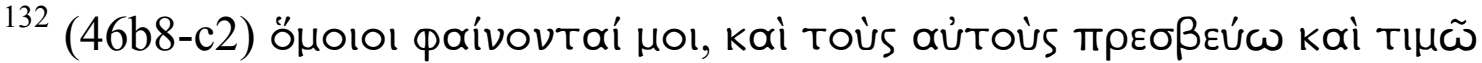

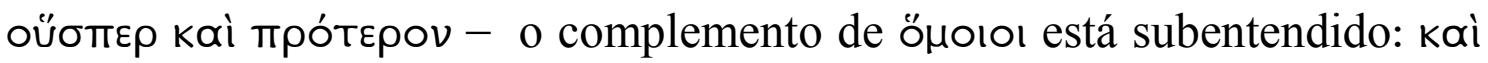

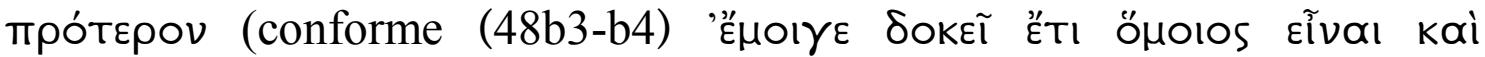

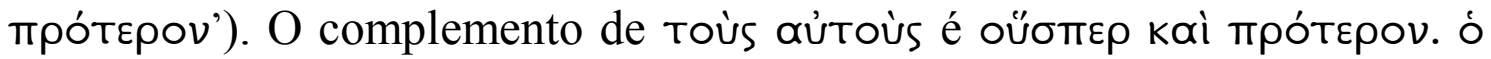
aútós, assim como adjetivos e advérbios que denotam similaridade ou dissimilaridade, constroem-se tanto com um dativo quanto com kaì ou com о̆бтєр (GG, sec. 1501a).

${ }^{133}$ (46c2) $)^{\tau} \nu$ - introduz uma oração relativa que é, na prática, equivalente

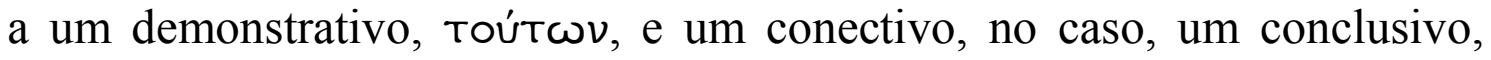

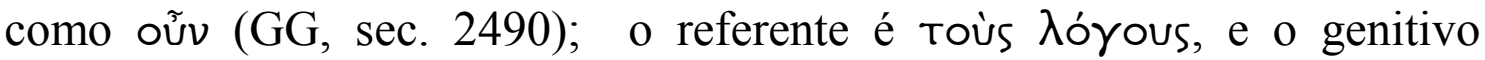
explica-se por se tratar do segundo termo de uma comparação: 'Então (...) do que estes (...)'.

${ }^{134}$ (46c2) $\beta \varepsilon \lambda T i ́ \omega=\beta \varepsilon \lambda T i ́ o v \alpha \lambda o ́ \gamma o v$.

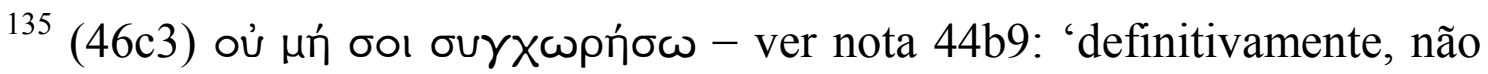
cederei a você'. 


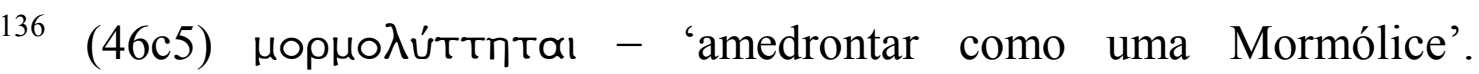
Mormólice era uma espécie de demônio aterrorizador com o qual se metia medo às crianças (GRIMAL, pp. 318-319). Utilizei o verbo inventado por Campos (PLATÃO, 2008) por entender, como ele, que seria a melhor forma de traduzir o verbo grego em questão.

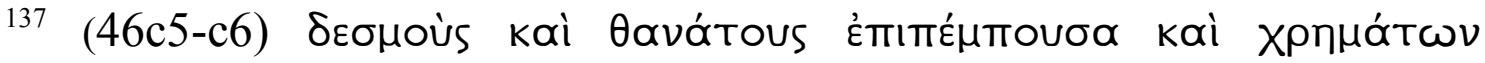
å

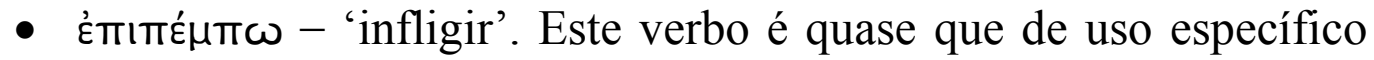
dos deuses em contextos que marcam suas 'visitações'. Sócrates, utilizando-o aqui, muito provavelmente está sugerindo que o

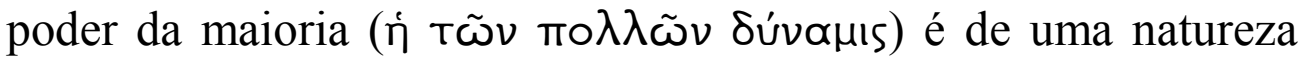
sobrenatural e misteriosa, algo já iniciado quando utilizou o verbo

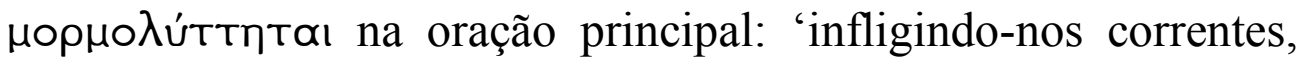
mortes e confisco de dinheiro'.

${ }^{138}$ (46c7) бкотоі́ $\varepsilon \theta \alpha$ - ver nota em $46 b 3$.

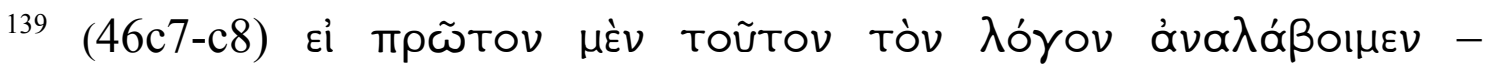
Condicional com apódose suprimida, mas que pode ser subentendida (ã

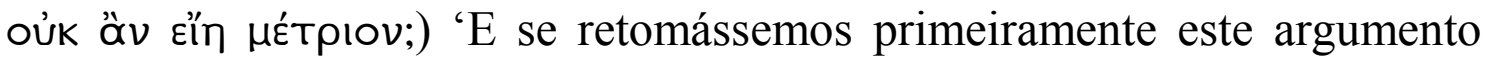
que você fala acerca dos juízos?'.

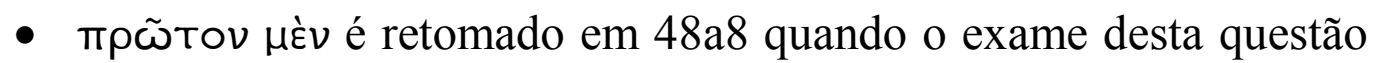
termina. No entanto, quando passa para outro ponto, Sócrates faz

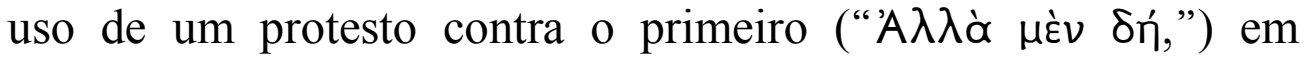

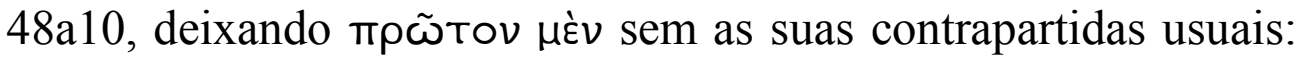

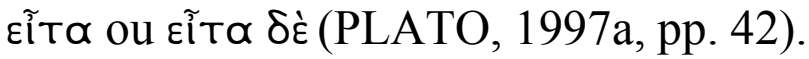

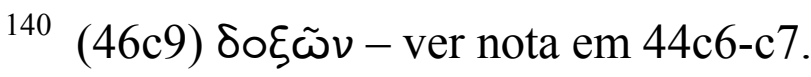

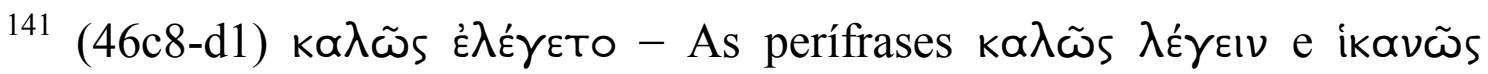
$\lambda \varepsilon ́ \gamma \varepsilon ı \nu$ são expressões idiomáticas usadas por Platão neste diálogo 
significando 'dizer com senso', 'argumentar com critério', 'falar bem',

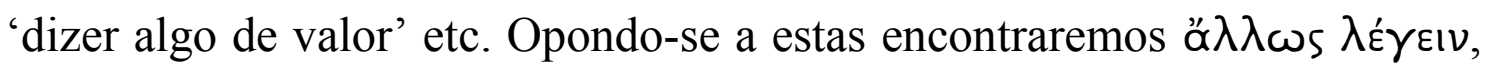

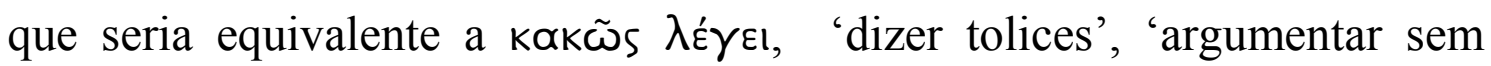
critério', 'palavrear' etc. Dentro desse mesmo campo semântico encontraremos também a perífrase tì $\lambda \varepsilon ́ \gamma \varepsilon ı \nu$, 'dizer algo sensato', que se

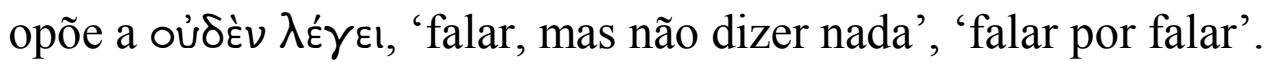

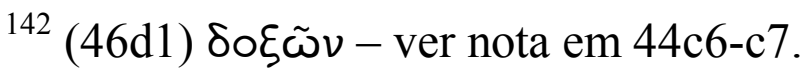

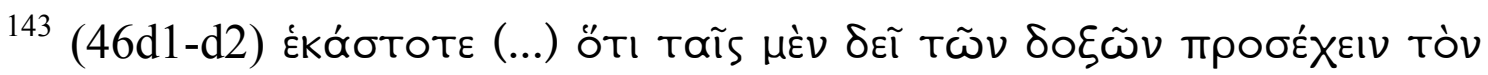
voũv, Taĩs $\delta \dot{~ o u ̈ ; ~}$

- Éкáotote - indica que Sócrates e Críton já debateram este assunto anteriormente.

- Emlyn-Jones conjectura que a pergunta de Sócrates seria uma resposta a idéia de que todos os juízos teriam o mesmo peso, cuja origem é

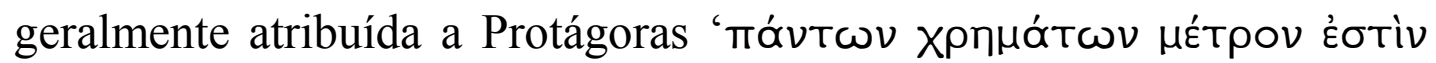

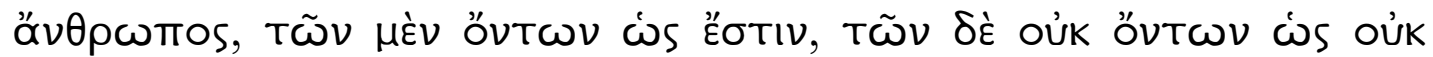
ह้otıV' ('O homem é a medida de todas as coisas, das que são porque são, das que não são porque não são') (PLATO, 2001a, pp. 62).

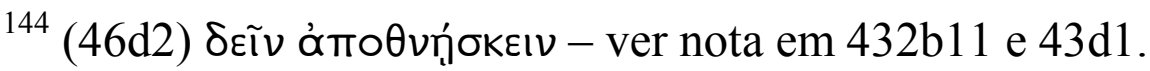

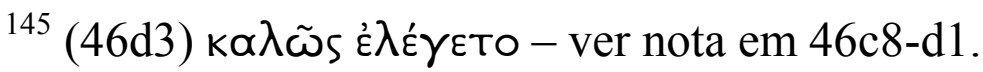

${ }^{146}$ (46d3) äpa - conectivo usado para denotar uma sucessão de eventos, mas expressando que, nesse em particular, algo surpreendente foi percebido durante a sua ocorrência (GP, pp. 35-36): 'depois de tudo que ocorreu'.

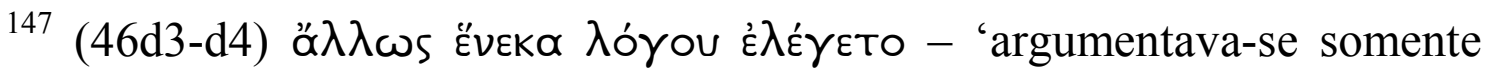
por argumentar' - ver nota em 46c8-d1.

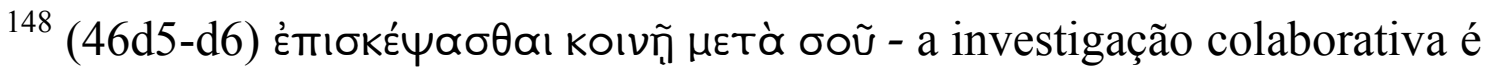
tipicamente socrática: é essencial que todos fossem unânimes com relação 
a todos os argumentos para que as conclusões extraídas deles fossem

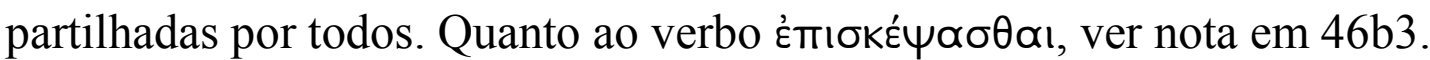

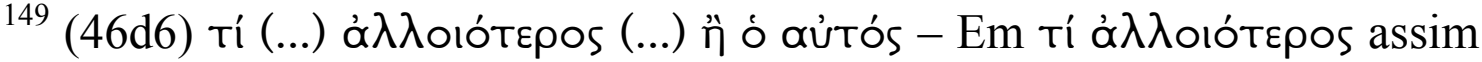

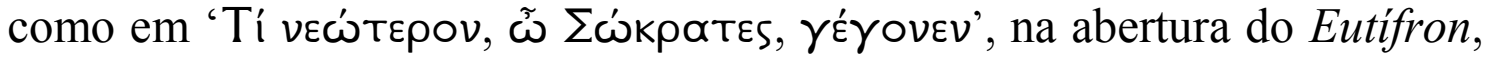
Euthphr., 2a1, o comparativo deixa a segunda parte da comparação subentendida (GG, sec.1082a): 'algo diferente do anterior'. Tí

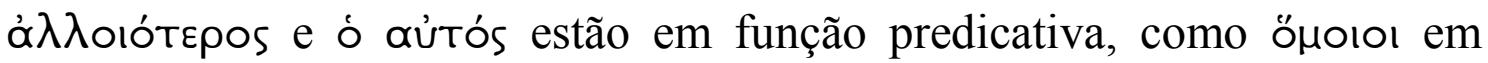
46b8-c1. O sujeito, extraído do contexto, é o argumento de que alguns juízos são bons, mas outros não.

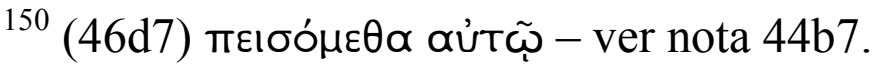

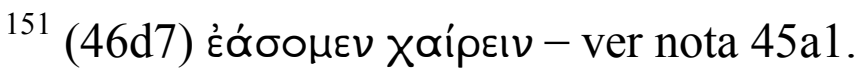

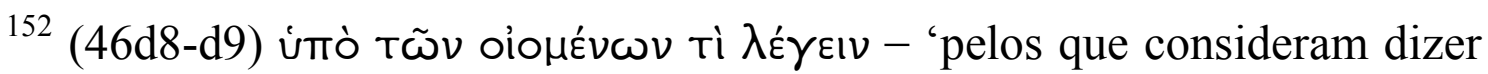

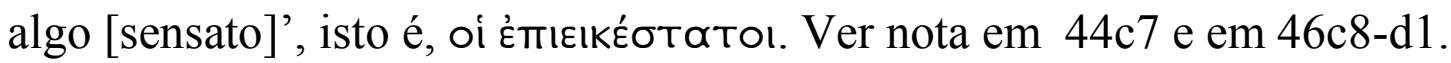
${ }^{153}$ (46d8) $\pi \omega_{\varsigma}(. ..) \omega^{\tau} \delta \varepsilon$ - 'mais ou menos assim'.

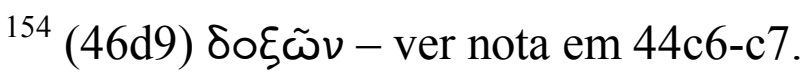

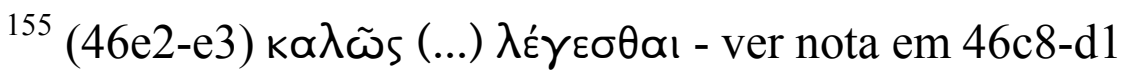

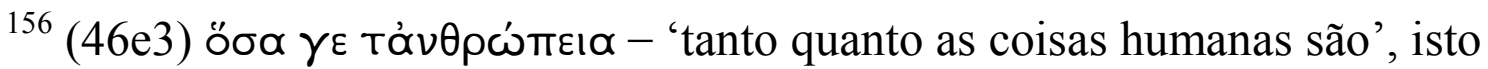
é, 'tanto quanto alguém pode prever, dada a sua condição humana' (PLATO, 1997b, pp. 40).

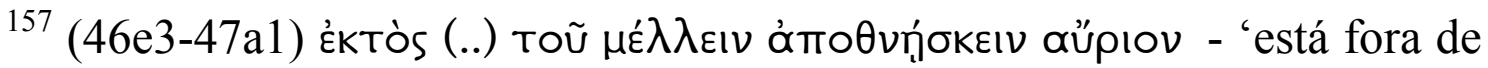
cogitação que você morra amanhã'. aủpıov pode ser considerado um lapso de Sócrates, já que, como vimos, ele acredita que morrerá no terceiro dia; pode ser também uma brincadeira dele com Críton, contrastando a sua calma, mesmo com a morte iminente em vista, com o nervosismo do amigo (PLATO, 2001a, pp. 63); ou, simplesmente, uma concessão de Sócrates a Críton, que não queria discordar do amigo em um ponto insignificante como este (PLATO, 1979, pp. 271). 


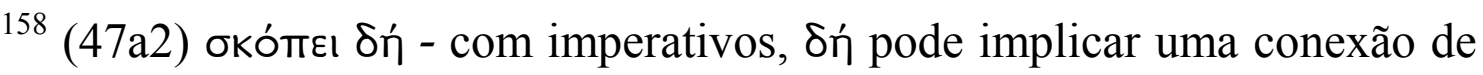
ordem lógica, como se o comando tivesse surgido naturalmente do que se falou anteriormente (GP, pp. 216-217): 'examine, então'. Quanto ao verbo бко́тєı, ver também nota em 46b3.

Sócrates inicia a partir de agora uma sessão de perguntas e respostas curtas com Críton, uma forma característica de argumentação que Platão utilizava nos diálogos ditos socráticos. Seu objetivo é fazer Críton concordar com o que, até agora, foi somente afirmado por Sócrates: nem todas as opiniões são dignas de consideração. Conseguir a aceitação sincera de Críton acerca desse pressuposto é vital para que Sócrates derrube mais adiante a posição inicial do amigo (PLATO, 2001a, pp. 63).

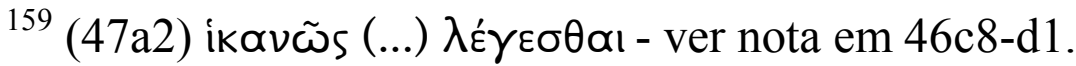

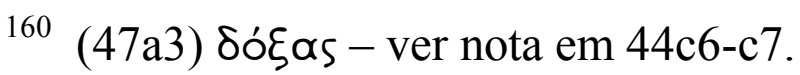

161 (47a6) K $\alpha \lambda \tilde{\omega} \varsigma$ - questões do tipo 'sim' ou 'não' são freqüentemente respondidas repetindo-se o verbo ou alguma outra palavra enfática com ou sem advérbios confirmatórios (GG, sec 2680 a-d).

162 (47a11) חஸ̃s $\delta$ ' oủ; - Pergunta que indica não somente o assentimento ao que foi proposto mas também que tal concordância era inevitável (GP, pp.176): 'Como não?'

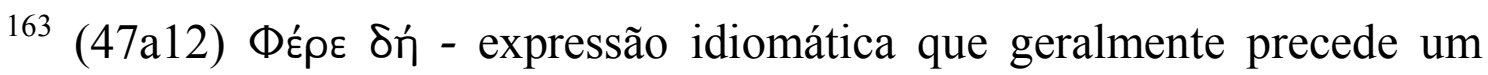
comando com o intuito de anunciá-lo simplesmente (GP, pp. 216-218). No contexto, podemos traduzi-la por 'Diga, então'

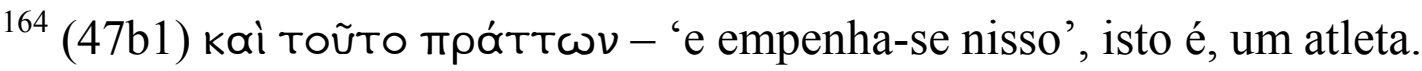

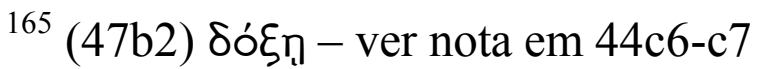

${ }^{166}$ (47b8) $\Delta \tilde{\eta} \lambda \propto \delta$ - - 'Evidentemente', 'Sem dúvida' (GP, pp. 205). Críton entra em evidente contradição com o que tinha dito em 44d1-d2 ( $A \lambda \lambda \lambda^{\prime}$

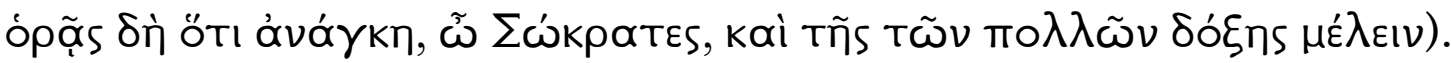




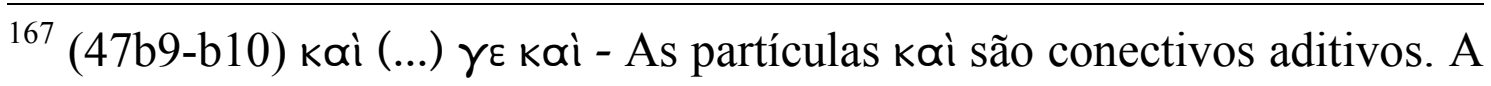
partícula $\gamma \varepsilon$ enfatiza a adição (GP, pp. 157-159): 'além de (...) e (...)'.

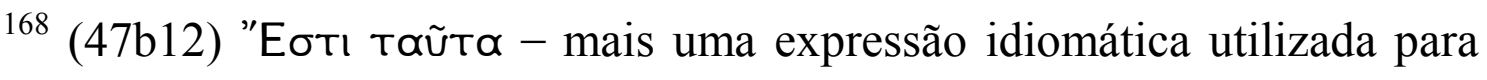
responder afirmativamente uma pergunta do tipo 'sim' ou não'. Ver nota em 47a6: 'É isso mesmo', 'É verdade'.

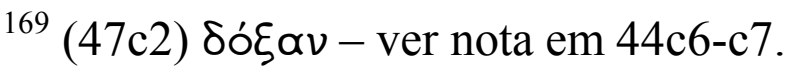

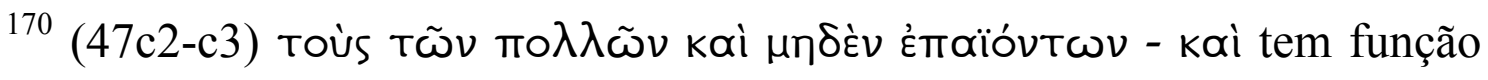
explicativa. Ver nota em $45 \mathrm{c} 1$.

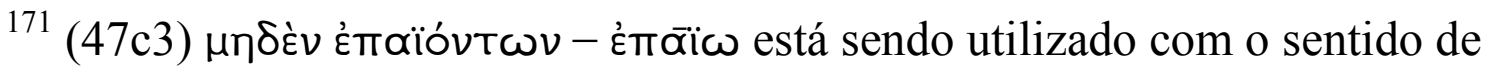
'ser especialista em alguma coisa'; $\mu \eta \delta \dot{e ̀ v}$ é um acusativo adverbial indicando, nesse caso, o grau de conhecimento ou especialidade que a maioria tem. Sócrates, ao preferir a forma $\mu \eta \delta \dot{\varepsilon ̀ v ~ a ~ o u ̉ \delta e ̀ v, ~ e s t a ́ ~ a f i r m a n d o ~}$ que este grau de conhecimento, 'nenhum', não se refere a nenhuma área do conhecimento em particular, sendo, portanto, uma negação generalizadora: 'dos que não conhecem absolutamente nada' (PLATO, 1997b, pp. 42).

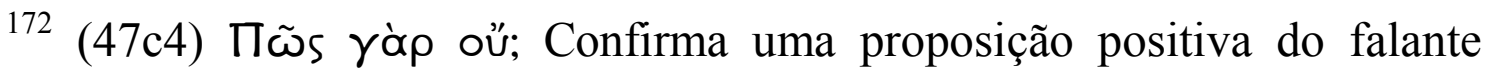
anterior (GP, pp. 86). 'Certamente sofrerá.'

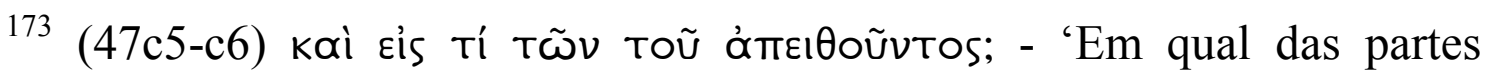
daquele que desobedece [ele age]?'

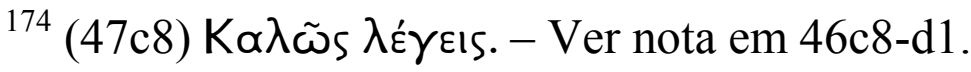

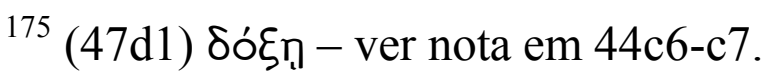

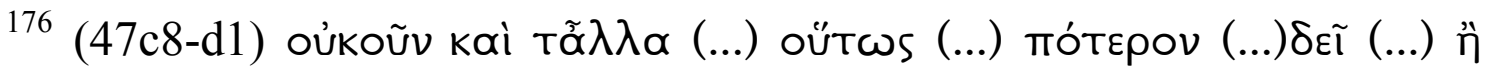
(...)Toùs ö $\lambda \lambda$ ous; - algumas edições do Críton costumam também inserir um ponto de interrogação (;) antes de mótєpov. A OCT, edição que seguimos, porém, entende que no ponto em questão há uma somente uma vírgula. Se concordarmos, no entanto, com o entendimento de Denniston sobre o uso de oưkoũv em orações interrogativas nos diálogos platônicos, 
concluiremos que o problema da pontuação posto acima é de pouca importância: "In Plato, as des Places well observes, the boundary between oúkoũv questions and oủkoũv statements cannot be rigidly drawn. There is probably always some tinge of interrogation in the tone: and it is significant that, as des Places points out, Plato uses oúkoũv in dialogue only, never in continuous discourse. (...) I should be inclined, in fact, to go further than des Places, and actually insert the question mark everywhere (...) The question of punctuation is, however of subordinate importance. What is important is that we should recognize the existence of an interrogative tinge, whether or not strong enough to call for a question-mark. In any case, des Places is certainly right in saying that the distinction between interrogative and affirmative cannot, in Plato, be made the basis of classification" (GP, pp. 433-434). Com este entendimento, resolvi quebrar a longa sentença em questão em diversas orações interrogativas, dando em cada uma delas, um sentido diferente para oúkoũv : de "ora", de tom mais interrogativo, a "assim", mais indutivo.

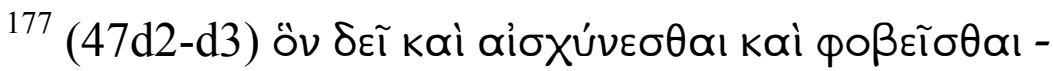

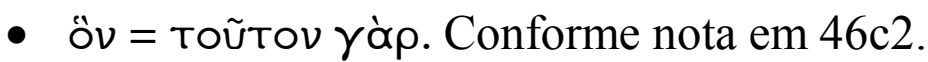

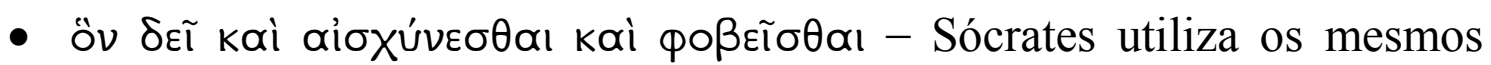
verbos que Críton utilizou em sua argumentação, respectivamente, em

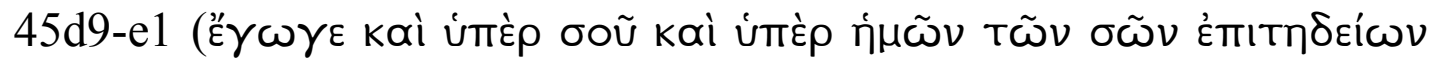

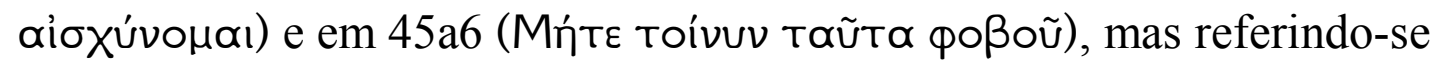
ao especialista, algo totalmente diverso do que Críton fez.

178 (47d3) ఢَ = kaì toút

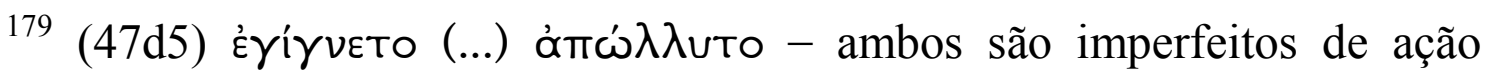
costumeira (GG, sec. 1893) e (PLATO, 1997a, pp. 49): 'como dizíamos, torna-se melhor com o justo, mas é destruído com o injusto'. 


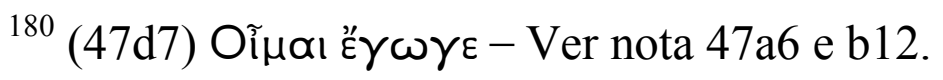

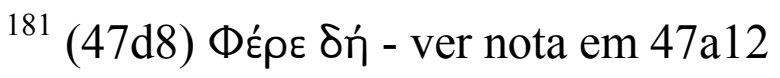

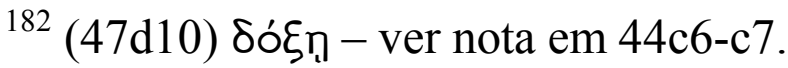

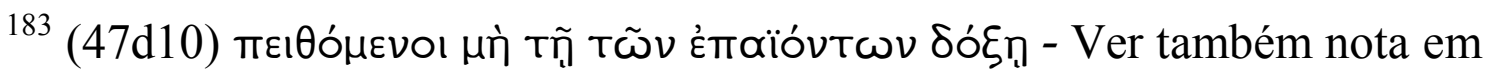
$44 \mathrm{~b} 7$.

${ }^{184}$ (47e1) Tou - expressa o grau de confiança ou certeza de quem pergunta acerca daquilo que pergunta (PLATO, 1997b, pp. 44): 'talvez', 'presumo' etc.

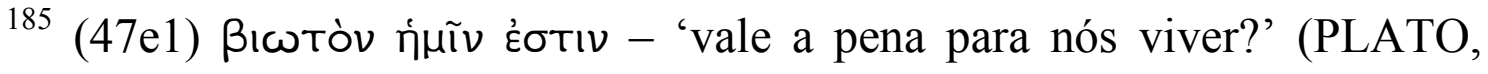
1979, pp. 273).

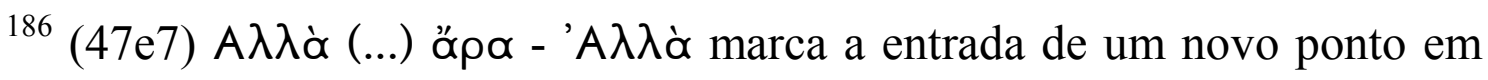
questão, enquanto que öpa conecta-o logicamente ao que estava sendo tratado (GP, pp. 42): 'Bem, então, (...)'.

${ }^{187}$ (48a3)'A $A \lambda \grave{\alpha}$ - Introduz uma questão implicando uma resposta oposta a um pensamento expresso ou implicado pelo falante anterior (GG, sec. 2654).

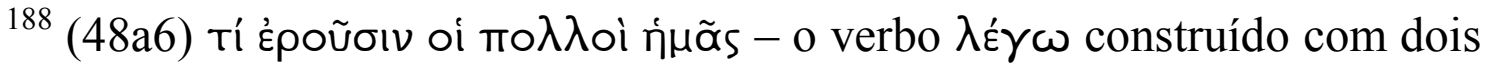
acusativos, um deles pessoal, significa 'dizer algo de alguém', e não ‘dizer algo a alguém', que exigiria um dativo pessoal ou o mesmo acusativo pessoal precedido da preposição mpós. Muitas traduções, no entanto, sem que nenhuma explicação seja dada, adotam esta última interpretação, errônea, a meu ver.

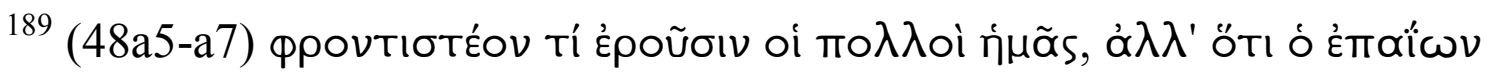

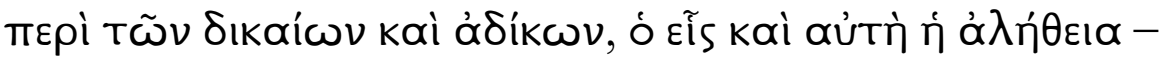

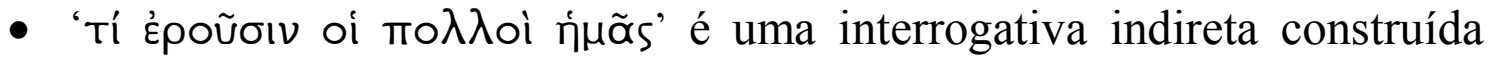
como se se tratasse de uma interrogação direta, isto é, de modo paratático. 'ó $\alpha \lambda{ }^{\prime}$ ötı (...)' é também uma interrogativa indireta, mas 
introduzida por um pronome relativo, isto é, construída como uma oração dependente.

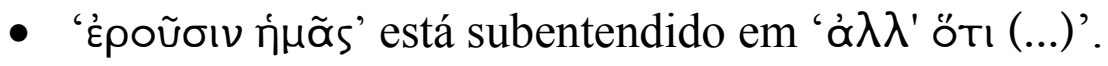

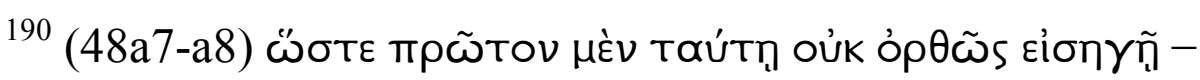

- ڤँбтє - Conjunção consecutiva, mas que podemos traduzir adverbialmente: 'Conseqüentemente'

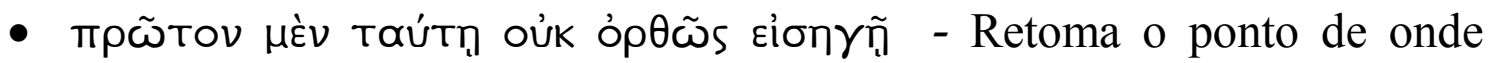

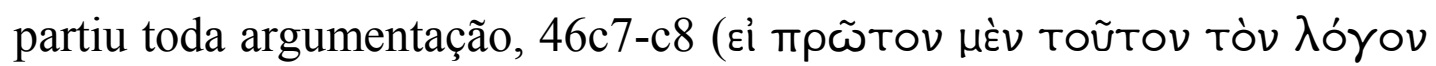

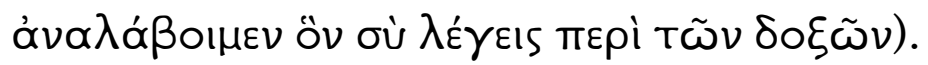

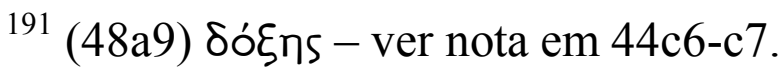

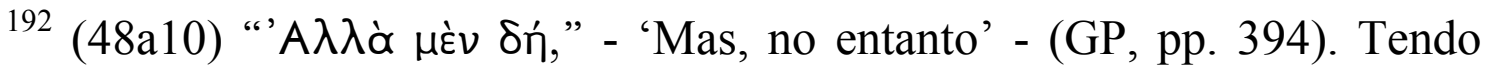
revalidado que o juízo da maioria não tem valor per se, Sócrates passa a analisar o segundo ponto, o poder da maioria, introduzido por Críton em

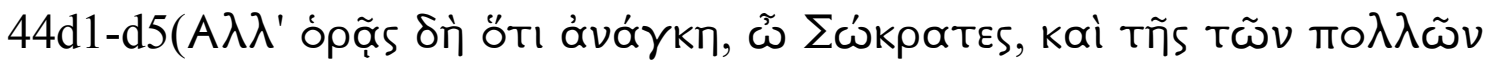

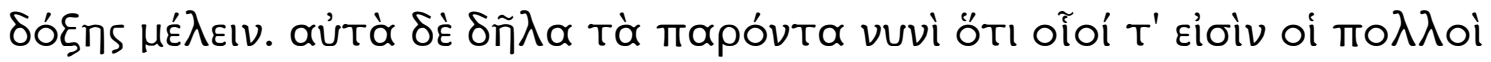

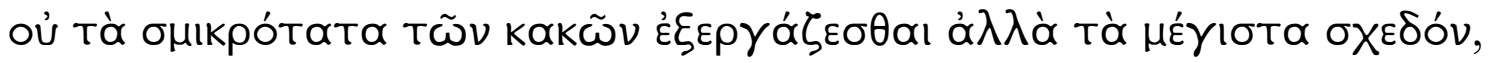

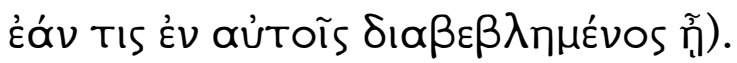

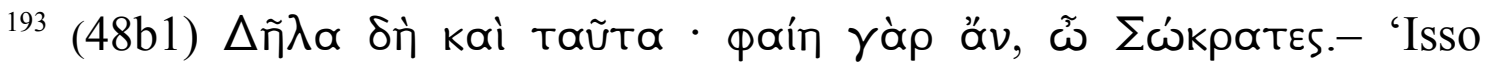
também é evidente, porque alguém diria isso, Sócrates'.

Este trecho é bastante controverso. Adam, por exemplo, considera

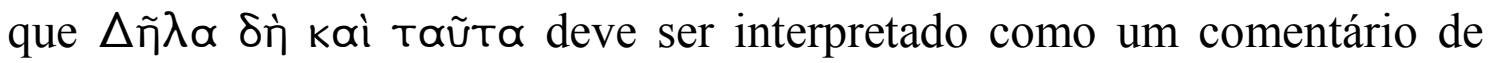
Críton feito em voz baixa dando seu assentimento ao conteúdo daquilo que Sócrates acabou de dizer, isto é, de que a maioria tem o poder de matá-los;

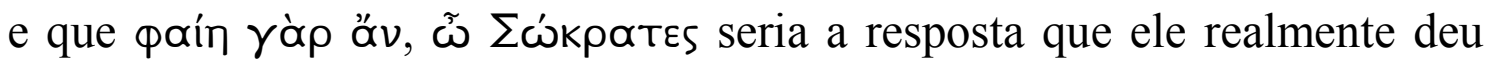
em voz alta, a que Sócrates ouviu e interpretou como sendo uma concordância com o fato de que alguém realmente levantaria a objeção que Sócrates tinha acabado de citar. A fala seguinte de Sócrates, iniciada com 


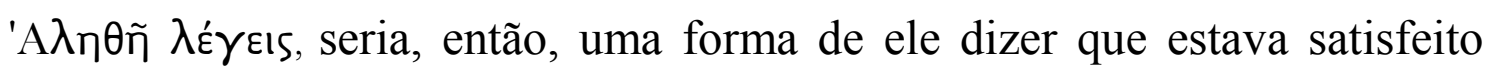
com a resposta dada pelo amigo (PLATO, 1997a, pp. 52). Burnet, por sua

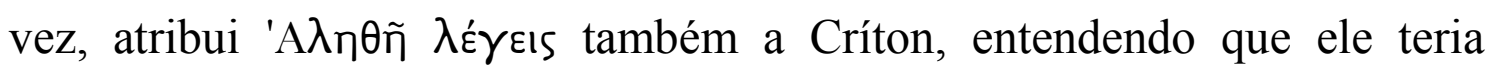
concordado, então, inteiramente com a dita objeção levantada por Sócrates, o que faz de Críton alguém não muito preocupado em manter um pensamento coerente. Obviamente não é possível saber qual leitura seria a mais fiel, assim optei por manter 'A $\lambda \eta \theta \tilde{n} \lambda \varepsilon \dot{\gamma} \varepsilon ı$ (OGT) como parte da fala de Sócrates e por interpretar a resposta de Críton como sendo uma confirmação de que o argumento de Sócrates como um todo lhe fazia sentido.

194 (48b2) $\dot{\alpha} \lambda \lambda \alpha$ - Ver nota em 44c6.

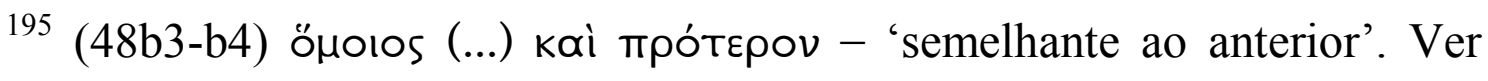
nota em (46b8-c2).

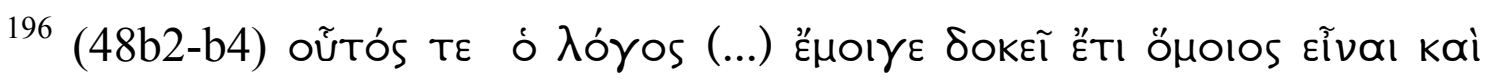

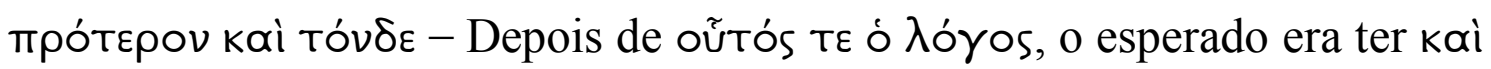

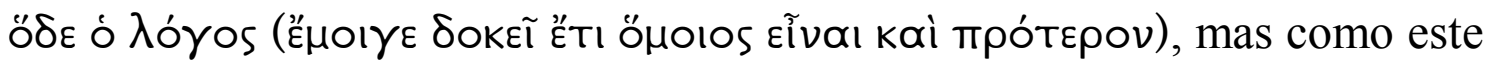

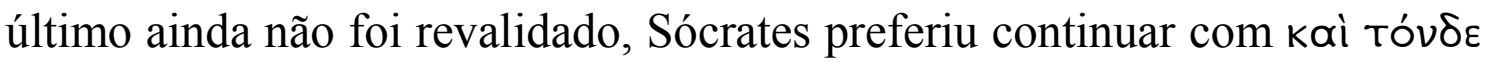

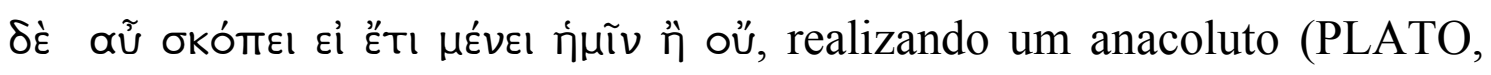
1997a, pp. 52).

197 (48b4) бKómeı - ver também nota em $46 b 3$.

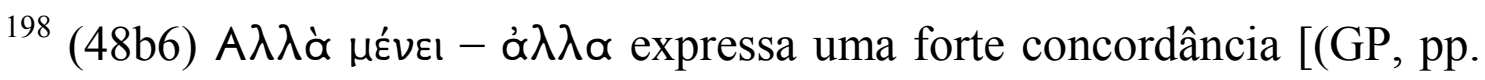
20) e (PLATO, 2001a, pp. 68)]: 'Certamente permanece.'

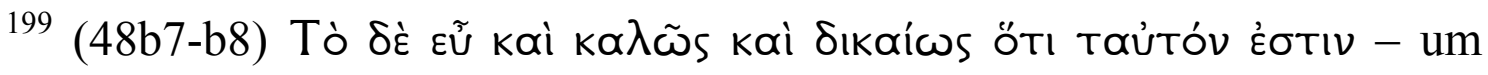
único artigo colocado diante do primeiro de uma série de dois ou mais nomes conectados por kai produz o efeito de uma única noção. A repetição do artigo, por outro lado, colocaria ênfase em cada nome da série (GG, sec.

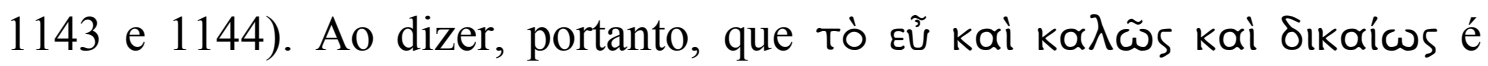


Taủtóv, Platão estaria enfatizando que a unidade formada pela série acima deve ser entendida como uma identidade.

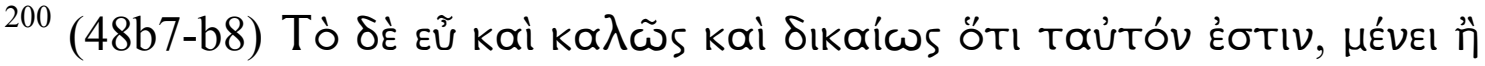

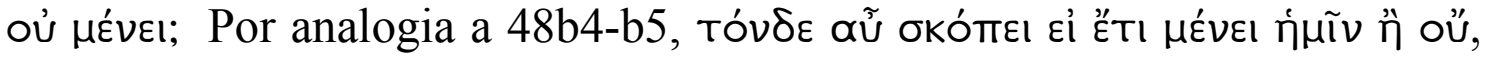

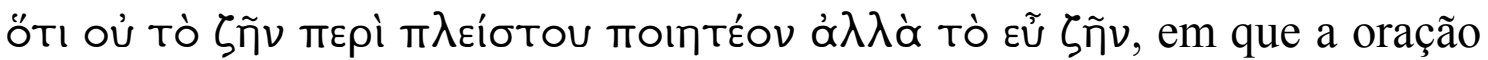

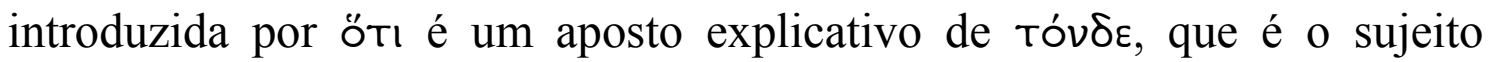

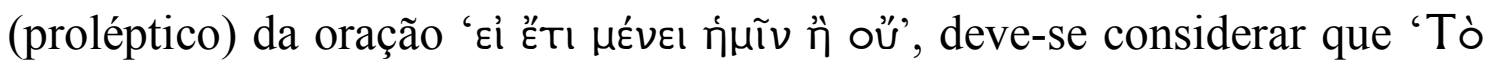

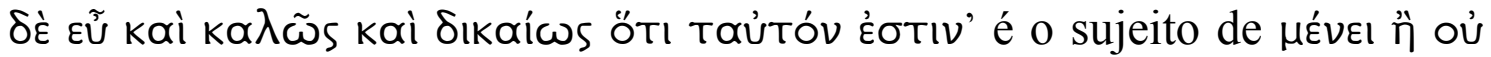
$\mu \varepsilon ́ v \varepsilon 1$.

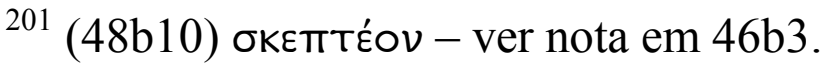

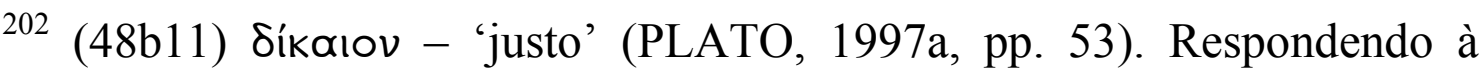

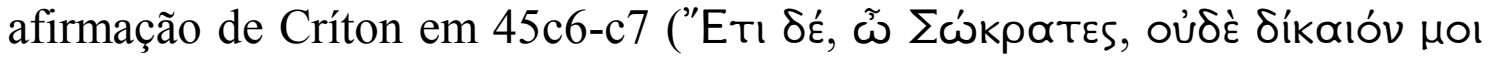

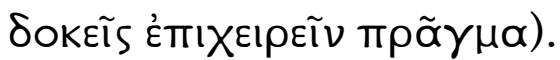

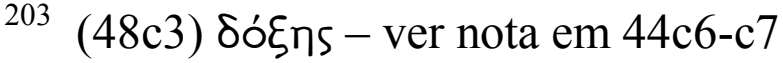

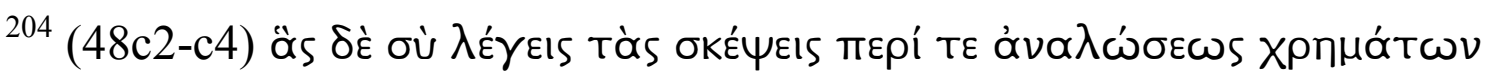

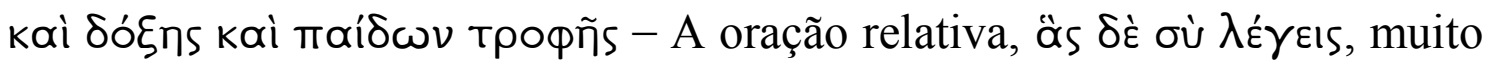
provavelmente para enfatizar o autor das observações, où, precede o

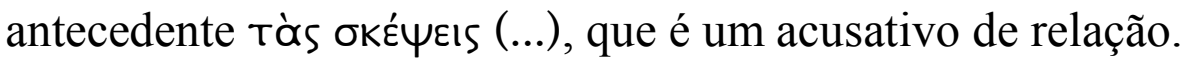

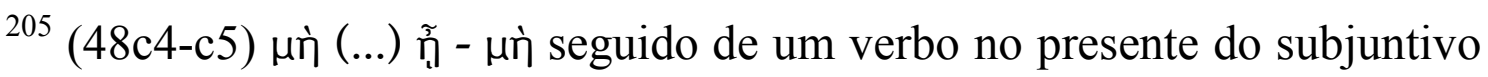
expressa uma asserção duvidosa (GG, sec. 1801): 'suspeito que sejam (...)'. Ver nota em $45 \mathrm{e} 1$.

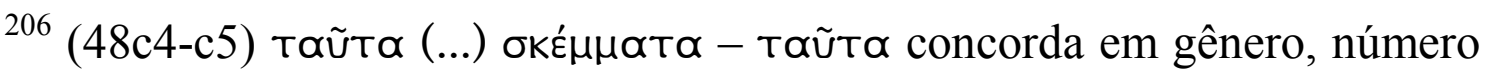

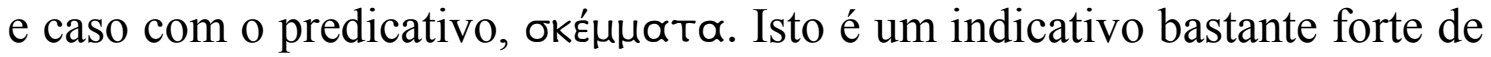

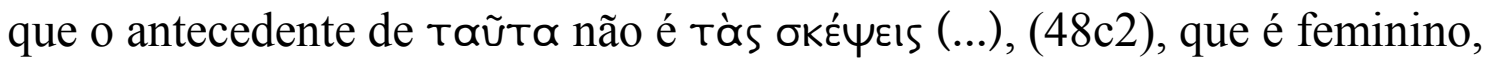
mas alguma idéia contida ou implicada nesta expressão (GG, sec. 1253).

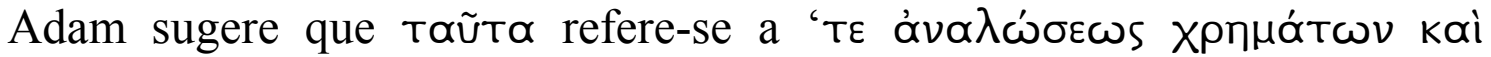

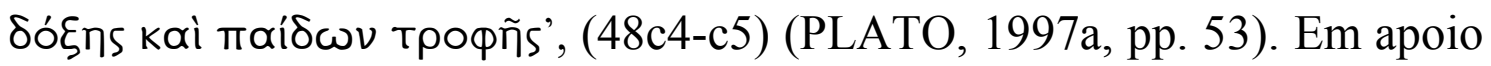


a essa hipótese, podemos citar os sentidos que Chantraine atribui,

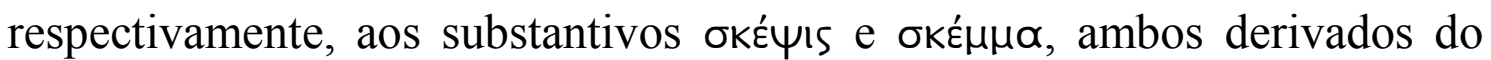

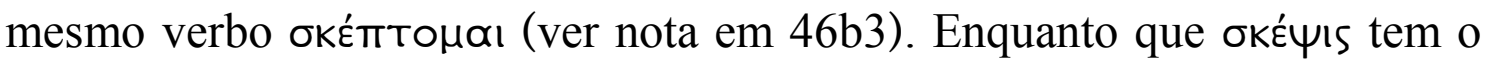

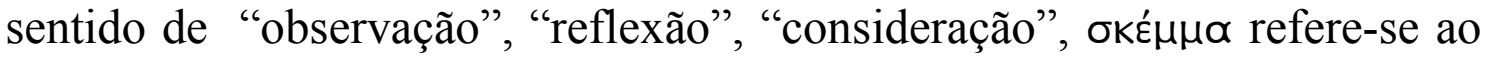
"assunto da reflexão", à "questão", ao "problema" (CHANTRAINE, pp. 1014), o que, neste trecho, corresponderia justamente a ' $T \varepsilon$ ó $v \alpha \lambda \omega$ ' $\sigma \varepsilon \omega s$

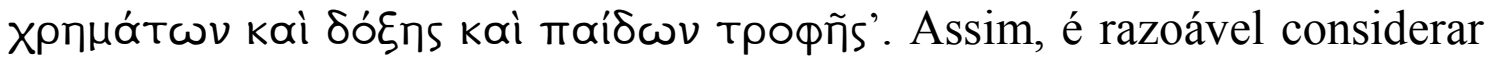

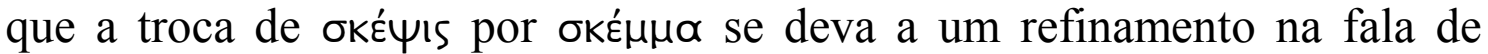
Sócrates, que não deveria ser ignorado. A maioria dos tradutores, porém,

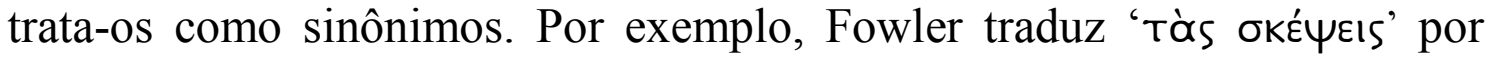

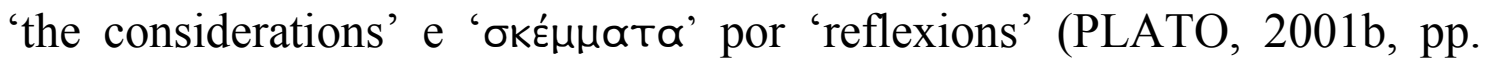
169), enquanto que Croiset traduz ambos (o segundo, omitido, é subentendido) por 'considérations' (PLATON, 2002, pp. 224). É, no entanto, difícil diferenciar os dois termos na tradução: tendo optado por

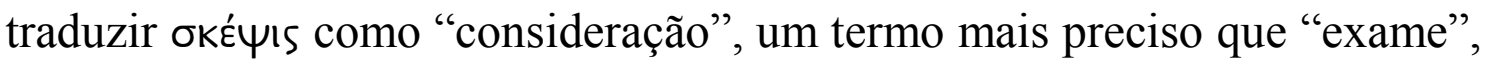
neste contexto, escolhi traduzir $\sigma K \varepsilon ́ \mu \mu \propto$ pela perífrase "questão própria para

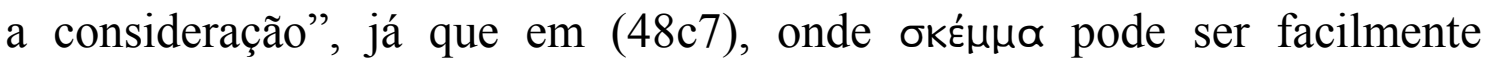
subentendido e suprido (ver nota ad loc.), o termo "questão" parece traduzi-lo adequadamente.

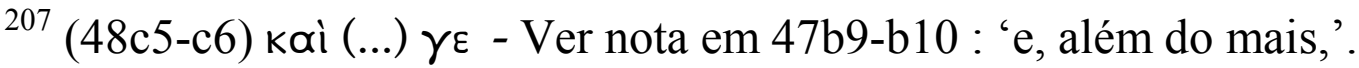

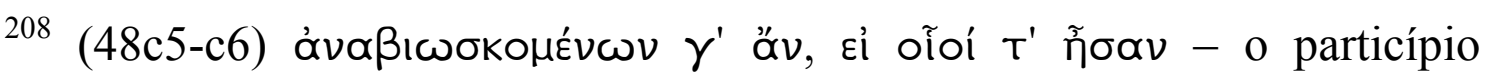
seguido de ớ $v$ deve ser entendido como equivalente a uma apódose com o verbo no imperfeito do indicativo seguido de ơ̌ (irreal do presente) cuja prótase é eỉ oĩoí T' ñoav, (GG, sec. 2050a, 2146).

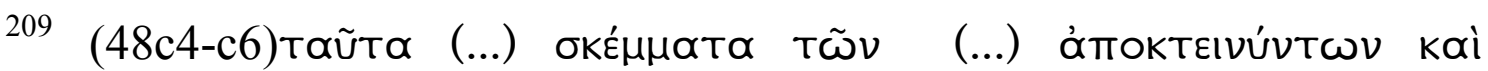

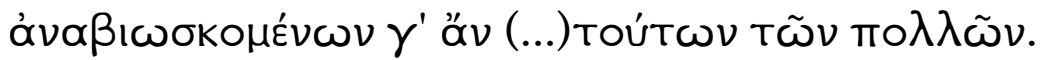

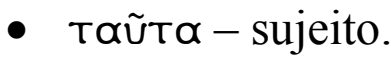




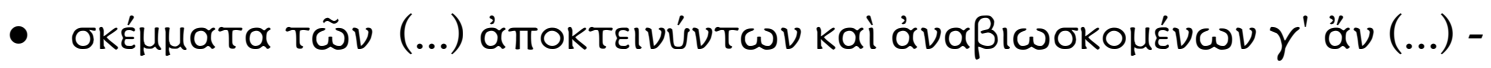
predicativo (PLATO, 1997a, pp.53-54)

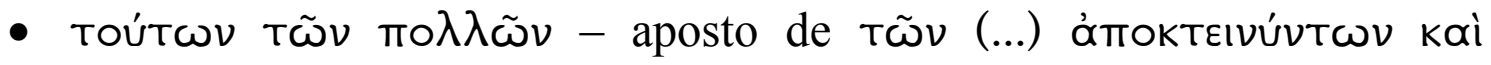

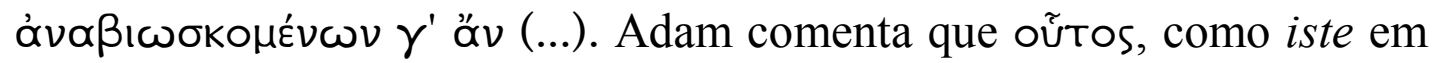
latim, denota desprezo (PLATO, 1997a, pp. 54). A oposição entre oi

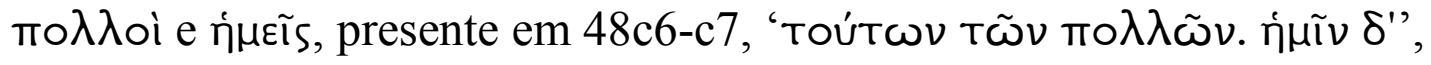
parece confirmar isso.

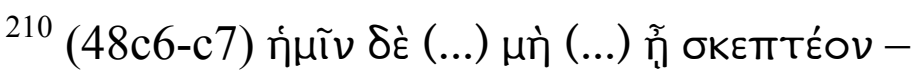

- $\delta \grave{~}$ - Conectivo com forte sentido adversativo (GP, pp. 166): 'Porém', 'no entanto'.

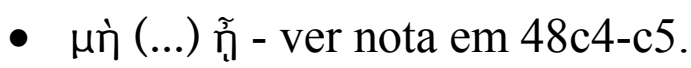

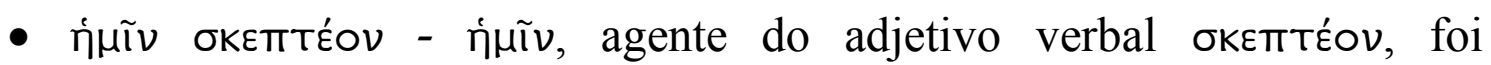
estrategicamente colocado nessa posição para que contrastasse com

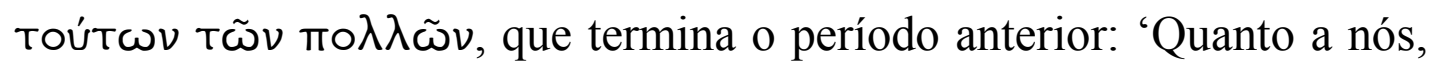
no entanto, suspeito que (...)'.

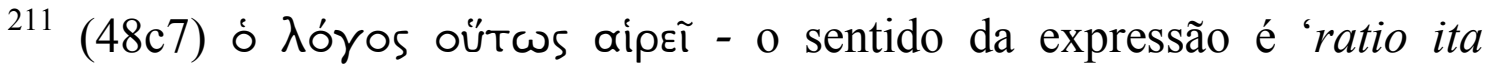
evincit', 'o raciocínio assim demonstra', segundo Adam e Burnet [(PLATO, 1997a, pp. 54) \& (PLATO, 1979, pp. 276-277)], e seu uso não se iniciou com Platão - Heródoto já a utilizava (Hdt., 2.33). Porém a tradução literal de aipeĩ por 'escolhe' parece combinar melhor com a importância que Sócrates atribui ao raciocínio no diálogo - o papel de 'condutor'.

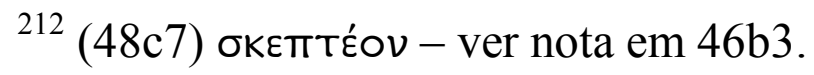

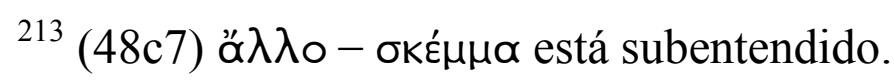

${ }^{214}$ (48d1) kaì đủToì - Ver nota em 45c1 


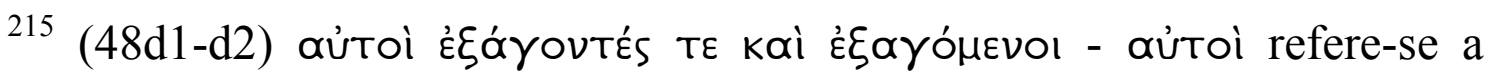

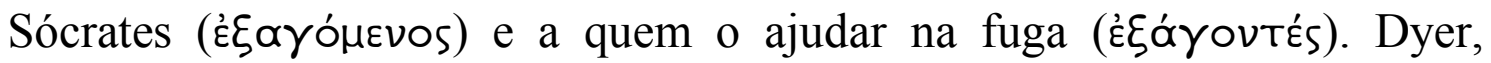

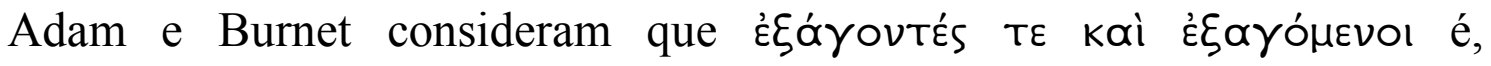

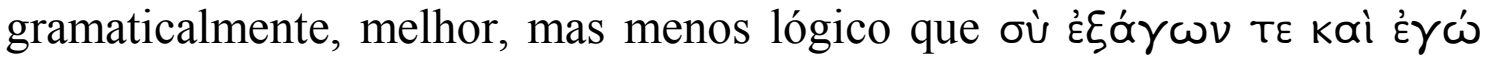

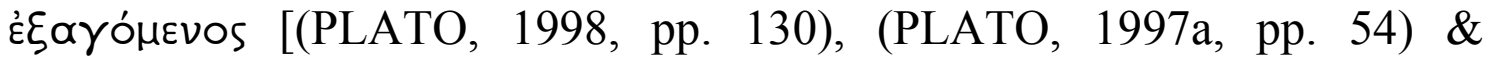

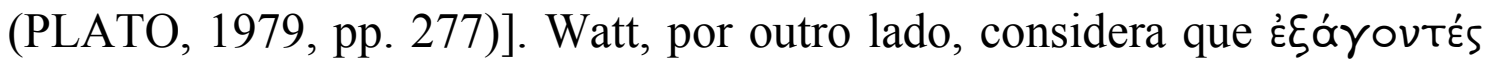
refere-se não somente a Críton (où acima) mas a todos os amigos de Sócrates que o ajudassem na fuga (PLATO, 1927, pp. 47). Da minha parte, não vejo por que não dar razão a Watt, já que está explícito no diálogo (44e) a participação de outros amigos na fuga.

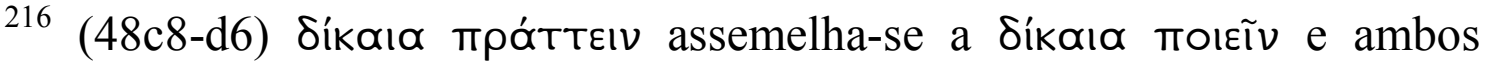

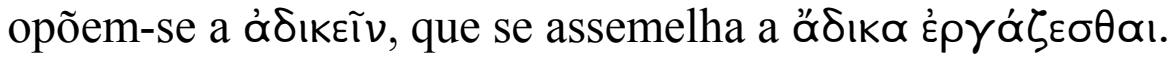

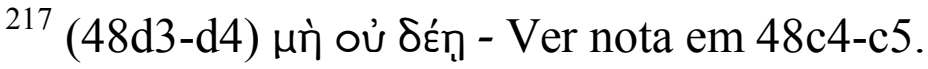

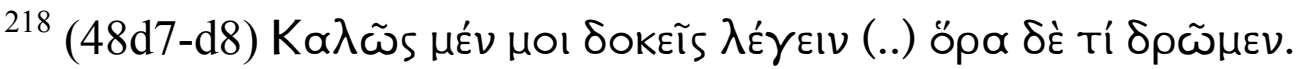

- tí $\delta \rho \tilde{\mu} \mu \varepsilon v$ - subjuntivo deliberativo. Para Críton, não é hora de palavras, mas de decisão, conforme já havia dito em 46a4-a5 ( $\dot{\alpha} \lambda \lambda \dot{\alpha}$

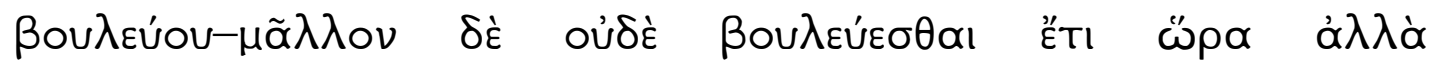
$\beta \varepsilon \beta O U \lambda \varepsilon \tilde{\sigma} \sigma \theta \alpha$ ) (PLATO, 1997a, pp. 55).

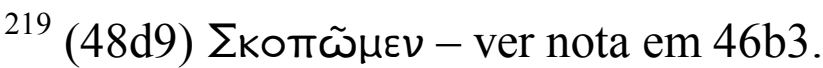

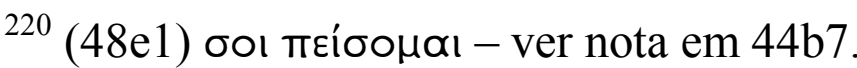

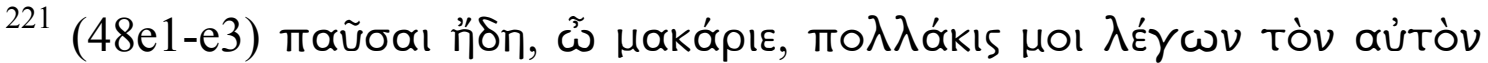

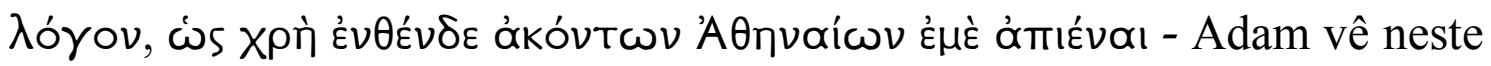
trecho e em 44b6-b7 uma prova de que ambos já tenham tido esta conversa anteriormente (PLATO, 1997a, pp. 28).

222 (48e4) $\pi \varepsilon i ́ \sigma \alpha \varsigma$ $\sigma \varepsilon$ - ver nota em 44b7.

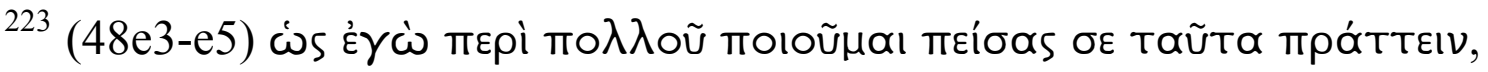

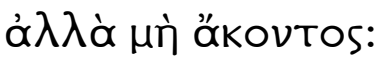




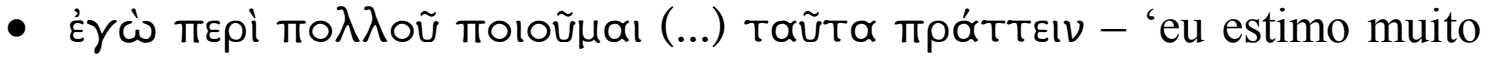
agir', 'eu acho importante agir'. TaũTa pode ser tratado como um acusativo de relação cujo referente seria a questão sobre a qual estão

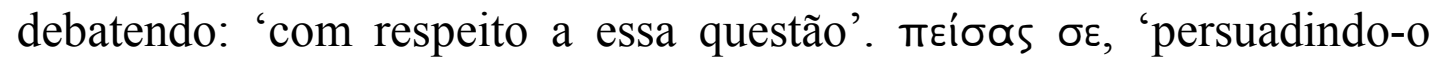

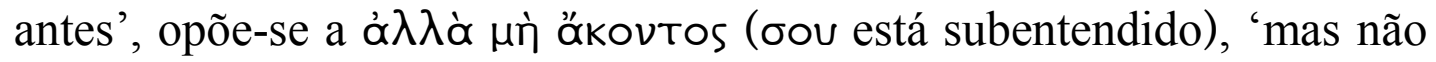
sem o seu consentimento'.

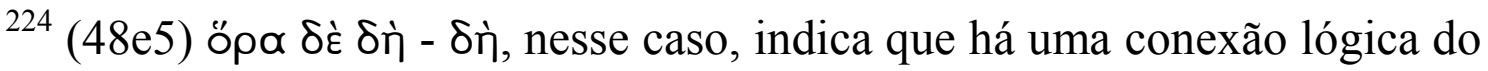
comando que a precede, 'observe', com a sentença anterior, conforme nota em 47a2: 'Assim, observe'.

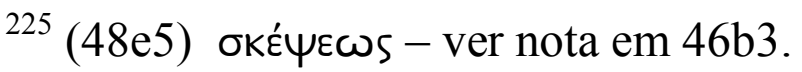

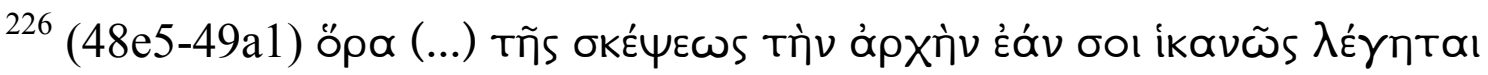

- Éáv deve ser tratado como uma conjunção condicional, nunca como uma conjunção integrante, introduzindo uma interrogativa indireta (GG, sec. 2354, 2672).

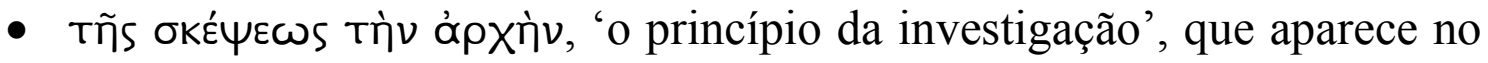

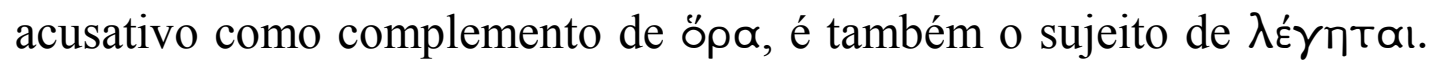
O dito princípio será lentamente construído em 49a4-c9, enunciado em 49c10-c11 e reiterado como tal em 49d7-d9.

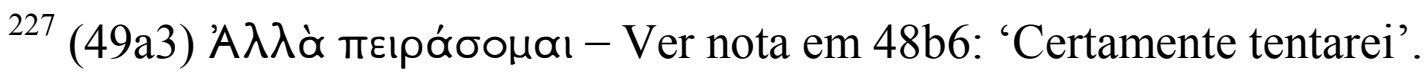

${ }^{228}$ (49a4-c11) Para uma análise detalhada deste trecho vide o capítulo 'A Retaliação no Criton'.

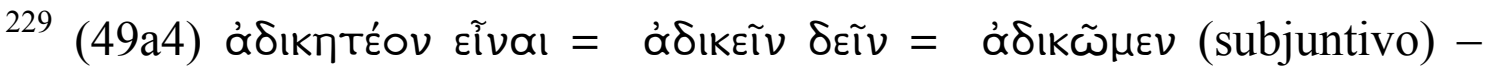
Todas estas formas poderiam ser igualmente usadas numa questão deliberativa (GG, sec. 2639).

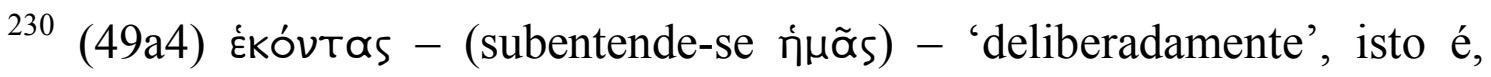
'com conhecimento acerca do que faz e sem ser obrigado'. 


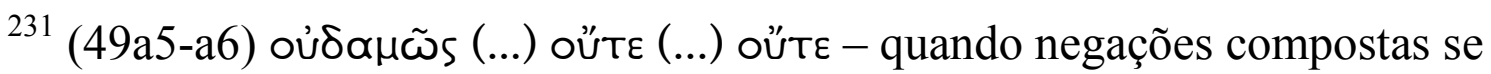
sucedem, elas não se anulam, mas reforçam-se (BIZOS, pp. 210).

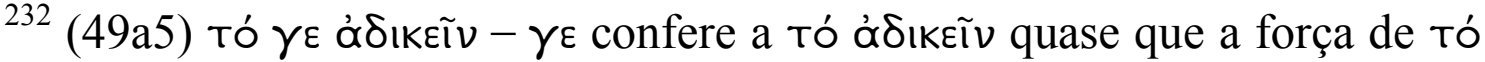

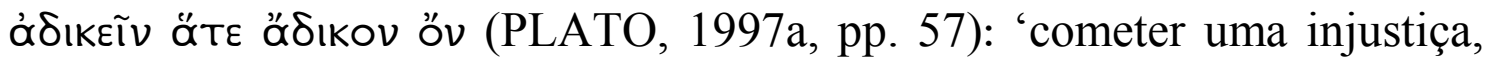
porque é injusto'.

233 (49a9) ăpa - expressa surpresa por ter apreendido algo diferente daquilo que se supunha com relação a um fato passado (GP, pp. 36-37): 'como agora se evidencia'.

${ }^{234}$ (49b3) kaì عîtт - 'ou melhor, se (...)'. Ver nota em 45c1.

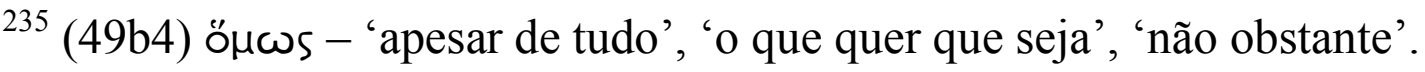

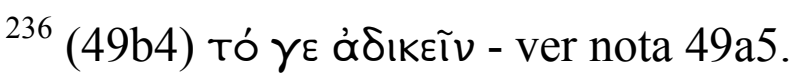

${ }^{237}$ (49b7) ăpa - nesse caso, embora marque uma decorrência lógica, fá-lo de um modo mais coloquial e expressando surpresa por sua descoberta (GP, pp. 41): 'então'.

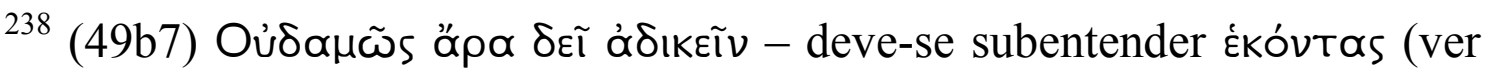
nota em 49a4): para o Sócrates da Apologia, que penso ser o mesmo do Criton, só faria sentido que alguém fizesse algo que, em última instância, prejudicasse a si mesmo, se ignorasse o resultado de seu ato:

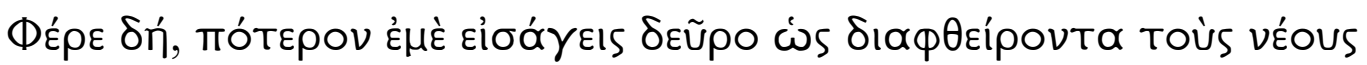

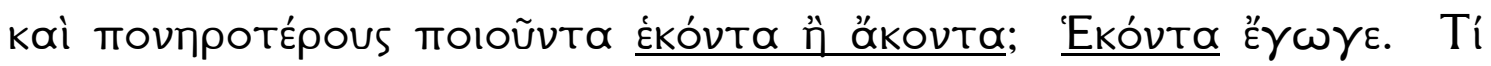

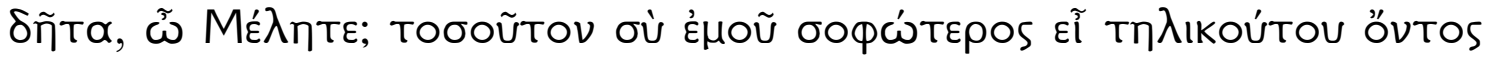

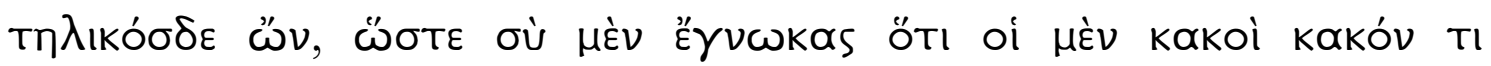

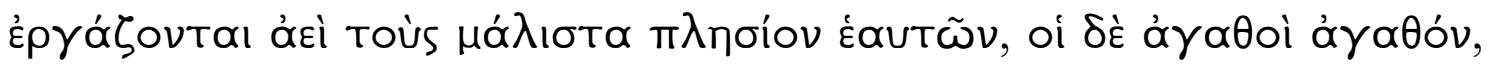

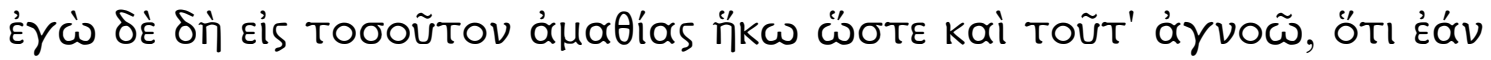

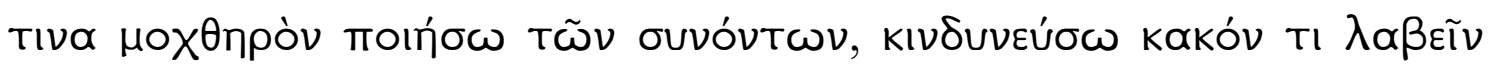

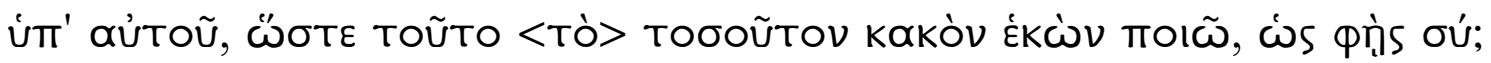

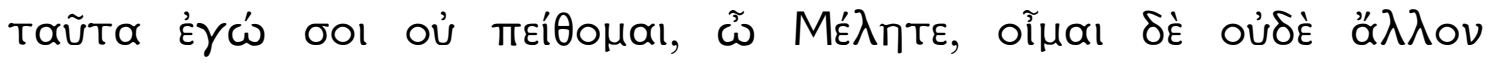




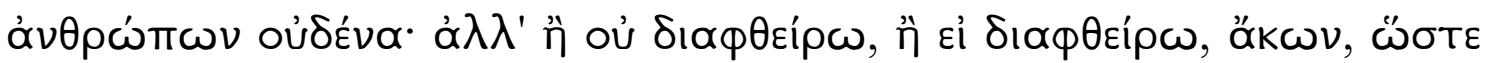

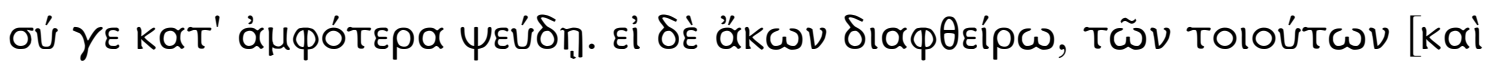

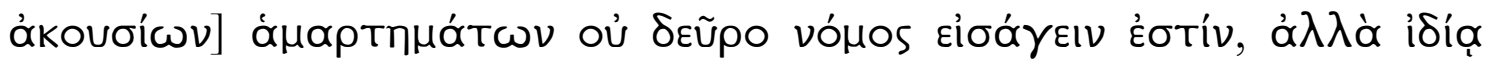

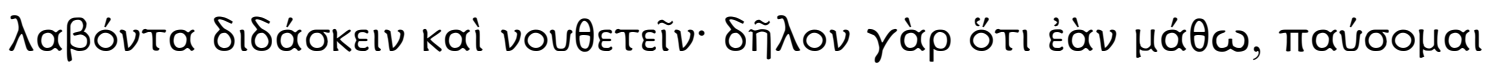

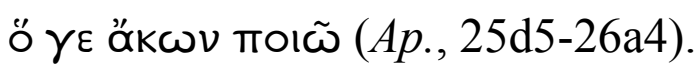

"Vamos, você me traz aqui porque corrompo os jovens e torno-os piores deliberadamente ou sem que eu saiba? Deliberadamente. O quê, Meleto? Você, jovem como é, é assim tão mais sábio que eu, velho como sou, que acaba de reconhecer que os maus realizam sempre algo mau aos que estão mais próximos de si mesmos, mas os bons, algo bom, enquanto que eu alcancei um tal grau de ignorância que também isso ignoro - que se algum dos meus companheiros eu tornar desprezível, correrei o risco de receber um mal da parte dele - de modo a fazer tal mal deliberadamente, como você afirma? Quanto a isso não me deixo persuadir por você, Meleto, e de modo algum presumo que algum outro homem se deixe. Mas ou não corrompo ou, se corrompo, faço-o sem saber, de modo que você, segundo ambas mente. Se corrompo sem saber, não é a lei me trazer aqui por conta de tais e involuntários erros, mas, tomando-me separadamente, ensinar-me e censurar-me. Pois é claro que, se eu aprender, pararei de fazer o que faço sem saber".

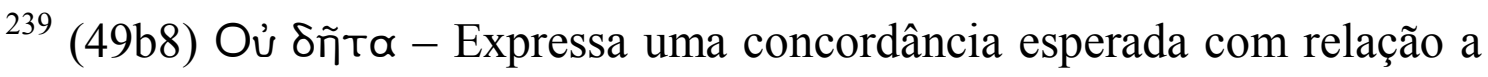
uma negativa feita pelo falante anterior (GP, pp. 274): 'Certamente não!'. Emlyn-Jones nota que Críton é caracterizado por Platão como alguém que alterna momentos de plena anuência aos princípios socráticos com outros em que tais princípios parecem esquecidos (PLATO, 2001a, pp. 72).

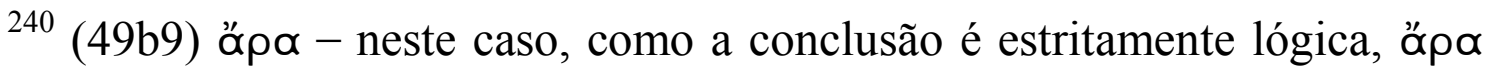
significa 'portanto' (PLATO, 1997a, pp. 58). 


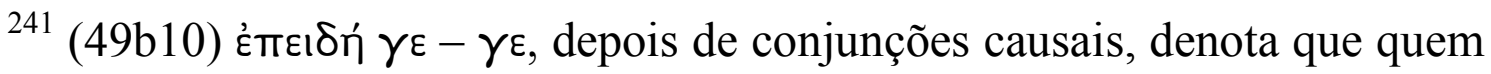
fala está apenas preocupado com o que está estabelecido na oração subordinada que o par em questão introduz, podendo isto ser ou não verdadeiro (GP, pp. 141-143). Neste caso, Sócrates está somente seguindo o seu raciocínio: uma vez que de modo algum se deve cometer uma injustiça, obviamente também não se deve revidar com uma injustiça, ao se sofrer uma injustiça: 'Já que, obviamente, ...'

${ }^{242}$ (49c1) Oủ paívetaı - oủ é privativo (GG, sec. 2691), como em oü $\phi \eta \mu$, que significa 'nego', 'afirmo que não', não 'não digo'. Como o verbo paívouaı pode construir-se, com sentidos distintos, com um verbo no infinitivo ou no particípio, podemos interpretar a expressão de dois modos. Como Fowler, 'Apparently not' [(PLATO, 2001b, pp. 173) \& (PLATO, 1998, pp. 132)], pressupondo que Críton quis dizer Oủ qaívetaı ठEĨv, ou como Croiset, 'Cela est évident' (PLATON, 2002, pp. 225), entendendo

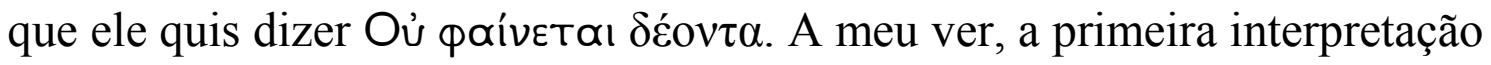
é a que faz mais sentido, porque evidencia a ambigüidade da resposta de Críton, que pode ser interpretada como uma hesitação de sua parte entre deixar-se levar pelo raciocínio - como concordou em proceder (ver nota anterior e 48c7) - e ser fiel às suas crenças a respeito desta questão especificamente, que parecem estar de acordo com as da maioria. As demais respostas de Críton no trecho 49b6 e 49c9 são enfáticas e não contém qualquer ambigüidade.

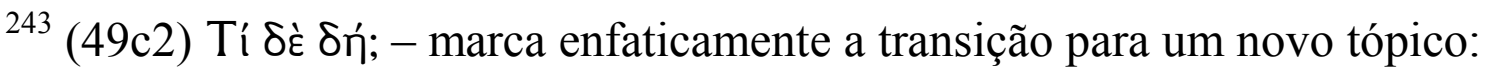
'E quanto a isso aqui:'

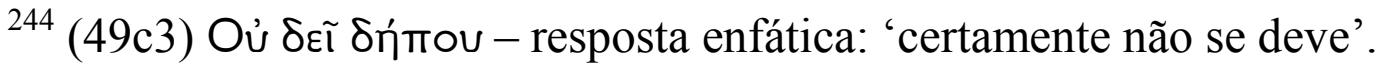

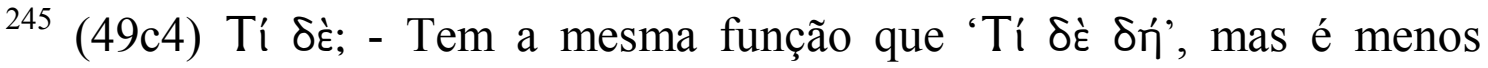
enfático. 


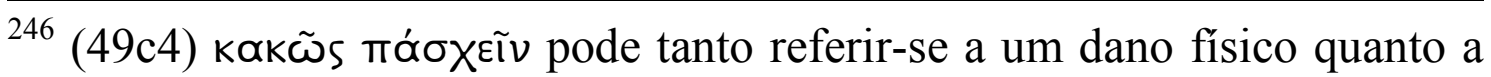
um dano moral.

${ }^{247}$ (49c10) äpa - 'portanto' - ver nota em 49b9.

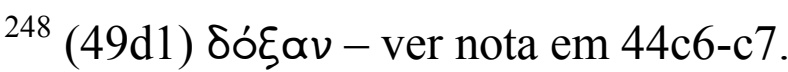

249 (49d3) oũv - confirmativo (GG, sec 2956): 'na verdade', 'de fato'.

${ }^{250}$ (49d3-d4) koıvì ßou入ń - 'uma base comum para a deliberação', 'uma premissa comum'. Não é possível, segundo Sócrates, deliberar sem que haja uma koıvì ßou入ń. No entanto, ele não afirma que seja impossível discutir o assunto.

${ }^{251}$ (49d4) $\alpha \dot{\alpha} \lambda \lambda \grave{\alpha}$ - Neste caso, a partícula não tem sentido adversativo, mas progressivo, equivalente a kai (GP, pp.21-22).

252 (49d5) бKótrєı - ver também nota em $46 b 3$.

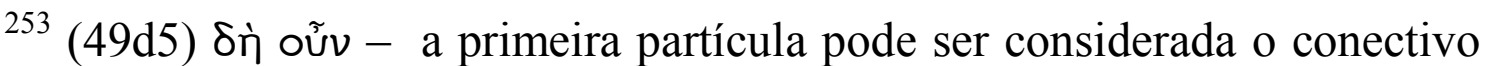
enquanto que a segunda, um extra de difícil tradução (GP, pp. 468-470). Depois de um imperativo, ठ̀̀ pode ser traduzido como 'assim', 'então'. Ver nota em $47 \mathrm{a} 2$.

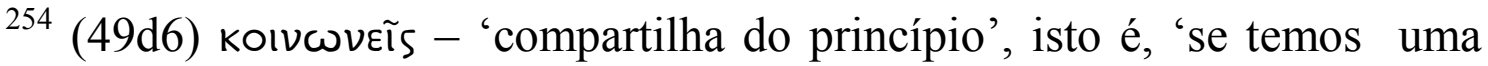

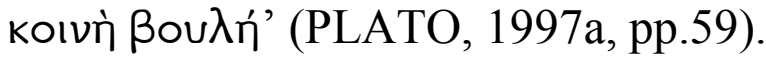

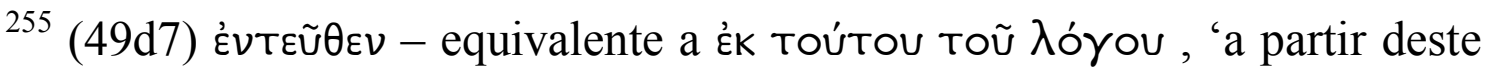

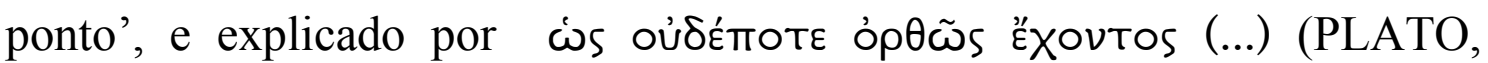
1997a, pp. 59).

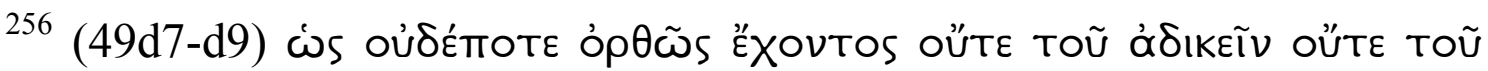

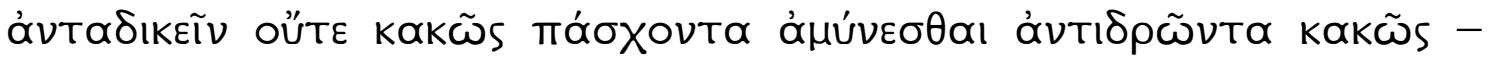
genitivo absoluto precedido de ஸ́s na função de aposto (ver nota anterior)

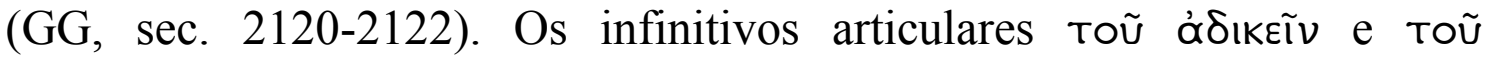

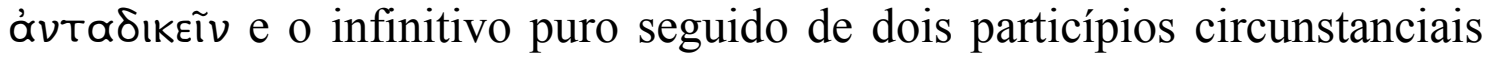
no acusativo são todos sujeitos de ÉxovTos. 


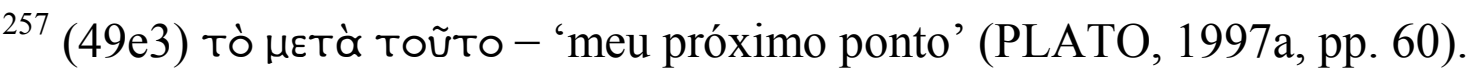

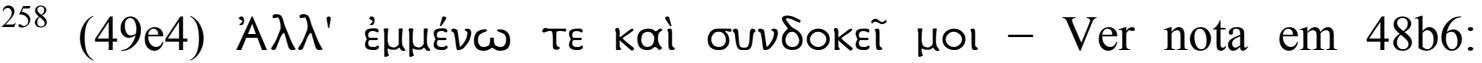
'Certamente não só permaneço ...'.

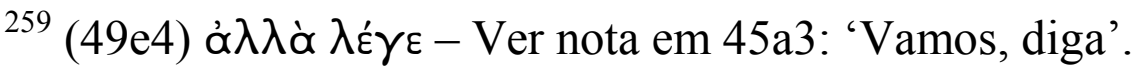

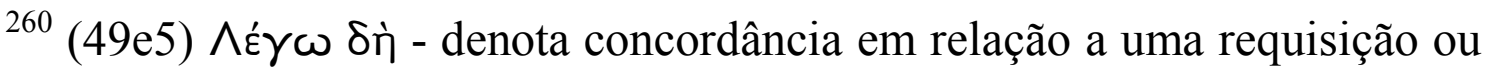
comando da outra parte (GP, pp. 227), no caso ' $\lambda \varepsilon ́ \gamma \varepsilon$ '.

${ }^{261}$ (49e5) $\mu \tilde{\alpha} \lambda \lambda$ ov $\delta \dot{\varepsilon}$ - 'ou melhor'. Ver nota em 46a4.

${ }^{262}(49 \mathrm{e} 6) \mathrm{T \omega}($ enclítico $)=$ Tıvı.

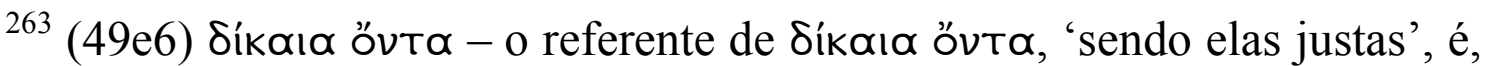
obviamente, ä, traduzido como 'certas coisas', porém não está claro se o que deve ser justo é o conteúdo do que foi acordado, pura e simplesmente, ou se as condições em que se deu o acordo também devem ser levadas em conta. Admitindo-se a primeira hipótese, um acordo conseguido sob tortura teria a mesma validade que outro feito sem coerção, desde que o conteúdo acordado fosse justo. A segunda hipótese, por sua vez, rejeitaria o acordo feito sob tortura. Além dessa ambigüidade, há outra referente ao tempo em que o conteúdo do acordo deve ser considerado correto, uma vez que ä é o

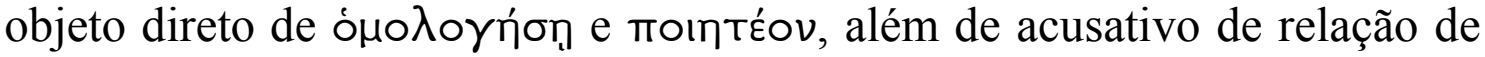

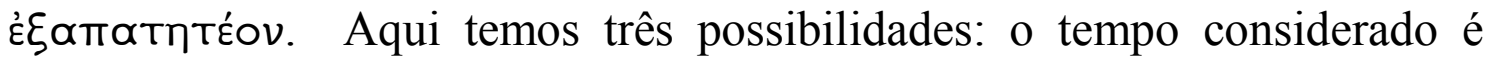
aquele em que se deu o acordo, aquele em que se decide cumpri-lo ou não, ou ambos. Há uma passagem na República, ( $R ., 331 \mathrm{c} 5$ ss) em que Sócrates insiste que não é justo nem devolver a espada ao amigo de quem a tomou emprestado se ele tiver ficado louco nem lhe dizer a verdade nas mesmas condições. Nesses dois exemplos, ele está certamente levando em conta ambos os tempos: aquele em que se deu o acordo e aquele em que teve que se decidir sobre cumpri-lo ou não. 


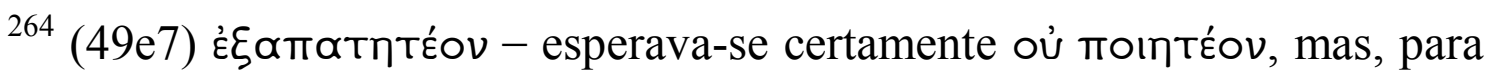
Sócrates, não é possível que alguém acredite que deva fazer $\mathrm{X}$, porque $\mathrm{X}$ é o justo a ser feito, mas faça o oposto de $\mathrm{X}$, com conhecimento de que faz o oposto de X e sem ser compelido a isso (PLATO, 1997a, pp. 60).

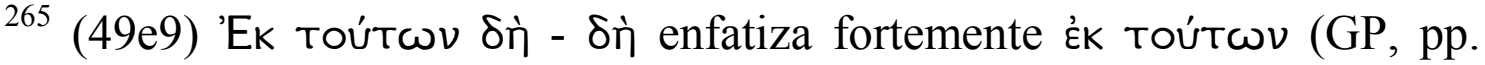
208-209): 'a partir especificamente disso'.

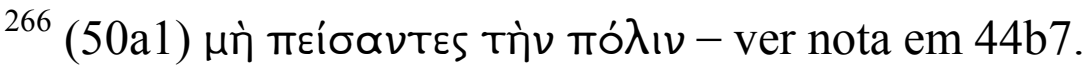

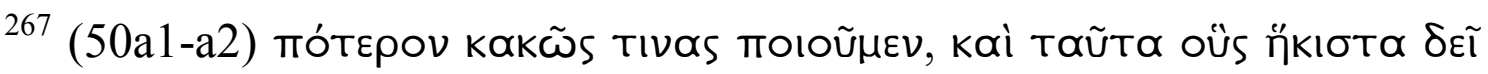

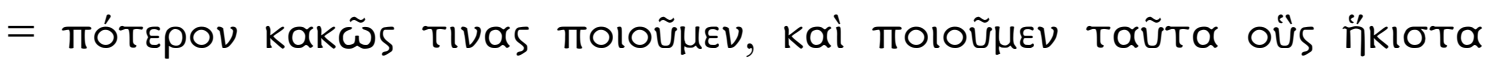

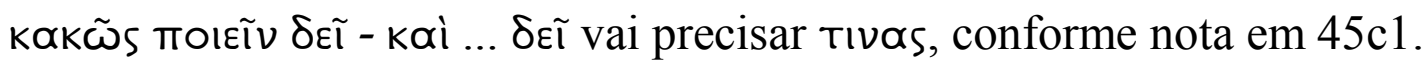

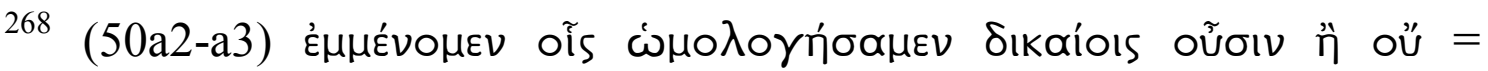

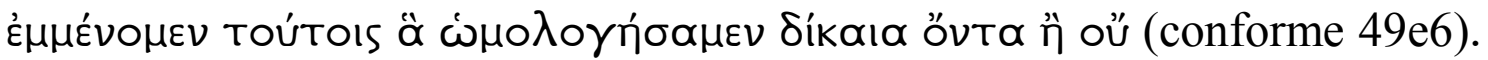

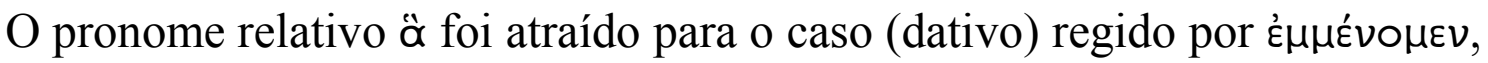
levando consigo Síkaı övтa.

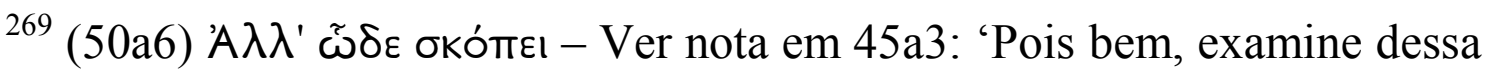
forma'. Quanto ao verbo oкómєı, ver também nota em 46b3.

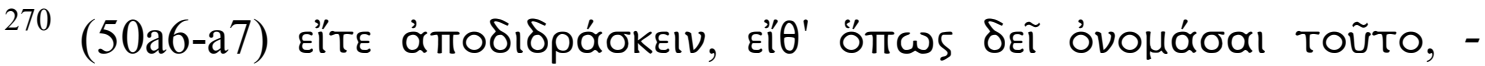

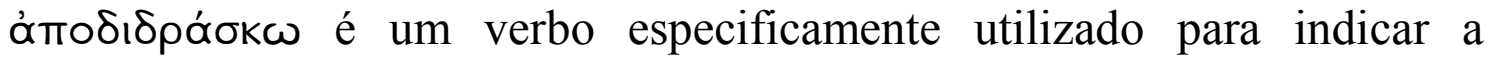
deserção de soldados ou fuga de escravos. Os verbos utilizados até agora

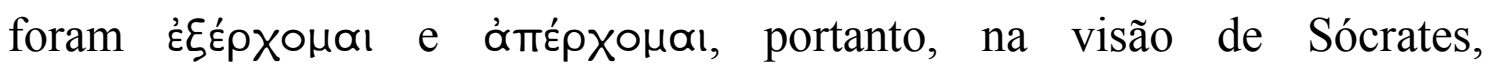
eufemismos. No entanto, ele concede que Críton nomeie o ato como quiser

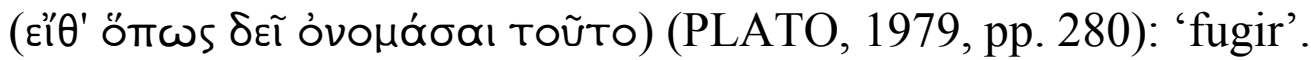

${ }^{271}$ (50a8) Tò koıvòv Tñs mó $\lambda \varepsilon \omega \varsigma$-Sócrates tem a intenção de fazer que 'as leis' sejam tomadas no seu mais amplo sentido, isto é, como representante da autoridade legal da cidade (PLATO, 2001a, pp. 75). Burnet (PLATO,

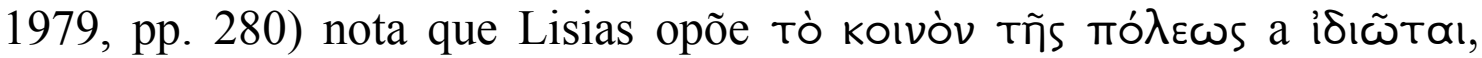


homens tomados privadamente (Lisias, Pro Mantitheo, seção 18, linha 7): 'interesse comum da pólis'.

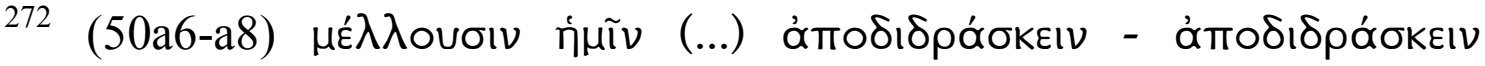

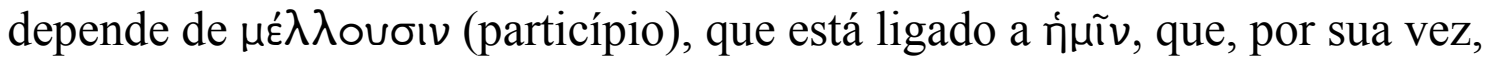

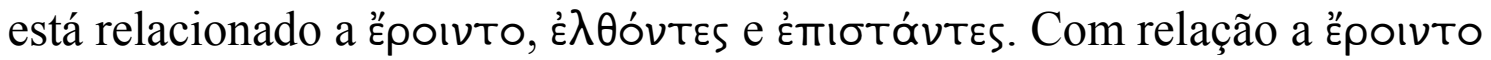
e ĖTाoTóvTEs, 'aparecer para' (como uma visão ou em sonho) (PLATO,

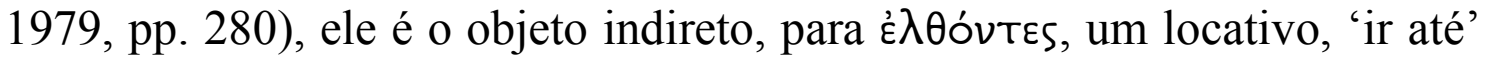
(para questionar, por exemplo). Por fim, podemos considerar que ambos os particípios marcam ações anteriores à marcada por époıvto, sendo que a de

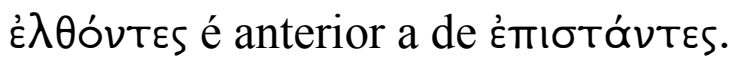

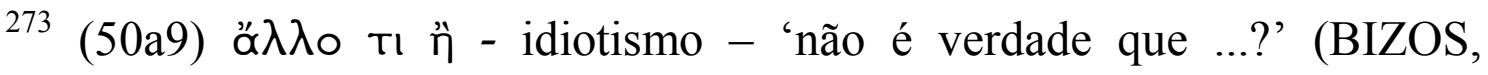
pp.149).

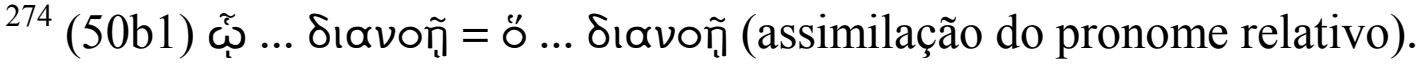

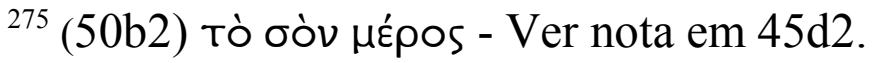

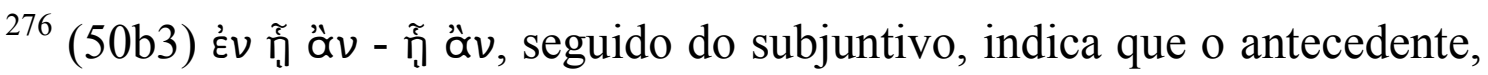

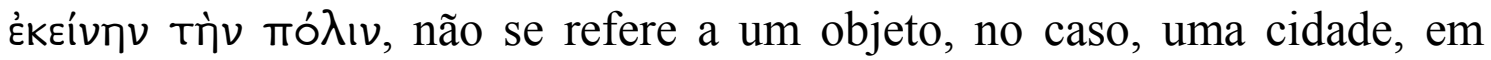
particular (GG, sec 2506).

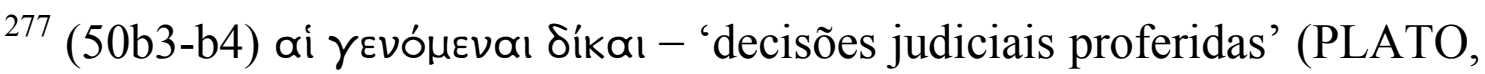
1997a, pp. 62).

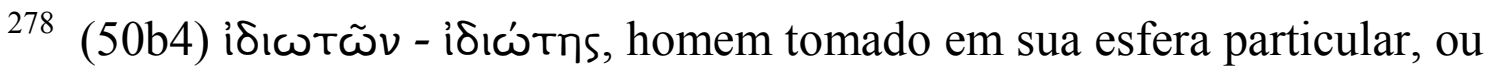
seja, na relação com seus familiares, escravos, propriedade (oĩkos) etc, opõe-se a mo入ítns, o cidadão, o homem tomado em sua esfera pública, ou seja, na relação com os demais cidadãos e sua pólis. Na falta de duas palavras, em português, que se oponham da mesma forma que as duas supracitadas, em grego, escolhi a perífrase "homens, no âmbito de seus

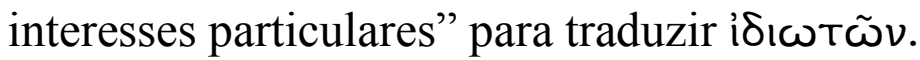




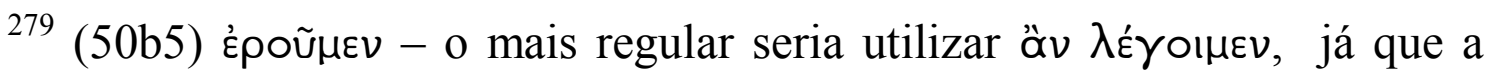
prótase utiliza o optativo (Époıvтo) (SMTGV, pp. 118).

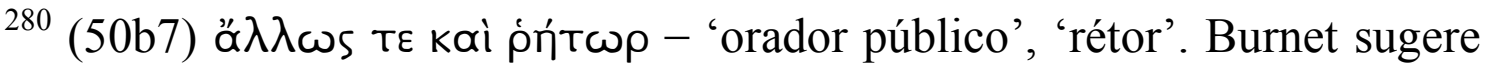
que Sócrates poderia estar referindo-se aos oradores públicos apontados

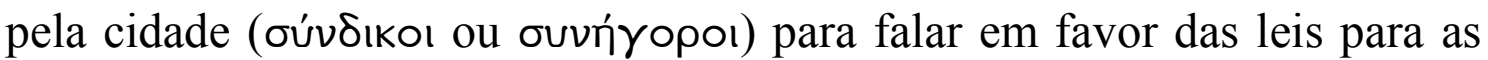
quais houvesse propostas com o intuito de aboli-las (PLATO, 1979, pp. 281). A lei, no caso, seria a que ordena que as decisões dos casos julgados

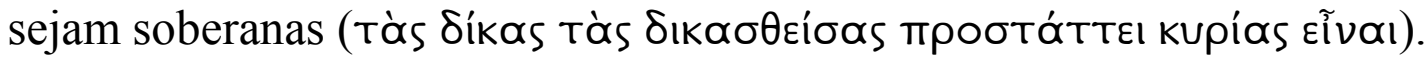

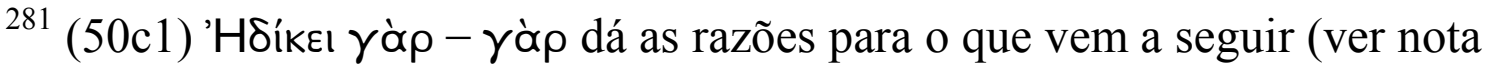
44e6): 'Sim , tentaremos isso, porque ...' (PLATO, 1997b, pp. 53).

${ }^{282}$ (50c5) Tí oũv ờ vómol

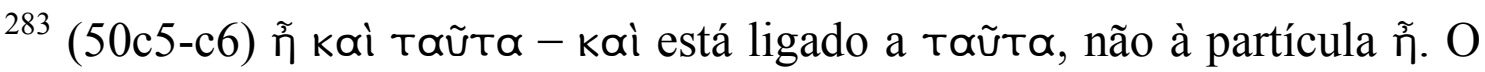

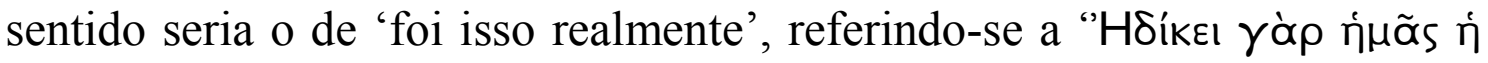

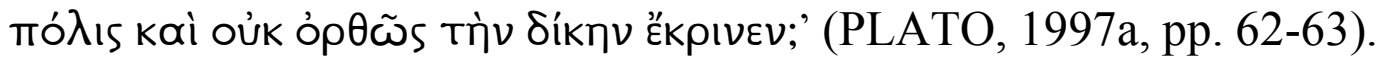

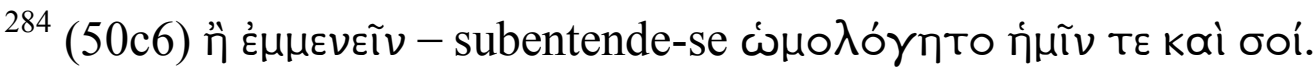

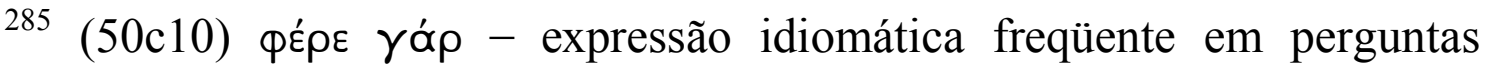
retóricas: 'bem (...)', 'agora (...)'.

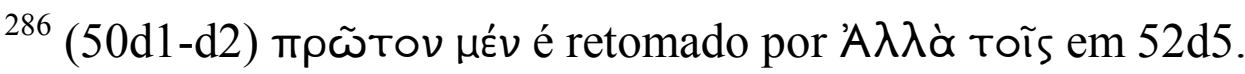

287 (50d2) kaì - explica a afirmação que acabou de ser feita, $\sigma \varepsilon$

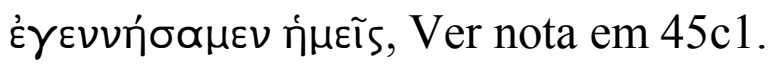

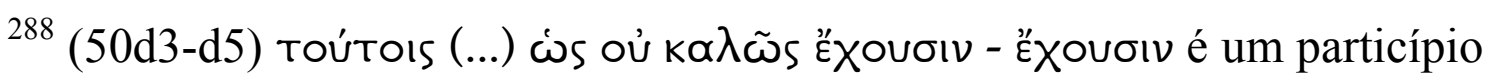
concordando com toútols. ஸ́s seguido do particípio expressa uma causa invocada, não necessariamente condizente com a realidade (BIZOS, pp. 181): 'sob o pretexto de que não sejam boas'.

289 (50d5) 'A $\lambda \lambda \grave{\alpha}$ - introduz uma questão após ter tido uma sugestão rejeitada (GP, pp. 9) : 'E quanto a ...'. 


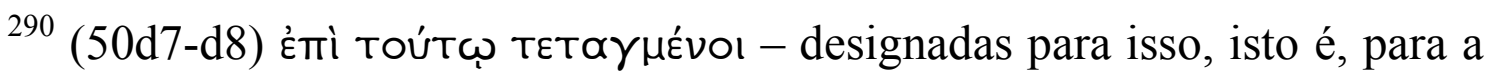
educação e assistência às crianças.

${ }^{291}$ (50e3) ஸ́s - ver nota em (53c7-c9).

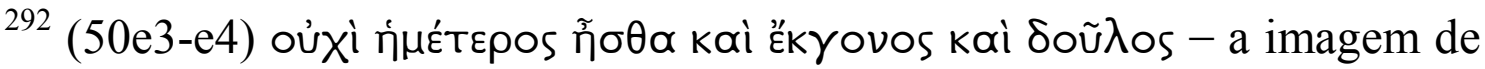
que os atenienses são como filhos das Leis já vem sendo construída por elas mesmas, mas a visão de que eles também sejam seus 'escravos' não decorre de seus argumentos. No entanto, esta visão parece ter sido um lugar comum nos séculos V e IV em Atenas, principalmente quando os gregos queriam diferenciar as suas póleis, onde o cidadão se sujeitava à lei, das organizações sociais dos não-gregos, nas quais eles se sujeitavam a indivíduos [(PLATO, 2001a , pp. 78) \& (PLATO, 1997a, pp. 64)].

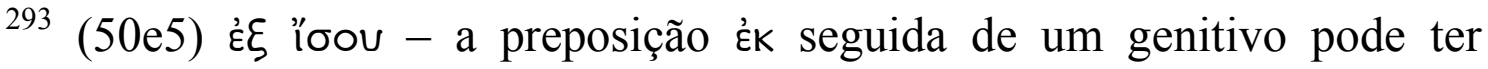
diversos sentidos: origem, conseqüência, causa, instrumento ou meio, ou conformidade (GG, sec 1688c). Neste caso, dado o caráter abstrato de toda a sentença em questão, não é possível precisar qual destes sentidos seria o

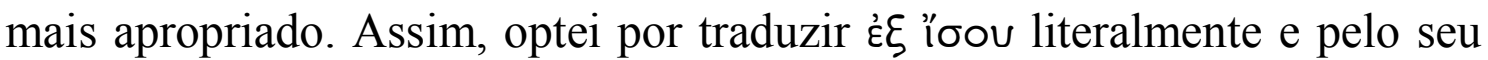
sentido mais comum, o de marcar a origem: 'a partir de uma igualdade'.

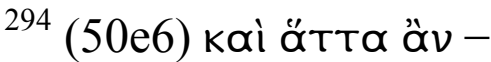

- kaì tem a função de precisar o que acabou de ser dito (PLATO, 1997a,

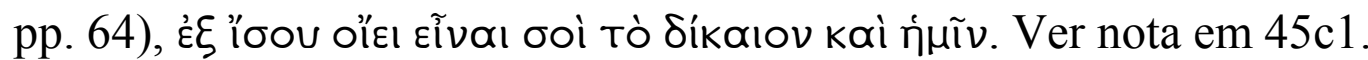

- ătra àv - a partícula å̀v seguida do subjuntivo indica que o antecedente de ớtт๙ é indefinido.

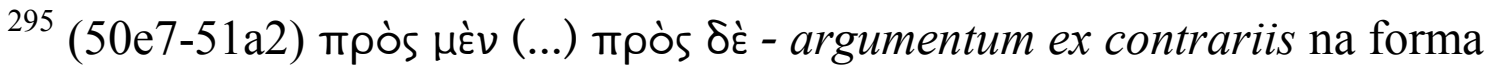
interrogativa (PLATO, 1979, pp.282). ${ }^{296}$ (50e7) ä $\rho \alpha$ - ver nota em 49a9: 'como era evidente'. 


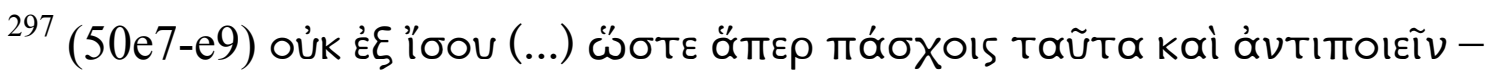

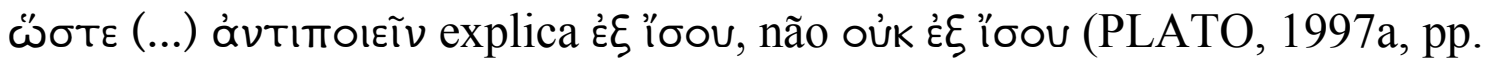
$65)$.

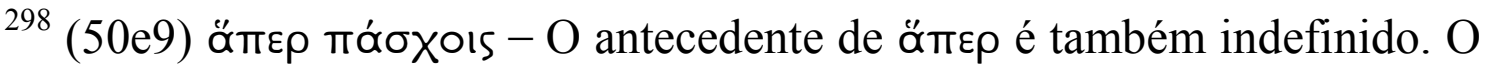
optativo foi utilizado no lugar do subjuntivo por conta do verbo da oração principal, ก̃v, estar em um tempo secundário.

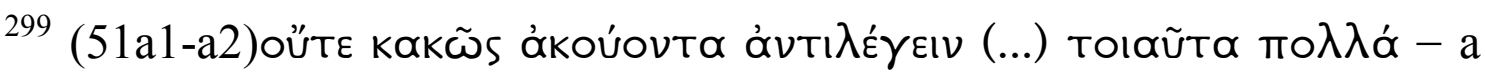
seqüência de orações coordenadas por oúte não dependem de

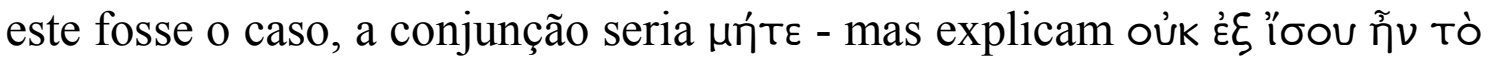

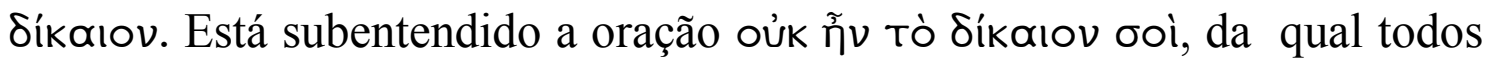
os infinitivos dependem (PLATO, 1997a, pp. 65).

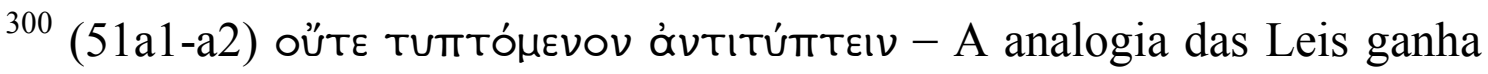
força no contexto ateniense, onde havia graves sanções para quem maltratasse os pais (PLATO, 2001a, pp. 79).

301 (51a3) öpa - ver nota em 49a9: 'como se evidencia' (pois o verbo da

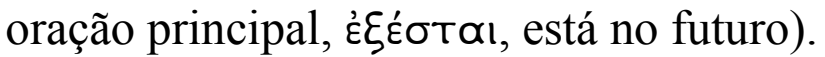

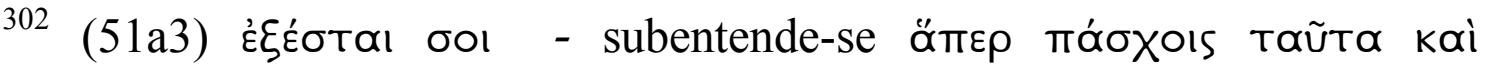

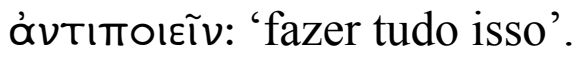

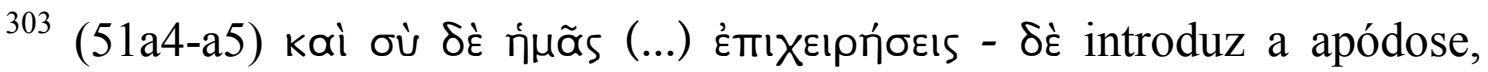

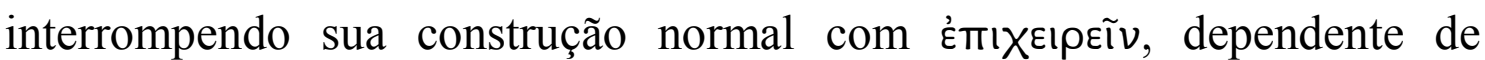
ڤँбтє. O efeito dessa construção é difícil de avaliar. Para Burnet, ela, por enfatizar a apódose, evidenciaria a determinação e a vontade com que as Leis argumentam (PLATO, 1979, pp. 282).

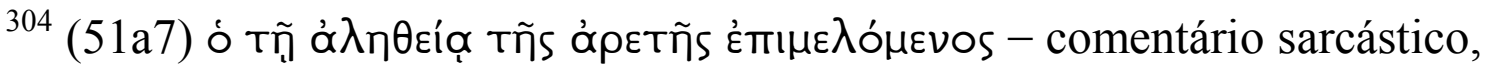
pois cuidar da ápetì era a pedra angular da missão de Sócrates (PLATO, 2001a, pp. 79). 


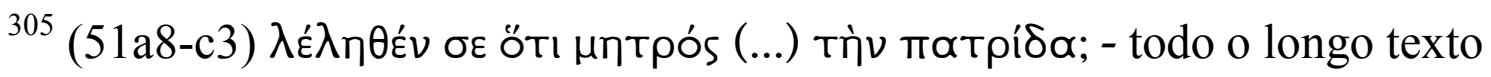

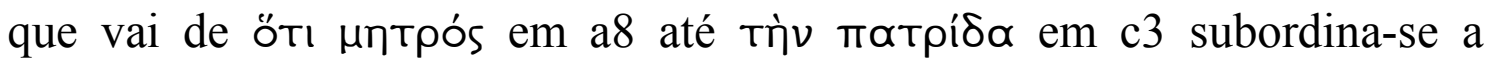
$\lambda \varepsilon \dot{\lambda} \eta \boxminus \varepsilon^{\prime} v$ e faz parte da mesma questão.

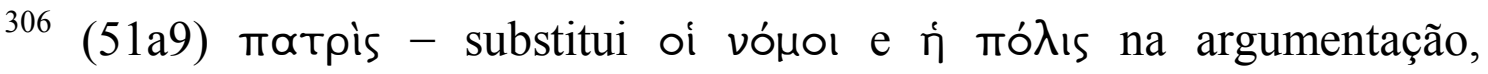
abandonando a persuasão de cunho sócio-jurídico em favor de um

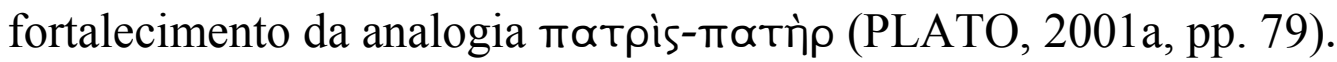

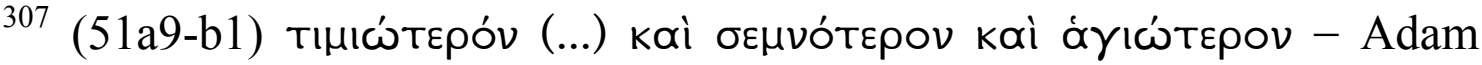
nota que os adjetivos estão dispostos em ordem crescente de importância. O primeiro é aplicável aos homens; o segundo, também aos deuses; o terceiro é restrito aos deuses (PLATO, 1997a, pp. 67). Seguindo a sugestão de Adam, uma tradução que manteria esta mesma gradação em português seria 'precioso', 'venerável' e 'sagrado'. O respeito devido às Leis e à pátria adquire um tom quase teológico (PLATO, 2001a, pp. 79).

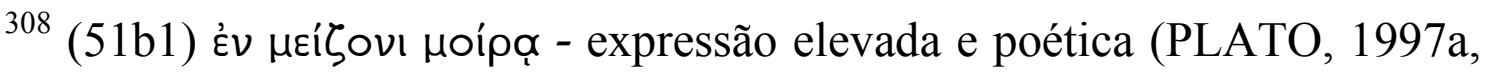
pp 67): ' que tem o maior quinhão'.

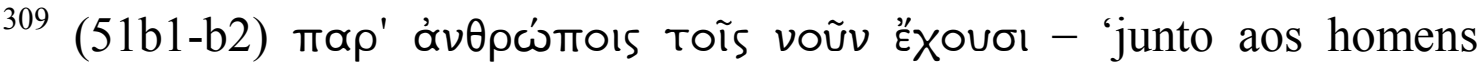
sensatos'. Ver nota $44 \mathrm{c} 7$.

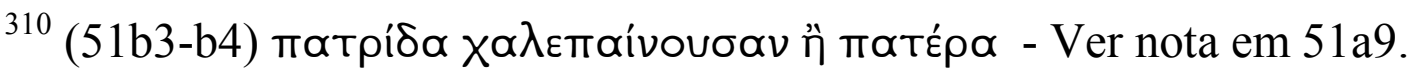

311 (51b4) $\pi \varepsilon i ́ \theta \varepsilon ı v$ - ver nota em $44 \mathrm{~b} 7$.

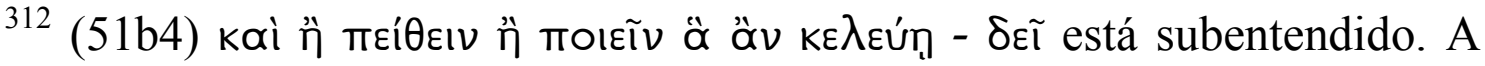
partícula àv indica que o antecedente de ö é indeterminado.

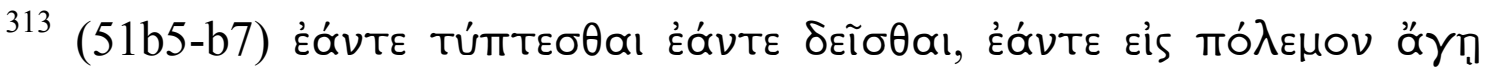

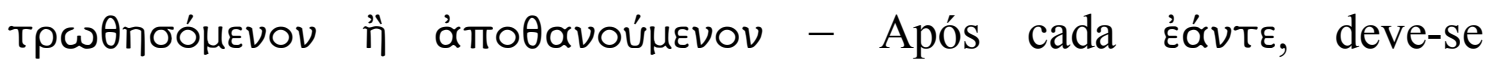
subentender mpootó tт̣̣. As três frases acompanham o crescendo visto na nota 51a9-b1

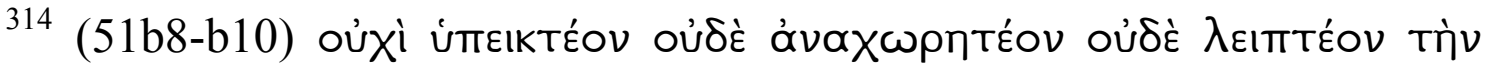

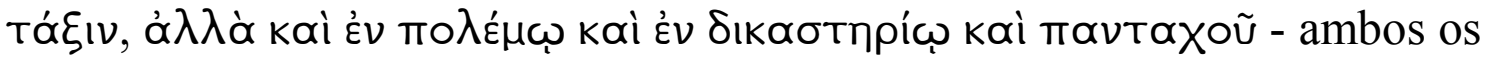


conjuntos coordenados de três fases também acompanham o crescendo visto na nota 51a9-b1. A analogia entre a obediência militar e à devida ao tribunal não era estranha a um cidadão ateniense dos séculos $\mathrm{V}$ e IV, pois os que decidiam pela guerra ou pela paz, pela condenação ou absolvição eram os mesmos que iam para guerra. No entanto, na Apologia, Ap. 28e29a, Sócrates utiliza-a para justificar sua intenção de não aceitar um hipotético acordo para que fosse absolvido na condição de que deixasse de filosofar, ou, na sua visão, de que abandonasse a missão que lhe fora confiada pelo deus.

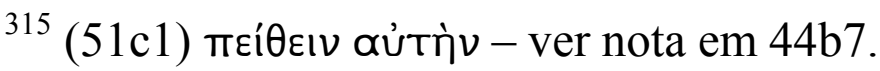

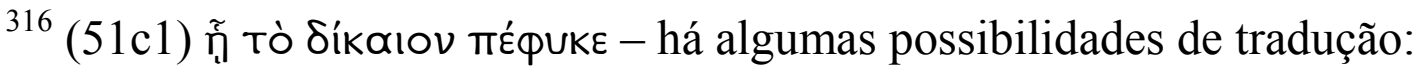

1. mostrando onde ela, a pátria, está errada.

2.

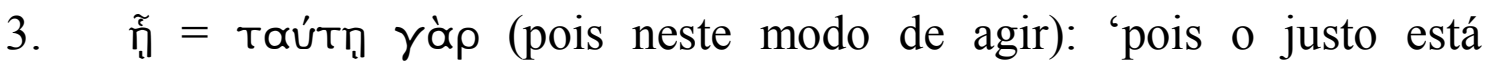
naturalmente neste modo de agir', ou seja, obedecendo-lhe ou tentando persuadi-la.

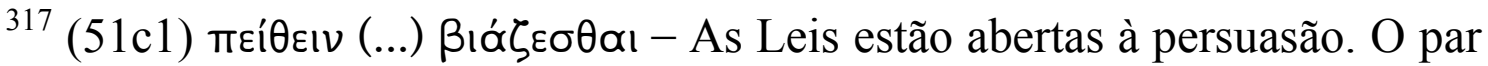
força versus persuasão era um lugar comum muito utilizado quando, entre outras coisas, os gregos queriam diferenciar-se dos não-gregos (PLATO, 2001a, pp. 80).

318 (51c6) KKómel toívuv - toívuv seguido do imperativo no diálogo introduz um novo ponto de discussão (GP, pp. 575): 'Examine agora'.

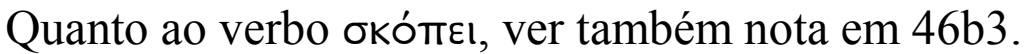

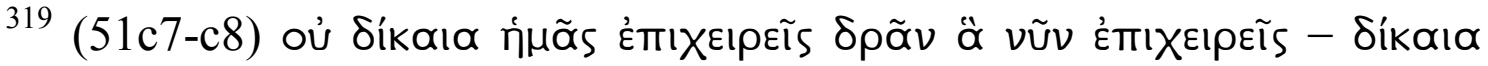
tem função predicativa. Literalmente temos algo como "você tenta fazer 
conosco ações não justas, as que você tenta fazer agora', o que seria semelhante a 'não é justo o que você tenta fazer conosco agora'.

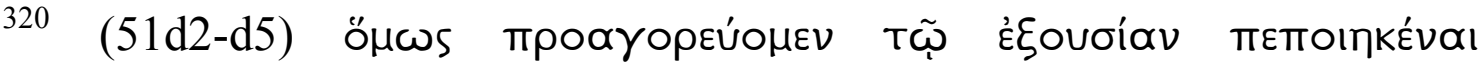

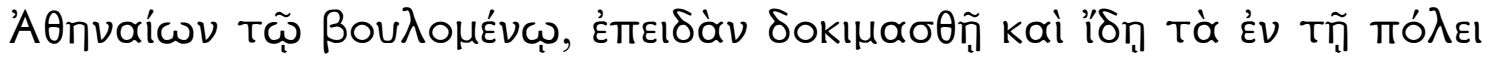

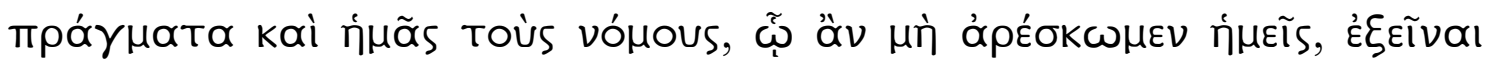

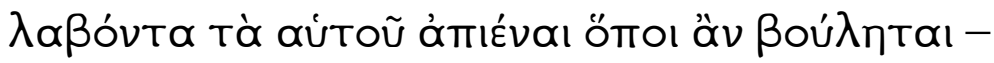

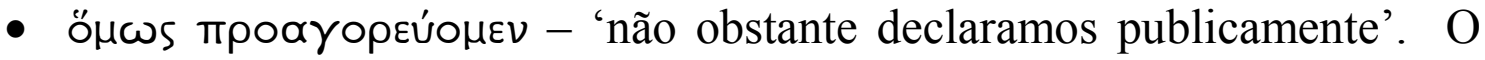
novo argumento das Leis acrescenta que, além de já estarem em um patamar diferente em relação ao cidadão, superior mesmo ao do pai com relação ao filho, houve também uma escolha da parte do efebo de continuar seguindo-as ou não quando atingisse a maioridade.

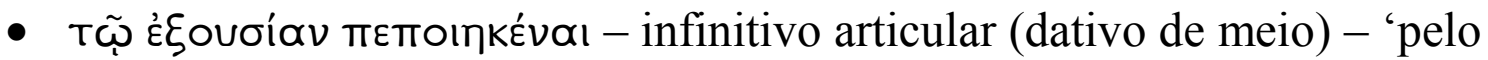
fato de termos dado permissão'

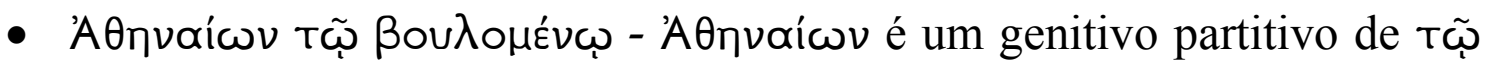

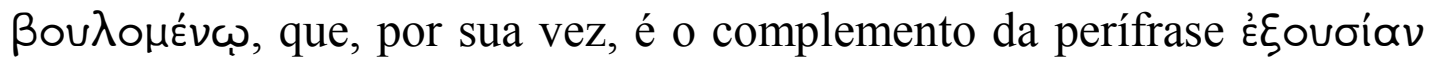

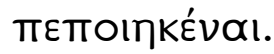

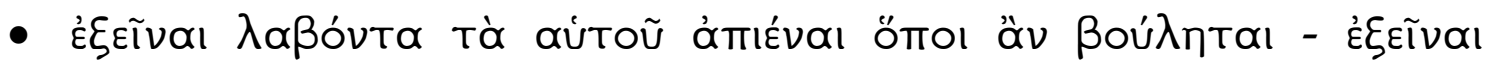

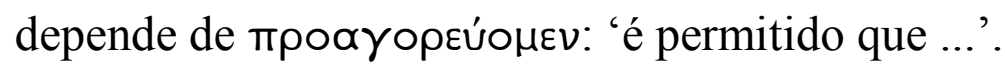

relativa cujo antecedente é indefinido.

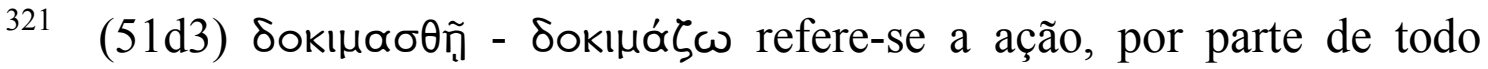
ateniense que atingia os dezoito anos e se tornava um efebo, de registrar-se no seu demo (PLATO, 1979, pp. 283).

322 (51d6) kaì - conjunção aditiva, marcando o clímax (GP, pp. 291-292): 'Além disso'. 


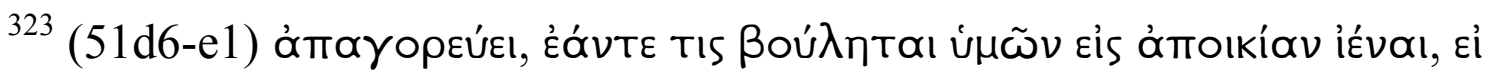

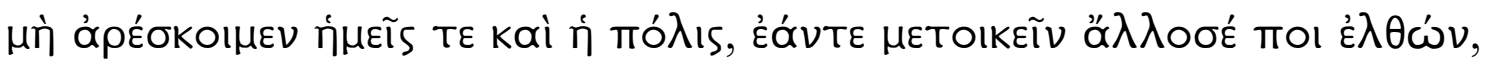

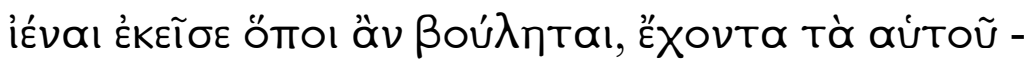

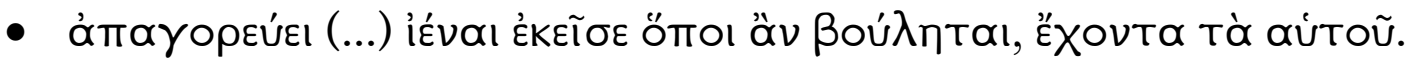

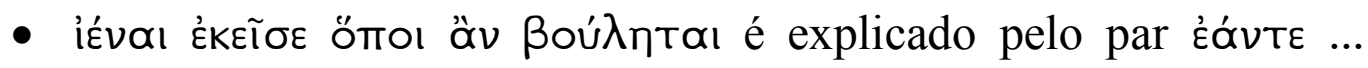
ÉớvTE (seja ... seja).

- Eis ámookíav - a uma colônia, isto é, a um lugar com vínculos com Atenas.

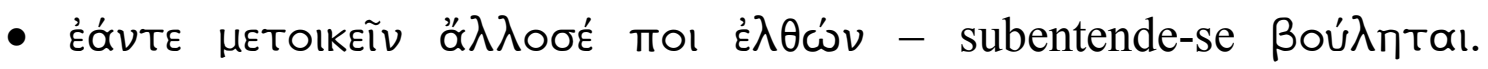

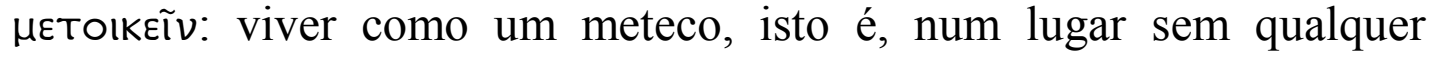

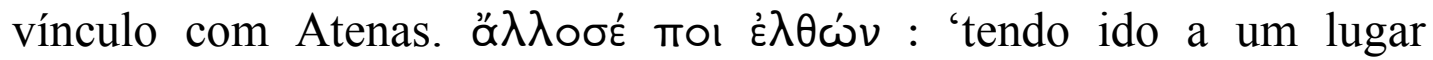
qualquer'. Literalmente: 'se quiser viver como um meteco, tendo ido a algum outro lugar'. Porém, para manter a simetria criada pelo par દ̇óvтє ... k̇óvte (seja ... seja), optei por; 'seja a outro lugar qualquer, para viver como meteco'.

${ }^{324}$ (51e2) $\delta \varepsilon ́$ - Ver nota em 48c6-c7: 'Porém'.

325 (51e4) ToũTov - retoma enfaticamente ôs $\delta^{\prime}$ ò̀ ư uñ (PLATO, 1997b, pp. 57): 'que este homem aí'.

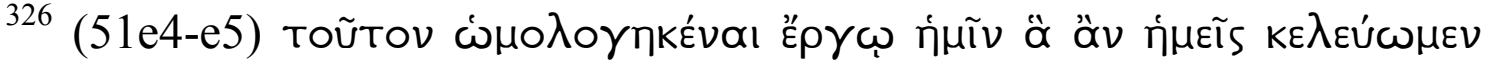

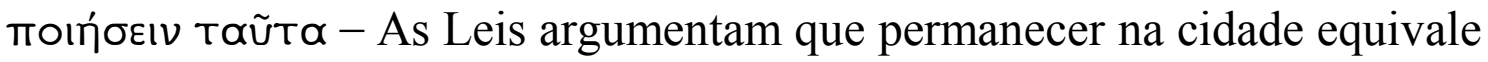
a ter concordado ipso facto, isto é, como uma conseqüência de suas ações, em fazer o que elas comandarem.

${ }^{327}$ (51e5) kaì - Ver nota em 51d6.

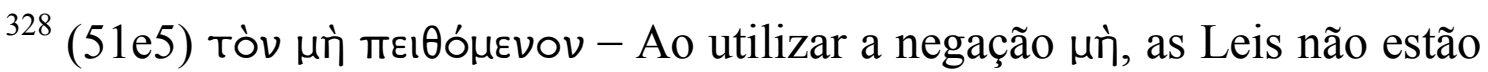
referindo-se especificamente a alguém, mas a qualquer um dos que decidiram permanecer na cidade. 


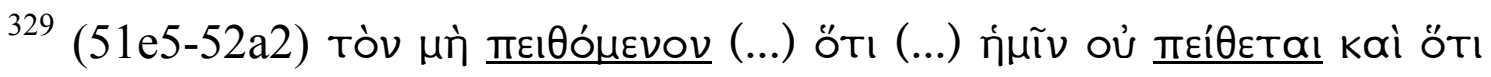

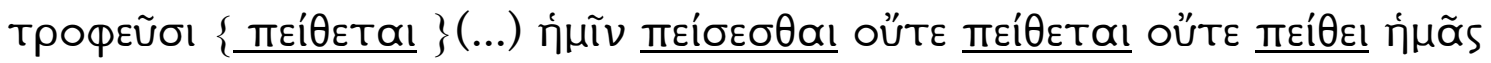

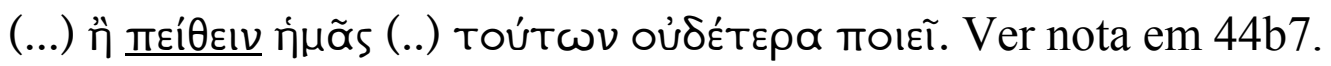

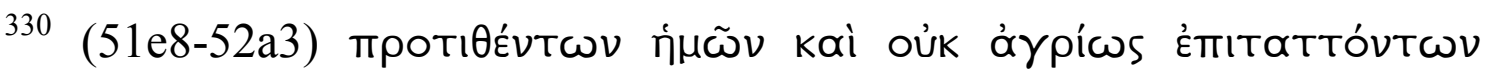

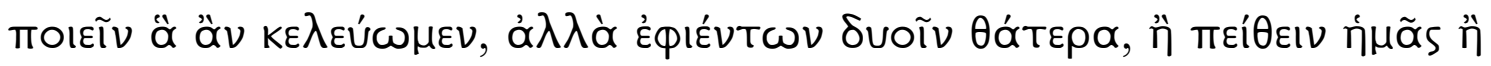

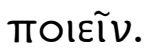

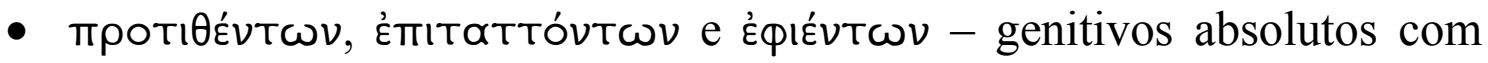
valor concessivo.

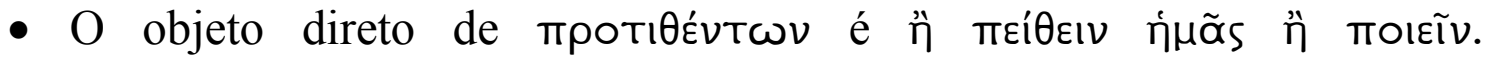

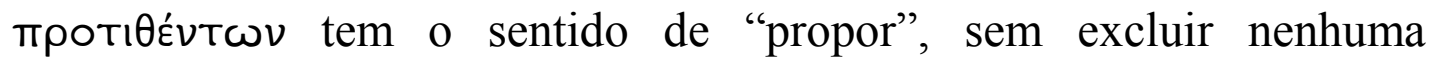
alternativa.

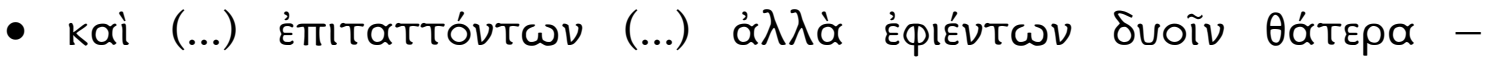

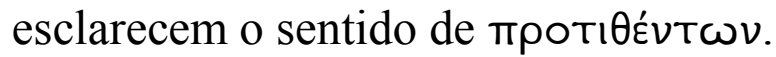

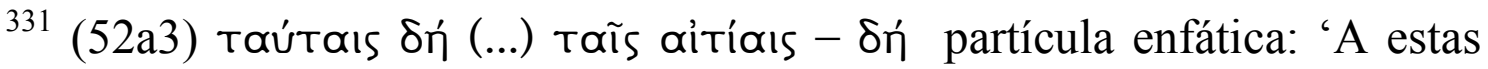
acusações ...'

332 (52a5) દ̇v Toĩs - ver nota em 43c7: 'mais do que a maioria'.

333 (52a7) દ̀v Toĩs - ver nota em $43 \mathrm{c} 7$.

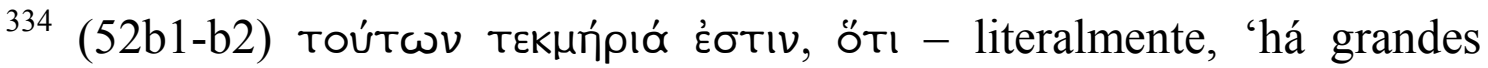
indícios disso, de que (...)'. A oração introduzida por ötı é o aposto de

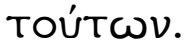

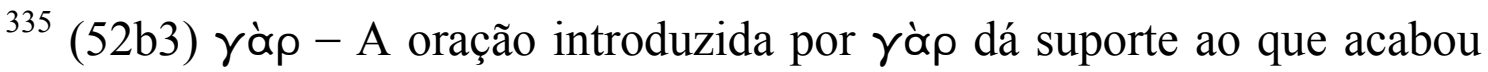
de ser afirmado com o argumento de que, se aquilo fosse falso, algo reconhecido como verdadeiro seria também falso [(GP, pp. 62-63) \& (PLATO, 1997b, pp. 59)]: 'pois, de outro modo'.

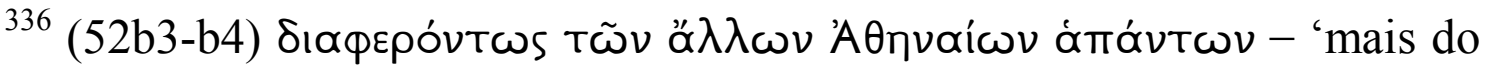
que os outros atenienses' (PLATO, 1997a, pp. 71). 


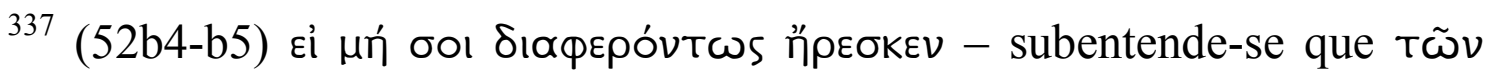

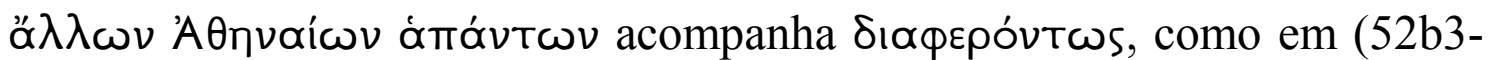
b4). Escolhi a tradução 'se você não estivesse mais satisfeito com ela que todos os demais' para o trecho em questão, ao invés do mais óbvio 'se ela não lhe agradasse mais que aos demais', para evitar uma ambigüidade que o verbo 'agradar' introduziria - e que não existe no grego. Nesta versão, poder-se-ia entender que a cidade fez mais por Sócrates do que pelos demais, quando, na verdade, a cidade ofereceu a todos o mesmo. Foi Sócrates quem se sentiu mais satisfeito com o que lhe foi oferecido.

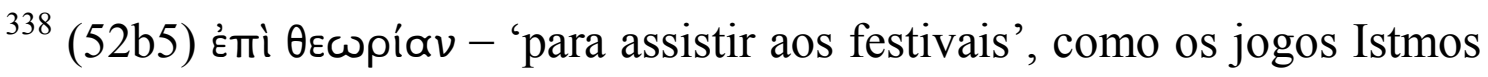
(PLATO, 1997b, pp. 59).

${ }^{339}$ (52b6) öTı $\mu$ 门̀ construído sem verbo, tem o sentido de 'exceto', 'salvo' (BIZOS, pp. 166).

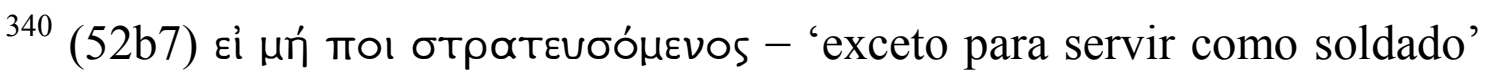
(PLATO, 1979, pp. 285).

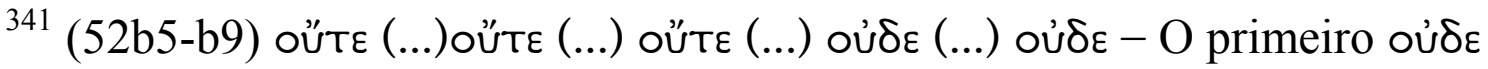
adiciona uma nova idéia com sentido negativo à seqüência de oúte (GG, sec 2949). O segundo informa que esta idéia negativa é formada pelo par

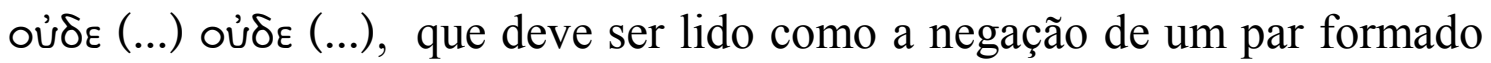
por kaì (...) kaì (...) (GG, sec 2937): ‘nem ... nem ... nem ... e, além disso, (...) não'.

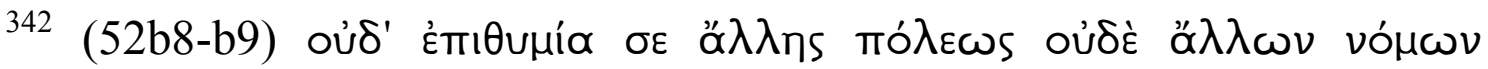

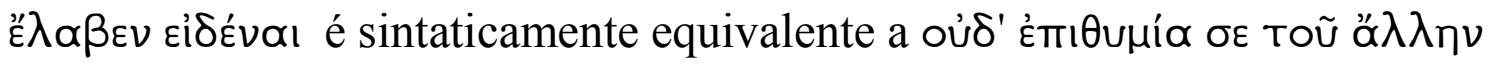

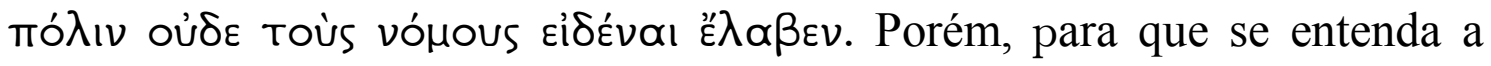
construção utilizada por Platão, algumas explicações são necessárias: 


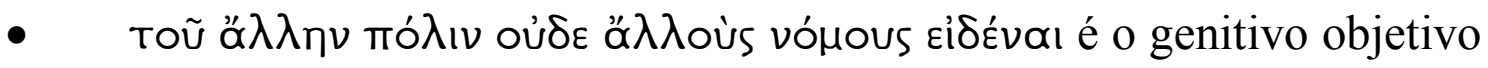

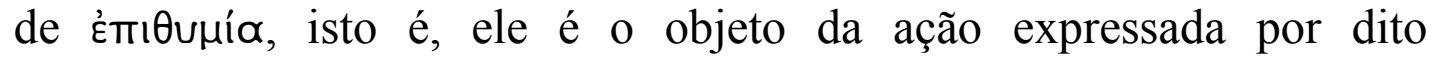
substantivo (GG, sec. 1328a).

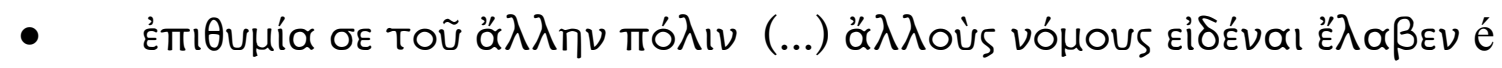

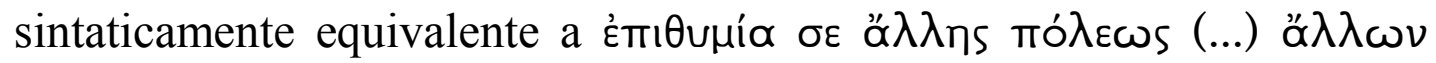

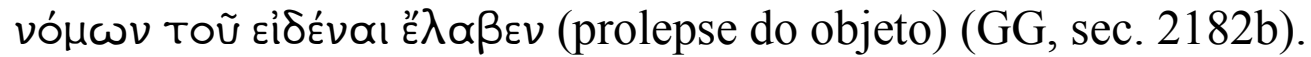

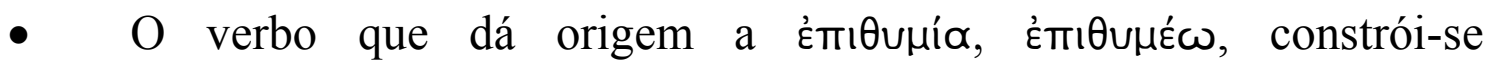
regularmente com o infinitivo.

- $\quad$ Sempre que uma palavra governe um dativo ou genitivo de um

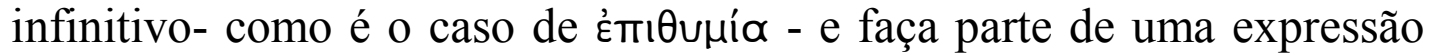
que seja equivalente a um verbo que regularmente se constrói com

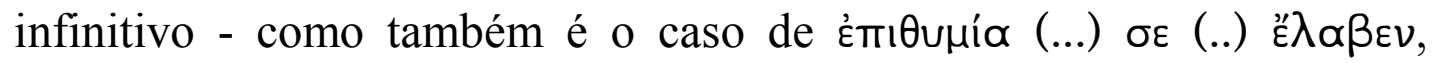

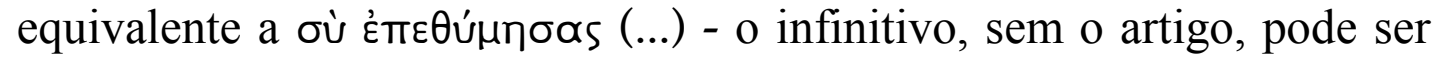

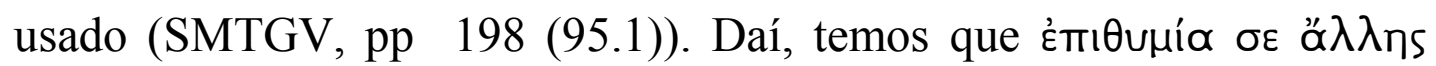

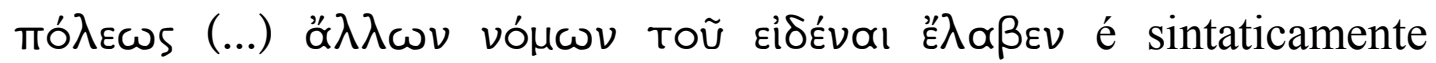

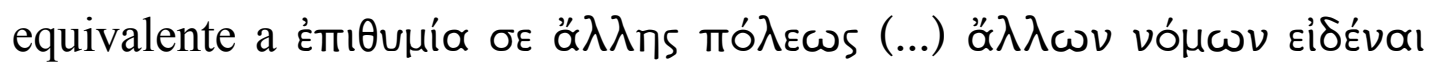

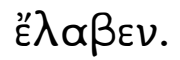

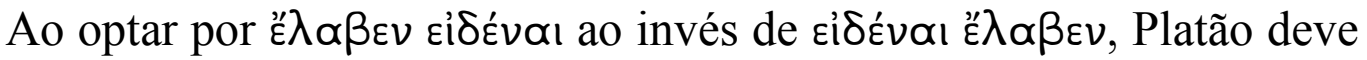
provavelmente ter desejado causar algum efeito nos seus primeiros leitores,

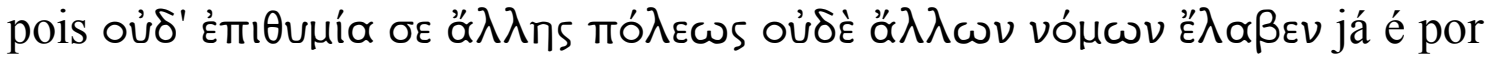
si só uma frase que faz sentido dentro das circunstâncias do diálogo - 'o desejo de outra cidade ou de outras leis não o tomou' - ainda mais quando se tem em conta que são as Leis, personificadas, que estão falando. $\mathrm{O}$ infinitivo عỉ́ćvaı apareceria em seguida, então, quase como uma correção ou explicação do sentido que a construção utilizada tinha acabado de sugerir (PLATO, 1997b, pp. 60). Resolvi manter na tradução a figura de 
sintaxe utilizada por Platão, o hipérbato: 'não o tomou o desejo de outra cidade ou de outras leis, de conhecê-las'.

Segundo Denniston, a principal função do hipérbato seria a seguinte: " The fifth motive - emphasis - seems to be far more important than the rest. Logically connected words stand out in higher relief when spatially separated: and, looking at the clause or sentence as whole, alternating rise and fall of emphasis produce a pleasing effect. To this motive we must add two others: a desire to bind the clause into a compact unit, and, in the case of Plato, a love of pattern-weaving for its own sake" (DENNISTON, 2002, pp. 58-59).

343 (52b9) à $\lambda \lambda \lambda_{\alpha}$ - ver nota em 43b1: 'ao contrário (...)'.

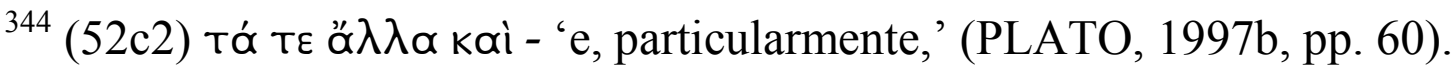

345 (52c3) ஸ́s - ver nota em 44b10: '(...), a seu ver, (...)'.

346 (52c4) हैTı Toívuv - introduz um novo item em uma série: 'e ainda' (GP, pp. 576).

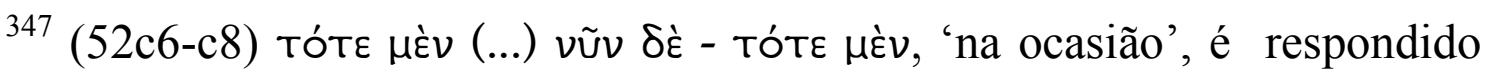
por $\nu \tilde{v} \nu \delta \dot{\varepsilon}$, 'mas agora'.

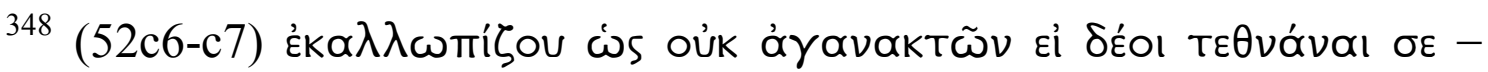
possível alusão a Apologia (Ap. 37c-38a). $\kappa \alpha \lambda \lambda \omega \pi i \zeta \omega$ constrói-se aqui como um verbo expressando sentimento ou maneira de ser (BIZOS, pp.143-144), com ஸ́s seguido de um particípio.

${ }^{349}$ (52c7) à่ $\lambda \lambda \grave{\alpha}$ - ver nota em 49d4: 'e'.

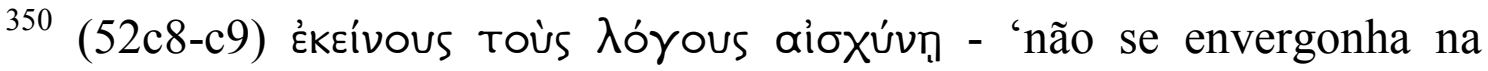

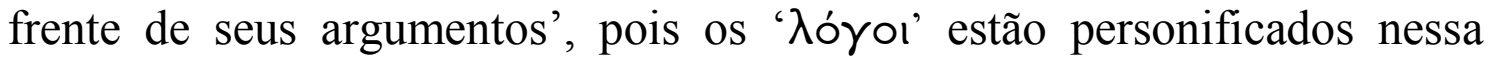
passagem (PLATO, 1997a, pp. 72).

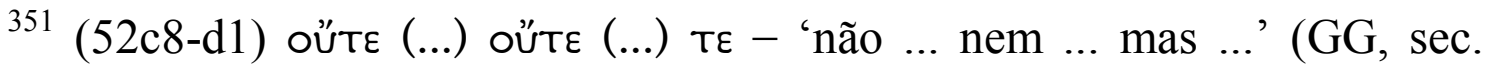
2945). 


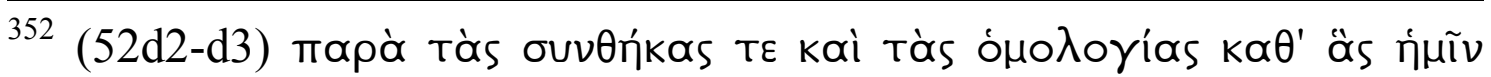

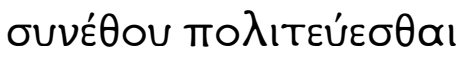

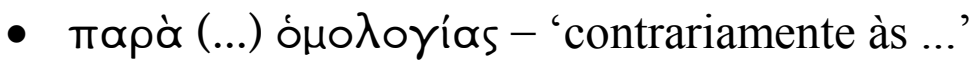

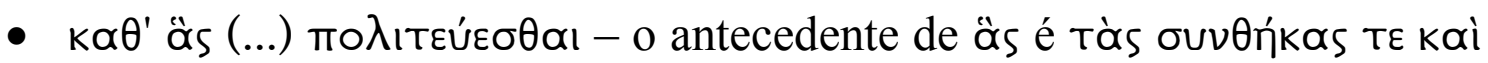

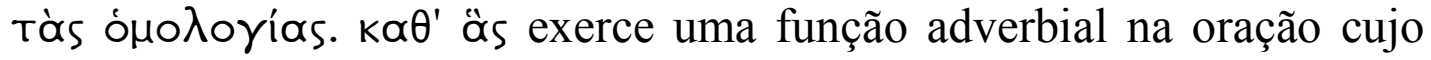

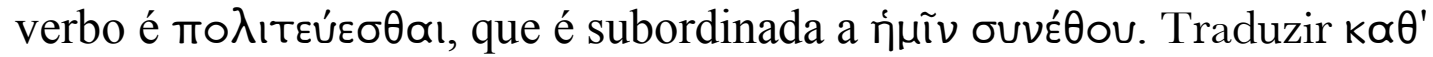

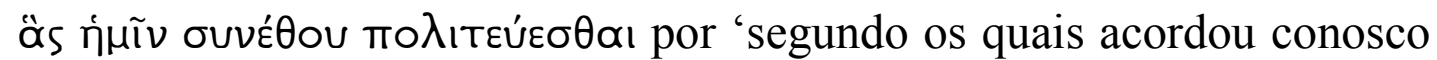
viver como cidadão', deixa 'segundo os quais' sem função sintática na oração que a introduz, como no grego, o que é pouco usual em português, mas não incorreto.

353 (52d4) $\mu \varepsilon \dot{v}$ ỡv - marca a transição para um novo argumento (GP, pp. 472): 'então'.

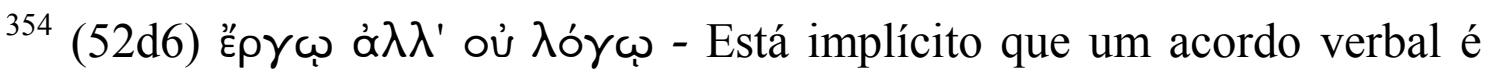
menos comprometedor que aquele no qual as ações tomam o lugar das palavras (PLATO, 1997a, pp. 73). à $\lambda \lambda{ }^{\alpha}$ marca uma forte oposição entre os dois termos, como em 43b1. Assim a melhor forma de traduzir tal

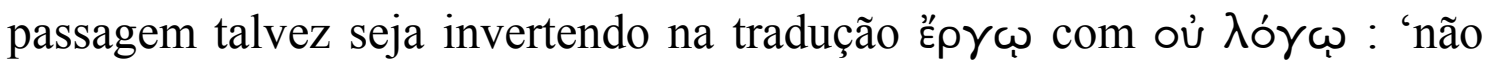
com palavras, mas por seus atos'.

${ }^{355}(52 \mathrm{~d} 7) \stackrel{\alpha}{\alpha} \lambda \lambda \mathrm{T} \mathrm{TI}$ ก̀ - Ver nota em 50a9.

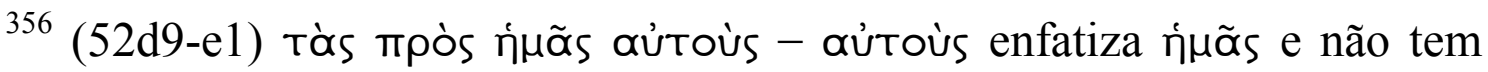
sentido reflexivo (PLATO, 1997a, pp. 73): 'especificamente conosco'.

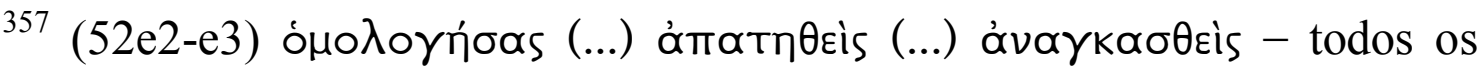
particípios introduzem orações adverbiais cujo sentido é concessivo.

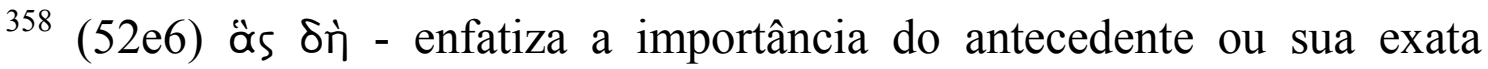
identificação com o conseqüente (GP, pp. 218-219): 'aquelas mesmas que'. 


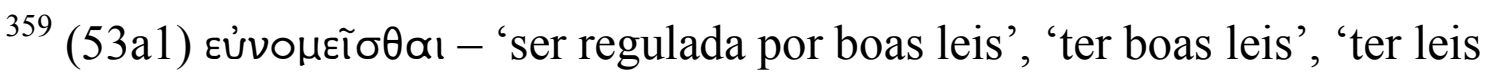
bem estabelecidas' (PLATO, 1997b, pp.61). Segundo Xenofonte, Sócrates era admirador da obediência espartana às leis (Mem. IV.4.15). Adam cita

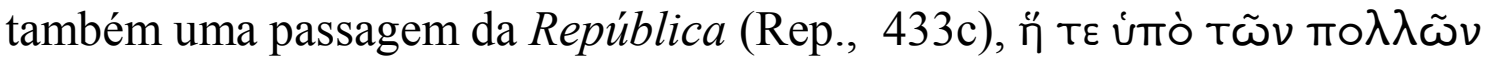

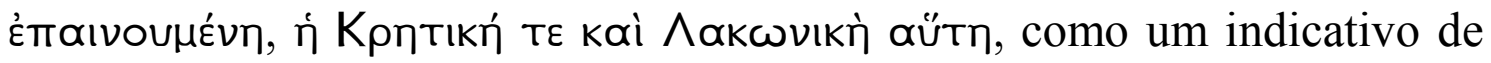
que Sócrates possa realmente ter tido tal opinião (PLATO, 1997a, pp.73). ${ }^{360}$ (53a2) à $\lambda \lambda \grave{\alpha}^{2}$ - Ver nota em 46b8: 'mas, pelo contrário,'

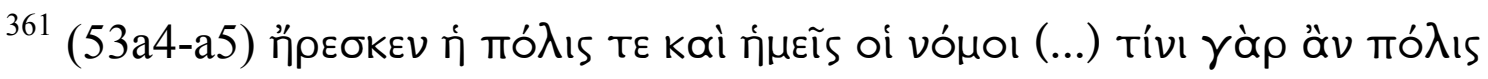

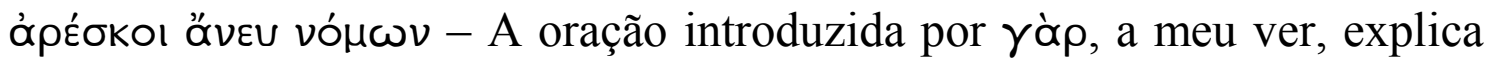

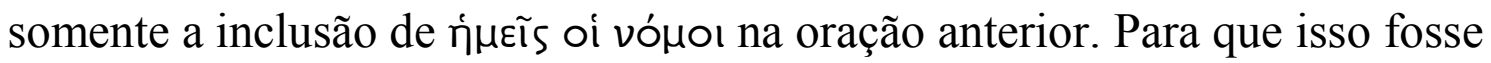
enfatizado na tradução utilizei na tradução o advérbio 'também', inexistente no original em grego.

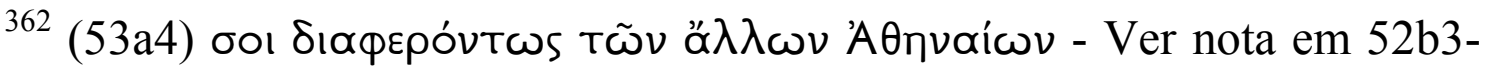
b4.

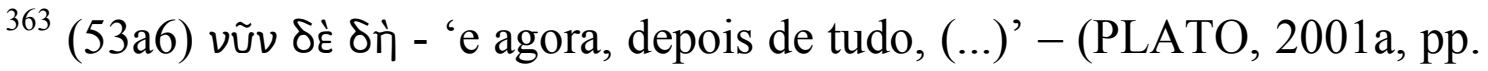
$85)$.

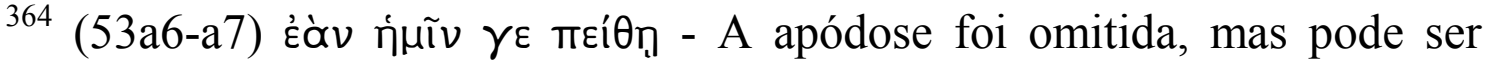

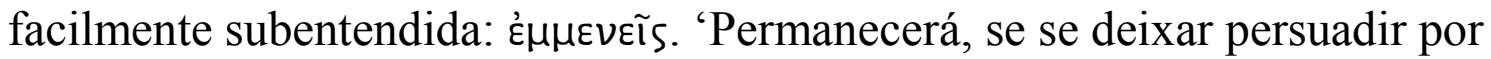
nós, Sócrates'. Ver também nota em 44b7.

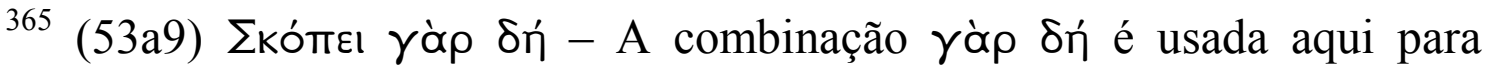
prender a atenção do ouvinte (GP, pp. 243) além de estabelecer uma conexão entre o que segue e o argumento anterior, mais precisamente, explicando as diversas formas pelas quais Sócrates parecerá ridículo aos olhos de seus concidadãos [(PLATO, 1979, pp. 288) e (PLATO, 2001a, pp. 86)]: 'examine com atenção'. Quanto ao verbo бкóтєє, ver também nota em $46 \mathrm{~b} 3$. 


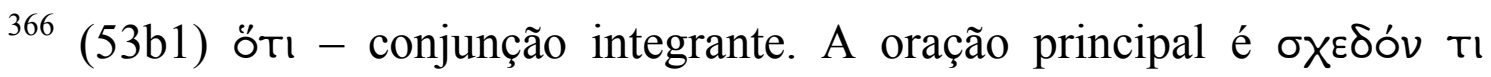
$\delta \tilde{n} \lambda$ ov ötı.

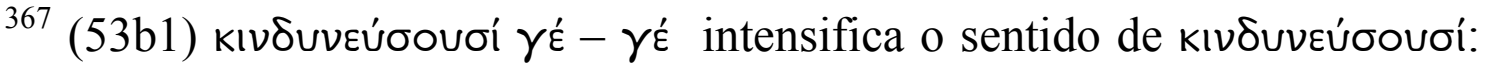
'estarão expostos a riscos: ao risco de ...' (PLATO, 1997b, pp. 62).

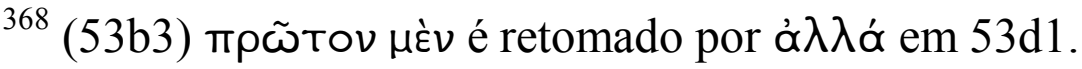

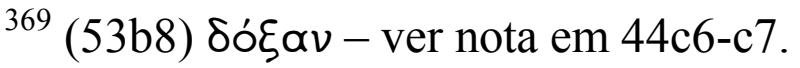

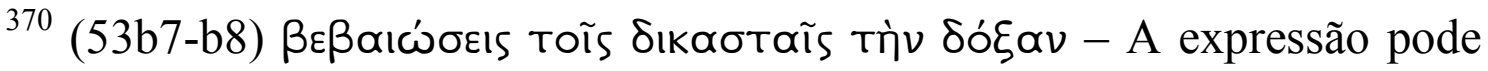
tanto significar 'confirmará o juízo dos juizes' quanto 'confirmará o juízos das outras pessoas com relação aos juizes'. A primeira interpretação tem sido preferida pelos comentadores, em particular por Burnet, pela própria seqüência do texto. 'The judges will feel assured that they were right in finding Socrates guilty of corrupting the young, since one who corrupts the law will a fortiori be in all probability a corruptor of the youth' (PLATO, 1979, pp. 288).

${ }^{371}$ (53c2) $\nu \varepsilon ́ \omega \nu ~ \gamma \varepsilon$ - A partícula realça a preocupação com os mais jovens e remete-nos diretamente à acusação feita contra Sócrates, descrita em sua

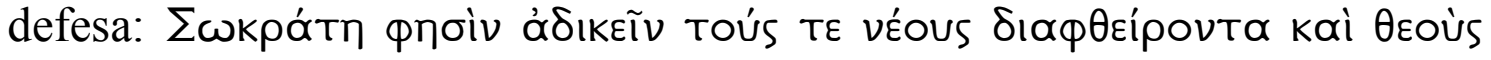

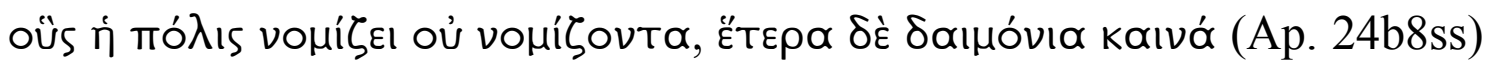
(PLATO, 1997b, pp. 63).

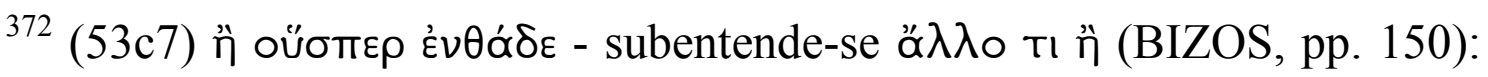
'Seriam exatamente os daqui (...)?'.

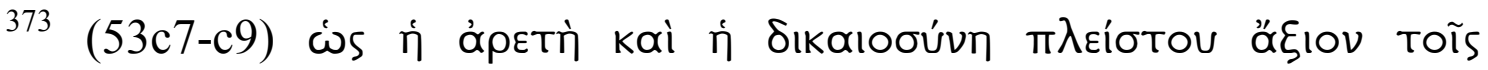

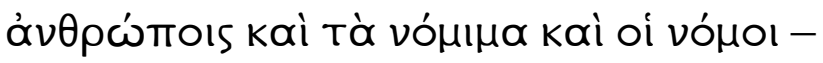

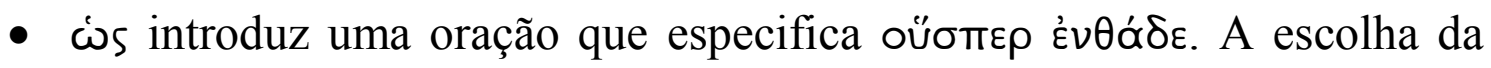
conjunção ஸ́s - em detrimento de ötı (BIZOS, pp. 129) implica uma atitude de dúvida das Leis com relação ao que será dito: 'dizendo que, a seu ver, (...)'. 


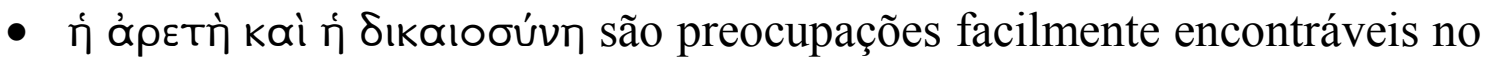
Sócrates dos diálogos de Platão, sendo o mais famoso exemplo o de sua defesa, (Ap. 30a-b) (Ver nota em 45d8-d9).

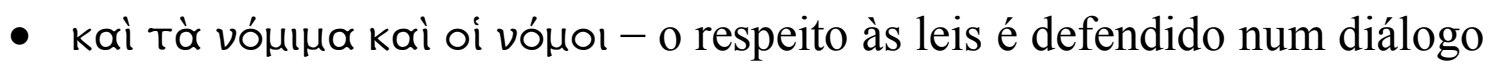
tardio de Platão, o Político (297d-303d).

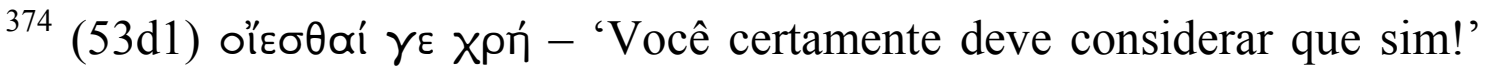
(PLATO, 2001a, pp. 88).

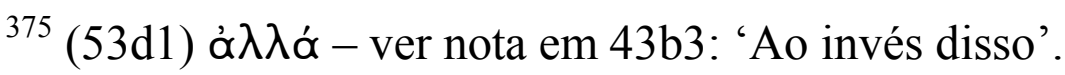

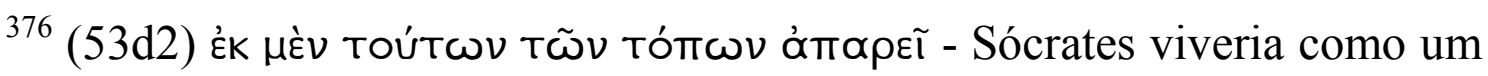
exilado, conforme previu na sua defesa (Ap. 37d). Ver nota em $45 \mathrm{~b} 7$.

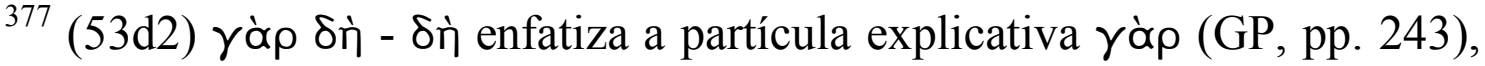
mostrando confiança no fato que será dito (PLATO, 1997b, pp 64): 'porque, sem dúvida, (...)'.

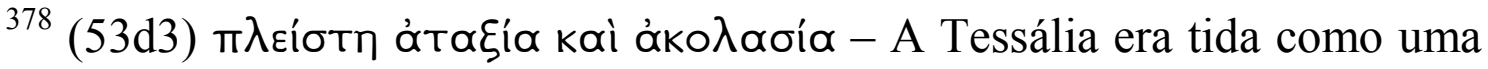
exemplo claro de governo não constitucional por Xenofonte (Mem. 1.2.24). (PLATO, 2001a, pp. 88).

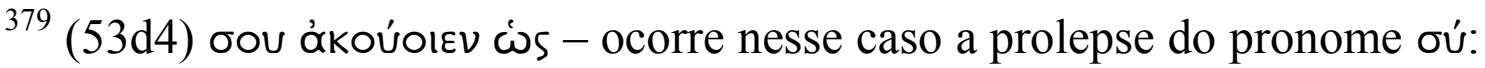
'ouviriam como você (...)'.

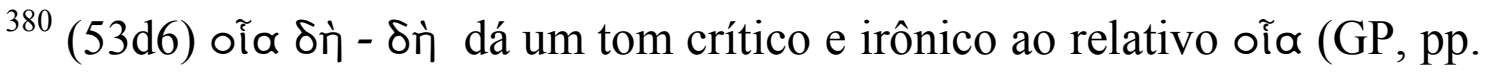
220).

381 (53d8) öTı - conjunção integrante. A oração principal é ös દ́pعĩ em 53e2.

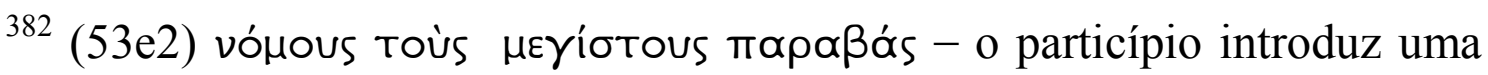
oração consecutiva.

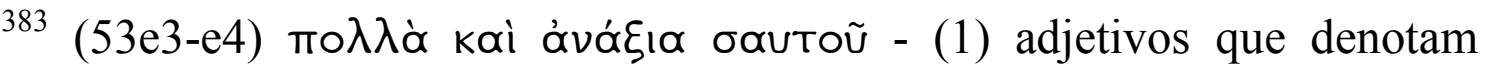
quantidade são freqüentemente ligados a outro adjetivo na mesma construção por kaì (GG, sec 2879). Em português, a conjunção é

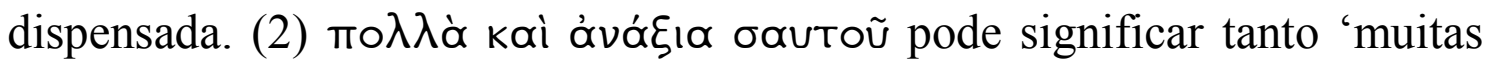


coisas não merecidas por você' quanto 'muitas coisas indignas ao seu respeito'. Optei, então, diferentemente da maioria das traduções consultadas, por manter esta ambigüidade em português, traduzindo a expressão como 'muitas coisas indignas de você'.

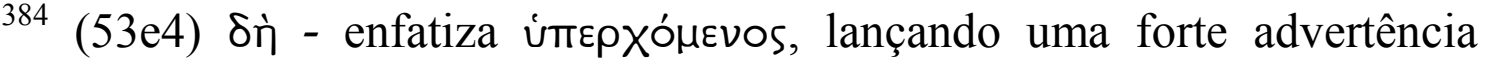
(PLATO, 1997b, pp. 64): 'certamente'.

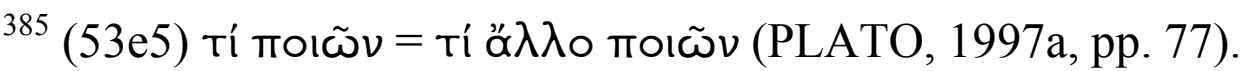

${ }^{386}$ (54a2) ท่นĨv - dativo ético (PLATO, 1927, pp. 55), usado para mostrar ou assegurar o interesse de quem fala sobre aquilo de que fala. Smith sugere que, em inglês, este estilo familiar de conversação dado pelo dativo ético pode ser emulado com expressões do tipo '(...), I beg you, (...)', '(...), please, (...)', ‘(...), you know, (...)’ etc (GG, sec. 1486). Em português, pode-se utilizar a seguinte sonstrução: ' (...), perguntamos, (...)'.

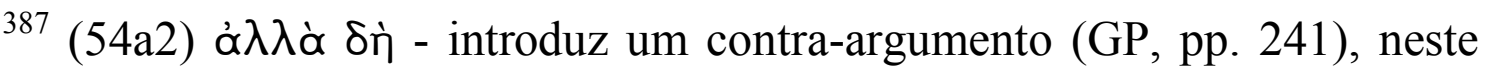
caso, respondendo ao argumento de Críton em 45c10-d6 de que Sócrates, ao recusar-se a fugir, estaria abandonando seus filhos: 'Ora, mas você dirá certamente que (...)'.

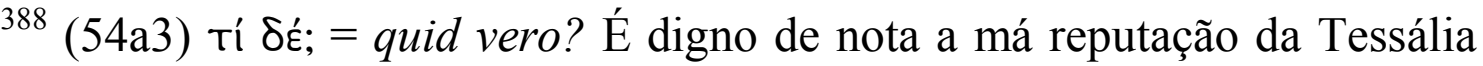
(PLATO, 1997a, pp. 78): 'Você fala sério?'

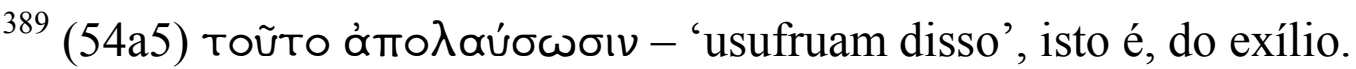

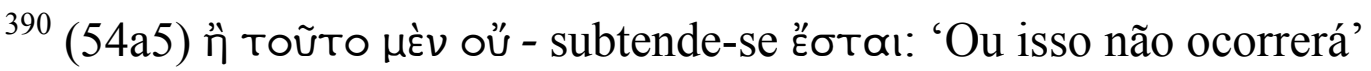

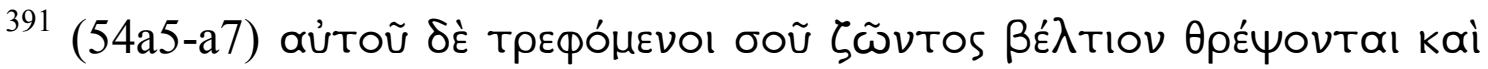

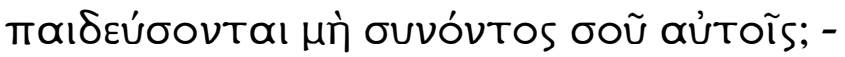

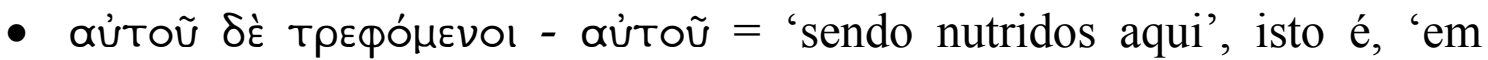
Atenas' (PLATO, 1997b, pp. 65).

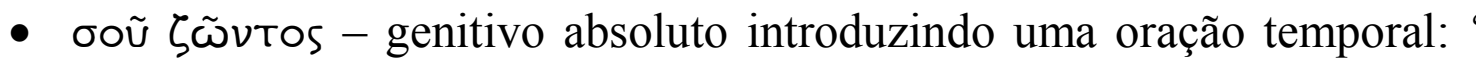
enquanto você vive'. 


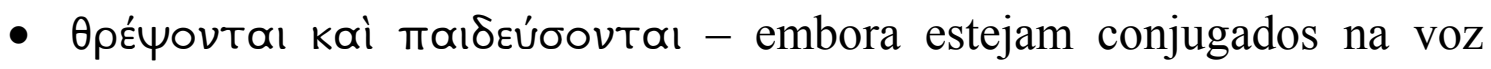
média, ambos os verbos têm sentido passivo.

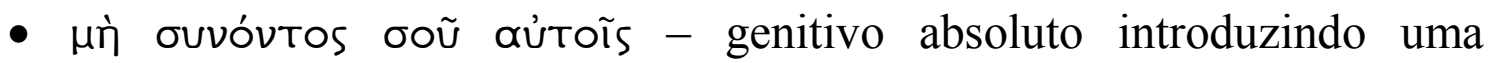
condição, daí o uso de $\mu$ ท̀: 'sem que você esteja com eles'.

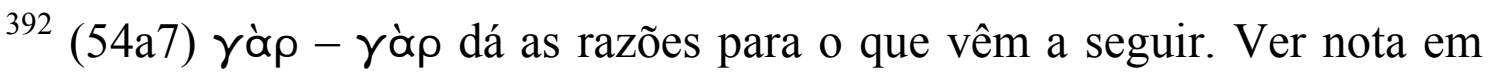
44e6: 'Sim, eles serão, pois (...)'

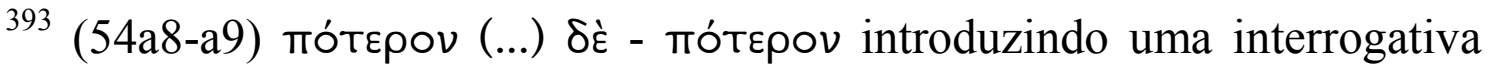
disjuntiva onde uma das alternativas foi omitida por poder ser subentendida ( ... ou não é nada disso?).

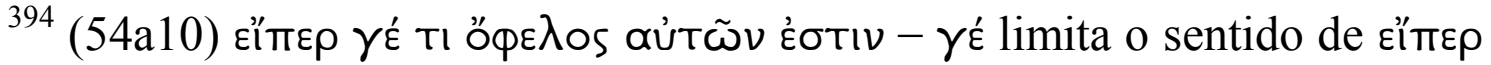
('se realmente'): 'Se, ao menos, há realmente alguma utilidade para (...)'.

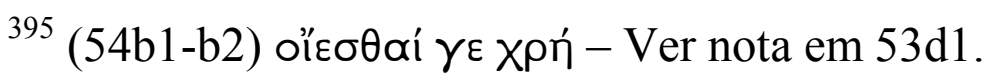

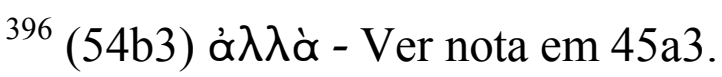

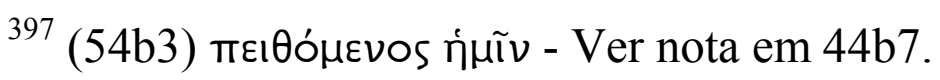
398 (54b7) таũTa - refere-se à proposta de Críton. Acrescentei o aposto, 'o proposto por Críton', para dar clareza ao texto.

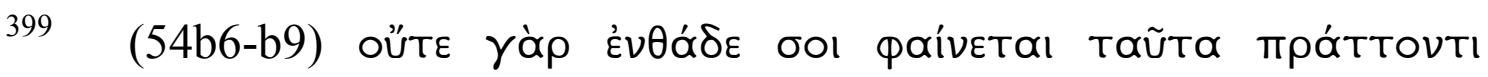

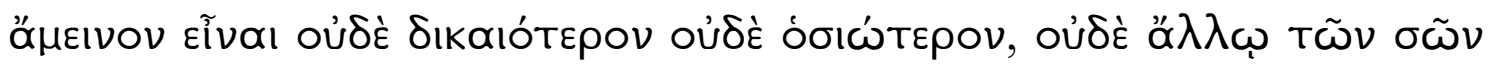

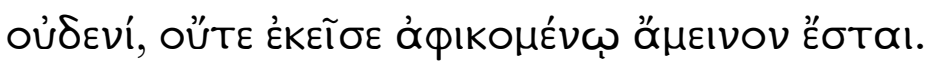

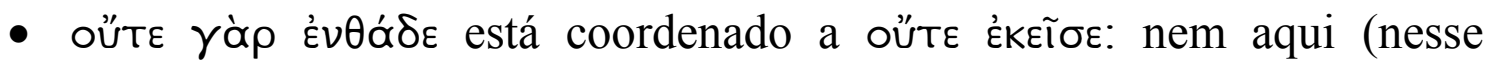
mundo) ... nem lá (no outro).

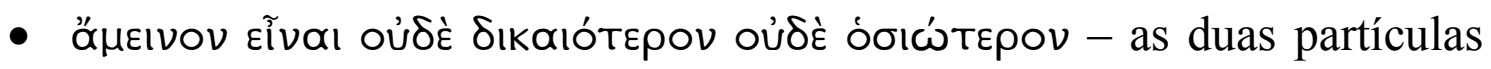

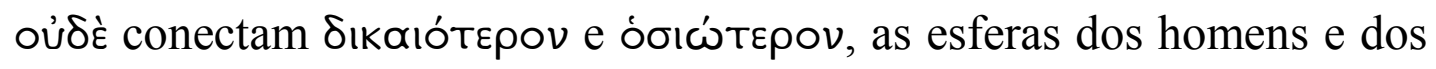

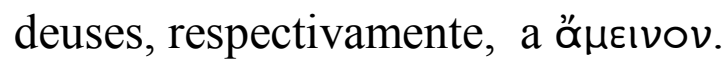

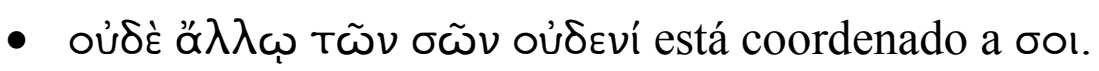

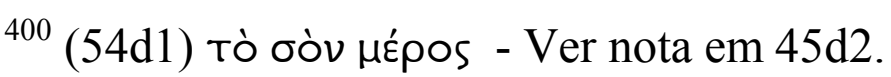




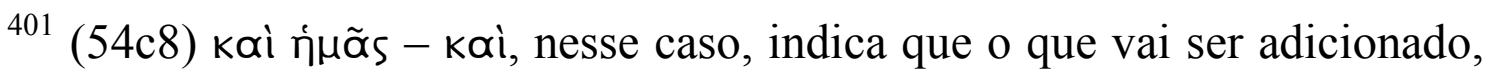
ìuãs, é de difícil aceitação (GP, pp. 293).

402 (54d1) ’̀ $\lambda \lambda \grave{\alpha}-$ Ver nota em 43d7: 'Bem, tomara que (...)'.

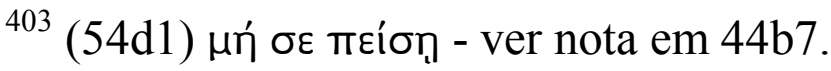

${ }^{404}$ (54d4-d5) Os coribantes eram os sacerdotes da deusa Cibele, que, durantes as cerimônias em honra da deusa, dançavam desvairadamente, soltanto gritos estridentes e tocando flautas. Burnet acrescenta que os coribantes costumavam ouvir os sons das flautas mesmo quando já tinham parado de tocá-las (PLATO, 1979, pp. 291-292).

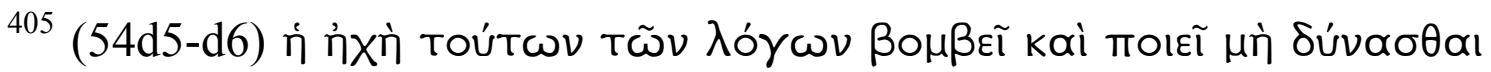

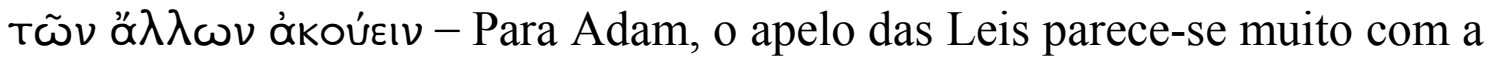

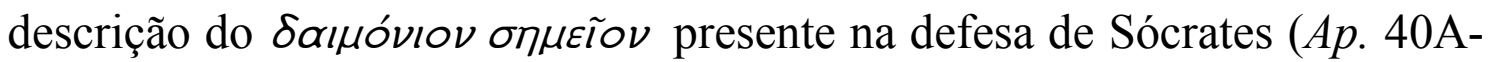
B), devendo, assim, ser interpretado como tal (PLATO, 1997a, pp. 80).

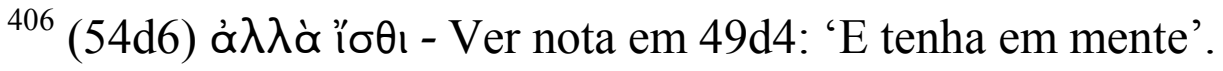

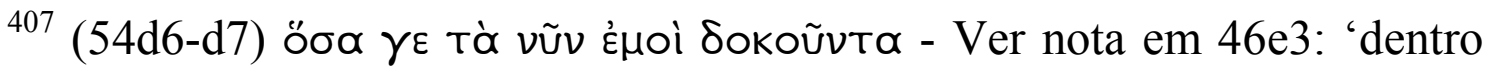
do que são meus julgamentos agora'.

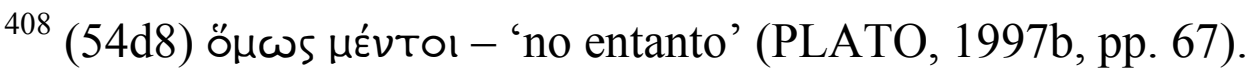




\section{Referências}

\section{Edições e traduções}

PLATÃO. Apologia de Sócrates precedido de Sobre a Piedade (Eutífron) e seguido de Sobre o Dever (Críton). Porto Alegre: L\&PM Editores, introdução, tradução do grego e notas de André Malta Campos, 2008. PLATÃO. Apologia de Sócrates e Críton. Lisboa: Edições 70, introduções tradução do grego e notas de Manuel de Oliveira Pulquério, $2^{\mathrm{a}}$ ed., 2002. PLATO. Euthyphro, Apology of Socrates and Crito. Oxford: Oxford University Press, edited with notes by John Burnet, $1^{\text {a }}$ ed., 1979

. Crito. London: Bristol Classical Press, edited with introduction, notes and vocabulary by J. Adam. (1a ed 1888), 1997 a.

- A Greek Prose Reading Course for Post-Beginners. Unit 2.

Philosophy. Plato: Crito: London:Bristol Classical Press, with commentary and vocabulary by Malcolm Campbell, 1997b

. The Martyrdom of Socrates (Apology \& Crito with selections from Phaedo, partly in the original and partly in translation). London: Bristol Classical Press, edited with introduction, vocabulary and note by F.CV. Doherty.

. Platonis Opera. Tomus I. New York, Oxford University Press, recognoverunt brevique adnotatione critica instruxerunt: E. A Duke. W. F. Hicken, W.S. M. Nicoll, D. B. Robinson, J.C. G. Stratchan, 1995

. Plato Apology of Socrates and Crito, with Extracts from the Phaedo and Symposium and from Xenophon's Memorabilia. Boston: College Series of Greek authors, edited by Louis Dyer and revised by Thomas Day Seymour, $2^{\mathrm{a}}$ ed, 1998 
. Crito. London: Bristol Classical Press, edited with commentary and vocabulary by Chris Emlyn-Jones, $1^{\text {a }}$ ed., 2001a

. Euthyphro, Apology, Crito, Phaedo and Phaedrus. Cambridge, Massachusets: Harward University Press \& London, St Edmundsbury Press Ltd, with an english translation by Harold North Fowler, 2001b (Loeb Classical Library).

. Plato: Crito: London: University Tutotial Press, edited by A. F. Watt, M. A. Oxon, 1927.

PLATON. Oeuvres complètes. Introduction, Hippias Mineur, Alcibiade, Apologie de Socrate, Euthypron, Criton. Paris: Belles Lettres, texte établi et traduit par Maurice Croiset, 2002. - Apologie de Socrate et Criton. Paris: GF Flammarion, introductions et traductions inédites de Luc Brisson, $3^{\mathrm{a}}$ ed., 2005.

\section{Estudos sobre o Críton}

ALLEN, R.E. Socrates and Legal Obligation. Minneapolis: University of Minesota Press, 1980.

KRAMER, Scott. Socrates' Dream: Crito 44a-b. The Classical Journal. Vol. 83, No. 3, pp. 193-197

STOKES, Michael. Dialectic in Action: An Examination of Plato's Crito. Swansea: The Classical Press of Wales, 2005.

WEISS, Roslyn. Socrates Dissatisfied: an analysis of Plato's Crito. New York: Oxford University Press, 1998.

WOOZLEY, A.D. Law and Obedience: the arguments of Plato's Crito. Chapel Hill: The University of North Carolina Press \& London: Duckworth, $1^{\text {a }}$ ed., 1979 


\section{Auxiliar}

DOVER, KJ. Greek Popular Morality in the time of Plato and Aristotle. Oxford: Blackwell, 1974

FINLEY, M.I. L'Invention de la Politique. Paris: Flammarion, traduit de l'anglais par Jeannie Carlier, 1995.

GRIMAL, Pierre. Dicionário da Mitologia Grega e Romana. Rio de Janeiro, Bertrand Brasil, 2000 ( $4^{\mathrm{a}}$ ed.)

IRWIN, Terence. Plato's Ethics. New York: Oxford University Press, 1995.

PALMER, F.R. Mood and Modality.New York: Cambridge University Press, 1988.

SANTAS, Gerasimos Xenophon. Socrates: Philosophy in Plato's Early Dialogues. London:Routledge \& Kegan Paul, 1979.

VLASTOS, Gregory. Socrates, Plato and their tradition. Princeton, New Jersey: Princeton University Press, edited by Daniel W. Graham, 1995a. . Socratic Studies. New York: Cambridge University

Press, $1995 b$

. Socrates: Ironist and Moral Philosopher. New York:

Cornnell University Press, 1991.

\section{Gramáticas e dicionários}

BAILLY, A. Dictionnaire Grec-Français. Paris: Hachette, 2000.

BIZOS, M. Syntaxe Grecque. Paris: Vuibert, 2002. 
CHANTRAINE, P. Dictionnaire Étymologique de la Langue Grecque: Histoire des mots. Paris: Klincksieck, 1999.

DENNISTON, J. D. Greek Prose Style. London: Duckworth, 2002. . Greek Particles. London: Duckworth, 1996.

DOVER, K. J. Greek Word Order. London: Duckworth, 2001. ÉDOUARD des PLACES, S. J.. Lexique de la Langue Philosophique de Platon. Paris: Les Belles Lettres, 2003

GOODWIN, W. W. Syntax of the Moods and Tenses of the Greek Verb. Boston: Ginn Brothers, 6a ed., 1875. . A Greek Grammar. New York: St. Martins Press, 1968. HUMERT, J. Syntaxe Grecque. Paris: Klincksieck, 1999. LIDELL, H.G. \& SCOTT, R. A Greek English Lexicon with a revised supplement. New York: Oxford University Press, 1996.

RAGON, E. Grammaire Grecque. Paris: De Gigord, 40a ed., 2001. SMYTH, H. W. Greek Grammar. New York: Harvard University Press, 1984. 
Anexo I - Texto do Críton em grego 